\title{
Isolierung und Charakterisierung des testisspezifisch exprimierten Gens HASH der Maus
}

\author{
Dissertation \\ zur Erlangung des Doktorgrades \\ der Mathematisch-Naturwissenschaftlichen Fakultäten \\ der Georg-August-Universität zu Göttingen
}

\author{
vorgelegt von \\ Changkyu Oh \\ aus Hongsung, Korea
}

Göttingen 2000 
D7

Referent: $\quad$ Prof. Dr. W. Engel

Koreferent: $\quad$ Prof. Dr. U. Grossbach

Tag der mündlichen Prüfung: 27. April 2000 


\section{INHALTSVERZEICHNIS}

Inhaltsverzeichnis

Verzeichnis der Abbildungen 8

Verzeichnis der Tabellen 9

I. Einleitung 10

1. Spermatogenese und Genexpression 10

2. Das HASH-Gen 12

3. Ziele der vorliegenden Arbeit 13

II. MATERIAL UND METHODEN 14

1. Chemikalien 14

2. Gebrauchswaren 16

3. Sterilisation 17

4. Puffer und Stammlösungen 17

5. Medien, Agarplatten und Antibiotika 22

5.1. Medien für Bakterien und Phagen___ 22

5.2. Antibiotika _— 22

5.3. X-Gal-Platten __ 23

5.4. Medien für Zellkultur ___ 23

6. Verwendete Bakterienstämme, Vektoren, Gensonden, Bibliotheken und Zellinien ___ 24

6.1. Bakterienstämme____ 24

6.2. Plasmide, Phagemide und Lamda-Vektor __ 24

6.3. Synthetische Oligonukleotide ___ 25

6.4. Gensonde____ 25

6.5. Bibliotheken __ 25

6.6. Eukaryotische Zell-Linien___ 26

7. Mausstämme ___ 26

8. Standardmethoden und -reaktionen in der Molekularbiologie ___ 27

9. Methoden zur Isolierung von Nukleinsäuren __________ 27

9.1. Minipräparation von Plasmid-DNA __ 27

9.2. Plasmid-Minipräparation nach Qiagen-Protokoll ___ 28 
9.3. Maxipräparation von Plasmid-DNA 28

9.4. Maxipräparation von Plasmid-DNA über einen CsCl-Gradienten ___ 29

9.5. Isolierung von Phagen-DNA___ 30

9.6. Isolierung genomischer DNA aus Organen___ 32

9.7. Isolierung von Gesamt-RNA aus Geweben____ 32

9.8. Isolierung von Poly (A) ${ }^{+}-\mathrm{RNA}$

9.9. Konzentrationsbestimmung von DNA und RNA ___ 34

10. Enzymatische Modifikation von DNA: Klonierungstechniken____ 35

10.1. Restriktionsenzymatische Spaltung von DNA ___ 35

10.2. Dephosphorylierung von Plasmid-DNA ___ 35

10.3. Ligation eines DNA-Inserts in einen Plasmid-Vektor ___ 36

10.4. Herstellung kompetenter Bakterien für die Transformation ___ 36

10.5. Transformation von Bakterien___ 36

11. Gelelektrophorese von Nukleinsäuren______________________

11.1. Horizontalgelelektrophorese ___ 37

11.2. Vertikalgelelektrophorese __ 38

11.3. Elektrophorese von RNA im Agarosegel ___ 38

11.4. Längenstandards ___ 39

12. Isolierung von DNA-Fragmenten aus einem Agarosegel___ 39

12.1. Isolierung von DNA-Fragmenten mit der "Geneclean"-Methode____ 39

12.2. Isolierung von DNA-Fragmenten aus Polyacrylamidgelen___ 40

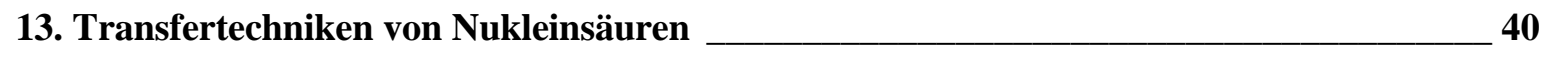

13.1. Transfer von DNA-Fragmenten: Southern-Blotting ___ 40

13.2. Transfer von RNA aus Agarosegelen (Northern-Blotting) ___ 41

14. Radioaktive Markierung von DNA ____________

14.1. "random priming" ___ 41

14.2. Endmarkierung von Oligonukleotiden ___ 42

14.3. Aufreinigung radioaktiver DNA-Sonden und sythetischer Oligonukleotide___ 43

15. Hybridisierung radioaktiver Sonden an membrangebundene DNA oder RNA ___ 43

16. Isolierung rekombinanter Klone aus einer Phagen-Bibliothek____ 44

16.1. Titerbestimmung der Phagen-Bibliothek____ 44

16.2. Ausplattieren der Phagen-Bibliothek __ 45

16.3. Transfer und Behandlung der Phagen auf Nitrocellulosefilter ___ 45

16.4. Anreicherung und Isolierung der positiven, rekombinanten Phagen___ 46

16.5. Anlegen eines Phgenstocks ___ 46

17. Methoden der "Polymerase Chain Reaction" (PCR) ___ 47

17.1. PCR an Plasmid-DNA___ 47 
17.2. PCR an genomischer DNA _ 48

17.3. "Reverse PCR" (RT-PCR)___ _ 49

18. MARATHON RACE-PCR ___ 50

18.1. Konstruktion von MARATHON cDNA-Banken __ 50

18.2. Synthese der MARATHON cDNA-Banken ___ 50

18.3. Screening der MARATHON cDNA-Banken ___ 52

19. Sequenzierungsanalyse ___ 53

19.1. Sequenzierungsreaktion _ـ 53

19.2. Sequenzierung-PCR __ 53

19.3. PAGE-Gel für die automatische Sequenzierung ___ 54

20. Primer Extension Analyse ___ 55

21. Verdauung der Poly (A) $)^{+}$- Schwanz von Gesamt-RNA____ 56

22. Herstellung von Paraffinschnitten aus Geweben, Organen und Embryonen ___ 56

23. ' whole mount' -in situ-Hybridisierung______________ 58

23.1. Präparation der Maus-Embryonen___ 58

23.2. Vorbehandlung der Embryonen___ 58

23.3. Synthese von RNA-Proben: DIG-Markierung ___ 59

23.4. Hybridisierung mit DIG-markierten RNA-Sonden ___ 60

23.5. Waschen nach der Hybridisierung___ 60

23.6. Detektion der Hybridisierungssignale ___ 61

24. Proteinchemische Techniken

24.1. Isolierung von Gesamtprotein aus Gewebe ___ 62

24.2. SDS-Polyacrylamidgel __ 62

24.3 'Semi dry blot' __ 63

24.4. Färbung von Polyacrylamidgelen ___ 64

24.5. Reversible Färbung von 'Western blots' ___ 64

24.6. Immunumsetzung von Proteinfiltern___ 65

24.7. Immunlokalisierung von Proteinen in Paraffinschnitten __ 65

25. Herstellung des polyklonalen Antikörpers gegen das HASH-Peptid ___ 66

25.1. Kopplung des synthetischen Peptids an BSA ___ 66

25.2. Gewinnung eines polyklonalen Antiserums ___ 66

25.3. Aufreinigung monospezifischer Antikörper ___ 67

26. Techniken zur Herstellung von 'Knock out' -Mäusen ___ 68

26.1. Routinekultur von ES-zellen ___ 68

26.2. Elektroporation und Selektion von ES-Zellen___ 69

26.3. Isolierung von ES-Zellklonen und deren Kryokonservierung ___ 69 
26.4. Isolierung von 2.5 Tage alten Mausembryonen 70

26.5. Aggregation von ES-Zellen___ 71

26.6. Embryo-Transfer in pseudoträchtige Mäuse ___ 72

26.7. Identifizierung von Chimären ___ 72

III. Ergebnisse _ 73

1. Isolierung der HASH-cDNA der Maus ___ 73

2. Charakterisierung und Vervollständigung der HASH-cDNA der Maus ___ 73

2.1. Expressionsanalyse des HASH-Gens der Maus __ 73

2.1.1. Expression des HASH-Gens in verschiedenen adulten Geweben ___ 73

2.1.2. Expression des HASH-Gens während der Testisentwicklung __ 75

2.1.3. Analyse der Expression des HASH-Gens in Testes von verschiedenen Mausmutanten mit Keimzelldefekten__ 76

2.1.4. Embryonale Expression des HASH-Gens der Maus ___ 77

2.1.4.1. Untersuchung der Expression des HASH-Gens während der Embryonalenentwicklung mittels RT-PCR 77

2.1.4.2. Identifizierung des Expressionsmusters des HASH-Gens während der Embryonalenentwicklung mittels 'whole mount'- in situ-Hybridisierung __ 79

2.2. Untersuchung zum alternativen Spleißen

2.2.1. Identifizierung der Länge der Poly(A)-Schwänze der drei HASH-Transkripte___ 81

2.2.2. 3'-alternatives Spleißen

2.2.3. Amplifikation der verschiedenen Exon-spezifischen cDNA-Fragmente mittels PCR bzw. RTPCR

2.2.4. Northern-Blot-Analysen mit den verschiedenen Exon-spezifischen cDNA-Fragmenten 85

2.3. Versuche zur Identifizierung des 5'-Endes der drei HASH-mRNAs mit Hilfe der Marathon-RACEPCR

2.3.1. Versuch zur Isolierung des 5'-Endes der HASHsoma 87

2.3.2. Versuch zur Isolierung des 5'-Endes der HASHgerm1.8_ 91

2.3.3. Versuch zur Isolierung des 5'-Endes der HASHgerm1.2 __ 93

2.4. cDNA Struktur der drei HASH-Transkripte ___ 95

2.5. Nukleotid- und Aminosäuresequenz der HASH-cDNA der Maus ___ 96

2.6. Identifizierung des Translationsproduktes der HASH-mRNAs___ 99

3. Isolierung und Charakterisierung der genomischen HASH-Klone der Maus ___ 102

3.1. Screenen der Phagen-Bibliothek mit dem cDNA-Fragment für Exon 3 und $4 \_102$

3.2. Versuche zur Isolierung der Promotorregionen des HASH-Gens der Maus ___ 106

3.2.1. Screenen der Cosmid-Bibliothek mit Exon $1 \ldots 106$

3.2.2. Screenen der Cosmid-Bibliothek mit dem cDNA-Fragment E8 ___ 108

3.3. Isolierung eines genomischen HASH Klons aus einer RZPD-Human-P1-Bibliothek ___ 110

3.4. Chromosomale Lokalisation des HASH-Gens des Menschen ___ 111 
4. Herstellung HASH-defizienter Mäuse 113

4.1. Die Strategie zur Deletion des HASH-Gens der Maus 113

4.2. Isolierung und Klonierung des 5'-flankierenden Fragments 115

4.3. Isolierung und Klonierung des 3'-flankierenden Fragments 116

4.4. Isolierung und Klonierung der externen 5'-Sonde 118

4.5. Analyse der selektierten ES-Zellen nach Elektroporation 118

4.6. Aggregation bzw. Blastocysteninjektion von ES-Zellen 121

4.7. Statistische Analyse der Nachkommen mittels PCR 123

4.8. Genotypisierung von Nachkommen durch Southern-Blot-Analyse 126

4.9. Erklärung des Ereignisses in Genom der Versuchsmäuse 128

4.9.1. Southern-Blot-Hybridisierung mit der internen Probe 128

4.9.2. Integration des Konstrukts innerhalb des 5'-flankierenden Bereichs 129

4.10. Weitere Versuche zur Herstellung der homozygoten $\mathrm{HASH}^{-/}$-Mäuse 130

IV. Diskussion 131

1. Analyse der HASH-cDNAs der Maus 131

2. Analyse der Primärstruktur des HASH-Proteins der Maus 135

3. Expressionsanalyse des HASH-Gens in der Maus 139

4. Charakterisierung putativer Promotoren im HASH-Gen 142

5. Chromosomale Lokalisation des HASH-Gens des Menschen 147

6. Alternatives Spleißen der HASH-mRNAs 147

7. Versuch zur Herstellung von $\mathrm{HASH}^{-/}$-Knock out-Mäusen 149

7.1. Insertion des Konstruktes innerhalb des 5'-flankierenden Bereiches 151

7.2. Phänotyp der $\mathrm{HASH}^{\text {neo/neo }}$-Insertionsmutante 154

V. Zusammenfassung 157

VI. Literatur 159

VII. Anhang 174

Sequenzen der verwendeten Oligonukleotide 174

Abkürzungen 175

Symbole für Aminosäuren 178 


\section{VERZEICHNIS DER ABBILDUNGEN}

Abb. 1: Gewebespezifische Expression des HASH-Gens der Maus

Abb. 2: Northern-Blot-Analyse der Expression des HASH-Gens der Maus in der postnatalen Testisentwicklung. 75

Abb. 3: Northern-Blot-Analyse zur Expression des HASH-Gens im Testis von verschiedenen Mutanten mit Keimzelldefekten.

Abb. 4: Expressionsanalyse des HASH-Gens der Maus während der Embryonalentwicklung mittels RT-

PCR.

Abb. 5: 'Whole mount' -in situ-Hybridisierung. .80

Abb. 6: Northern-Blot-Hybridisierung zur Identifizierung der Größe bzw. der Länge des Poly(A)Schwanzes der drei HASH-Transkripte der Maus.

Abb. 7: Schematische Darstellung der durch PCR amplifizierten, Exon-spezifischen Fragmente. ............84

Abb. 8: Northern-Blot-Analyse zur Erklärung des alternativen Spleißen..................................................85

Abb. 9: Schematische Darstellung der zur Amplifikation des 5' -Endes der HASHsoma verwendeten

Primer .88

Abb. 10: Amplifikation des 5'-Endes der HASHsoma mit Hilfe der Marathon-PCR. 89

Abb. 11: Neue cDNA Information von 5'-Upstream des Exons 1 und Northern-Blot-Analyse . .90

Abb. 12: Schematische Darstellung der zur Amplifikation des 5'-Endes der HASHgerm1.8 verwendeten Primern.

Abb. 13: Schematische Darstellung der zur Amplifikation des 5'-Endes der HASHgerm1.2 verwendeten Primern.

Abb. 14: Neue cDNA Information von 5'-Upstream des Exons 8 und Northern-Blot-Analyse..................94

Abb. 15: Schematische Darstellung der cDNA Struktur der drei HASH-Transkripte.............................95

Abb. 16: Nukleotidsequenz der HASH-cDNA und die daraus abgeleitete Aminosäuresequenz für das HASH-Protein der Maus.

Abb. 17: Western-Blot-Analyse mit dem polyklonalen HASH-Antiserum. 100

Abb. 18: Hybridisierungen der Restriktionsfragmente des genomischen Phagenklon hgmATG (A, B) und des Plasmidklons pZErO-hgmATG (C, D). 103

Abb. 19: Restrktionskarte und genomische Organisation des genomischen Klons pZErO-hgmATG und pZErO-K.

Abb. 20: Hybridisierung der Restriktionsfragmente der genomischen Cosmidklone Hcos-A und -B..... 107

Abb. 21: Southern-Blot-Analyse des genomischen Cosmidklons Hcos-D.

Abb. 22: Hybridisierung des humanen genomischen P1-Klons hH1. 110

Abb. 23: Chromosomale Lokalisation des HASH-Gens des Menschen.

Abb. 24: Strategie zur Deletion des HASH-Gens der Maus.

Abb. 25: Restriktionsenzymatischer Nachweis der Orientierung des 5'-flankierenden Fragments im pPNT-Vektor.

Abb. 26: Restriktionsenzymatischer Nachweis der Umklonierung des $3^{\prime}$-flankierenden Fragments im 
pPNT-H-5 117

Abb. 27: Southern-Blot-Analyse mit DNA positiver ES-Zellklone nach Elektroporation mit dem Targeting-Vektor pPNT- $\Delta$ HASH. . 120

Abb. 28: Genotypisierung der Nachkommen der Chimäre \#18 durch PCR (Hintergrund NMRI). 122

Abb. 29: Genotypisierung der 10.5 Tage alten Embryonen eines Wurfes der F2-Generation durch Southern-Blot-Analyse.

Abb. 30: Southern-Blot-Analyse zur Genotypisierung der F2-Generation (Hintergrund NMRI)........... 126

Abb. 31: Southern-Blot-Hybridisierung mit der internen Probe HIP.

Abb. 32: Vergleich der aus den cDNA-Sequenzen des HASH-Gens von Maus, Ratte und des Menschen abgeleiteten Aminosäuresequenzen.

Abb. 33: Schematische Darstellung der Lokalisierung der putativen Promoterregionen der drei HASHTranskripte.

Abb. 34: Putative cis-ständige Elemente für den Transkriptionsfaktor Nkx2.5 (A) und GATA (B) in der Promotorregion für das 2.6 Kb HASH-Transkript.

Abb. 35: Putative cis-ständige Elemente für den Transkriptionsfaktor AP-1 in der Promotorregion für das 1.2 Kb HASH-Transkript. 146

Abb. 36: Schematische Darstellung der Insertion des Konstruktes. 152

Abb. 37: Schematische Darstellung von Integrationsmöglichkeit des Targeting-Vektors. 153

Abb. 38: Abnormalität des Kopfes der 10.5 (A)- und 12.5 (B)-Tage alten HASH ${ }^{\text {neo/neo }}$-Embryonen. 155

\section{VERZEICHNIS DER TABELLEN}

Tab. 1: Zusammenfassung der Ergebnisse aus den Aggregationen bzw. aus den Blastocysteninjektionen.

Tab. 2: Quantitative Verteilung von Wildtyp- und heterozygoten Mäusen in der F1-Generation 123

Tab. 3: Vergleich der Verteilung von Wildtyp- heterozygoten und homozygoten Mäusen in der F1- und F2-Generation auf NMRI-Hintergrund.

Tab. 4: Quantitative Verteilung von Wildtyp-, heterozygoten und homozygoten Mäusen in der F2Generation (Hintergrund NMRI)

Tab. 5: Zusammenstellung der homologen EST-Klone der HASH-cDNA (Maus, Ratte und Mensch); es wurden die Originaleinträge in den EST-Datenbanken übernommen.

Tab. 6: Aminosäurezusammensetzung des HASH-Proteins der Maus.................................................. 136

Tab. 7: Zusammenstellung der putativen Phosphorylierungsstellen des HASH-Proteins.

Tab. 8: Quantitative Verteilung von Wildtyp-, heterozygoten und homozygoten Mäusen in der F2Generation auf dem Hintergrund 129/SvJ (A) und auf dem Hintergrund NMRI (B) 


\section{EINLEITUNG}

\section{Spermatogenese und Genexpression}

Als Spermatogenese bezeichnet man den hochkomplexen Differenzierungsvorgang, in dessen Verlauf, ausgehend von der diploiden Spermatogonie, durch morphologische und funktionelle Veränderungen der Keimzellen reife Spermatozoen entstehen. Diese sind aufgrund ihrer Motilität und genetischen Ausstattung in der Lage, Oozyten $\mathrm{zu}$ befruchten und neue Individuen entstehen $\mathrm{zu}$ lassen. Die Samenzellbildung findet innerhalb der Tubuli seminiferi des Testis statt. Hier bauen die Keimzellen zusammen mit den Sertolizellen, die das somatische Grundgerüst bilden, das Keimepithel auf (Fawcett, 1979). Außerhalb dieser tubulären Strukturen besteht der Testis aus lockerem, interstitiellem Bindegewebe, Blut- und Lymphgefäßen, Nervenfasern, intertubulär gelegenen, Testosteron-produzierenden LeydigZellen und peritubulären Myoid-Zellen, welche die Wanderung der reifen Spermatozoen durch das Epithellumen ermöglichen. Im Gegensatz zum Menschen, bei dem der Ablauf der Spermatogenese 64 Tage andauert (Chubb, 1993), erfolgt der Spermatogeneseprozeß bei der Maus, auf die sich im folgenden alle Ausführungen beziehen, innerhalb von etwa 34 Tagen. Bei Säugern läßt sich die Spermatogenese prinzipiell in drei Phasen gliedern: 1) Die Proliferationsphase, in der sich die Spermatogonien durch mehrere mitotische Teilungen vermehren und anschließend zu primären Spermatozyten differenzieren; 2) Die meiotische Phase, in der das genetische Material der Spermatozyten durch 'crossing over' rekombiniert und halbiert wird; 3) Die postmeiotische Phase (Spermiogenese), in der die haploiden Spermatiden zu befruchtungsfähigen Spermatozoen komplettiert werden (Russel, 1990).

Für den koordinierten Ablauf der Spermatogenese und die Ausbildung der hochspezialisierten Struktur und Funktion der Spermien ist die Expression zahlreicher Spermatogenese-spezifisch exprimierter Gene (etwa 2000) notwendig. Diese Gene können in zwei große Gruppen unterteilt werden: 1. Gene, die diploid exprimiert werden und 2. Gene, die haploid exprimiert werden. Als Beispiele seien das Proakrosingen für diploide Expression (Adham et al., 1989; Kremling et al., 1991; Kashiwabara et.al., 1990) und das Transitionsprotein 2 Gen für die haploide Expression (Luerssen et al., 1989; Kremling et al., 
1989; Kim et al., 1992; Schlüter et al., 1992) genannt. Andere Gene kodieren für keimzellspezifische Isoformen, deren Proteine auch in somatischen Zellen vorhanden sind. Beispiele für diese Gruppe sind die Gene für die Phosphoglyceratkinase-2 (Boer et al., 1987) und für das testisspezifische Isoenzym des 'angiotensin converting enzyme' (Ehlers et al., 1989). Gene, die sowohl in den Keimzellen als auch in somatischen Organen exprimiert werden, produzieren häufig keimzellspezifische Transkripte. Sie können auf alternatives 'splicing' der RNA, auf die Nutzung verschiedener Promotoren oder auf alternative Polyadenylierungssignale zurückgeführt werden (Oppi et al., 1987; Howard et al., 1990). Die Expression dieser Gene bleibt während der Spermatogenese häufig auf bestimmte Keimzellstadien beschränkt (Stern et al., 1983; Wilson et al., 1987) und wird sowohl auf der Ebene der Transkription als auch der Translation kontrolliert (Hecht, 1990; Kleene, 1993; Schäfer et al., 1995).

Die Regulation eines testisspezifisch exprimierten Gens erfordert einen komplexen Kontrollmechanismus. Dabei müssen Faktoren die gewebespezifische als auch entwicklungsspezifische Transkription des Gens gewährleisten. An diesen Prozeß sind sowohl spezifische als auch ubiquitär vorkommende Proteine ('trans-acting factors' oder Transkriptionsfaktoren) beteiligt, die an die Promotorsequenzen des Gens ('cis-acting elements') binden und so die Transkription regulieren (Jones et al., 1988; Mitchell und Tijan, 1989). Gene, die zu einem bestimmten Zeitpunkt in der Entwicklung oder in einem Gewebe gemeinsam exprimiert werden, haben in der Regel in der Promotorregion 'upstream' des Transkriptionsstartpunktes analoge Sequenzen (Maniatis et al., 1987; Jones et al., 1988; Johnson et al., 1991). Diese cis-ständigen Elemente sollten einen essentiellen Einfluß auf das spezifische Expressionsmuster der Gene haben. Der Nachweis der Funktion dieser Sequenzen konnte mittels künstlicher Mutationen in der Protein-Bindungssequenz und dem daraus resultierenden Verlust der Bindungsspezifität erbracht werden (Wirth et al., 1987; Beato, 1989). Bislang wurde eine Vielzahl kurzer DNA-Sequenzen identifiziert, die für die basale Genexpression verantwortlich sind. Die cis-regulatorischen Elemente können mehrere transagierende Faktoren binden und somit die Spezifität der Genexpression wesentlich komplexer gestalten, als dies bei der Interaktion einer DNA-Sequenz mit einem einzigen Protein der Fall ist (Locker und Buzard, 1990). Die Erhöhung der Transkriptionseffizienz wird durch die Interaktion mit weiteren trans-agierenden Faktoren bewirkt (Ptashne und Gann, 1990). Bei den Transkriptionsfaktoren handelt es sich um Proteine, die miteinander und zusätzlich mit der RNA-Polymerase II interagieren können und die Expression von Genen steuern. 


\section{Das HASH-Gen}

Die cDNA für das Gen HASH ( $\underline{H}$ anne $\underline{A}$ ho und Rahman $\underline{S h a m s a d i n)}$ wurde im Rahmen eines Versuches gefunden, bei dem ein Transkriptionsfaktor für das Proakrosingen isoliert werden sollte. Zwar wurde die cDNA durch das Screenen einer Testis- $\lambda$ gt11-Expressionsbibliothek der Ratte mit einem Promotorfragment (F4) des Proakrosingens, an das im 'gel retardation assay' ein Protein aus Testisextrakten bindet, von Keime (1993) isoliert und weiterhin von Shamsadin (1995) und Aho (1997) charakterisiert. Aber in weiteren 'gel retardation assays' zur Bestätigung konnten keine spezifische Interaktionen zwischen dem Fragment F4 und den Fusionsproteinen aus HASH-cDNA nachgewiesen werden. Die nachfolgenden Expressionsanalysen mit HASH-cDNA zeigten jedoch eine testisspezifische Expression des HASH-Gens bei Ratte und Maus. Durch Northern-BlotExperimente konnte nachgewiesen werden, daß das HASH-Gen in Testis von Ratte und Maus exprimiert ist, und zwar mit drei Transkripten mit eine Länge von $2.9 \mathrm{~Kb}, 2.3 \mathrm{~Kb}$ und $1.5 \mathrm{~Kb}$. Zusätzlich konnte eine schwache Expression des $2.9 \mathrm{~Kb}$ Transkriptes in Ovar und Thymus der beiden Spezies und in Placenta der Maus nachgewiesen werden. Auf zellulärer Ebene konnte auch eine Expression für das 2.9 Kb Transkript in diploiden Keimzellen, ES-Zellen, Leydig- und Sertolizellen gezeigt werden. Die $2.3 \mathrm{~Kb}$ und $1.5 \mathrm{~Kb}$ Transkripte wurden dagegen nur in haploiden Keimzellen gefunden. In weiteren Northern-Blot-Analysen wurde bestätigt, daß die drei Transkripte des HASH-Gens durch alternatives Spleißen entstanden sind. Das HASH-Gen der Ratte wurde mit Hilfe mehrerer HASH-cDNA-Fragmente aus drei verschiedenen genomischen Bänken isoliert. Es konnten 12 Exons und 11 Introns charakterisiert werden. Das HASH-Gen hat eine Größe von über $100 \mathrm{~Kb}$, und es liegt im Rattengenom als 'single copy'-Gen vor. Es wurde auf Chromosom 5 der Ratte, in der Region q34-q35, lokalisiert. 


\section{Ziele der vorliegenden Arbeit}

Die Aufgabe der vorliegenden Arbeit war eine möglichst detaillierte Charakterisierung des HASH-Gens der Maus.

Zunächst sollten die Sequenzen der HASH-cDNAs bei der Maus vervollständigt, die zugehörigen genomischen Klone isoliert und die genomische Organisation bestimmt werden. Weiterhin sollte die chromosomale Lokalisation des HASH-Gens bei Maus und Mensch identifiziert werden, um so weitere Informationen über das HASH Gen zu erhalten.

Ein weiterer Aspekt war die Analyse der spezifischen Expression in verschiedenen Organen und die Erstellung eines prä- bzw. postnatalen Expressionsprofils mit Hilfe von NorthernBlot-Hybridisierungen, RT-PCR und in situ-Hybridisierungen.

Das Hauptziel dieser Arbeit sollte aber sein, die Funktion des HASH-Gens bei der Maus zu studieren. $\mathrm{Zu}$ diesem Zweck sollte das Gen durch die Methode der homologen Rekombination in embryonalen Stammzellen inaktiviert werden. Über deren Aggregation oder Blastocysteninjektion sollten Chimären erzeugt und durch geeignete Verpaarungen Mäuse produziert werden, die das homolog rekombinierte Allel im heterozygoten $(+/-)$ und homozygoten $(-l)$ Zustand enthalten. Weiterhin sollten die mit dieser Nullmutation einhergehenden funktionellen Veränderungen der Maus untersucht werden. 


\section{MATERIAL UND METHODEN}

\section{Chemikalien}

Alle Chemikalien, die nicht gesondert aufgeführt sind, wurden von der Firma Merck, Darmstadt in p.A. Qualität bezogen.

Acrylamid

Agar

Agarose

Ammoniumacetat

Ampicillin

Ampuwa

Bacto-Tryptone

Bacto-Yeast-Extrakt

Bindesilan

Bisacrylamid

Blockierungspluver

Bromphenolblau

BSA

Chloroform

Dextransulfat

Diethylpyrocarbonat (DEPC)

Dimethylsulfoxid (DMSO)

Dithiothreitol

DNase I (RNase-frei)

dNTPs (100 mM)

Ethanol

Ethidiumbromid

Ficoll 400

FKS

Formaldehyd

Formamid

Geneclean-Kit

Glycerol
Serva, Heidelberg

Difco, Detroit, USA

Gibco/BRL, Eggenstein

Fluka, Neu Ulm

Sigma, Deisenhofen

Fresenius AG, Bad Homburg

Difco, Detroit, USA

Difco, Detroit, USA

Fluka, Neu Ulm

Serva, Heidelberg

Boehringer, Mannheim

Sigma, Deisenhofen

Biomol, Hamburg

Baker, Deventer, NL

Pharmacia, Freiburg

Sigma, Deisenhofen

Merck, Darmstadt

Sigma, Deisenhofen

Pharmacia, Freiburg

Boehringer, Mannheim

Baker, Deventer, NL

Sigma, Deisenhofen

Pharmacia, Freiburg

Gibco/BRL, Eggenstein

Gibco/BRL, Eggenstein

Fluka, Neu Ulm

Dianova, Hamburg

Gibco/BRL, Eggenstein 
Guanidiniumthiocyanat

Harnstoff

Heparin

IPTG

Jetsorb Gel Extraction Kit/300

Kanamycin

Klenow-DNA-Polymerase

$\mathrm{Kb}$ Ladder

Lachsspermien-DNA

Lambda-DNA

Levamisole

LMP-Agarose

Lysozym

Magnesiumsulfat

Methylbenzoat

$\beta$-Mercaptoethanol

Mineralöl

Multipriming Kit

Oligo (dT) Cellulose

Orange-G

PBS

Parablast

Pikrinsäure

Phenol

Plasmid-Midipräp Kit

Phagen-Maxipräp Kit

Polyethylenglycol 6000

Proteinase K

Radioaktiv markierte Reagenzien: [ $\left.\alpha^{32} \mathrm{P}\right]-$ Amersham, Braunschweig dCTP, [ $\left.\Upsilon^{32} \mathrm{P}\right]-\mathrm{dATP}$

'Ready to go' (DNA Labelling Kit)

Restriktionsenzyme

Reverse Transkriptase

RNase A

RNase $\mathrm{H}$

RNase Inhibitor

RNA-Längenstandard

RNA Now-Kit

Fluka, Neu Ulm
ICN Biomedicals Inc., Cleveland, USA

Sigma, Deisenhofen

Biomol, Hamburg

Genomed, Bad Oeynhausen

Sigma, Deisenhofen

Amersham, Braunschweig

Gibco/BRL, Eggenstein

Sigma, Deisenhofen

Boehringer, Mannheim

Fulka, Neu Ulm

Gibco/BRL, Eggenstein

Sigma, Deisenhofen

Pharmacia, Freiburg

Fulka, Neu Ulm

Serva, Heidelberg

Sigma, Deisenhofen

Amersham, Braunschweig

Sigma, Deisenhofen

Sigma, Deisenhofen

Gibco/BRL, Eggenstein

Sigma, Deisenhofen

Fulka, Neu Ulm

Gibco/BRL, Eggenstein

Qiagen, Hilden

Qiagen, Hilden

Serva, Heidelberg

Boehringer, Mannheim

Pharmacia, Freiburg

Biolabs, Boehringer, BRL

Gibco/BRL, Eggenstein

Gibco/BRL, Eggenstein

Gibco/BRL, Eggenstein

Boehringer, Mannheim

Gibco/BRL, Eggenstein

ITC Biotchnology, Heidelberg 
SDS

Select Peptone

SP6 RNA-Polymerase

$\mathrm{T}_{4}$-DNA-Ligase

$\mathrm{T}_{4}$-DNA-Polymerase

$\mathrm{T}_{4}$-Polynukleotid-Kinase

T7 RNA-polymerase

Taq-DNA-Polymerase

TEMED

Tris

t-RNA (Bäckerhefe)

Tween-20

$\mathrm{X}-\mathrm{Gal}$

Xylencyanol

Zellkulturmedien
Serva, Heidelberg

Gibco/BRL, Eggenstein

Boehringer, Mannheim

Boehringer, Mannheim

Boehringer, Mannheim

Gibco/BRL, Eggenstein

Boehringer, Mannheim

Amersham, Braunschweig

Serva, Heidelberg

Sigma, Deisenhofen

Boehringer, Mannheim

Sigma, Deisenhofen

Biomol, Hamburg

Bio-Rad, München

Gibco/BRL, Eggenstein; Sigma, Deisenhofen

\section{Gebrauchswaren}

Gebrauchswaren, die nicht gesondert aufgeführt sind, wurden von den Firmen Schütt bzw. Krannich, Göttingen, bezogen.

Blottingpapier GB-003

DEAE-Membran NA45

Dialyseschläuche

Einmalfilter Minisart

NML (Porengrße 0.20

Filterpapier 0858

Hybond C Membran

Hybond N Membran

Membranfilter

$\mathrm{NAP}^{\mathrm{TM}} 5$ Sepahdex G25-Säulen

Nitrocellulosefilter BA 85

Petrischalen

Pipettenspitzen

Polyallomer-Ultrazentrifugenröhrchen
Schleicher \& Schüll, Dassel

Schleicher \& Schüll, Dassel

Serva, Heidelberg

Sartorius, Göttingen

Schleicher \& Schüll, Dassel

Amersham, Braunschweig

Amersham, Braunschweig

Millipore, Morlsheim

Pharmacia, Freiburg

Schleicher \& Schüll, Dassel

Greiner Nunc., Nürtingen

Eppendorf, Hamburg

Beckmann, München 
Reaktionsgefäße

Röntgenfilme (Hyperfilm ${ }^{\mathrm{TM}}-\mathrm{MP}$ )

Ultrazentrifugenröhrchen

Zentrifugengefäße u. -röhrchen

Zellkulturflaschen
Eppendorf, Hamburg

Amersham, Braunschweig

Beckmann, München

Beckmann, München

Greiner Nunc., Nürtingen

\section{Sterilisation}

Die Sterilisation von Lösungen erfolgte für $60 \mathrm{~min}$ bei $120^{\circ} \mathrm{C}$ und $10^{5}$ Pascal im Dampfdruckautoklaven (Webeco, Bad Schwartau) oder bei hitzeempfindlichen Lösungen durch Sterilfiltration (Porengröße: $0.2 \mu \mathrm{m}$ ). Gebrauchswaren wurden entweder autoklaviert oder über Nacht bei $220^{\circ} \mathrm{C}$ hitzesterilisiert.

\section{Puffer und Stammlösungen}

Lösungen für den routinemäßigen Gebrauch wurden nach Sambrook et al. (1989) angesetzt. Die benötigten Chemikalien wurden den Erfordernissen gemäß in bidestilliertem oder DEPC behandeltem Wasser gelöst und nach Bedarf autoklaviert oder steril filtriert (siehe II.3.).

Acrylamid-Stammlösung (40\%)

BBL-Agar

BCIP-Stammlösung
38 g Acrylamid

2 g Bisacrylamid

auf $100 \mathrm{ml} \mathrm{H}_{2} \mathrm{O}$

$10 \mathrm{~g}$ BBL Trypticase

$5 \mathrm{~g} \mathrm{NaCl}$

$6.5 \mathrm{~g}$ Agar

auf $1000 \mathrm{ml} \mathrm{H}_{2} \mathrm{O}$

$50 \mathrm{mg} / \mathrm{ml}$ in Dimethylformamid 
Bindesilan-Lösung

Denaturierungslösung

Denhardt's-Lösung (50x)

dNTP-Mix

Depurinierungslösung

E-Puffer (10x)

Elutionspuffer

Färbelösung

Fixiergemisch

GET-Puffer
$10 \mathrm{ml}$ abs. Ethanol

$30 \mu \mathrm{l}$ Bindesilan

$330 \mu 1$ 10\% Essigsäure

$1.5 \mathrm{M} \mathrm{NaCl}$

$0.5 \mathrm{M} \mathrm{NaOH}$

$1 \%$ BSA

$1 \%$ Polyvinylpyrrolidon

$1 \%$ Ficoll 400

in 20x SSC (pH 7.0)

$2 \mathrm{mM}$ dATP

$2 \mathrm{mM}$ dGTP

$2 \mathrm{mM}$ dCTP

$2 \mathrm{mM}$ dTTP

$0.25 \mathrm{M} \mathrm{HCl}$

$300 \mathrm{mM} \mathrm{NaH}_{2} \mathrm{PO}_{4}$

$50 \mathrm{mM}$ EDTA

$1.5 \mathrm{M} \mathrm{NaCl}$

$20 \mathrm{mM}$ Tris- $\mathrm{HCl}(\mathrm{pH} 7.5)$

$1 \mathrm{mM}$ EDTA

$4.5 \mu \mathrm{l} \mathrm{NBT}(75 \mathrm{mg} / \mathrm{ml}$ in $70 \% \mathrm{DMF})$

$3.5 \mu 1$ BCIP (50 mg/ml in 70\% DMF)

ad $10 \mathrm{ml}$ Puffer 3

15 Vol. Pikrinsäure (gesätigt in $\mathrm{dH}_{2} \mathrm{O}$ )

5 Vol. Formaldehyd

1 Vol. Essigsäure

$50 \mathrm{mM}$ Glucose

$10 \mathrm{mM}$ EDTA

$25 \mathrm{mM}$ Tris- $\mathrm{HCl}(\mathrm{pH} 8.0)$ 
Hybridisierungslösung I

Hybridisierungslösung II

Hybridisierungspuffer (5x)

Kinasepuffer (10x)

Lachs-Spermien-DNA

LB-Agar

LB-Medium

Ligationspuffer (10x)

Lösung D 5x SSPE-Lösung

5x Denhardt's-Lösung

$0.1 \%$ SDS

5x SSC

5x Denhardt's-Lösung

$10 \%$ Dextransulfat

$0.1 \%$ SDS

$1.5 \mathrm{M} \mathrm{NaCl}$

$50 \mathrm{mM}$ Tris- $\mathrm{HCl}(\mathrm{pH} 7.5)$

5 mM EDTA

100 mM Tris- $\mathrm{HCl}$ (pH 7.4)

$100 \mathrm{mM} \mathrm{MgCl}{ }_{2}$

$100 \mathrm{mM}$ DTT

$1 \mathrm{mM}$ ATP

$100 \mu \mathrm{g} / \mathrm{ml}$

10 g Bacto-Trypton

5 g Hefeextrakt

$10 \mathrm{~g} \mathrm{NaCl}$

$15 \mathrm{~g} \mathrm{Agar}$

auf $1000 \mathrm{ml} \mathrm{H}_{2} \mathrm{O}$

10 g Bacto-Trypton

$5 \mathrm{~g}$ Hefeextrakt

$10 \mathrm{~g} \mathrm{NaCl}$

auf $1000 \mathrm{ml} \mathrm{H}_{2} \mathrm{O}$

600 mM Tris- $\mathrm{HCl}$ (pH 7.5)

$80 \mathrm{mM} \mathrm{MgCl}{ }_{2}$ 100 mM DTT

4.0 M Guanidiniumthiocyanat

$25.0 \mathrm{mM}$ Natriumcitrat ( $\mathrm{pH}$ 7.0)

$0.5 \%$ Sarcosyl 
0.1 M $\beta$-2-Mercaptoethanol

Lysis-Puffer I

$100 \mathrm{mM} \mathrm{NaCl}$

100 mM Tris- $\mathrm{HCl}$ (pH 8.0)

$100 \mathrm{mM}$ EDTA

$0.2 \mathrm{mg} / \mathrm{ml}$ Proteinase $\mathrm{K}$

$0.5 \%$ SDS

Lysis-Puffer II

$0.35 \mathrm{M} \mathrm{NaCl}$

$10 \mathrm{mM}$ Tris- $\mathrm{HCl}$ (pH 8.0)

$1 \mathrm{mM}$ EDTA

Methylenblau-Lösung

$0.5 \mathrm{M} \mathrm{NaAc}(\mathrm{pH} 5.2)$

$0.04 \%$ Methylenblau

$\mathrm{NaOH} / \mathrm{SDS}$-Lösung

$1 \%$ SDS

$0.2 \mathrm{M} \mathrm{NaOH}$

NBT

$75 \mathrm{mg} / \mathrm{ml}$ in $70 \%$ Dimethylformamid

Neutralisierungslösung

$1.5 \mathrm{M} \mathrm{NaCl}$

$1 \mathrm{M}$ Tris- $\mathrm{HCl}(\mathrm{pH} 7.0)$

Phagenpuffer

$10 \mathrm{mM} \mathrm{MgCl}{ }_{2}$

10 mM Tris- $\mathrm{HCl}$ (pH 7.5)

$20 \mathrm{mM} \mathrm{NaCl}$

PBS-Puffer

$130 \mathrm{mM} \mathrm{NaCl}$

$7 \mathrm{mM} \mathrm{Na}_{2} \mathrm{HPO}_{4}$

$4 \mathrm{mM} \mathrm{NaH}_{2} \mathrm{HPO}_{4}$

PBT-Puffer

$0.1 \%$ Tween-20 in PBS (1x)

RNase A

$10 \mathrm{mg} / \mathrm{ml}$ in $\mathrm{dH}_{2} \mathrm{O}$

15 min bei $100^{\circ} \mathrm{C}$ im Wasserbad

$\operatorname{SSC}(20 x)$

$3 \mathrm{M} \mathrm{NaCl}$

0.3 M Tri-Natriumcitrat 
$(\mathrm{pH} 7.0$ mit $\mathrm{NaOH})$

$\operatorname{SSPE}(20 \mathrm{x})$

0.02 M EDTA

$0.2 \mathrm{M} \mathrm{NaH}_{2} \mathrm{PO}_{4} \cdot \mathrm{H}_{2} \mathrm{O}$

$3.6 \mathrm{M} \mathrm{NaCl}$

(pH 7.0 mit $\mathrm{NaOH})$

Stop-Mix I

95\% Formamid

$20 \mathrm{mM}$ EDTA

0.05\% Bromphenolblau

$0.05 \%$ Xylencyanol

Stop-Mix II

15\% Ficoll 400

$200 \mathrm{mM}$ EDTA

$0.1 \%$ Orange $\mathrm{G}$

TAE-Puffer

$200 \mathrm{mM}$ Tris

$200 \mathrm{mM}$ Essigsäure

5 mM EDTA (pH 8.0)

TBE-Puffer (5x)

445 mM Tris- $\mathrm{HCl}$ (pH 8.0)

445 mM Borsäure

$10 \mathrm{mM}$ EDTA

TE-Puffer

10 mM Tris- $\mathrm{HCl}$ (pH 8.0)

$1 \mathrm{mM}$ EDTA

TNE-Puffer

$10 \mathrm{mM}$ Tris/HCl (pH 8.0)

$100 \mathrm{mM} \mathrm{NaCl}$

$1 \mathrm{mM}$ EDTA

Toluidinblau-Lösung

$70 \%$ Ethanol

$1 \%$ Toluidinblau

TPE (10x)

0.8 M Tris-Phosphat ( $\mathrm{pH} 8.0$ )

0.02 M EDTA

Waschlösung I

2x SSC 


\section{$0.1 \%$ SDS}

Waschlösung II

$0.2 \mathrm{xSSC}$

\section{Medien, Agarplatten und Antibiotika}

\subsection{Medien für Bakterien und Phagen}

\begin{tabular}{|c|c|c|}
\hline LB-Medium (pH 7.5): & $1 \%$ & Trypton \\
\hline & $0.5 \%$ & Hefeextrakt \\
\hline & $0.5 \%$ & $\mathrm{NaCl}$ \\
\hline & $1.5 \%$ & Agar \\
\hline
\end{tabular}

Das LB-Medium wurde mit bidestilliertem Wasser angesetzt, autoklaviert und bei $4^{\circ} \mathrm{C}$ aufbewahrt.

\subsection{Antibiotika}

Von den Antibiotika Ampicillin und Kanamycin wurden Stammlösungen angesetzt, die steril filtriert und bei $-20^{\circ} \mathrm{C}$ gelagert wurden. Das jeweils benötigte Antibiotikum wurde erst nach dem Autoklavieren und Abkühlen der Wachstumsmedien auf $55^{\circ} \mathrm{C}$ zugegeben.

$\begin{array}{llll} & \text { Stammlösung } & \text { gelöst in } & \text { Endkonzentration } \\ \text { Ampicillin } & 50 \mathrm{mg} / \mathrm{ml} & \mathrm{H}_{2} \mathrm{O} & 50 \mu \mathrm{g} / \mathrm{ml} \\ \text { Kanamycin } & 25 \mathrm{mg} / \mathrm{ml} & \mathrm{H}_{2} \mathrm{O} & 50 \mu \mathrm{g} / \mathrm{ml}\end{array}$




\subsection{X-Gal-Platten}

Zur Herstellung von X-Gal-Platten (Blau-Weiß-Selektion) wurden dem LB-Agar $\left(55^{\circ} \mathrm{C}\right)$ Ampicillin, IPTG und X-Gal in entsprechenden Konzentrationen zugegeben und in Petrischalen gegossen. Die Platten wurden bei $4^{\circ} \mathrm{C}$ gelagert.

$\begin{array}{llll} & \text { Stammlösung } & \text { gelöst in } & \text { Endkonzentration } \\ \text { X-Gal } & 2 \% & \text { N.N.-Dimethylformamid } & 0.0004 \% \\ \text { IPTG } & 100 \mathrm{mM} & \mathrm{H}_{2} \mathrm{O} & 1 \mathrm{mM}\end{array}$

\subsection{Medien für Zellkultur}

Die zur Kultur von eukaryotischen Zellen verwendeten Medien wurden gekauft (Biochrom, Berlin; Sigma, Deisenhofen) und vor Gebrauch je nach Kulturbedingung der Zellen mit fötalem Kälberserum (FKS) bzw. Pferdeserum (HS), Antibiotika (Penicillin/ Streptomycin/ Gentamycin) und Glutamin versetzt und sterilfiltriert. Für die Zellkultur wurden folgende Medien verwendet:

ES-Zellmedium:

DULBECCO’s MEM (DMEM)

$0.1 \mathrm{mM}$ nicht essentielle Aminosäuren

$1 \mathrm{mM}$ Natrium-Pyruvat

10-6 M B-Mercaptoethanol

2 mM L-Glutamin

$20 \%$ FKS

$1000 \mathrm{U} / \mathrm{ml} \mathrm{LIF}$

Fibroblasten-Zellmedium:

DULBECCO’s MEM (DMEM)

2 mM L-Glutamin

$10 \%$ FKS 
Zur Langzeitlagerung der Zellen in flüssigem Stickstoff wurden folgenden Einfriermedien verwendet:

$\begin{array}{ll}\text { RI-ES-Zellen } & 30 \% \text { ES-Zellmedium, 50\% FKS, 20\% DMSO } \\ \text { EmFi-Zellen } & 30 \% \text { EmFi-Zellmedium, 50\% FKS, 20\% DMSO }\end{array}$

\section{Verwendete Bakterienstämme, Vektoren, Gensonden, Bibliotheken und Zellinien}

\subsection{Bakterienstämme}

Zur Vermehrung der Vektoren bzw. der rekombinanten DNA wurden folgende Wirtsstämme eingesetzt:
E. coli Y 1008
Young and Davis, 1983
E. coli LE 392
Murray et al., 1977
E. coli $\mathrm{HB} 101$
Bolivar und Beckmann, 1979
E. coli JM 109
Promega, Wisconsin, USA
E. coli $\mathrm{DH} 5 \alpha$
Hanahan et al., 1985
E. coli TOP10'
Invitrogen, Leek, Niederlande

\subsection{Plasmide, Phagemide und Lamda-Vektor}

EMBL3

Lambda gt1 1

Lambda Fix II

Lawrist 7

pBluesript SK (+/-)

pGEM 3zf+
Frischauf et al., 1983

Young and Davis, 1983

Clontech, Palo Alto, USA

RZPD, Berlin

Stratagene, La Jolla, USA

Promega, Wisconsin, USA 


$\begin{array}{ll}\text { pGEM-T } & \text { Promega, Wisconsin, USA } \\ \text { pPNT } & \text { Tybulewicz et al., 1991 } \\ \text { pUC } 18 & \text { Norander et al., 1983 } \\ \text { pZErO-2 } & \text { Invitrogen, Leek, Niederlande }\end{array}$

\subsection{Synthetische Oligonukleotide}

Alle Oligonukleotide, die für Experimente verwendet wurden, wurden von den Firmen NAPS (Göttingen) und ROTH (Karlsruhe) in der Konzentration von 100 pmol/ml hergestellt.

\subsection{Gensonde}

Bei Northern-Blot-Rehybridisierung wurde die Integrität der eingesetzten RNA mit der 1.6 kb langen cDNA für den humanen Elongationsfaktor 2 (hEF) überprüft (Rapp et al., 1989).

\subsection{Bibliotheken}

Maus Testis cDNA Bibliothek (Clontech):
Vektor:
Lambda gt 11
Wirtsstamm:
E. coli Y 1090r

Maus genomische Bibliothek (RZPD):
Vektor:
Lawrist 7
Wirtsstamm:
E. coli $\mathrm{DH} 5 \alpha$ 


\subsection{Eukaryotische Zell-Linien}

EmFi Embryonale Fibroblasten

Dr. Adham, Humangenetik, Göttingen

Adham et al., 1997

RI Embryonale Stammzellen der Passage 11

Dr. A. Nagi, Toronto, Kanada

\section{Mausstämme}

Für die Gewinnung von 2.5 Tage alten Mausembryonen wurden Weibchen des Stammes CD1 nach natürlicher Verpaarung verwendet. Als Ammen-Mütter dienten pseudoträchtige Weibchen des Stammes NMRI. Sterile Männchen für die Bereitstellung von pseudoträchtigen Weibchen wurden durch Vasektomierung von Männchen des Stammes NMRI nach den Angaben von Hogan et al. (1994) generiert. Alle Mäuse wurden entweder über die Firma Charles River (Hannover) bezogen oder stammten aus institutseigenen Beständen. Für die Rückkreuzung der Chimären wurden Mäuse der Stämme CD-1 oder 129/SvJ benutzt. 


\section{Standardmethoden und -reaktionen in der Molekularbiologie}

Alle gentechnologischen Arbeitsschritte wurden nach den eingeführten molekularbiologischen Standardmethoden durchgeführt, wie sie z.B. in Sambrook et al. (1989) bzw. Ausubel et al. (1992) niedergelegt sind. Reagenzien und Proben für die Durchführung enzymatischer Reaktionen wurden grundsätzlich auf Eis gekühlt und wurden, sofern nicht anders angegeben, mit den mitgelieferten Puffersystemen der Hersteller angesetzt.

Wenn nicht anders angegeben, wurden folgende Standartmethoden nach „Molecular Cloning“ (Sambrook et al., 1989) und „Current Protocols in Molecular Biology“ (Ausubel et al., 1992) durchgeführt:

- Spaltung von DNA mit Restriktionsenzymen

- Auffüllen von 5’überhängenden DNA-Enden mit dem Klenow-Enzym

- Ligation und Subklonierung von DNA-Fragmenten

- Herstellung kompetenter Bakterien

- Transformation von kompetenten Bakterien mit Plasmid-DNA

- Präparation von Plasmid-DNA im analytischen Maßstab (Minipräparation)

- Photometrische Quantifizierung von Nukleinsäuren

- Agarose-Gelelektrophorese von DNA

\section{Methoden zur Isolierung von Nukleinsäuren}

\subsection{Minipräparation von Plasmid-DNA}

(Sambrook et al., 1989)

Diese Methode dient der schnellen Isolierung von kleinen Mengen Plasmid-DNA, wobei die Qualität der DNA für eine Restriktionsanalyse sowie für die Sequenzierung ausreichend ist. 5 ml LB-Medium (mit $50 \mu \mathrm{g} / \mathrm{ml}$ Antibiotikum) wurden mit einer Einzelkolonie angeimpft und über Nacht bei $37^{\circ} \mathrm{C}$ unter Schütteln inkubiert. Danach wurden $1.5 \mathrm{ml}$ Bakteriensuspension in 
ein Eppendorfgefäß transferiert und bei 12000x g für $30 \mathrm{sec}$ abzentifugiert. Das Pellet wurde in $100 \mu 1$ Resuspension-Lösung resuspendiert. Durch Zugabe von $200 \mu 10.2 \mathrm{M} \mathrm{NaOH}$ und 1\% SDS wurden die Zellen aufgebrochen. Nach einer Inkubationszeit von 5 min auf Eis wurde die Suspension mit Neutralisierungspuffer (3 M KAc, pH 5.5) gemischt und für weitere $10 \mathrm{~min}$ auf Eis inkubiert. Die Zelltrümmer wurden durch eine Zentrifugation bei 12000x g für 20 min und $4^{\circ} \mathrm{C}$ pelletiert. Der Überstand wurde in ein neues Eppendorfgefäß überführt und zur Extraktion mit 1 Vol. Phenol/Chloroform gemischt. Durch Zentrifugation bei 12000x g für 3 min bei RT wurden Proteine und Membranbestandteile von der Plasmidhaltigen Phase getrennt. Die obere Phase wurde abgenommen und in ein frisches Eppendorfgefäß überführt. Die Fällung der Plasmid-DNA erfolgte durch Zugabe von 2.5 Vol. $100 \%$ Ethanol für 15 min bei $-70^{\circ} \mathrm{C}$. Durch den anschließenden Zentrifugationsschritt mit 12000x g für 15 min bei $4^{\circ} \mathrm{C}$ wurde die DNA pelletiert. Das Pellet wurde mit $70 \%$ Ethanol gewaschen, luftgetrocknet und in $50 \mu \mathrm{H}_{2} \mathrm{O}$ aufgenommen.

\subsection{Plasmid-Minipräparation nach Qiagen-Protokoll}

Diese Methode wurde hauptsächlich bei zu sequenzierenden Plasmid-Proben angewendet, um eine hohe Ausbeute an Plasmid-DNA zu erzielen. Alle Schritte zur Isolierung der PlasmidDNA wurden dem Protokoll der Firma Qiagen entnommen. Die Ausbeute an Plasmid-DNA betrug 10-15 $\mu \mathrm{g}$ hochreine Plasmid-DNA.

\subsection{Maxipräparation von Plasmid-DNA}

Zur Isolation größerer Mengen hochreiner Plasmid-DNA wurde der JETSTAR Plasmid Midi Kit $^{\prime}$ (Genomed, Bad Oeynhausen) verwendet. Die mit dieser Methode isolierte Plasmid-DNA kann u.a. für Restriktionsanalysen, Hybridisierungsexperimente, zur Subklonierung oder Sequenzierung eingesetzt werden. Das Verfahren beinhaltet eine modifizierte Form der alkalischen Lyse (Birnboim und Doly, 1979) zur Präparation eines zellfreien Lysates sowie eine affinitätschromatographische Aufreinigung der DNA durch eine Säule aus dem Kit 
(Genomed, Bad Oeyenhausen).

$100 \mathrm{ml}$ LB-Medium mit Antibiotika wurden mit einer Einzelkolonie angeimpft und über Nacht bei $37^{\circ} \mathrm{C}$ unter Schütteln inkubiert. Die Bakteriensuspension wurde in $250 \mathrm{ml}$ Polypropylen-Zentrifugenröhrchen für $10 \mathrm{~min}$ bei $4^{\circ} \mathrm{C}$ und $4000 \mathrm{x}$ g zentrifugiert (Beckmannzentrifuge, Rotor JS7.5), der Überstand dekantiert und das Pellet in $4 \mathrm{ml}$ Puffer E1 resuspendiert. Durch Zugabe von 4 ml Puffer E2 wurden die Zellen lysiert, sowie Proteine und DNA durch die alkalischen Bedingungen denaturiert. Durch die im Puffer E1 enthaltene RNase wurde bakterielle RNA degradiert. Zur Vermeidung irreversibler Denaturierung der Plasmid-DNA wurde der Ansatz maximal 5 min bei RT inkubiert. Nach erfolgter Neutralisierung durch Zugabe von $4 \mathrm{ml}$ Puffer E3 wurden Proteine und genomische DNA in Detergenz-Komplexen gebunden, während die Plasmid-DNA aufgrund ihrer kovalent geschlossenen zirkulären Form schneller renaturierte und in Lösung blieb. Um die Zelltrümmer und die ausgefällten Salzkomplexe zu sedimentieren, wurde der Ansatz für 10 min mit $>15000 \mathrm{x}$ g bei $20^{\circ} \mathrm{C}$ zentrifugiert. Der Überstand wurde auf eine $10 \mathrm{ml}$ Puffer E4 äquilibrierte Säule gegeben und die Säule zweimal mit jeweils $10 \mathrm{ml}$ Puffer E5 gewaschen. Die an das Säulenmaterial gebundene Plasmid-DNA wurde durch Erhöhung der Salzkonzentration und des $\mathrm{pH}$-Wertes mit $5 \mathrm{ml}$ Puffer E6 eluiert. Die DNA wurde aus dem Eluat durch Zugabe von $3.5 \mathrm{ml}$ Isopropanol gefällt, abzentrifugiert, mit 70\%igem Ethanol gewaschen, $10 \mathrm{~min}$ bei RT getrocknet und in 100-200 $\mu \mathrm{l}$ $\mathrm{H}_{2} \mathrm{O}$ aufgenommen. Die DNA-Konzentration wurde photometrisch bestimmt.

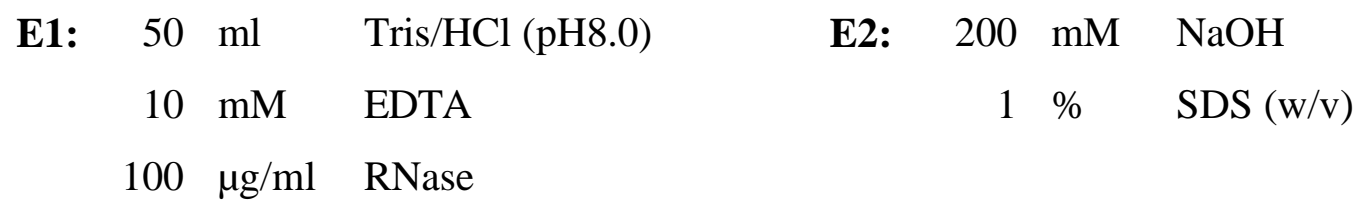

\begin{tabular}{|c|c|c|c|c|c|c|}
\hline E3: & M & K-Acetat (pH 5.5) & E4: & 600 & $\mathrm{mM}$ & $\mathrm{NaCl}$ \\
\hline 100 & $\mathrm{mM}$ & Tris/HCl (pH 8.0) & & 100 & $\mathrm{mM}$ & $\mathrm{NaAc}(\mathrm{pH} 5.0)$ \\
\hline & & & & 0.15 & $\%$ & Triton X-100 \\
\hline
\end{tabular}

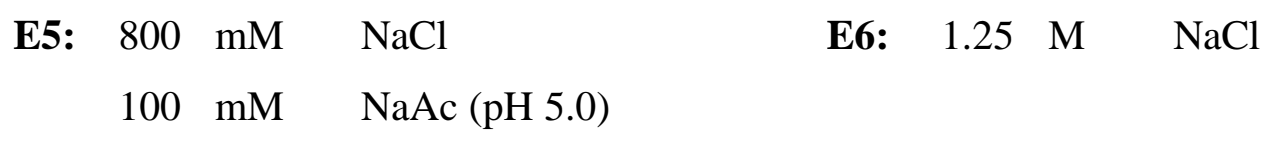

\subsection{Maxipräparation von Plasmid-DNA über einen CsCl-Gradienten}


Diese Methode wurde angewendet, um qualitativ hochwertige Plasmid-DNA für die 'in situHybridisierung' zu präparieren. 200 ml LB-Medium wurden mit einer Einzelkolonie angeimpft und über Nacht bei $37^{\circ} \mathrm{C}$ unter Schütteln inkubiert. Danach wurden die Bakterien bei $6000 \mathrm{x} \mathrm{g}\left(4^{\circ} \mathrm{C}\right)$ für 15 min sedimentiert. Das Zell-Pellet wurde in $6 \mathrm{ml}$ GET-Lösung, die $30 \mathrm{mg}$ Lysozym enthielt, resuspendiert und $10 \mathrm{~min}$ bei RT inkubiert. Nach Zugabe von $5 \mathrm{ml}$ GET-Lösung und $20 \mathrm{ml} \mathrm{NaOH} / \mathrm{SDS}$-Lösung wurde die Suspension für $15 \mathrm{~min}$ auf Eis inkubiert und mit $10 \mathrm{ml}$ KAc versetzt. Nach 20 min Inkubationszeit auf Eis wurde der Ansatz für 10 min bei 10400x g (Beckmann, Rotor JS 7.5) zentrifugiert. Der Überstand wurde dekantiert, mit 0.7 Vol. Isopropanol für $30 \mathrm{~min}$ bei RT gefällt, auf zwei PolyallomerZentrifugenröhrchen aufgeteilt und für $10 \min \left(4^{\circ} \mathrm{C}\right)$ bei $12100 \mathrm{x} g$ zentrifugiert. Anschließend wurde das Pellet in $8 \mathrm{ml} \mathrm{1x}$ TE-Puffer gelöst und mit $8 \mathrm{~g} \mathrm{CsCl}$ und 200 $\mu 1$ Ethidiumbromid (10 mg/ml) versetzt, in Quick-Seal-Röhrchen überführt und für $17 \mathrm{~h}$ bei 248000x g $\left(20^{\circ} \mathrm{C}\right)$ zentrifugiert. Die Plasmid-Bande wurde unter UV-Licht mit einer $1 \mathrm{ml}$ Spritze abgezogen und dreimal mit 1 Vol. Butanol extrahiert. Die Plasmid-DNA wurde mit 3 Vol. 100\% Ethanol 15 min bei RT ausgefällt, auf Eppendorfgefäße verteilt und $10 \mathrm{~min}$ bei 13000x g pelletiert. Das Pellet wurde nach zweimaligem Waschen mit 70\% Ethanol getrocknet und in $\mathrm{H}_{2} \mathrm{O}$ aufgenommen.

\subsection{Isolierung von Phagen-DNA}

Zur Vermehrung der Phagen wurde zunächst ein Phagen-Minilysat hergestellt. Dazu wurden $2 \mathrm{ml}$ einer frischen Wirtsbakterienkultur mit $100 \mu \mathrm{l}$ Phagenlösung für $20 \mathrm{~min}$ bei $37^{\circ} \mathrm{C}$ infiziert und in $12 \mathrm{ml} \mathrm{LB}-$ Medium mit $10 \mathrm{mM} \mathrm{MgCl}_{2}$ und $0.2 \%$ Maltose überführt. Nach weiterer Inkubation bei $37^{\circ} \mathrm{C}$ und vollständiger Lyse wurden die Phagenpartikel durch Zugabe von $100 \mu \mathrm{l}$ Chloroform (10 min weiteres Schütteln) aus den Bakterien freigesetzt. Durch Zentrifugation für 5 min mit 12000x g wurden die Bakterienzellreste sedimentiert und das im Überstand befindliche Phagen-Lysat wurde bis zur weiteren Verwendung bei $4^{\circ} \mathrm{C}$ gelagert. Zur Herstellung eines Phagen-Maxilysats wurden zunächst 200 ml LB-Medium/ 10 $\mathrm{mM} \mathrm{MgCl} 2$ mit $2 \mathrm{ml}$ der entsprechenden Bakterienkultur angeimpft und bis zur $\mathrm{OD}_{600}=0.5$ 
bei $37^{\circ} \mathrm{C}$ inkubiert. Daraufhin wurden dem Ansatz $5 \mathrm{ml}$ Phagen-Lysat zugesetzt und die vollständige Lyse der Bakteriensuspension nach 3-5 h bei $37^{\circ} \mathrm{C}$ erreicht. Durch Zugabe von $400 \mu \mathrm{l}$ Chloroform und 10 min weitere Inkubation bei $37^{\circ} \mathrm{C}$ wurden die Bakterien abgetötet und für 10 min bei $6000 \mathrm{x} \mathrm{g}\left(4^{\circ} \mathrm{C}\right)$ sedimentiert. Die im Überstand befindliche Bakterien DNA bzw. -RNA wurden durch mit $800 \mu \mathrm{l}$ DNase- und RNase- enthaltenden Puffer L1 für $1 \mathrm{~h}$ bei $37^{\circ} \mathrm{C}$ im Wasserbad inkubiert. Nach Zugabe von $50 \mathrm{ml}$ eiskaltem Puffer L2 wurde der Ansatz vorsichtig gemischt, $1 \mathrm{~h}$ auf Eis oder über Nacht bei $4^{\circ} \mathrm{C}$ für 15 min schüttelnd inkubiert, und anschließend die komplexierten Phagenpartikel mit $6000 \mathrm{x}$ g bei $4^{\circ} \mathrm{C}$ für 15 min sedimentiert. Das Phagenpellet wurde in $9 \mathrm{ml}$ Puffer L3 resuspendiert. Dem Ansatz wurden $9 \mathrm{ml}$ Puffer L4 zugegeben, anschließend $20 \mathrm{~min}$ bei $70^{\circ} \mathrm{C}$ im Wasserbad inkubiert, auf Eis abgekühlt, $9 \mathrm{ml}$ Puffer L5 vorsichtig zugemischt und $30 \mathrm{~min}$ mit $15000 \mathrm{x}$ g bei $4^{\circ} \mathrm{C}$ zentrifugiert. Der Überstand wurde in ein neues Reaktionsgefäß überführt und erneut für 10 min mit 15000x g bei $4^{\circ} \mathrm{C}$ zentrifugiert. Das partikelfreie Phagenlysat wurde auf eine mit $10 \mathrm{ml}$ Puffer QBT äquilibrierte Säule (Quiagen-Tip 500) aufgetragen, mit 30 ml Puffer QC gewaschen und mit $12 \mathrm{ml}$ Puffer QF eluiert. Die freigesetzte Phagen-DNA wurde nach Dilution mit $600 \mu_{1} \mathrm{H}_{2} 0$ durch 0.7 Vol. Isopropanol ausgefällt und durch Zentrifugation (10 min, 10000x g, 20 $\left.{ }^{\circ} \mathrm{C}\right)$ pelletiert. Die gewonnene Phagen-DNA wurde zweimal mit 70\% Ethanol gewaschen, bei RT getrocknet und in 50-100 $\mu 1 \mathrm{H}_{2} 0$ aufgenommen.

\begin{tabular}{|c|c|c|c|c|c|c|c|}
\hline Phagen- & 10 & $\mathrm{mM}$ & $\mathrm{MgCl}_{2}$ & L1: & 300 & $\mathrm{mM}$ & $\mathrm{NaCl}$ \\
\hline \multirow[t]{5}{*}{ Lösung: } & 10 & $\mathrm{mM}$ & Tris/HCl (pH 7.5) & & 100 & $\mathrm{mM}$ & Tris/HCl (pH 7.5) \\
\hline & 0.1 & $\mathrm{mM}$ & EDTA & & 10 & $\mathrm{mM}$ & EDTA \\
\hline & & & & & 0.2 & $\mathrm{mg} / \mathrm{ml}$ & BSA \\
\hline & & & & & 20 & $\mathrm{mg} / \mathrm{ml}$ & RNase A \\
\hline & & & & & 6 & $\mathrm{mg} / \mathrm{ml}$ & DNase I \\
\hline \multirow[t]{3}{*}{ L2: } & 30 & $\%$ & PEG 6000 & L3: & 100 & $\mathrm{mM}$ & $\mathrm{NaCl}$ \\
\hline & 3 & M & $\mathrm{NaCl}$ & & 100 & $\mathrm{mM}$ & Tris/HCl (pH 7.5) \\
\hline & & & & & 25 & $\mathrm{mM}$ & EDTA \\
\hline L4: & 4 & $\%$ & SDS & L5: & 3 & M & KAc (pH 5.5) \\
\hline QBT: & 750 & $\mathrm{mM}$ & $\mathrm{NaCl}$ & QC: & 1 & M & $\mathrm{NaCl}$ \\
\hline
\end{tabular}




$\begin{array}{rlllll}50 & \mathrm{mM} & \text { MOPS (pH 7.0) } & 50 & \mathrm{mM} & \text { MOPS (pH 7.0) } \\ 15 & \% & \text { Ethanol } & 15 & \% & \text { Ethanol } \\ 0.15 & \% & \text { Triton X-100 } & & & \end{array}$

QF: $\begin{array}{rll}1.25 & \mathrm{M} & \mathrm{NaCl} \\ 50 & \mathrm{mM} & \text { Tris/HCl }(\mathrm{pH} \mathrm{8.5)} \\ 15 & \% & \text { Ethanol }\end{array}$

\subsection{Isolierung genomischer DNA aus Organen}

Die Isolierung genomischer DNA aus der Schwanzspitze von Mäusen bzw. aus kultivierten Zellen für eine anschließende Genotypisierung wurde nach der Methode von Laird et al. (1991) durchgeführt.

1-2 cm der Schwanzspitze von etwa 3 Wochen alten Mäusen wurden in $700 \mu$ l Lyis-Puffer unter Zugabe von Proteinase K $(10 \mathrm{mg} / \mathrm{ml})$ bei $55^{\circ} \mathrm{C}$ über Nacht unter Schütteln inkubiert. Nach einer Phenol/Chloroform-Extraktion wurde die DNA mit $500 \mu$ Isopropanol bei RT präzipitiert und durch eine anschließende Zentrifugation mit 12000x g bei RT für $10 \mathrm{~min}$ pelletiert. Nach einem Waschschritt mit $500 \mu \mathrm{l}$ 70\%igem Ethanol wurde das DNA-Pellet in 100-200 $\mu \mathrm{l} \mathrm{H}_{2} \mathrm{O}$ gelöst und bis zur Analyse bei $4^{\circ} \mathrm{C}$ gelagert.

\subsection{Isolierung von Gesamt-RNA aus Geweben (modifiziert nach Chomczynski und Sacchi, 1987)}

Alle Glaswaren und Lösungen, die für die Experimente mit RNA benutzt wurden, wurden mit $0.1 \%$-igem DEPC für $12 \mathrm{~h}$ behandelt, um sie von RNasen zu befreien. Zur Zerstörung des DEPC wurden Glaswaren und Lösungen anschließend für 20 min autoklaviert. $100 \mathrm{mg}$ frisches Gewebe wurde in ein 15 bzw. 50 ml Falcon-Gefäß mit 1 ml RNA-NOW-Lösung (Biomol, Hamburg) gegeben. Das Gewebe wurde mit einem Dispergierwerkzeug (Ultraturrax 
T25, Schütt, Göttingen) homogenisiert und die Suspension 5 min auf Eis inkubiert. Nach Zugabe von 0.2 Vol. vorgekühltem Chloroform wurde der Ansatz vorsichtig geschwenkt und für weitere $5 \mathrm{~min}$ auf Eis inkubiert. Die Probe wurde dann mit $4000 \mathrm{x}$ g bei $4^{\circ} \mathrm{C}$ für $10 \mathrm{~min}$ zentrifugiert. Der wässrige Überstand wurde zur Fällung der RNA mit 1 Vol. Isopropanol auf Eis für 10 min inkubiert und die RNA anschließend durch Zentrifugation $\left(20 \mathrm{~min}, 4^{\circ} \mathrm{C}\right.$, 10000 x g) pelletiert. Danach wurde das RNA-Pellet in 70\% Ethanol resuspendiert, erneut sedimentiert und in DEPC- $\mathrm{H}_{2} \mathrm{O}$ gelöst. Die isolierte RNA konnte für die Gewinnung von Poly(A)+-RNA und Northern-Blot-Analysen eingesetzt werden. Nach der Konzentrationsbestimmung wurde die RNA in $20 \mu \mathrm{g}$-Aliquots aufgeteilt und bis zur weiteren Verwendung bei $-70^{\circ} \mathrm{C}$ aufbewahrt.

\subsection{Isolierung von Poly (A)+-RNA}

Die Anreicherung der Poly(A)+-RNA (ca. 1-5\% der Gesamt-RNA) erfolgte mit Hilfe des Dynabeads mRNA-Kits (Dynal, Hamburg). Das Prinzip der Methode beruht auf der Hybridisierung des Poly (A)-Schwanzes der mRNA mit Dynabeads Oligo (dT) ${ }_{25}$. Mit Hilfe eines Magneten wird die gebundene mRNA separiert.

$200 \mu \mathrm{l}(1 \mathrm{mg})$ Dynabeads Oligo $(\mathrm{dT})_{25}$ wurden in einem Reaktionsgefäß in den Magnetständer eingebracht. Nach 30 Sekunden wurde der Überstand abgenommen und die Dynabeads mit $100 \mu 1$ 2x Bindungspuffer gewaschen. Das Reaktionsgefäß wurde dann aus dem Magnetständer herausgenommen. Die Gesamt-RNA (75 $\mu \mathrm{g})$ wurde mit DEPC- $\mathrm{H}_{2} \mathrm{O}$ auf ein Gesamtvolumen von $100 \mu$ gebracht. Die RNA wurde 2 min bei $65^{\circ} \mathrm{C}$ denaturiert und auf Eis abgekühlt. Anschließend wurde die RNA zusammen mit $100 \mu$ 2x Bindungspuffer zu den Dynabeads gegeben und 5 min bei RT inkubiert. Das Reaktionsgefäß wurde dann in den Magnetständer eingebracht und nach 30 Sekunden wurde der Überstand entfernt. Die an die Dynabeads gebundene RNA wurde durch die Bindung der Dynabeads an den Magneten im Reaktionsgefäße zurückgehalten. Anschließend wurde zweimal mit $200 \mu 1$ Waschpuffer gewaschen. Das Reaktionsgefäß wurde wieder aus dem Magnetständer herausgenommen, und die RNA wurde durch die Zugabe von $15 \mu$ l Elutionspuffer und Erhitzen auf $65^{\circ} \mathrm{C}$ von den Dynabeads eluiert. Das Reaktionsgefäß wurde sofort 
wieder in den Magnetständer gestellt, wodurch die Dynabeads wieder von dem Magneten gebunden wurden und der Überstand, der die mRNA enthielt, abgenommen werden konnte.

\subsection{Konzentrationsbestimmung von DNA und RNA}

Die exakte Konzentrationsbestimmung von Nukleinsäure ist für die Durchführung der meisten molekularbiologischen Analysen unabdingbar. Die Konzentrationen wurden mit einem Spektralphotometer (Typ 8452 A, Hewlett Packard, Hamburg) bestimmt. Nach Abgleichen der Nullwerte konnte das Absorptionsmaximum der gemessenen Nukleinsäuren (bei $260 \mathrm{~nm}$ ) bestimmt und gleichzeitig Verunreinigungen durch Proteine (bei $280 \mathrm{~nm}$ ) bzw. Salze (bei $230 \mathrm{~nm}$ ) festgelegt werden. Die Berechnung der Nukleinsäurekonzentration wurde nach folgender Formel durchgeführt:

$$
\begin{gathered}
C[\mu g / \mu l]=\left(E_{260}-E_{320}\right) \times f \times c \\
C=\text { Konzentration der gemessenen Probe } \\
E=\text { Extinktion } \\
f=\text { Verdünnungsfaktor }=\text { Konzentration }_{\text {standard } / \text { Extinktion }} \text { standard } \\
\quad \text { für doppelsträngige DNA: c }=0.05 \mu \mathrm{g} / \mu \mathrm{l} \\
\quad \text { für einzelsträngige DNA: c }=0.025 \mu \mathrm{g} / \mu \mathrm{l} \\
\quad \text { für RNA: c }=0.04 \mu \mathrm{g} / \mu \mathrm{l} \\
E_{230}=\text { Absorptionsmaximum von Salzen } \\
E_{260}=\text { Absorptionsmaximum von DNA/RNA } \\
E_{280}=\text { Absorbtionsmaximum vieler Proteine } \\
E_{320}=\text { Nullwert }
\end{gathered}
$$

Der Quotient $E_{260} / E_{280}$ ist ein Maß für die Reinheit der DNA und sollte $2.0 \pm 0.2$ betragen. 


\section{Enzymatische Modifikation von DNA: Klonierungstechniken}

\subsection{Restriktionsenzymatische Spaltung von DNA}

Restriktionsendonukleasen erkennen spezifische Nukleotid-Sequenzen (4-8 bp) und spalten endonukleolytisch. Die Spaltung von DNA durch die Restriktionsendonukleasen wurde in einem Volumen von mindestens $20 \mu \mathrm{l}$ bei der enzymspezifischen Temperatur für 2-15 h durchgeführt, wobei pro $\mu \mathrm{g}$ DNA 5-10 U des jeweiligen Restriktionsenzyms eingesetzt wurden. Für Doppelspaltungen wurde entweder ein für beide Enzyme geeigneter Puffer genommen, oder es wurde zunächst nach Verdauung des ersten Enzyms ausgefällt, die DNA in $\mathrm{H}_{2} \mathrm{O}$ gelöst und mit dem zweiten Restriktionsenzym geschnitten. Die so gespaltene DNA wurde anschließend für weiterführende Analysen, wie z.B. gelektrophoretische Auftrennungen, Isolierungen von DNA-Fragmenten etc. verwendet.

\subsection{Dephosphorylierung von Plasmid-DNA}

Um eine Religation von Vektor-DNA (die nur mit einem Enzym geschnitten ist) während der nachfolgenden Ligation zu verhindern, wurde das Plasmid dephosphoryliert. Dazu wurde nach der Restriktionsspaltung $1 \mathrm{U}$ alkalische Phosphatase direkt zum Verdauungsansatz gegeben. Nach einstündiger Inkubation bei $37^{\circ} \mathrm{C}$ wurde anschließend das Enzym inaktiviert (10 min bei $\left.70^{\circ} \mathrm{C}\right)$. Die dephosphorylierte DNA wurde durch eine Phenol/ChloroformBehandlung aufgereinigt und mit 2.5 Vol. Ethanol und 1/10 Vol. $3 \mathrm{M} \mathrm{NaAc}(\mathrm{pH} 4.8$ ) ausgefällt. Anschließend wurde das Pellet in einer Endkonzentration von $50 \mathrm{ng} / \mu \mathrm{l}$ in 1x TE aufgenommen. 


\subsection{Ligation eines DNA-Inserts in einen Plasmid-Vektor}

Die geschnittenen, isolierten und nötigenfalls dephosphorylierten DNA-Fragmente konnten direkt in die komplementären Restriktionsschnittstellen des Plamid-Vektors ligiert werden. Für den Ligationsansatz wurden 30 ng Vektor-Plasmid-DNA, 30-120 ng DNA-Insert, $1 \mu 1$ 10x Ligationspuffer, $1 \mu 110 \mathrm{mM}$ ATP und $1 \mu \mathrm{T} \mathrm{T}_{4}$ DNA-Ligase $(5 \mathrm{U} / \mathrm{ml})$ eingesetzt. Der Ansatz wurde entweder $3 \mathrm{~h}$ bei RT oder über Nacht bei $16^{\circ} \mathrm{C}$ inkubiert.

\subsection{Herstellung kompetenter Bakterien für die Transformation}

(Dagert und Ehrlich, 1979)

$200 \mathrm{ml} \mathrm{LB}-M e d i u m$ wurden mit $2 \mathrm{ml}$ einer Bakterienkultur angeimpft und bei $37^{\circ} \mathrm{C}$ unter Schütteln (Certomat H Rundschüttler, Braun, Melsungen) bis zu einer $\mathrm{OD}_{600}=0.5$ vermehrt. Die Kultur wurde für $30 \mathrm{~min}$ auf Eis gestellt und dann bei $13000 \mathrm{x}$ g für 15 min bei $4^{\circ} \mathrm{C}$ zentrifugiert. Das Pellet wurde vorsichtig in $100 \mu \mathrm{l}$ eiskaltem $100 \mathrm{mM} \mathrm{CaCl} 2$ resuspendiert und 60 min auf Eis inkubiert. Durch die Behandlung der Zellen mit $\mathrm{CaCl}_{2}$ werden die Zellmembran durchlässiger. Nach erneutem Abzentrifugieren wurde das Pellet in $10 \mathrm{ml}$ eiskaltem $100 \mathrm{mM} \mathrm{CaCl} 2$ und 20\% Glycerin aufgenommen. Die Bakteriensuspension wurde in Reaktionsgefäße aliquotiert, in flüssigem Stickstoff schockgefroren und bei $-70^{\circ} \mathrm{C}$ bis zur Transformation gelagert.

\subsection{Transformation von Bakterien}

(nach Hanahan, 1985)

Zur Transformation der Bakterien mit den Plasmiden wurden die kompetenten Zellen zunächst auf Eis langsam aufgetaut. Danach wurde der Ligationsansatz mit $200 \mu \mathrm{l}$ der kompetenten Bakterien gemischt und für 30 min auf Eis inkubiert. Dann wurde der Ansatz für $90 \mathrm{sec}$ bei $42^{\circ} \mathrm{C}$ erhitzt. Nach 2 min Inkubation auf Eis wurde der Transformationsansatz 
mit $1 \mathrm{ml} \mathrm{LB}$-Medium versetzt und für 60 min bei $37{ }^{\circ} \mathrm{C}$ unter Schütteln inkubiert. Danach wurden 150-200 $\mu 1$ der transformierten Bakterien auf eine X-Gal-Platte ausgestrichen und über Nacht bei $37^{\circ} \mathrm{C}$ im Brutschrank inkubiert.

\section{Gelelektrophorese von Nukleinsäuren}

Die durch Restriktionsendonukleasen gespaltene DNA wird im elektrischen Feld aufgetrennt. Die Wanderungsgeschwindigkeit der Fragmente hängt von deren Größe, der angelegten Spannung, der Agarosekonzentration sowie der Pufferzusammensetzung und der Pufferkonzentration ab.

\subsection{Horizontalgelelektrophorese}

Die horizontale Gelelektrophorese wurde hauptsächlich zur Auftrennung restringierter, rekombinanter DNA, zur Insertisolierung spezifischer DNA-Fragmente oder zur Kontrolle von PCR-Produkten verwendet. Dazu wurde die Agarose in $100 \mathrm{ml}$ 1x TBE-Puffer (oder 1x TAE) durch Kochen gelöst, auf $60^{\circ} \mathrm{C}$ abgekühlt und in die vorgefertigten Gelträger überführt. Vorher wurde der Agaroselösung $4 \mu \mathrm{l}$ Ethidiumbromid (10 mg/ml) zugesetzt, ein Fluoreszenzfarbstoff, dessen flaches, mehrgliedriges Ringsystem zwischen benachbarten Basenpaaren interkaliert und so eine Sichtbarmachung unter UV-Licht ermöglicht. Nach vollständiger Verfestigung des Gels wurde die Elektrophorese in einer mit 1x Laufpuffer gefüllten Gelkammer bei konstanter Voltzahl $(6-8 \mathrm{~V} / \mathrm{cm})$ durchgeführt. 


\subsection{Vertikalgelelektrophorese}

Die vertikale Gelelektrophorese wurde zur Auftrennung der enzymverdauten, genomischen DNA verwendet. Die geringe Dicke des Gels gewährleistet eine bessere Übertragung der DNA beim Blotten. Zum Abdichten der Innenkammer wurde ein 1.5\%-iges Sockelgel aus Agarose gegossen. Nach der Erhärtung der Agarose wurde ein 1\%-iges Gel darübergeschichtet. Als Elektrophoresepuffer wurde 1x E-Puffer benutzt. Die Elektrophorese wurde über Nacht bei 15-20 Volt unter ständigem Umwälzen (Peristaltikpumpe Ismatec Sa, Zürich) des Laufpuffers durchgeführt.

\subsection{Elektrophorese von RNA im Agarosegel}

(Maniatis et al., 1982)

Um die Rückbildung der Sekundärstruktur der RNA während der Gelelektrophorese $\mathrm{zu}$ verhindern, wurde dem 1\%-igen Agarosegel (gelöst in 1x E-Puffer) eine FormaldehydLösung zugesetzt (Endkonzentration: 6.6\%). Die RNA-Proben mußten vor der Auftrennung folgendermaßen behandelt werden:

$\mathrm{x} \mu \mathrm{l}$ RNA (= $20 \mu \mathrm{g}$ Gesamt-RNA, bzw. bis $1 \mu \mathrm{g}$ Poly(A) $\left.{ }^{+}-\mathrm{RNA}\right)$

$1 \mu 1$ 10x E-Puffer

$8 \mu \mathrm{l}$ deionisiertes Formamid

$3 \mu \mathrm{l}$ Formaldehyd (37\%-ige Lösung)

$20 \mu \mathrm{l}$ Gesamtansatz

Dieses Gemisch wurde dann bei $68^{\circ} \mathrm{C}$ für 10 min denaturiert und für 5 min auf Eis gestellt. Die RNA-Proben wurden mit 0.2 Vol. Stop-Mix I versetzt und mit 60 Volt bei $4^{\circ} \mathrm{C}$ (mit Pufferumwälzung) gelelektrophoretisch aufgetrennt. 


\subsection{Längenstandards}

Um die Größe der enzymatisch verdauten DNA-Fragmente bestimmen zu können, wurde parallel zu den DNA-Proben die Lambda-DNA (DNA-molecular weight marker III, BRL) auf das Elektrophoresegel aufgetragen. Dadurch konnte die Größe der durch Restriktion erhaltenen Fragmente festgestellt werden. Bei der Auftrennung von kleinen DNAFragmenten wurde der "1 kb DNA Ladder"-Längenstandard (BRL, Eggenstein) verwendet. Durch Vergleich der Bandenstärke von Längenstandard und DNA-Probe konnte die Konzentration der Probe abgeschätzt werden.

\section{Isolierung von DNA-Fragmenten aus einem Agarosegel}

\subsection{Isolierung von DNA-Fragmenten mit der "Geneclean"-Methode}

Die Isolierung von Restriktionsfragmenten aus einem Agarosegel erfolgte mit dem Jet-sorbKit' (Genomed, Bad Oeyenhausen). Die zu isolierende DNA-Bande wurde aus dem Gel geschnitten, das Gelstück gewogen und die entsprechenden Mengen an Puffer A1 und Glasmilch dazugegeben. Pro 100 mg Gelstück wurden $300 \mu$ Puffer A1 und $10 \mu$ l Glasmilch eingesetzt. Der Ansatz wurde $15 \mathrm{~min}$ bei $50^{\circ} \mathrm{C}$ inkubiert, wobei dieser alle 2 min gemischt wurde, um die Glasmilch in Suspension zu halten. Nach Anlagerung der DNA an die Glasmich wurde der Reaktionsansatz für $30 \mathrm{sec}$ bei 12000x g zentrifugiert (Eppendorfzentrifuge). Der Überstand wurde verworfen, das Pellet einmal in $500 \mu$ Puffer A1 gewaschen, um Agarosereste und andere Kontaminationen zu entfernen. Nach erneuter Zentrifugation wurde das Pellet zweimal mit jeweils $300 \mu$ Puffer A2 gewaschen, danach der Überstand abgenommen, das Pellet getrocknet und in $20 \mu 1 \mathrm{H}_{2} \mathrm{O}$ gelöst. Die DNA wurde 5 min bei $50^{\circ} \mathrm{C}$ eluiert, der Ansatz abzentrifugiert und der Überstand mit der darin enthaltenen DNA in ein neues Reaktionsgefäß überführt. Die typische Ausbeute an DNA-Fragmenten $>400$ bp lag bei ca. $70-80 \%$ (<400 bp, ca. $50 \%)$. 


\subsection{Isolierung von DNA-Fragmenten aus Polyacrylamidgelen}

Zunächst wurden die PCR-Produkte auf ein 5-8\%-iges Polyacrylamidgel aufgetragen und elektrophoretisch aufgetrennt. Die gewünschten PCR-Amplifikate wurden mit einem sterilen Skalpell aus dem Gel ausgeschnitten, in einem Eppendorfgefäß zermörsert und über Nacht bei $37^{\circ} \mathrm{C}$ in $500 \mu 1$ 1x TE-Puffer aus dem Gel eluiert. Durch Zentrifugation (20 min, 13000x $\mathrm{g}, 4^{\circ} \mathrm{C}$ ) wurden die Gelreste sedimentiert und die wässrige, DNA-enthaltende Phase mit 1 Vol. Phenol/Chloroform extrahiert. Der Überstand wurde mit 0.1 Vol. $3 \mathrm{M} \mathrm{NaAc}$ (pH 6.0) und 2.5 Vol. Ethanol versetzt und die DNA für 15 min bei $-70^{\circ} \mathrm{C}$ präpiziert. Nach einer erneuten Zentrifugation (20 min, 13000x g, $4^{\circ} \mathrm{C}$ ) wurde das DNA-Pellet mit 70\% Ethanol gewaschen, bei RT getrocknet und in 10-20 $\mu_{1} \mathrm{H}_{2} \mathrm{O}$ gelöst. Zur Bestimmung der Konzentration bzw. der Reinheit wurde die DNA auf ein 1-5\%-iges Agarosegel aufgetragen und gelelektrophoretisch analysiert.

\section{Transfertechniken von Nukleinsäuren}

\subsection{Transfer von DNA-Fragmenten: Southern-Blotting}

(Southern, 1975)

Mit Hilfe des Southern-Transfers werden DNA-Fragmente aus Agarosegelen auf Nitrocellulosemembranen übertragen. Nach der Elektrophorese wurde das Gel zuerst für 10 min in $500 \mathrm{ml}$ Depurinierungslösung $(0.25 \mathrm{M} \mathrm{HCl})$ eingelegt. Anschließend wurde es für 30 min in Denaturierungslösung überführt und dann für $30 \mathrm{~min}$ in Neutralisierungslösung behandelt. Das Gel wurde luftblasenfrei auf ein mit 20x SSC-Lösung getränktes Blottingpapier gelegt, welches in eine mit 20x SSC gefüllte Wanne eintauchte. Dieses Gel wurde von Plastikfolie so umschlossen, daß der kapillare Transport des 20x SSC nur durch das Gel erfolgen konnte. Ein Nitrocellulosefilter und zwei mit 2x SSC-Lösung getränkte Blottingpapiere wurden luftblasenfrei auf das Gel gelegt. Darauf wurden mehrere Schichten trockenes Papier gelegt und dann mit einem Gewicht (ca. 500 g) beschwert. Der Transfer 
erfolgte über Nacht. Während einer Transferzeit von 12-20 h wird die konzentrierte 20x SSC-Lösung von den trocken Papierschichten durch das Gel und die Nylonmembran gezogen, wobei die DNA diffundiert und an der Membran haften bleibt (Kapillartransfer). Anschließend wurde die Position der Geltaschen auf der Nitrocellulose markiert. Der Filter wurde vom Gel abgenommen und in 2x SSC-Lösung kurz gewaschen, 'crossgelinked' (120 J, UV Stratalinker 1800, Stratagene, Heidelberg) und zur Fixierung der DNA für $2 \mathrm{~h}$ bei $80^{\circ} \mathrm{C}$ gebacken.

\subsection{Transfer von RNA aus Agarosegelen (Northern-Blotting)}

Die RNA aus dem denaturierenden RNA-Gel wurde direkt nach der Elektrophorese ohne weitere Vorbehandlung auf einen Nitrocellulosefilter transferiert. Nach dem Transfer wurde die RNA in gleicher Weise wie die DNA an die Membran fixiert. RNA-Längenstandard enthaltende Spuren wurden vom Filter abgeschnitten, die RNA 15 min in 5\% Essigsäure auf der Membran fixiert und $10 \mathrm{~min}$ in Methylenblau (0.04\% in $0.5 \mathrm{M} \mathrm{NaAc}, \mathrm{pH} 5.2)$ angefärbt. Der Filter wurde unter fließendem Wasse entfärbt und luftgetrocknet.

\section{Radioaktive Markierung von DNA}

\section{1. "random priming"}

Zur radioaktiven Markierung von DNA-Sonden wurde die Methode des "random priming" (Feinberg und Vogelstein, 1983) verwendet. Diese Methode ermöglicht eine hohe Ausbeute an spezifisch radioaktiv markierten DNA-Sonden $\left(1-5 \times 10^{9} \mathrm{cpm} / \mu \mathrm{g}\right.$ DNA). Für die Markierung wurde der "Megaprime DNA LabellingTM-Kit" der Firma Amersham Buchler (Braunschweig) benutzt. Pro Ansatz wurden 5 bis 25 ng DNA und $40 \mu \mathrm{Ci}\left[\alpha_{-}{ }^{32} \mathrm{P}\right]-\mathrm{dCTP}$ eingesetzt. Die Konzentration von Random-Primer, Reaktionspuffer, dNTPs und KlenowEnzym richtete sich nach den Angaben des Herstellers. 


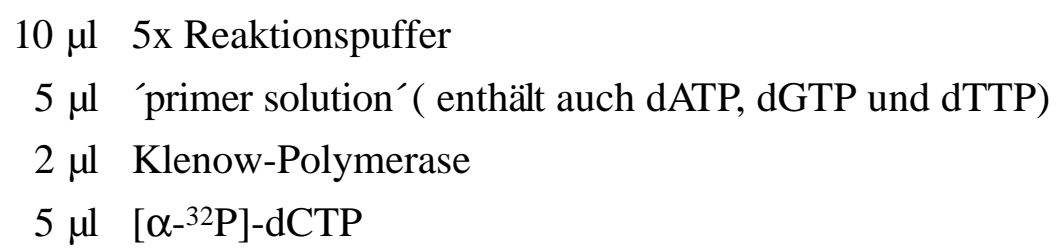

Zunächst wurde die doppelsträngige DNA für 5-10 min bei $100^{\circ} \mathrm{C}$ denaturiert. Mit Hilfe von Starter-Oligo $(\mathrm{dN})_{6}$, dNTPs, $\left[\alpha_{-}{ }^{32} \mathrm{P}\right]-\mathrm{dCTP}$ oder $\left[\alpha_{-}{ }^{32} \mathrm{P}\right]$-dATP und dem Klenow-Fragment der DNA-Polymerase I wurden die komplementären Stränge unter Einbau radioaktiver Nukleotide neu synthetisiert. Nach 45-60 min Inkubation bei $37^{\circ} \mathrm{C}$ wurde die Reaktion durch Zugabe von $3 \mu \mathrm{l}$ EDTA, $10 \mu \mathrm{l}$ tRNA, $11 \mu \mathrm{l} 3 \mathrm{M} \mathrm{NaAc}(\mathrm{pH} 6.0), 37 \mu \mathrm{H}_{2} \mathrm{O}$ und 280 $\mu 1$ Ethanol abgestoppt. Nach 30 min Fällung auf Eis und 15 min Zentrifugation bei 15000x g (Biofuge A, Heraeus, Osterode) wurde das Pellet mit $70 \%$ Ethanol gewaschen, bei $37^{\circ} \mathrm{C}$ getrocknet und in $200 \mu \mathrm{l} \mathrm{H}_{2} \mathrm{O}$ gelöst. Die spezifische Aktivität der DNA-Probe wurde im Szintillationszähler (Tri-Carb 4530, Packard Instruments, Warrenville, USA) gemessen. Sie liegt in der Regel zwischen 4 × $10^{8}$ und $5 \times 10^{9} \mathrm{cpm} / \mu \mathrm{g}$ DNA.

\subsection{Endmarkierung von Oligonukleotiden}

(Maniatis et al., 1982)

Die radioaktive 5'-Endmarkierung von Oligonukleotiden wurde mit Hilfe der T4Polynukleotidkinase durchgeführt. Der Ansatz wurde wie folgt erstellt:

$\begin{array}{cl}10 \text { pmol } & \text { Oligonukleotid } \\ 1 \mu \mathrm{l} & 10 \mathrm{x} \text { Kinase } \\ 5 \mu \mathrm{l} & {\left[\gamma^{32} \mathrm{P}\right] \text {-ATP }} \\ 10 \mathrm{U} & \text { Polynukleotidkinase }\end{array}$

Nach 45 minütiger Inkubation bei $37^{\circ} \mathrm{C}$ wurde das Reaktionsgemisch mit $0.5 \mathrm{M}$ EDTA (pH 8.0) abgestoppt, und anschließend wurde die Probe über eine NAP-50 Säule aufgereinigt. 


\subsection{Aufreinigung radioaktiver DNA-Sonden und sythetischer Oligonukleotide}

Die radioaktiven Sonden wurden durch Gelfiltration über eine Sephadex G-50 Medium Säule von Nukleotiden und niedermolekularen Substanzen getrennt. Hierfür wurde eine $1 \mathrm{ml}$ Spritze mit etwas Glaswolle gefüllt (bis maximal zur $0.1 \mathrm{ml}$ Marke) und das in TX-Puffer gelöste Sephadex G-50 Material in die Spritze gefüllt. Die Spritze wurde für 2 min bei 800x g zentrifugiert. Anschließend wurde das Eluat verworfen, die fertigen Säulen wurden in ein Reaktionsgefäß mit Schraubdeckelverschluß verbracht und mit diesem in ein $15 \mathrm{ml}$ Falcon-Gefäß gestellt. Dem Markierungsansatz $(50 \mu \mathrm{l})$ wurden $50 \mu \mathrm{H}_{2} \mathrm{O}$ zugesetzt, der Ansatz auf die Säule aufgetragen und anschließend nochmals 2 min bei 800x g zentrifugiert. Das radioaktive Eluat enthielt nunmehr die markierten Fragmente, während Primer und Nukleotide auf der Säule verblieben.

Oligonukleotide wurden über NAP5-Säulen (Phamacia) aufgereinigt. Dazu wurden die Säulen zweimal mit Ampuwa gespült, dem $50 \mu \mathrm{l}$ Reaktionsansatz $450 \mu \mathrm{H} \mathrm{H}_{2} \mathrm{O}$ zugeben und der gesamte Ansatz auf die Säule gegeben. Das radioaktiv markierte DNA-Fragment wurde dann mit $1 \mathrm{ml}$ Ampuwa in ein Schraubendeckelreaktionsgefäß eluiert.

\section{Hybridisierung radioaktiver Sonden an membrangebundene DNA oder RNA}

Die gebackenen Nitrocellulosefilter mit der gebundenen DNA bzw. RNA wurden für 10 min in 2x SSC-Lösung eingeweicht. Nach Füllung der Hybridisierungstubes mit 2x SSCLösung und Entfernung entstandener Luftblasen wurden die Filter mit $12 \mathrm{ml}$ Hybridisierungslösung I für mindestens $2 \mathrm{~h}$ bei entsprechender Temperatur, die je nach Homologiegrad zwischen eingesetzter DNA-Sonde und zu hybridisiernder DNA oder RNA zwischen $58-68^{\circ} \mathrm{C}$ gewählt wurde, im Rollerofen (Bachofer, Reutlingen) präinkubiert. Hiermit sollten unspezifische Bindungsstellen an den Filtern abgesättigt werden. Die radioaktiv markierte DNA-Probe und $200 \mu \mathrm{l}$ Lachsspermien-DNA $(10 \mathrm{mg} / \mathrm{ml}$, geschert durch Ultraschall) wurden durch 5-10 min Kochen denaturiert und dann auf Eis abgekühlt. Die 
benutzte Vorhybridisierungslösung wurde verworfen, und in die Hybridisierungstubes wurden $15 \mathrm{ml}$ frische Hybridisierungslösung mit der radioaktiv markierten Probe gegeben. Die Hybridisierung erfolgte über Nacht bei der entsprechenden Temperatur im Rollerofen. Nach Beendigung der Hybridisierung wurden die Filter 10 min mit 2x SSC bei RT und anschließend je nach gewünschter Stringenz bei einer Temperatur von $55^{\circ}-65^{\circ} \mathrm{C}$ gewaschen. Für eine geringe Stringenz wurde $2 \mathrm{x}$ mit Waschlösung $\mathrm{I}$ für $10 \mathrm{~min}$ und kurz mit Waschlösung II gewaschen, für eine höhere Stringenz wurde zusätzlich 2x 10 min mit Waschlösung II gewaschen. Die Filter wurden luftgetrocknet, in Folie eingelegt, in einer Röntgenfilmkassette befestigt und darauf Röntgenfilme (Hyperfilm ${ }^{\mathrm{TM}_{-} \mathrm{MP}}$, Amersham Buchler, Braunschweig) gelegt. Die Filme wurden für wenige Minuten bis zu mehreren Tagen bei $-70^{\circ} \mathrm{C}$ exponiert und im Entwicklungsgerät Gevamatic 110 U (Agfa Gevaert, München) entwickelt.

\section{Isolierung rekombinanter Klone aus einer Phagen-Bibliothek}

Zur Isolierung von Phagen-Klonen aus einer Phagen-Bibliothek wurden die folgenden Versuchsschritte durchgeführt:

1. Titerbestimmung der Phagen-Bibliothek

2. Ausplattieren der Phagen-Bibliothek

3. Transfer und Behandlung der Phagen auf Nitrocellulose

4. Hybridisierung der Phagen-DNA mit einer radioaktiven DNA-Probe

5. Anreicherung und Isolierung der positiven, rekombinanten Phagen

6. Maxipräparation der Phagen-DNA

\subsection{Titerbestimmung der Phagen-Bibliothek}

Zunächst wurden $10 \mathrm{ml}$ LB-Medium mit $10 \mu \mathrm{l} 1 \mathrm{M} \mathrm{MgCl}_{2}$ und $0.2 \%$ Maltose mit kompetenten Bakterien E.coli LE392 über Nacht bei $37^{\circ} \mathrm{C}$ in einem $50 \mathrm{ml}$ Falconröhrchen inkubiert. Für das Screening einer Phagenbibliothek muß eine genügend 
große Menge an Phagen ausplattiert werden. Um die entsprechende Menge an Phagenpartikeln einsetzten zu können, wird der aktuelle Titer der Phagensuspension bestimmt. Mit Hilfe von Phagenpuffer wurde eine Verdünnungsreihe aus einem Aliquot der Phagen-Bibliothek $\left(10^{-2}\right.$ bis $\left.10^{-6}\right)$ hergestellt. Die einzelnen Verdünnungsstufen wurden ausplattiert und über Nacht bei $37^{\circ} \mathrm{C}$ inkubiert. Durch Lyse der Bakterien entstanden charakteristische Phagenplaques ( $\mathrm{pfu}=$ plaque forming units), so daß anhand des Verdünnungsfaktors der Titer der Phagen-Bibliothek errechnet werden konnte.

\subsection{Ausplattieren der Phagen-Bibliothek}

Die $300 \mu$ l Bakterienlösung LE 392 wurden mit verdünnter Phagenkonzentration 30 min bei $37^{\circ} \mathrm{C}$ inkubiert. Anschließend wurde $10 \mathrm{ml} 45-50^{\circ} \mathrm{C}$ warmer TOP-Agarose dazugegeben und diese Mischung auf eine Agarplatte ausplattiert. Im Brutschrank wurden die Platten über Nacht bei $37^{\circ} \mathrm{C}$ inkubiert.

\subsection{Transfer und Behandlung der Phagen auf Nitrocellulosefilter}

Die Platten wurden aus dem Brutschrank genommen und für $1 \mathrm{~h}$ in den Kühlraum gestellt. Damit sollte verhindert werden, daß bei dem Transfer der Phagen auf die Filter BBL-Agar an den Filtern haften bleibt. Pro Platte wurden jeweils 2 Nitrocellulosefilter (Hanahan und Meselson, 1980) benötigt. Der 1. Filter wurde für $1 \mathrm{~min}$ bei RT auf die Platte gelegt. Die Position des Filters wurde mit einer Nadel markiert. Der 2. Filter wurde für ca. $10 \mathrm{~min}$ aufgelegt und an gleicher Stelle markiert. Die beide Filter wurden anschließend für ca. 3-5 min mit Denaturierungslösung, $10 \mathrm{~min}$ in Neutralisierungslösung und $10 \mathrm{~min}$ in 2x SSC eingeweicht (Benton und Davis, 1977). Nach dieser Behandlung wurden die Filter zum Trocknen auf Blottingpapier gelegt und anschließend für $2 \mathrm{~h}$ bei $80^{\circ} \mathrm{C}$ im Vakuumofen gebacken, damit die Phagen-DNA an die Nitrocellulose fixiert werden kann. Die Hybridisierung der Filter mit der radioaktiv markierten DNA-Probe wurde wie in Abschnitt II.15. durchgeführt. 


\subsection{Anreicherung und Isolierung der positiven, rekombinanten Phagen}

Positive Signale auf den Röntgenfilmen wurden dazu genutzt, um die entsprechenden Phagenplaques auf den Agarplatten zu identifizieren. In dem Bereich von 0.3-0.5 $\mathrm{cm}^{2}$ eines positiven Klons wurde der Agar mit einem Skalpell ausgeschnitten und in $600 \mu \mathrm{l}$ Phagenpuffer überführt. Um die restlichen Bakterien abzutöten, wurde $10 \mu \mathrm{l}$ Chloroform hinzugegeben. Das Gemisch wurde $1 \mathrm{~h}$ bei RT unter Schütteln inkubiert, damit die Phagen in den Phagenpuffer diffundieren konnten. Von dieser Suspension wurden Verdünngsreihen hergestellt. Das erste Rescreening sollte mit ca 1000-2000 pfu/Platte durchgeführt werden. Die nachfolgenden Schritte erfolgten wie unter II.16.2.3. beschrieben. Das Rescreening wurde solange durchgeführt, bis ein Einzelklon sicher isoliert werden konnte. Der identifizierte positive Phagenklon wurde mit einer blauen Pipettenspitze aus der Platte gepickt und in $200 \mu \mathrm{l}$ Phagenpuffer aufgenommen. Diese Phagenlösung wurde für die Herstellung des Phagen-Lysats und die Präparaton der Phagen-DNA verwendet.

\subsection{Anlegen eines Phgenstocks}

$200 \mathrm{ml} \mathrm{LB}$ mit $10 \mathrm{mM} \mathrm{MgCl}{ }_{2}$ wurden mit $35 \mu \mathrm{l}$ der Phagenlösung beimpft und bis zur Lyse geschüttelt. Das Lysat wurde wie unter II.9.5. bis zur Zugabe von Puffer L1 und anschließender Inkubation gleich behandelt. Anschließend wurde das Phagenpräzipitat pelletiert $\left(10000 \mathrm{x} \mathrm{g}, 15 \mathrm{~min}, 4^{\circ} \mathrm{C}\right)$ und in $2 \mathrm{ml}$ Phagenpuffer resuspendiert. Um das PEG zu entfernen, erfolgte eine Extraktion mit 1 Vol. Chloroform. Der Stock wurde über 100 $\mu \mathrm{l}$ Chloroform bei $4^{\circ} \mathrm{C}$ gelagert. Abschließend wurde eine Titerbestimmung durchgeführt. 


\section{Methoden der "Polymerase Chain Reaction" (PCR)}

(Saiki et al., 1985)

Mit der Methode der PCR können kleinste Mengen genetischen Materials amplifiziert und somit für weitere Untersuchungen zugänglich gemacht werden. Zwei synthetische Oligonukleotide, die den zu amplifizierenden Abschnitt der DNA flankieren, dienen als Primer für die Taq-Polymerase. Durch sich wiederholende Zyklen - Denaturierung der DNA, Annealing der Primer und Synthese des zweiten Stranges - wird der DNA-Abschnitt, der durch die beiden Primer begrenzt ist, amplifiziert. Dabei dient jeder neu gebildete Strang als Matrize für die Synthese eines weiteren, wodurch ein expontentieller Anstieg der Menge des gewünschten DNA-Abschnitts erreicht wird. Durch die Zugabe der hitzestabilen DNAPolymerase (Taq-Polymerase) des Archaebakteriums Thermus aquaticus (Chien et al., 1976) werden die spezifischen DNA-Stränge in 30-40 Zyklen in 106-facher Kopienzahl durch exponentielle Amplifikation erzeugt.

\subsection{PCR an Plasmid-DNA}

Die Methode wurde durchgeführt, um DNA-Fragmente $\mathrm{zu}$ amplifizieren, die durch restriktionsenzymatische Spaltung nicht isoliert werden konnten. Dazu wurde folgender Ansatz zusammenpipettiert:

$$
\begin{array}{rl}
\mathrm{x} \mu \mathrm{l} & \text { Template-DNA }(30-500 \mathrm{ng}) \\
2 \mu \mathrm{l} & \text { Primer } 1(10 \mathrm{pmol} / \mu \mathrm{l}, \text { sequenzspezifisch }) \\
2 \mu \mathrm{l} & \text { Primer } 2(10 \mathrm{pmol} / \mu \mathrm{l}, \text { sequenzspezifisch }) \\
2 \mu \mathrm{l} & \mathrm{dNTPs}(10 \mathrm{mM}) \\
5 \mu \mathrm{l} & \text { Taq-Polymerase Puffer }(10 \mathrm{x}) \\
0.5 \mu \mathrm{l} & \text { Taq-Polymerase }(5 \mathrm{U} / \mu \mathrm{l}, \text { Amersham }) \\
\text { ad } 50 \mu \mathrm{l} & \mathrm{ddH}_{2} \mathrm{O}
\end{array}
$$

Der Ansatz wurde mit Mineralöl überschichtet und 30-40 Zyklen der DNA-Amplifikation in einem Thermocycler (Perkin Elmer Cetus) unterworfen. Die Anzahl der Zyklen, die 
einzelnen Temperaturschritte und die jeweilige Dauer der Zyklen mußte für jedes DNAFragment und die dafür eingesetzten Primer neu gewählt werden. Der Reaktionsansatz wurde folgendem Programm im Thermocycler unterworfen:

\begin{tabular}{|l|l|l|}
\hline $30-60 \mathrm{sec}$ & $95^{\circ} \mathrm{C}$ & Denaturieung \\
\hline $30-90 \mathrm{sec}$ & $50-65^{\circ} \mathrm{C}$ & Annealing \\
\hline $30-90 \mathrm{sec}$ & $72^{\circ} \mathrm{C}$ & Elongation \\
\hline
\end{tabular}

Vor Beginn des ersten Cyclus wurde 3-5 min bei $95^{\circ} \mathrm{C}$ denaturiert und danach schloß sich ein letzter Elongationsschritt von 7 min bei $72^{\circ} \mathrm{C}$ an. Nach Abschluß der PCR wurden 1/10 des Ansatzes mit Stopmix II gemischt und je nach Größe des PCR-Produkts auf ein 1-1.5\%-iges Agarosegel aufgetragen und elektrophoretisch aufgetrennt.

\subsection{PCR an genomischer DNA}

Zur Amplifikation spezifischer Sequenzen von genomischer DNA wurde die DNA wie unter II.9.6 beschrieben extrahiert und mit folgenden Substanzen zu einem Reaktionsansatz zusammenpipettiert:

$$
\begin{aligned}
\text { x } \mu \mathrm{l} & \text { DNA }(300-500 \mathrm{ng}) \\
2 \mu \mathrm{l} & \text { Primer } 1(10 \mathrm{pmol} / \mu \mathrm{l}) \\
2 \mu \mathrm{l} & \text { Primer } 2(10 \mathrm{pmol} / \mu \mathrm{l}) \\
2 \mu \mathrm{l} & \text { dNTPs }(10 \mathrm{mM}) \\
5 \mu \mathrm{l} & \text { Taq-Polymerase Puffer }(10 \mathrm{x}) \\
0.5 \mu \mathrm{l} & \text { Taq-Polymerase }(5 \mathrm{U} / \mu \mathrm{l}, \text { Amersham }) \\
\text { ad } 50 \mu \mathrm{l} & \mathrm{dd}_{2} \mathrm{O}
\end{aligned}
$$




\section{3. "Reverse PCR" (RT-PCR)}

(Kogan et al., 1987)

Die Methode der reversen PCR basiert auf der Umschreibung von mRNA in cDNA (Synthese der komplementären DNA) und einer anschließenden PCR. Mit Hilfe der RTPCR können kleinste Transkriptmengen in Geweben detektiert werden.

$10 \mu \mathrm{g}$ Gesamt-RNA (II.9.7.) wurden mit 30 U DNase I (RNase-frei) $10 \mathrm{~min}$ bei $37^{\circ} \mathrm{C}$ inkubiert und im Vakuum-Konzentrator getrocknet. Das Pellet wurde in $10 \mu \mathrm{l}$ $\mathrm{H}_{2} \mathrm{O}$ gelöst. Für die cDNA-Synthese wurde $1 \mu$ l Primer (200 ng) zu der RNA dazugegeben, $10 \mathrm{~min}$ bei $70^{\circ} \mathrm{C}$ denaturiert und $15 \mathrm{~min}$ auf Eis inkubiert. $\mathrm{Zu}$ diesem Ansatz wurden folgende Komponenten dazugegeben:

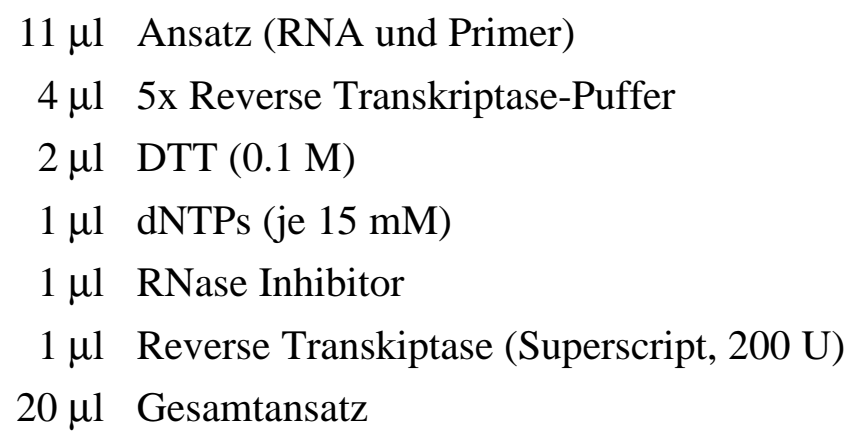

Der Reaktionsansatz wurde 10 min bei RT und $1 \mathrm{~h}$ bei $37^{\circ} \mathrm{C}$ inkubiert. Nach der cDNA Synthese wurde der Reaktionsansatz 1:10 mit $\mathrm{H}_{2} \mathrm{O}$ verdünnt und ein $1 \mu$ Aliquot davon in eine PCR eingesetzt. Die Konzentration der Primer, des Puffers und des Enzyms entsprachen den unter II.17.1. gemachten Angaben. Um die Spezifität des PCR-Produkts zu erhöhen, wurde eine Nachamplifikation mit einem internen Primer ('nested primer') und $1 \mu$ des ersten PCR-Produkts als Template durchgeführt. Hierbei wurde die 'Annealing'-Temperatur auf $60-62^{\circ} \mathrm{C}$ erhöht. Das PCR-Produkt wurde entweder nach Subklonierung oder direkt sequenziert. 


\section{MARATHON RACE-PCR}

\subsection{Konstruktion von MARATHON cDNA-Banken}

Für die Konstruktion von cDNA Banken wurde der MARATHON RACE Kit (Clontech) verwendet. Im Gegensatz zu Phagen-Banken wird bei dieser Methode der Screening-Prozeß rein über PCR durchgeführt. Nach einer Erst- und Zweitstrangsynthese nach dem Prinzip von Gubler und Hoffmann (1983) werden spezielle Linker an die doppelsträngige cDNA ligiert. Diese Primer sind partiell doppelsträngig mit einem glatten Ende und partiell einzelsträngig, wobei die zurückstehende 3'-OH-Gruppe durch eine Aminogruppe geblockt ist. Die Sequenz des einzelsträngigen Linkeranteils entspricht den Primern, die in der Screening PCR eingesetzt werden. Diese Linker-Primer finden erst eine Bindungsstelle, wenn durch Extension von genspezifischen Primern im Zuge des ersten PCR Cyclus diese geschaffen werden. Das Screenen der Bank wird dann mit Kombinationen von LinkerPrimern und genspezifischen Primern durchgeführt. In getrennten Reaktionen werden die 5'und 3'-Enden der gesuchten cDNA synthetisiert, aus denen dann in einer Fusions-PCR die gesamte cDNA konstruiert wird.

\subsection{Synthese der MARATHON cDNA-Banken}

Alle Reaktionen wurden nach dem Clontech MARATHON Protokoll und mit den Komponenten des Kits durchgeführt. Als Kontrolle wurde aus humaner Placenta Poly $(\mathrm{A})^{+}$RNA (im Kit enthalten) mitgeführt. Für die Erststrang-Synthese wurden

$$
\begin{array}{ll}
1 \mu \mathrm{l} & \text { Poly }(\mathrm{A})^{+} \text {RNA }(1 \mu \mathrm{g}) \\
1 \mu \mathrm{l} & \text { Erststrang-Primer (10 pmol ESP }) \\
3 \mu \mathrm{l} & \mathrm{H}_{2} \mathrm{O}
\end{array}
$$

gemischt und für 2 min bei $70^{\circ} \mathrm{C}$ inkubiert, dann 2 min auf Eis gehalten. Kondenswasser 
wurde abzentrifugiert und durch Zugabe von

$$
\begin{array}{ll}
2 \mu \mathrm{l} & \text { Erststrang-Synthese-Puffer } \\
1 \mu \mathrm{l} & \mathrm{dNTP}(10 \mathrm{mM}) \\
1 \mu \mathrm{l} & \mathrm{H}_{2} \mathrm{O} \\
1 \mu \mathrm{l} & \text { MMLV Reverse Transkriptase }
\end{array}
$$

wurde die Reaktion gestartet. Nach $1 \mathrm{~h}$ Inkubation bei $42^{\circ} \mathrm{C}$ wurde die Reaktion auf Eis beendet. Für die Zweitstrangsynthese wurden

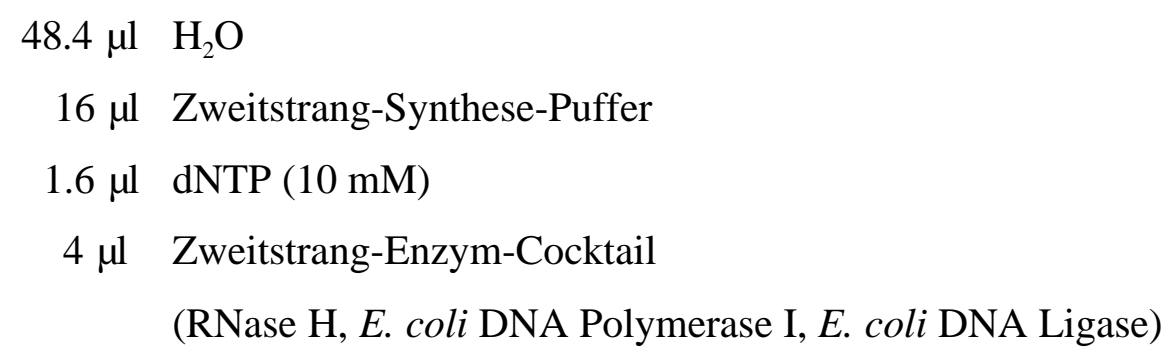

zugegeben und für $2 \mathrm{~h}$ bei $16^{\circ} \mathrm{C}$ inkubiert. Die Enden der doppelsträngigen cDNA wurden dann durch Zugabe von 5 U T4-DNA-Polymerase aufgefüllt, die Reaktion mit Phenol/Chloroform extrahiert und gefällt. Das Pellet wurde in $10 \mu \mathrm{H}_{2} \mathrm{O}$ aufgenommen und hiervon $2 \mu \mathrm{l}$ auf einem Agarosegel getestet. $5 \mu \mathrm{l}$ wurden in einer Ligationsreaktion eingesetzt, in der Linker an die Enden der cDNAs angefügt wurden.

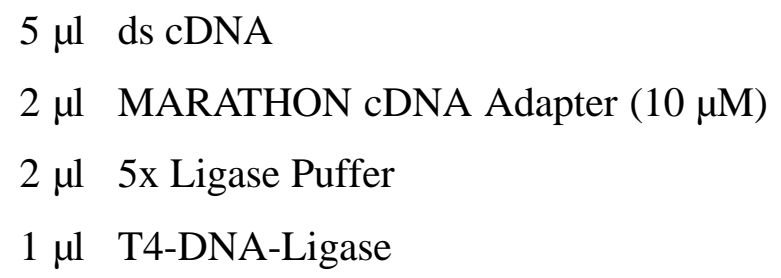

Der Ansatz wurde über Nacht bei $16^{\circ} \mathrm{C}$ inkubiert und dann mit Tris-EDTA Puffer auf eine geeignete Konzentration verdünnt. 


\subsection{Screening der MARATHON cDNA-Banken}

Aliquote von $3 \mu \mathrm{l}$ der verdünnten cDNA Banken wurden in Screening-PCRs mit je einem genspezifischen Primer und dem Linker-Primer AP1 eingesetzt. Die PCRs wurden mit 35 Cyclen durchgeführt:

\begin{tabular}{|l|l|l|}
\hline $94^{\circ} \mathrm{C}$ & $30 \mathrm{sec}$ & Denaturieung \\
\hline $64^{\circ} \mathrm{C}$ & $30 \mathrm{sec}$ & Annealing \\
\hline $68^{\circ} \mathrm{C}$ & $30 \mathrm{sec}$ & Elongation \\
\hline
\end{tabular}

Die Produkte wurden zur Kontrolle direkt sequenziert und dann die 5'- und 3'-Enden der Gene in Fusions-PCRs zusammengesetzt. 10-50 ng dieser Fragmente wurden in eine PCR mit 30 Cyclen eingesetzt:

\begin{tabular}{|l|l|l|}
\hline $94^{\circ} \mathrm{C}$ & $30 \mathrm{sec}$ & Denaturieung \\
\hline $68^{\circ} \mathrm{C}$ & $30 \mathrm{sec}$ & Annealing und Elongation \\
\hline
\end{tabular}

In diese PCRs wurden keine Primer eingesetzt, da die Fragmente über eine Hybridisierung des überlappenden Anteils aneinander binden und als Primer fungieren. Das Produkt dieser PCR wurde 1:100 in $\mathrm{H}_{2} \mathrm{O}$ verdünnt und daraus $1 \mu \mathrm{l}$ in einer PCR mit AP1 und einem Poly-dT Primer eingesetzt. In dieser PCR wurden 38 Cyclen mit folgenden Parametern durchgeführt:

\begin{tabular}{|l|l|l|}
\hline $94^{\circ} \mathrm{C}$ & $30 \mathrm{sec}$ & Denaturieung \\
\hline $52^{\circ} \mathrm{C}$ & $10 \mathrm{sec}$ & Annealing \\
\hline $68^{\circ} \mathrm{C}$ & $30 \mathrm{sec}$ & Elongation \\
\hline
\end{tabular}

Die entstehenden Produkte wurden dann über die in beiden Primern enthaltenen Not I Schnittstellen kloniert. 


\section{Sequenzierungsanalyse}

\subsection{Sequenzierungsreaktion}

Die Sequenzierung wurde modifiziert nach dem Kettenabbruchverfahren von Sanger et al. (1977) durchgeführt. Die Methode beruht auf dem Prinzip der durch den Einbau von Didesoxynukleotiden statistisch unterbrochen DNA-Neusynthese. Doppelsträngige DNA wird denaturiert und ein Einzelstrang nach Anlagerung eines sequenzspezifischen Primers durch eine DNA-Polymerase (Sequenase) aufgefüllt. Die limitierte Zugabe von ddNTPs bewirkt statistische, basenspezifische Synthesestopps (Kettenabbrïche), die im Vergleich die Position der 4 Nukleotide dATP, dCTP, dGTP und dTTP in der Primärsequenz der DNA anzeigen.

\subsection{Sequenzierung-PCR}

Es wurde die 'Dye Terminator Cycle Sequencing' (Perkin-Elmer) Methode angewendet. Dazu wurde das Protokoll des BigDyeTerminator Kits (ABI) befolgt. 0.5-1 $\mu$ g Plasmid-DNA und 5 pmol des jeweiligen Sequenz-Primers wurden auf ein Volumen von $11 \mu \mathrm{mit}$ $\mathrm{H}_{2} \mathrm{O}$ aufgefüllt und mit $4 \mu \mathrm{l}$ Dye-Terminator-Mix versetzt. Dieser Mix enthielt dNTPs, mit vier verschiedenen Fluoreszenzfarbstoffen markierte ddNTPs, Ampli-Taq-DNA-Polymerase sowie Reaktionspuffer. Um eine Evaporation zu verhindern, wurden die Proben mit 1 bis 2 Tropfen Mineralöl überschichtet. Die Kettenabbruchreaktion wurde als PCR in einem Perkin Elmer Thermocycler durchgeführt. Die Amplifikation der Kettenabbruchfragmente durch PCR bietet den Vorteil, daß nur relativ wenig Plasmid-DNA zur Sequenzierung eingesetzt werden muß. Nach Denaturierung bei $95^{\circ} \mathrm{C}$ wurden die Proben für 25 Cyclen folgendem Programm unterzogen: 


\begin{tabular}{|l|l|l|}
\hline $98^{\circ} \mathrm{C}$ & $30 \mathrm{sec}$ & Denaturieung \\
\hline $50^{\circ} \mathrm{C}$ & $15 \mathrm{sec}$ & Annealing \\
\hline $60^{\circ} \mathrm{C}$ & $4 \mathrm{~min}$ & Elongation \\
\hline
\end{tabular}

Nach der PCR wurden die Proben mit $80 \mu \mathrm{H}_{2} \mathrm{O}$ aufgefüllt, unter Mineralöl abgezogen und in ein neues Reaktionsgefäß überführt. $\mathrm{Zu}$ den Ansätzen wurden je $15 \mu \mathrm{l} 3 \mathrm{M} \mathrm{NaAc}(\mathrm{pH}$ 4.5) und $300 \mu \mathrm{l}$ kalter, absoluter Ethanol pipettiert und die DNA 15 min mit 10000x g bei $4^{\circ} \mathrm{C}$ pelletiert. Das Pellet wurde mit $70 \%$ Ethanol gewaschen, für $5 \mathrm{~min}$ bei $2500 \mathrm{x} \mathrm{g}$ zentrifugiert, luftgetrocknet, in $5 \mu$ Formamid-Mix (50 mM EDTA pH 8.0; mit Formamid im Verhältnis 5:1) aufgenommen und auf ein 6.8\%iges Sequenzgel aufgetragen.

\subsection{PAGE-Gel für die automatische Sequenzierung}

Die Auswertung der fluoreszenzmarkierten Sequenzierung erfolgte mit einem automatischen Sequenzier Modell 373A (Applied Biosystem). Bei diesem Gerät regt ein Laser die Fluoreszenzfarbstoffe zur Lichtemission an, welche dann in einem 'photomultiplier' verstärkt und in einem Detektor registriert wird. Die Auswertung erfolgt durch einen Computer. Zunächst wurden für das Sequenzgel zwei Glasplatten gesäubert, zusammengebaut und die Sequenzgellösung mit einer Wasserstrahlpumpe entgast. Die Lösung wurde nach Zugabe von TEMED und APS luftblasenfrei zwischen die Glasplatten gegossen. Nach der Polymerisation des Gels für 2 h wurde der Vorlauf ( 1 h bei 1400 V) gestartet. Die Sequenzproben wurden vor dem Auftragen für $7 \mathrm{~min}$ bei $95^{\circ} \mathrm{C}$ denaturiert und auf Eis abgekühlt. Die eigentliche Elektrophorese erfolgte in 1x TBE-Puffer (Roth, Karlsruhe) bei $1400 \mathrm{~V}$ für $14 \mathrm{~h}$. 


\section{Primer Extension Analyse}

(modifiziert nach Domenjoud et al., 1990)

Diese Methode dient der Ermittlung des Transkriptionspunktes eines Gens. Das Prinzip der Methode beruht auf Anlagerung eines radioaktiv oder fluoreszenz markierten Primers an die mRNA und Synthese eines zweiten komplementären Stranges mit Hilfe des Enzyms, Reverse Transkriptase.

Der fluoreszenzmarkierte Primer (10 pmol) wurde mit $20 \mu \mathrm{g}$ Maustestis-Gesamt-RNA auf $11 \mu \mathrm{l}$ DEPC- $\mathrm{H}_{2} \mathrm{O}$ gemischt und für 10 min bei $70^{\circ} \mathrm{C}$ inkibiert. Nach dem Abkühlen auf Eis wurden die folgenden Komponenten zu dem Ansatz zugegeben:

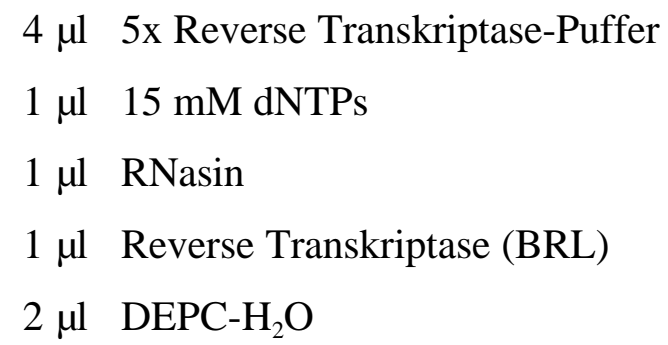

Der Gesamtansatz im Volumen von $20 \mu \mathrm{l}$ wurde für $1 \mathrm{~h}$ bei $42^{\circ} \mathrm{C}$ inkubiert. Die cDNA wurde über einer Ethanolfällung pelletiert, mit $70 \%$ Ethanol gewaschen, luftgetrocknet, in $5 \mu \mathrm{l}$ Formamid-Mix (50 mM EDTA, pH 8.0; mit Formamid im Verhältnis 5:1) aufgenommen und auf ein 6.8\%iges Sequenzgel für die automatische Sequenzierung aufgetragen. 


\section{Verdauung der Poly $(A)^{+}$- Schwanz von Gesamt-RNA}

(Kleene et al., 1984)

Durch die Hybridisierung synthetischer Oligonukleotide (Poly $(\mathrm{dT})_{12-18}$ ) an den Poly $(\mathrm{A})^{+}-$ Schwanz von mRNAs und anschließender Verdauung dieses künstlich hergestellten doppelsträngigen DNA/RNA-Hybrids durch RibonukleaseH (doppelstrangspezifisch) können unterschiedlich lange Poly $(\mathrm{A})^{+}-$Schwänze identifiziert werden.

Dazu wurden drei getrennte Ansätze von $20 \mu \mathrm{g}$ Maustestis Gesamt-RNA mit $2 \mu \mathrm{g}$ Oligo $(\mathrm{dT})_{12-18}$ versetzt und für $3 \mathrm{~min}$ bei $65^{\circ} \mathrm{C}$ inkubiert. Anschließend wurden den Reaktionsansätzen 0.2 Vol. 5x Ribonukleasepuffer H zugegeben und für 15 min auf Eis gestellt. Die Proben wurden durch Zugabe von $1 \mu \mathrm{l}$ RibonukleaseH (BRL, $12 \mathrm{U} / \mu \mathrm{l})$ bei $37^{\circ} \mathrm{C}$ verdaut (Reaktionszeit von 0-, 15- und $30 \mathrm{~min}$ ) und danach sofort einer Phenol/ChloroformExtraktion unterworfen. Die Überstände wurden mit 0.1 Vol. $3 \mathrm{M} \mathrm{NaAc}(\mathrm{pH} 4.8)$ und 2.5 Vol. Ethanol für $20 \mathrm{~min}$ bei $-70^{\circ} \mathrm{C}$ präzipitiert und die verdauten RNA-Moleküle durch Zentrifugation (13000x g, 15 min, $4^{\circ} \mathrm{C}$ ) sedimentiert. Danach wurden die Reaktionsansätzen mit 70\%igem Ethanol gewaschen, wie unter II.11.3. beschrieben behandelt und gelelektrophoretisch aufgetrennt.

\section{Herstellung von Paraffinschnitten aus Geweben, Organen und Embryonen}

Das frisch präparierte Material wurde direkt in das entsprechende Fixativ gegeben und je nach Größe des Präparats für eine Stunde bis zu einer Woche bei RT fixiert.

Bouin'sches Gemisch:

Fixiergemisch mit Glutaraldehyd:
15 Teile gesättigte Pikrisäure (filtriert)

5 Teile 37\%ige Formaldehylösung

1 Teil Eisessig

$50 \mathrm{mM} \quad$ Na-Phosphatpuffer ( $\mathrm{pH} 7.4)$

$5.5 \%$ Glutaraldehyd 


\section{$3 \% \quad \mathrm{NaCl}$}

Fixiergemisch mit Paraformaldehyd:

4\% Paraformaldehyd

$10 \mathrm{ml}$ 10x PBS

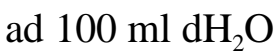

Mit Hilfe einer aufsteigenden Alkoholreihe (50\%, 70\%, 90\% und 96\%) wurde das Gewebe entwässert. Um den Ethanol vor der Einbettung in das Paraffin vollständig zu entfernen, wurde das Gewebe über Nacht in Methylbenzoat inkubiert.

Für die Einbettung wurde das Paraffin im Wasserbad bei $58^{\circ} \mathrm{C}$ geschmolzen. Die Einbettung bestand aus mehreren Schritten, die sämtlich bei $58^{\circ} \mathrm{C}$ durchgeführt wurden. Für die Entfernung des Methylbenzoats wurde das Gewebe zweimal mit Benzol und zweimal in einem 1:1 Benzol/ Paraffin-Gemisch jeweils für $1 \mathrm{~h}$ inkubiert. Zur vollständigen Durchdringung des Gewebes mit dem Paraffin wurde das Präparat anschließend zweimal für $1 \mathrm{~h}$ in Paraffin inkubiert. Im Anschluß daran wurde die auf $58^{\circ} \mathrm{C}$ temperierte Einbettungsform etwa zur Hälfte mit geschmolzenem Paraffin gefüllt, das Gewebe in die Form überführt und mit Paraffin aufgefüllt. Nach der Aushärtung über Nacht wurde der Paraffinblock aus der Form genommen und bei $4^{\circ} \mathrm{C}$ gelagert.

Die Paraffinblöcke mit dem fixierten Material wurden zu Quadern optimaler Größe zurechtgeschnitten und in das Mikrotom (Hn 40 Ing., Nussloch) eingespannt. Die Schnittdicke betrug 5-8 $\mu \mathrm{m}$. Mit Hilfe eines feinen Pinsels wurden die Schnitte auf die vorbehandelten Objektträger übertragen. Um eine bessere Haftung der Schnitte zu erreichen, wurden die Objektträger mit einem Tropfen 70\%igem Ethanol benetzt und diese auf einer $40^{\circ} \mathrm{C}$ warmen Heizplatte erwärmt. Die Schnitte wurden direkt auf den Ethanoltropfen aufgelegt und solange auf der Wärmeplatte belassen, bis das Ethanol vollständig verdampft war. Bis zur weiteren Verwendung wurden die Schnitte lichtgeschützt bei $4^{\circ} \mathrm{C}$ gelagert. 


\section{3. ' whole mount'-in situ-Hybridisierung}

(modifiziert nach Wilkinson und Nieto, 1993)

Die Methode der 'whole mount'- in situ-Hybridisierung ermöglicht einen dreidimensionalen und zellgenauen Nachweis der Expression von Genen in der frühen Embryogenese. Die 'whole mount'- in situ-Hybridisierung ist besonders geeignet für Embryonalstadien 7 - 13 Tage post coitum (pc) bzw. aus dem Embryonen isolierten Gewebe.

\subsection{Präparation der Maus-Embryonen}

Weibliche NMRI Mäuse wurden verpaart und am nächsten Morgen auf einen Varginalpfropf als äußeres Zeichen für die Kopulation kontrolliert. Embryonen (pc) wurden an den gewünschten Tagen präpariert und in 4\% Paraformaldehyd in PBS $2 \mathrm{~h}$ bis über Nacht inkubiert. Danach folgten zweimal Waschschritte in PBT (0.1\% Tween-20 in PBS) bei $4^{\circ} \mathrm{C}$ für 5 min. Die Embryonen wurden über eine aufsteigende Methanolreihe in PBT (25\%, $50 \%$ und $75 \%$, je 5 min) entwässert. Nach zweimaliger Inkubation in 100\% Methanol für je 5 min konnte das Gewebe bis zur weiteren Verwendung bei $-20^{\circ} \mathrm{C}$ gelagert werden.

\subsection{Vorbehandlung der Embryonen}

Die Behandlung der Embryonen vor der Hybridisierung mit DIG-markierten RNA-Sonden erfolgte nach folgender Prozedur:

\begin{tabular}{|l|l|}
\hline Rehydrieren (in einer absteigenden Methanolreihe in PBT) & $75 \%, 50 \%$ und 25\%, je 5 min \\
\hline $2 \mathrm{x}$ PBT & $5 \mathrm{~min}$ \\
\hline $6 \% \mathrm{H}_{2} \mathrm{O}_{2}$ in PBT (frisch) & $1 \mathrm{~h}$ \\
\hline $3 \mathrm{x}$ PBT & $5 \mathrm{~min}$ \\
\hline $10 \mu \mathrm{g} / \mathrm{ml}$ Proteinase $\mathrm{K}$ in PBT (frisch) & $3-15 \mathrm{~min}$ \\
\hline
\end{tabular}




\begin{tabular}{|l|l|}
\hline $2 \mathrm{mg} / \mathrm{ml}$ Glycin in PBT (frisch) & $5 \mathrm{~min}$ \\
\hline $2 \mathrm{x}$ PBT & $5 \mathrm{~min}$ \\
\hline $0.2 \%$ Glutaraldehyd/ 4\% Prarformaldehyd in PBT (frisch) & $20 \mathrm{~min}$ \\
\hline $2 \mathrm{x}$ PBT & $5 \mathrm{~min}$ \\
\hline
\end{tabular}

\subsection{Synthese von RNA-Proben: DIG-Markierung}

Die in vitro Transkripte wurden nach der Anleitung des DIG-RNA Labeling Kits (Boehringer, Mannheim) markiert. Folgende Reagenzien wurden zusammenpipettiert:

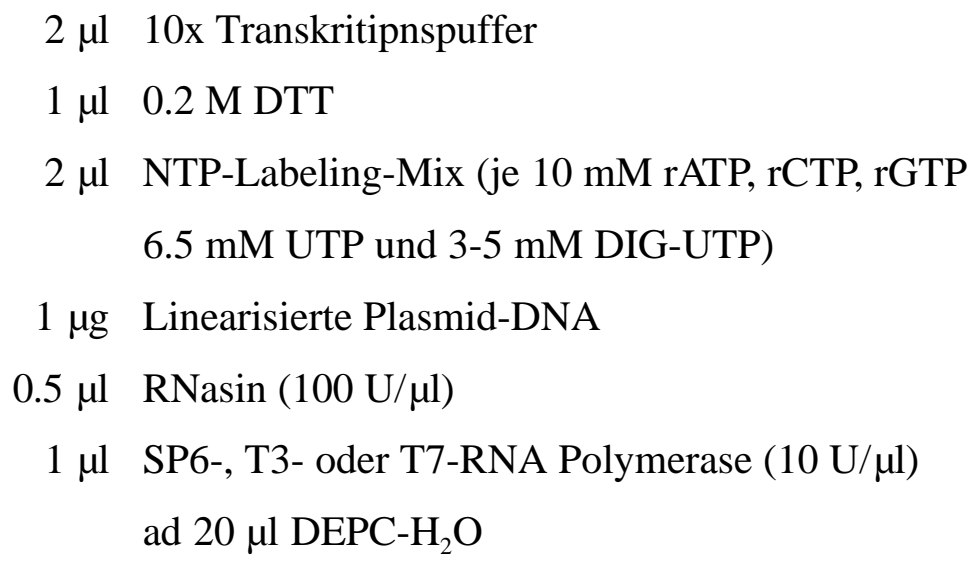

Für die Durchführung der Markierungsreaktion wurde dieser Ansatz für $2 \mathrm{~h}$ bei $37^{\circ} \mathrm{C}$ inkubiert. Die Reaktion wurde durch Zugabe von $2 \mu 10.2$ M EDTA (pH 8.0) abgestoppt. Die markierte RNA wurde mit Hilfe von $2.4 \mu \mathrm{l} 4 \mathrm{M} \mathrm{LiCl}$ und $75 \mu \mathrm{l} 100 \%$ Ethanol 30 min bei $-70^{\circ} \mathrm{C}$ gefällt, mit $70 \%$ Ethanol gewaschen und bei $37^{\circ} \mathrm{C}$ getrocknet. Das Pellet wurde in 100 $\mu \mathrm{l}$ DEPC- $\mathrm{H}_{2} \mathrm{O}$ gelöst. Die Effizienz der Markierung und die Menge der synthetisierten RNA wurden mit Hilfe eines immunologischen Nachweises des eingebauten Digoxygenins überprüft. Dazu wurde aus der markierten RNA-Probe und aus markierter Kontroll-RNA bekannter Konzentration eine Verdünnungsreihe hergestellt, die auf eine Nylonmembran aufgetropft und luftgetrocknet wurde. Unter Verwendung des 'DIG-Nucleic Acid Detection'Kits (Boehringer, Mannheim) wurden eingebauten DIG-Nukleotide mit Hilfe eines spezifischen Antikörpers nachgewiesen. Mit Hilfe der aufgetragenen markierten KontrollRNA ließ sich die Kozentration der markierten Probe abschätzen. 


\subsection{Hybridisierung mit DIG-markierten RNA-Sonden}

Es wurde $1 \mathrm{ml}$ Hybridisierungslösung zugeben und mindestens $1 \mathrm{~h}$ bei $70^{\circ} \mathrm{C}$ präinkubiert. Die Hybridisierung wurde über Nacht bei $70^{\circ} \mathrm{C}$ im Wasserbad unter Schütteln durchgeführt. $\mathrm{Zu}$ diesem Zeitpunkt wurde die Embryonen entweder in die 50\% Formamid/ 5x SSC (pH 4.5) überführt und zur weiteren Verwendung bei $-20^{\circ} \mathrm{C}$ gelagert oder anschließend mit der DIGmarkierten RNA-Probe $(0.5 \mu \mathrm{g} / \mathrm{ml})$ hybridisiert.

$\begin{array}{rll}\text { Hybridisierungslösung: } \quad 50 \% & \text { Formamid } \\ 5 \mathrm{x} & \text { SSC }(\mathrm{pH} 4.5) \\ 50 \mu \mathrm{g} / \mathrm{ml} & \text { Hefe-tRNA } \\ 1 \% & \text { SDS } \\ 50 \mu \mathrm{g} / \mathrm{ml} & \text { Heparin }\end{array}$

\subsection{Waschen nach der Hybridisierung}

Zum Waschen der Embryonen wurden folgene Schritte durchgeführt:

\begin{tabular}{|l|l|}
\hline 2 x Lösung 1 & $30 \mathrm{~min}, 70^{\circ} \mathrm{C}$ \\
\hline 1x 1:1 (Lösung 1: Lösung 2) & $10 \mathrm{~min}, 70^{\circ} \mathrm{C}$ \\
\hline 3 x Lösung 2 & $5 \mathrm{~min}, \mathrm{RT}$ \\
\hline $100 \mu \mathrm{g} / \mathrm{ml}$ RNase in Lösung 2 & $15-30 \mathrm{~min}, \mathrm{RT}$ \\
\hline 1x Lösung 2 & $5 \mathrm{~min}, \mathrm{RT}$ \\
\hline 1x Lösung 3 & $5 \mathrm{~min}, \mathrm{RT}$ \\
\hline 2x Lösung 3 & $30 \mathrm{~min}, 65^{\circ} \mathrm{C}$ \\
\hline $3 x$ TBST & $5 \mathrm{~min}, \mathrm{RT}$ \\
\hline 1x 10\% FKS in TBST & $5 \mathrm{~min}$ \\
\hline 1x 10\% FKS in TBST & $60-90 \mathrm{~min}$ \\
\hline
\end{tabular}


Lösung 1:

Lösung 2:

Lösung 3:
$50 \%$ Formamid

$5 \mathrm{x} \quad \mathrm{SSC}(\mathrm{pH} 4.5)$

$0.1 \%$ Tween-20

$50 \%$ Formamid

$2 \mathrm{x} \quad \mathrm{SSC}(\mathrm{pH} 4.5)$

\subsection{Detektion der Hybridisierungssignale}

Zur Detektion der hybridisierten RNA-Sonden wurden der Anti-DIG-AP ('alkaline phosphatase') gekoppelte Antikörper (AK) der Firma Boehringer verwendet. Zur Behandlung des Anti-DIG-AP-Antikörpers wurden $3 \mathrm{mg}$ Embryonenpulver in $0.5 \mathrm{ml}$ TBST gegeben, 30 min bei $70^{\circ} \mathrm{C}$ inkubiert und dann auf Eis abgekühlt. Danach wurden $5 \mu \mathrm{FKS}$ und $1 \mu \mathrm{l}$ AntiDIG-AP-Antikörper zugegeben und $1 \mathrm{~h}$ bei $4^{\circ} \mathrm{C}$ unter Schütteln inkubiert. Nach Abzentrifugieren wurde die Embryonen weiter über Nacht bei $4^{\circ} \mathrm{C}$ unter Schütteln in $1 \mathrm{ml}$ Überstand mit $3 \mathrm{ml}$ 1\% FKS/TBST inkubiert. Zum Waschen der Embryonen am nächsten Tag wurden folgende Schritte durchgeführt:

\begin{tabular}{|l|l|}
\hline $3 x$ TBST & $5 \mathrm{~min}, \mathrm{RT}$ \\
\hline $5 \mathrm{x}$ TBST & $1 \mathrm{~h}, \mathrm{RT}$ \\
\hline $3 \mathrm{x}$ NTMT & $10 \mathrm{~min}, \mathrm{RT}$ \\
\hline
\end{tabular}

Der Nachweis des Antikörpers erfolgte durch eine Farbreaktion. Dazu wurden die Embryonen in $4.5 \mu \mathrm{l}$ NBT und $3.5 \mu \mathrm{l}$ BCIP in $1 \mathrm{ml}$ NTMT $30 \mathrm{~min}$ bis mehrere Stunden im Dunkeln inkubiert. Zum Abstoppen der Farbreaktion wurden die Embryonen in PBT gewaschen. Die Auswertung erfolgte durch Fotografie unter einem Lichtmikroskop (Zeiss). 


$\begin{array}{lrl}\text { TBST: } & 150 \mathrm{mM} & \mathrm{NaCl} \\ 100 \mathrm{mM} & \mathrm{KCl} \\ 250 \mathrm{mM} & \text { Tris/HCl }(\mathrm{pH} 7.5) \\ 1 \% & \text { Tween-20 } \\ 2 \mathrm{mM} & \text { Levamisole } \\ & & \\ \text { NTMT: } & 100 \mathrm{mM} & \mathrm{NaCl} \\ & 100 \mathrm{mM} & \text { Tris/HCl (pH 9.5) } \\ 50 \mathrm{mM} & \mathrm{MgCl}_{2} \\ 0.1 \% & \text { Tween-20 }^{2} \\ 2 \mathrm{mM} & \text { Levamisole }\end{array}$

\section{Proteinchemische Techniken}

\subsection{Isolierung von Gesamtprotein aus Gewebe}

Frisches Gewebe wurde in ein 15 bzw. 50 ml Falcon-Gefäß mit 1 Vol. SEM-Puffer gegeben. Das Gewebe wurde mit einem Dispergierwerkzeug (Ultraturrax T25, Schütt, Göttingen) homogenisiert, und die groben Gewebetrümmer wurden abzentrifugiert (4000 rpm, 10 min, $4^{\circ} \mathrm{C}$ ). Der Proteinüberstand wurde nach Zugabe von 1 Vol. 2x SDS-Auftragspuffer zur Denaturierung $10 \mathrm{~min}$ im Wasserbad gekocht und danach auf Eis abgekühlt. $10 \mu \mathrm{l}$ des Überstandes mit SDS-Auftragspuffer wurden im SDS-Gel aufgetrennt. Die Lagerung der Proben erfolgt bei $-80^{\circ} \mathrm{C}$.

\subsection{SDS-Polyacrylamidgel}

Zur Auftrennung von Proteingemischen wurden Gele mit 6\%-20\% Acrylamidgehalt 
verwendet. Je nach Anwendung wurden auch Gele mit einem Gradienten der Acrylamidkonzentration benuzt. Bei der SDS-PAGE erfolgt die Auftrennung der Proteine im wesentlichen aufgrund unterschiedlicher Molekulargewichte.

Zur Herstellung der SDS-PAA-Gele wurden die in der folgenden Tabelle aufgeführten Lösungen für das Trenngel zusammenpipettiert, kurz gemischt, entgast und zwischen die gesäuberten Glasplatten gefüllt. Das Trenngel wurde mit wenig Buthanol überschichtet und mindestens $1 \mathrm{~h}$ polymerisiert. Anschließend wurde das Buthanol abgeschüttelt. Die Lösungen für das Sammelgel wurden zusammenpipettiert, entgast und auf das Trenngel geschichtet. Der Gelkamm wurde luftblasenfrei eingesetzt. Nachdem das Sammelgel polymerisiert ist, wurden die Gele an die Elektrophoresekammaer angeklammert und mit Elektrophoresepuffer überschichtet. Die Elektrophorese der Proben erfolgt mit 10-15 mA über Nacht.

\section{Herstellung der Gelösungen:}

\begin{tabular}{|l|l|l|l|l|}
\hline \multicolumn{5}{|c|}{ Trenngel (30 ml) } \\
\hline Acrylamidkonzentration & $6 \%$ & $10 \%$ & $12 \%$ & $15 \%$ \\
\hline $\mathrm{H}_{2} \mathrm{O}$ & $13.9 \mathrm{ml}$ & $11.9 \mathrm{ml}$ & $9.9 \mathrm{ml}$ & $6.9 \mathrm{ml}$ \\
\hline Acrylamidlösung $(30 \%)$ & $8.0 \mathrm{ml}$ & $10.0 \mathrm{ml}$ & $12.0 \mathrm{ml}$ & $15.0 \mathrm{ml}$ \\
\hline Lower-Tris (4x) & $7.5 \mathrm{ml}$ & $7.5 \mathrm{ml}$ & $7.5 \mathrm{ml}$ & $7.5 \mathrm{ml}$ \\
\hline $10 \%$ APS & $0.3 \mathrm{ml}$ & $0.3 \mathrm{ml}$ & $0.3 \mathrm{ml}$ & $0.3 \mathrm{ml}$ \\
\hline TEMED & $18 \mu \mathrm{l}$ & $12 \mu \mathrm{l}$ & $12 \mu \mathrm{l}$ & $12 \mu \mathrm{l}$ \\
\hline
\end{tabular}

\begin{tabular}{|l|l|}
\hline \multicolumn{2}{|c|}{ Sammelgel (10 ml) } \\
\hline $\mathrm{H}_{2} \mathrm{O}$ & $6.8 \mathrm{ml}$ \\
\hline Acrylamidlösung (30\%) & $1.7 \mathrm{ml}$ \\
\hline Upper-Tris (4x) & $1.25 \mathrm{ml}$ \\
\hline $10 \%$ APS & $0.1 \mathrm{ml}$ \\
\hline TEMED & $10 \mu \mathrm{l}$ \\
\hline
\end{tabular}

\section{3 'Semi dry blot'}

Proteine werden standardmäßig nach einer gelelektrophoretischen Auftrennung auf eine PVDF-Membran transferiert. Hierzu wurden 18 Filterpapiere sowie ein PVDF-Filter in der 
Größe des Trenngels zurechtgeschnitten. Für den 'semi dry blot' wurden die Graphitplatten der Transferapparatur mit $\mathrm{dH}_{2} \mathrm{O}$ abgerieben. 6 Filterpapiere wurden in $0.3 \mathrm{M}$ Tris/ $\mathrm{HCl}, \mathrm{pH}$ 10.4/ 20\% Methanol getränkt und luftblasenfrei auf die Anodenplatte aufgelegt. Darauf wurden 3 Filterpapiere, die in $25 \mathrm{mM}$ Tris/ $\mathrm{HCl}$, pH 10.4/ 20\% Methanol getränkt wurden, geschichtet. Die Immobilon-P'-Membran wurde in Methanol angefeuchtet, kurz in $25 \mathrm{mM}$ Tris/HCl, pH 10.4/ 20\% Methanol gewaschen und auf die Filterpapiere gelegt. Das Gel wurde von den Glasplatten gelöst, das Sammelgel wurde abgetrennt und verworfen, während das Trenngel vorsichtig auf die Membran aufgebraucht wurde. Anschließend wurden 9 Filterpapiere, die in $40 \mathrm{mM} \varepsilon$-Aminocapronsäure/ $25 \mathrm{mM}$ Tris/ $\mathrm{HCl}, \mathrm{pH}$ 9.4/ 20\% Methanol getränkt wurden, auf das Gel geschichtet. Nachdem die Kathodenplatte aufgebracht worden ist, erfolgt der Transfer für $1 \mathrm{~h}$ bei $0.8 \mathrm{~mA} / \mathrm{cm}^{2}$. Nach dem Transfer wurde die Membran entweder gefärbt oder mit einem monospezifischen Antikörper bzw. polyklonalen Antiserum umgesetzt.

\subsection{Färbung von Polyacrylamidgelen}

SDS-Gele wurden standardmäßig mit Coomassie Brilliant Blue R250 gefärbt. Nach der Elektrophorese wurde das Gel ca $30 \mathrm{~min}$ in der Färbelösung geschwenkt. zur Differenzierung wurde das Gel anschließend für mehrere Stunden in Entfärberlösung bewegt, wobei der Entfärber mehrmals gewechselt wurde.

$\begin{array}{lll}\text { Färbelösung: } & 45 \% & \text { Methanol } \\ 9 \% & \text { Essigsäure } \\ & 0.05 \% & \text { Coomassie Brilliant Blue R250 } \\ & & \\ \text { Entfärberlösung: } & 5 \% & \text { Methanol } \\ & 7.5 \% & \text { Essigsäure }\end{array}$

\subsection{Reversible Färbung von 'Western blots'}

(Pryor et al., 1992) 
Proteine, die nach Elektrotransfer an Membranen gebunden sind, können reversibel mit Coomassie Brilliant Blue R250 (CBB-R250) gefärbt werden. Zur Färbung wurde der Filter 5 min in $0.1 \%$ CBB-R250 in 50\% Methanol geschwenkt. Der Filter wurde in einem Gemisch aus 1:2:1 $\mathrm{dH}_{2} \mathrm{O}$ :Methanol:Essigsäure differenziert bzw. entfärbt. Nach vollständiger Entfärbung kann der Filter für eine Immunumsetzung verwendet werden.

\subsection{Immunumsetzung von Proteinfiltern}

Unspezifische Bindungsstellen auf der Membran wurden vor der Umsetzung mit dem Antiserum $1 \mathrm{~h}$ mit Blockpuffer abgesättigt. Danach wurde der Proteinfilter in einer Plastiktüte mit $1 \mathrm{ml} / 10 \mathrm{~cm}^{2}$ Antiserum (1:500 in Waschpuffer verdünnt) entweder $1 \mathrm{~h}$ bei RT oder über Nacht bei $4^{\circ} \mathrm{C}$ inkubiert. Ungebundene Antikörper wurden $1 \mathrm{~h}$ in Waschpuffer (3-4 Wechsel) entfernt. Der mit alkalischer Phosphatase gekoppelte Zweitantikörper wurde 1:5000 in Waschpuffer verdünnt. Die Membran wird für $1 \mathrm{~h}$ in Antikörperlösung geschwenkt, danach wurden wiederum 3-4x für jeweils 15 min die nicht gebundenen Antikörper in Waschpuffer entfernt. Der Filter wurde anschließend $2 \mathrm{~min}$ in Puffer 3 umgepuffert, bevor er mit $1 \mathrm{ml} / 10 \mathrm{~cm}^{2}$ Färbelösung in einer Plastiktüte eingeschweißt wurde. Die Farbentwicklung erfolgt in der Dunkelheit. Nach der Farbreaktion wurde der Filter in $\mathrm{dH}_{2} \mathrm{O}$ kurz gewaschen und anschließend auf einem Filterpapier getrocknet.

\subsection{Immunlokalisierung von Proteinen in Paraffinschnitten}

Deparaffinierte Schnitte wurden 5 min in PBS/ 1\% Triton X-100 permeabilisiert. Nachdem die Präparate 2x 5 min in PBS gewaschen worden waren, wurde um die Schnitte herum die überschüssige Flüssigkeit abgesaugt. Unspezifische Bindungsstellen wurden 30 min mit 50$100 \mu \mathrm{l} 5 \%$ Ziegen-Normalserum in PBT abgesättigt. Danach wurde erneut überschüssige Flüssigkeit mit einem Filterpapier abgesaugt. Auf das Präparat wurden $10 \mu \mathrm{l}$ der 
monospezifischen Antikörperlösung gegeben und mit einem Deckglas luftblasenfrei bedeckt. Die Schnitte wurden $2 \mathrm{~h}$ in einer feuchten Kammer mit PBS als Puffer inkubiert. Unspezifisch bindende Antikörper wurden in PBT 4x 10 min abgewaschen. Der Zweitantikörper (Ziege- $\alpha$-Kaninchen-alkalische Phosphatase) wurde 1:500 in PBT verdünnt. Pro Objektträger wurden 50-100 $\mu \mathrm{l}$ Antikörperlösung eingesetzt. Nach $2 \mathrm{~h}$ Inkubation in einer feuchten Kammer wurden nicht gebundene Antikörper 4x 10 min in PBT ausgewaschen. Das Gewebe wurde in Puffer 32 min umgepuffert, bevor $50 \mu$ Färbelösung auf den Schnitt gegeben wurden. Die Farbreaktion erfolgte unter einem Deckglas und wurde regelmäßig unter dem Mikroskop kontrolliert. Durch Eintauchen der Objektträger in TE-Puffer wurde die Reaktion gestoppt. Danach wurden die Präparat in $\mathrm{dH}_{2} \mathrm{O}$ kurz gewaschen und mit einem Tropfen 'Aqua-Polymount' eingedeckelt.

\section{Herstellung des polyklonalen Antikörpers gegen das HASH-Peptid}

\subsection{Kopplung des synthetischen Peptids an BSA}

$20 \mathrm{mg}$ BSA (ca. $0.3 \mu \mathrm{Mol}$ ) wurden in $0.5 \mathrm{ml} 0.4 \mathrm{M}$ Phosphatpuffer, pH 7.5 gelöst. $10 \mu \mathrm{Mol}$ des synthetisierten Peptids wurden in $1.5 \mathrm{ml}$ PBS gelöst. BSA- und Peptid-Lösung wurden gemischt und unter ständigem Rühren zu $1 \mathrm{ml}$ einer wässerigen Glutaraldehydlösung (2-15 $\mu \mathrm{M}$ Endkonzentration) in einem Zeitraum von $5 \mathrm{~min}$ tropfenweise zugegeben. Das Gemisch wurde für weitere 30 min gerührt. Nicht umgesetztes Glutaraldehyd wurde durch Zugabe von 0.1 Vol. $1 \mathrm{M}$ Glycinlösung inaktiviert. Dazu wurde das Gemisch für weitere $30 \mathrm{~min}$ gerührt und anschließend gegen PBS über Nacht dialysiert.

\subsection{Gewinnung eines polyklonalen Antiserums}

Für proteinchemische Untersuchungen wurde ein polyklonales Antiserum gegen das HASHOligopeptid in Neuseeland Kaninchen erzeugt. Zur Präimmunisierung wurde ein 1:1 
Gemisch aus dem synthetischen Peptid, das zur Steigerung der Immunogenität an BSA gekoppelt worden war, und „Freund'sches Complete Adjuvans “ subkutan verabreicht. Nach 3 Wochen erfolgte eine 'Boost'-Immunisierung mit einem Gemisch 1:1 aus dem gekoppelten Peptid und „Freund’schem Incomplete Adjuvans “. 14 Tage nach der 2. Immunisierung wurde dem Kaninchen durch Herzpunktion das Blut entnommen. Zur Gerinnung der zellulären Bestandteile wurde das Blut für eine Stunde bei $37^{\circ} \mathrm{C}$ und danach über Nacht bei $4^{\circ} \mathrm{C}$ inkubiert. Die agglutinierten Bestandteile wurden durch Zentrifugation (15 min, 10000x g) pelletiert. Das aliquotierte Serum wurde bei $-80^{\circ} \mathrm{C}$ gelagert.

\subsection{Aufreinigung monospezifischer Antikörper}

Für eine genauere Analyse müssen die im polyklonalen Antiserum enthaltenen Antikörper gegen das gewünschte Protein von den übrigen Antikörpern getrennt werden. Hierzu wurde der Kopplungkomplex (Peptid-BSA) im PAA-Gel aufgetrennt und auf eine Immobilon PMembran transferiert. Nach dem Transfer wurde die Bande ausgeschnitten, mit $200 \mu \mathrm{l}$ des polyklonalen Antiserums $1 \mathrm{~h}$ umgesetzt und dann 3x $10 \mathrm{~min}$ in Waschpuffer bewegt. Zur Elution der monospezifischen Antikörper von der Membran wurde der Filterstreifen 15 min mit $1 \mathrm{ml}$ Elutionslösung heftig geschüttelt. Nachdem der Filterstreifen erneut in PBS gewaschen worden war, konnte er wieder mit dem polyklonalen Antiserum umgesetzt werden. Die eluierten Antikörper wurden in ein Centrisart-Röhrchen (Satorius, Göttingen) überführt und durch Zentrifugieren bei 2500x g konzentriert. Der Überstand wurde verworfen, die Restflüssigkeit mit PBS auf das Ausgangsvolumen aufgefüllt und erneut zentrifugiert. Dieser Vorgang wurde solange wiederholt, bis das KSCN vollständig aus der Antikörperlösung entfernt worden war (3-4 mal). Die monospezifische Antikörperlösung wurde mit $0.2 \% \mathrm{NaN}_{3}$ versetzt und bei $4^{\circ} \mathrm{C}$ gelagert.

\section{Elutionslösung: $\quad 3 \mathrm{M}$ KSCN \\ $0.1 \%$ BSA}

in 1x PBS 


\section{Techniken zur Herstellung von 'Knock out'-Mäusen}

\subsection{Routinekultur von ES-zellen}

Die Isolation und gezielte Manipulation von pluripotenten embryonalen Stammzellen (ESZellen) ist ein entscheidender Fortschritt im Rahmen der entwicklungsbiologischen Forschung bei Säugertieren. Die ersten ES-Zellen wurden von Evans und Kaufmann (1981) und Martin (1981) aus der inneren Zellmasse von Blastocysten des 129/SvMausstammes isoliert. Bald danach wurde von Bradley et al. (1984) gezeigt, daß diese Zellen sich an der Entwicklung sämtlicher Gewebe des resultierenden Embryos, einschließlich der Keimdrüsen beteiligen, wenn sie in die Blastocysten injiziert werden. Die erste genetische Manipulation an ES-Zellen wurde von Robertson et al. (1986) und Gossler et al. (1986) durchgeführt. Diese Gruppen konnten zeigen, daß Mutationen im Genom von ES-Zellen von diesen durch die Keimbahn transmittiert werden. Die ersten erfolgreichen homologen Rekombinationen in ES-Zellen wurden fast gleichzeitig von Thomas und Capecchi (1987) sowie Doetschmann et al. (1987) publiziert.

In der vorliegenden Arbeit wurden 'Knock out'-Mäuse über die Aggregation von ES-Zellen mit 2.5 Tage alten Mausembryonen bzw. über die Blastocysteninjektion generiert. Für diesen Zweck wurden RI-ES-Zellen verwendet. RI-ES-Zellen der Passage 12 wurden zusammen mit Mitomycin C behandelten embryonalen Feederzellen (EmFi) auf $0.2 \%$ Gelatinebeschichteten Kulturschalen ausgesät. Das Kulturmedium wurde aufgrund der starken Ansäuerung durch die ES-Zellen täglich gewechselt. Eine erneute Passagierung wurde je nach Dichte der Zellen alle 2-3 Tage durchgeführt. Bei regulären Passagen wurden ESZellen in Trypsin/ EDTA-Puffer 1:3 bis 1:8 geteilt. Vor der erneuten Plattierung wurde die Trypsinlösung durch Zentrifugation mit 270x g für 5 min bei RT entfernt. Bei jeder Passage wurden Stocks der ES-Zellen in flüssigem Stickstoff kryokonserviert. 


\subsection{Elektroporation und Selektion von ES-Zellen}

Die Elektroporation ist eine physikalische Methode zum Gentransfer. Sie basiert auf der Erkenntnis, daß biologische Membranen durch die Einwirkung kurzer elektrischer Impulse oberhalb der kritischen Feldstärke vorübergehend permeabilisiert werden, ohne daß die Membranstruktur zerstört wird. Während der Phase erhöhter Durchlässigkeit kann ein Stofftransport durch die Membran erfolgen. Die Elektroporation der ES-Zellen wurde nach den Angaben von Joyner (1993) durchgeführt. Dazu wurden 7 x $10^{6}$ bis $2 \times 10^{7}$ exponentiell wachsende Zellen nach der Trypsinisierung in 800 $\mu \mathrm{l}$ Elektroporationspuffer und $50 \mu \mathrm{g}$ linearisierte DNA eingesetzt. Die linearisierte Konstrukt-DNA wurde zunächst mit Phenol/ Chloroform extrahiert, mit 100\%igem Ethanol präzipitiert und zuletzt in 70\%igem Ethanol gewaschen. Aus Sterilitätsgründen wurde das DNA-Pellet bei RT unter der Sterilbank luftgetrocknet und in $100 \mu$ Elektroporationspuffer aufgenommen. Die ES-Zellen wurden nach der Trypsinisierung in 9 ml Elektroporationspuffer gewaschen, in einer Neubauer-Zählkammer ausgezählt und nach erneuter Zentrifugation in einem Volumen von $700 \mu$ l Elektroporationspuffer aufgenommen. Die Suspension wurde in einer Küvette (Gene Pulser Cuvette, $0.4 \mathrm{~cm}$, gap 50, BioRad) vereinigt und mit $240 \mathrm{~V}$ und $55 \mu \mathrm{F}$ bei RT elektroporiert (Gene Pulser, BioRad). Anschließend wurden die ES-Zellen für 20 min auf Eis inkubiert und dann in fünf $100 \mathrm{~mm}$ Kulturschalen auf embryonalen Feederzellen ausplattiert. Die Selektion in G418 (PositvSelektion) und Gancyclovir (Negativ-Selektion) begann nach 12 bis 16 Stunden. Die Gancyclovir-Selektion wurde nach 5 Tagen beendet, während die G418-Selektion bis zur Isolierung resistenter Klone am Tag 8-9 aufrechterhalten wurde. Zur Kontrolle der Elektroporationseffizienz wurden die Zellen einer Kulturschale lediglich mit G418 selektioniert. Die Effizienz der Elektroporation lag normalerweise bei einer von $10^{5}$ Zellen.

\subsection{Isolierung von ES-Zellklonen und deren Kryokonservierung}

Positive ES-Zellen wurden lichtmikroskopisch identifiziert. Resistente Kolonien wurden nach einer G418-Selektion über 8 bis 9 Tage isoliert. Dazu wurden die Kulturen einmal in PBS- 
Puffer gewaschen und mit $10 \mathrm{ml}$ PBS-Puffer überschichtet. Die Klone wurden mechanisch mit Hilfe einer sterilen Pipettenspitze von den umgebenden embryonalen Feederzellen getrennt und bei $37^{\circ} \mathrm{C}$ in 1x Trypsin/ EDTA in 96-Loch-Platten dissoziiert. Der enzymatische Verdau wurde nach 5 min durch Zugabe von $50 \mu \mathrm{l}$ ES-Zellmedium gestoppt. Die vereinzelten Klone wurden auf 24-Loch-Platten mit Feederzellen und frischem ES-Zellmedium übertragen und bei $37^{\circ} \mathrm{C}$ kultiviert. Nach 2 bis 3 Tagen wuchsen die Einzelklone zur Konfluenz und wurden erneut trypsinisiert. Eine Hälfte der Zellen wurde erneut auf Feederzellen ausgesät (master plate), während die andere Hälfte der Zellen auf einer Gelatine-behandelten Platte (duplicate plate) inkubiert wurde. Die auf Feederzellen wachsenden ES-zellen wurden nach Erreichen der Konfluenz mit $100 \mu \mathrm{T}$ Trypsin/ EDTA bei $37^{\circ} \mathrm{C}$ für 5 min dissoziiert, in 1 ml Kryogefäße (Nunc) überführt und nach Zugabe von $100 \mu \mathrm{l}$ 2x Gefriermedium gemischt und bei $-80^{\circ} \mathrm{C}$ eingefroren. Die für die DNA-Isolierung vorgesehenen Zellen wurden ebenfalls bis zur Konfluenz kultiviert und anschließend der DNA-Extraktion unterworfen.

Homolog rekombinierte Klone wurden nach dem Auftauen bei $37^{\circ} \mathrm{C}$ in $10 \mathrm{ml}$ kaltes ESZellmedium gegeben, bei 270x g für 5 min abzentrifugiert und auf Feederzellen in 24-LochPlatten kultiviert. Nach Erreichen der Konfluenz wurden die Zellen vier Tage vor der Aggregation aufgetaut und kultiviert.

\subsection{Isolierung von 2.5 Tage alten Mausembryonen}

Mausembryonen des Stammes CD-1 wurden am Tag 2.5 nach der Befruchtung für die Aggregation mit rekombinierten ES-Zellen isoliert. Eine erfolgreiche Verpaarung läßt sich durch die Anwesenheit des Vaginalpfropfs (VP) bei begatteten Weibchen nachweisen. Dabei handelt es sich um Reste der Spermienflüssigkeit. Der Zeitpunkt des Vaginalpfropfs wird definitionsgemäß als 0.5 gerechnet. Es wurden jeweils zwei Weibchen mit einem Männchen verpaart. VP-positive Weibchen wurden für die Embryonenisolierung verwendet. Am Tag 2.5 wurden nach Abtöten der Mäuse die Ovidukte präpariert und mehrfach in warmen M2Medium gewaschen. Danach wurden sie in eine mit M2-Medium gefüllte $60 \mathrm{~mm}$ Kulturschale überführt. Unter dem Stereomikroskop wurden die Embryonen durch Ausspülen mittels einer mit M2-Medium gefüllten ausgezogenen Mundpipette aus dem Ovidukt herausgeschwemmt. Um Zell- und Gewebereste $\mathrm{zu}$ entfernen, wurden die 
ausgespülten Embryonen mehrfach in frisches M2-Medium übertragen. Nach einem weiteren Waschschritt in M16-Medium wurden die Embryonen in eine vorbereitete $30 \mathrm{~mm}$ Kulturschale in einen Tropfen M16-Medium unter Paraffinöl gegeben und bis zur Aggregation im Brutschrank bei $37^{\circ} \mathrm{C}$ und $5 \% \mathrm{CO}_{2}$ kultiviert. Im Durchschnitt wurden pro Maus etwa 6-8 Embryonen isoliert.

\subsection{Aggregation von ES-Zellen}

Die isolierten 2.5 Tage alten Mausembryonen mußten vor der Aggregation mit den rekombinierten ES-Zellen von ihrer Zona pellucida befreit werden. Sie wurden deshalb in einem Tropfen Tyrode-Lösung unter Öl für etwa 1 min durch mehrfaches Ein- und Aussaugen mit der Mundpipette behandelt. Das Auflösen der Zona pellucida wurde durch das Stereomikroskop verfolgt. Die freien Embryonen wurden anschließend dreimal in frischem M16-Medium gewaschen und in die für die Aggregation vorgesehene $30 \mathrm{~mm}$ Kulturschale in einen Tropfen M16-Medium übertragen. In dieser Schale befinden sich 10 bis 12 Tropfen M16-Medium, welche mit Paraffinöl überschichtet sind. In den Boden der Schale innerhalb eines jeden Tropfens werden mit einem feinen Bolzen kleine Vertiefungen eingestanzt, in denen die Embryonen mit den ES-Zellen aggregiert werden. Die Aggregation erfolgte nach der 'Sandwich'-Methode, d.h. zwischen zwei 2.5 Tage alte Embryonen wurden etwa 8-12 ES-Zellen gepackt und über Nacht kultiviert. Die rekombinierten ES-zellen wurden vier Tage vor der Aggregation auf Feederzellen ausgesät, zwei Tage später in subkonfluentem Zustand trypsinisiert und auf zwei $30 \mathrm{~mm}$-Kulturschalen auf Feederzellen verteilt. Am Tag der Aggregation wurden die ES-zellen nur unvollständig mit 1x Trypsin/ EDTA dissoziiert ( 3 min bei $37^{\circ} \mathrm{C}$ ) und in ein Schale mit M16-Medium übertragen. Jeweils ein ES-Zellhaufen wurde auf einen Embryo gelegt und mit dem zweiten Embryo bedeckt. Anschließend wurden die Aggregate vorsichtig in den Inkubator verbracht und über Nacht bei $37^{\circ} \mathrm{C}$ und $5 \% \mathrm{CO}_{2}$ bis zum Retransfer kultiviert.

$\begin{array}{lrl}\text { Tyrode's Säure: } \quad & 800 \mathrm{mg} & \mathrm{NaCl} \\ 20 \mathrm{mg} & \mathrm{KCl} \\ 24 \mathrm{mg} & \mathrm{CaCl}_{2} \cdot 2 \mathrm{H}_{2} \mathrm{O} \\ 10 \mathrm{mg} & \mathrm{MgCl}_{2} \cdot 6 \mathrm{H}_{2} \mathrm{O}\end{array}$




\author{
$100 \mathrm{mg}$ Glocose \\ $400 \mathrm{mg}$ Polyvinylpyrrolidon \\ ad $100 \mathrm{ml}$ mit $\mathrm{dH}_{2} \mathrm{O}(\mathrm{pH} 2.5$ mit $5 \mathrm{M} \mathrm{HCl})$
}

\title{
26.6. Embryo-Transfer in pseudoträchtige Mäuse
}

Pseudoträchtige Weibchen des Stammes NMRI wurden durch die Verpaarung mit vasektomierten NMRI-Männchen gewonnen. Für den Embryonen-Retransfer wurden Weibchen am Tag 3.5 verwendet. Nach Betäubung der Maus wurde auf einer Seite der Rückenhaut ein $1 \mathrm{~cm}$ langer Schnitt auf Höhe der Nieren gesetzt. Über dem rötlich durchscheinendem Ovar wurde ein kleines Loch in die Unterhaut geschnitten und das Ovar mit einer Pinzette am anliegenden Fettgewebe herausgezogen. Mit Hilfe einer feinen Kanüle wurde in das nun freiliegende Uterushorn ein kleines Loch eingebracht. Die über Nacht kultivierten ES-Zellaggregate wurden mit einer fein ausgezogenen Mundpipette aus den Vertiefungen der Kulturschale herausgespült und mit möglichst wenig Medium in der Spitze der Pipette aufgenommen. Dabei wurden nur Aggregate berücksichtigt, die eindeutig das Blastocysten-Stadium erreicht hatten. Die Pipette wurde dann durch das Loch in den Uterus eingeführt und vorsichtig ausgeblasen. Durchschnittlich wurden etwa 10-12 Aggregate sowie

2-3 Wildtyp-Embryonen pro Maus übertragen. Nach erfolgtem Retransfer wurden die Wundränder aneinander gelegt und mit einer Klammer verschlossen. Nach Desinfektion der Wunde wurde die Maus bis zum Erwachen auf eine Wärmeplatte gelegt.

\subsection{Identifizierung von Chimären}

Chimären wurden anhand des Agouti-Fellmarkers identifiziert. Männliche Mäuse mit einem Chimerismus von mindestens 50\% wurden auf den Ausgangsstamm zurückgekreuzt. Agoutifarbene Nachkommen der F1-Generation wurden im Alter von drei Wochen in einer Southern-Analyse genotypisiert. 


\section{ERGEBNISSE}

\section{Isolierung der HASH-cDNA der Maus}

Eine partielle cDNA für das Gen HASH wurde im Rahmen von Experimenten isoliert, bei denen nach der cDNA für einen möglichen Transkriptionsfaktor des Proakrosingens gesucht wurde. Die cDNA wurde durch das Screenen einer Testis- $\lambda$ gt11-Expressionsbibliothek der Ratte mit einem Promotorfragment (F4) des Proakrosingens, an das im 'gel retardation assay' ein Protein aus Testisextrakten bindet, von Keime (1993) isoliert und von Aho (1997) und Shamsadin (1995) weiter bearbeitet. In weiteren 'gel retardation assays' konnten jedoch keine spezifischen Interaktionen zwischen dem Fragment F4 und den Fusionsproteinen aus HASH-cDNA nachgewiesen werden. Die nachfolgenden Expressionsanalysen mit HASHcDNA zeigten jedoch eine testisspezifische Expression des HASH-Gens bei Ratte und Maus. Durch Northern-Blot-Experimente konnte nachgewiesen werden, daß das HASH-Gen in Testis von Ratte und Maus exprimiert ist, und zwar mit drei Transkripten (2.9 Kb, 2.3 Kb und 1.5 Kb). Zusätzlich konnte eine schwache Expression des 2.9 Kb Transkriptes in Ovar und Thymus beider Spezies und in Placenta der Maus nachgewiesen werden. Aufgrund der Ergebnisse bei weiteren Northern-Blot-Analysen wurde angenommen, daß die drei Transkripte des HASH-Gens durch alternatives Spleißen entstehen. In dieser Arbeit sollte zunächst die cDNA des HASH-Gens vervollständigt und weiter charakterisiert werden.

\section{Charakterisierung und Vervollständigung der HASH-cDNA der Maus}

\subsection{Expressionsanalyse des HASH-Gens der Maus}

\subsubsection{Expression des HASH-Gens in verschiedenen adulten Geweben}


Um die Gewebespezifität der Expression des HASH-Gens zu analysieren, wurde das Northern-Blot-Experiment mit RNA aus verschiedenen Organen der adulten Maus durchgeführt. Dazu wurde Gesamt-RNA (je $20 \mu \mathrm{g}$ ) aus verschiedenen Organen der adulten Maus - Gehirn, Herz, Leber, Lunge, Milz, Muskel, Niere, Ovar, Placenta, Thymus und Testis - mit der radioaktiv markierten cDNA-Sonde H-800 (Abb. 7) hybridisiert (Abb. 1). Um die Integrität und Menge der untersuchten RNAs zu überprüfen, wurde der Northern-Blot mit der radioaktiv markierten cDNA-Sonde für den humanen Elongationsfaktor hEF-2 nachhybridisiert. Nach zweitägiger Exposition des Autoradiogramms zeigten sich drei Hybridisierungssignale in Testis-RNA mit einer Länge von $2.9 \mathrm{~Kb}, 2.3 \mathrm{~Kb}$ und $1.5 \mathrm{~Kb}$. In Ovar, Placenta und Thymus wurde nur das große Transkript von $2.9 \mathrm{~Kb}$ detektiert. In anderen getesteten Geweben konnten auch nach einwöchiger Exposition des Autoradiogramms keine HASH-Transkripte nachgewiesen werden.

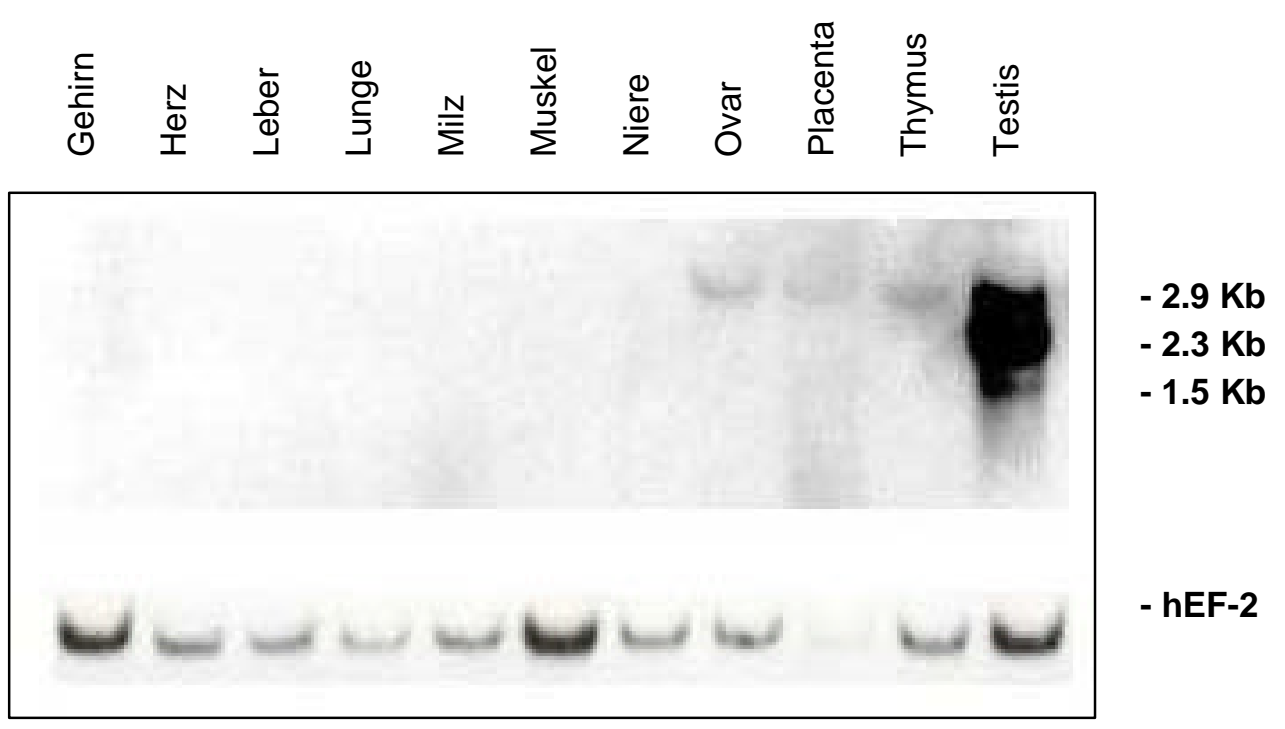

Abb. 1: Gewebespezifische Expression des HASH-Gens der Maus.

Gesamt-RNA (je $20 \mu \mathrm{g}$ ) aus Gehirn, Herz, Leber, Lunge, Milz, Muskel, Niere, Ovar, Placenta, Thymus und Testis wurden in einem denaturierenden Agarosegel aufgetrennt, auf eine Nitrocellulosemembran geblottet und mit der radioaktiv markierten cDNA-Sonde $\mathrm{H}-800$ (Abb. 7) hybridisiert. Die Expositionszeit des Autoradiogramms betrug ca. $36 \mathrm{~h}$. Die Integrität und Menge der aufgetragenen RNAs wurde durch Nachhybridisierung der Nitrocellulosemembran mit der Sonde für den humanen Elongationsfaktor hEF-2 überprüft. 


\subsubsection{Expression des HASH-Gens während der Testisentwicklung}

Für die Untersuchung zur Expression des HASH-Gens während der postnatalen Testisentwicklung wurde eine Northern-Blot-Hybridisierung mit Gesamt-RNA aus Testisgewebe von 5, 10, 15, 20, 25, 30, 40 und 60 Tage alten Mäusen durchgeführt. Nach elektrophoretischer Auftrennung in einem 1\%igen denaturierenden Agarosegel wurde die RNA auf eine Nitrocellulosemembran transferriert und mit der radioaktiv markierten $\mathrm{H}$ 800 cDNA-Sonde (Abb. 7) hybridisiert (Abb. 2).

Wie Abbbildung 2 zeigt, hybridisiert die H-800 HASH-cDNA mit allen getesteten RNAs. Das größte Transkript $(2.9 \mathrm{~Kb})$ ist in RNA aus allen Testisstadien vorhanden, während die zwei kleineren Transkripte $(2.3 \mathrm{~Kb}$ und $1.5 \mathrm{~Kb})$ zum Zeitpunkt der ersten haploiden Differenzierungsstadien im Testis nachweisbar sind. Das zeigt die keimzellspezifische Expression der zwei kleineren Transkripte mit starker Intensität des mittleren Transkriptes.

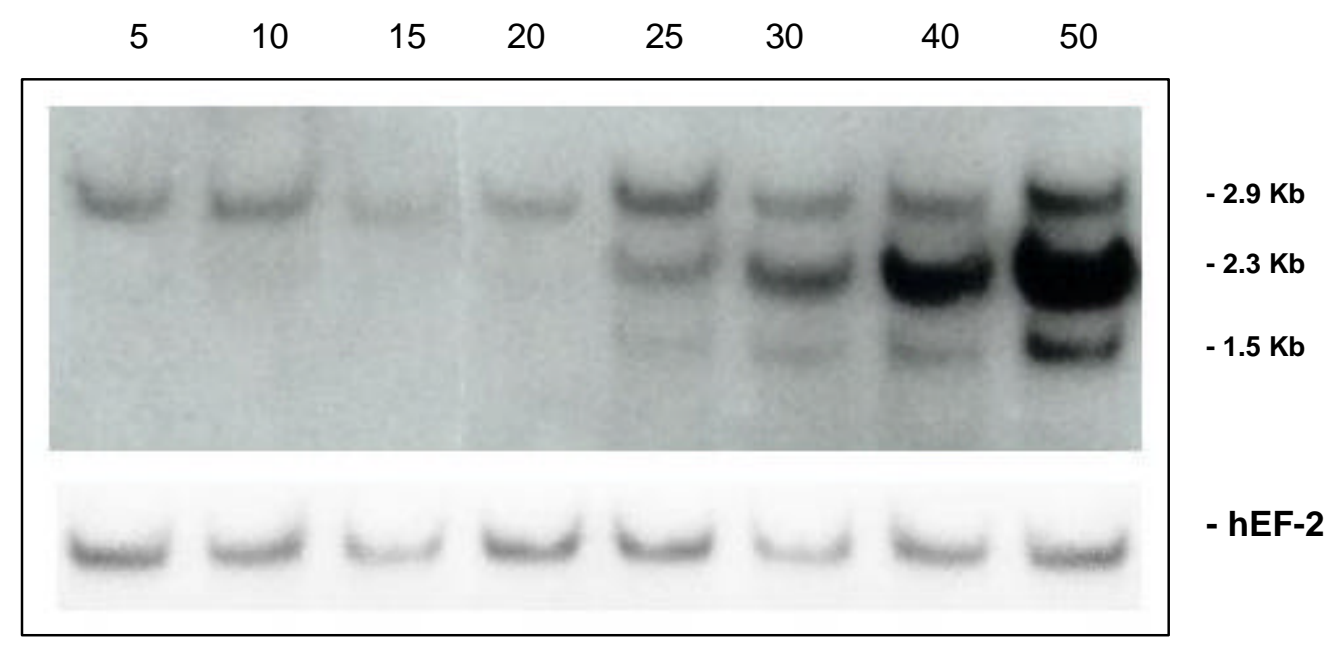

Abb. 2: Northern-Blot-Analyse der Expression des HASH-Gens der Maus in der postnatalen Testisentwicklung.

Gesamt-RNA (je $20 \mu \mathrm{g}$ ) aus Testes von 5, 10, 15, 20, 25, 3040 und 50 Tage alten Mäusen wurde nach denaturierender Gelelektrophorese auf eine Nitrocellulosemembran transferriert und mit der HASH cDNA Sonde H-800 (Abb. 7) hybridisiert. Die Expositionszeit des Autoradiogramms betrug ca. 36 h. Die Integrität und Menge der aufgetragenen RNAs wurde durch Nachhybridisierung der Nitrocellulosemembran mit der Sonde für den humanen Elongationsfaktor hEF-2 überprüft. 


\subsubsection{Analyse der Expression des HASH-Gens in Testes von verschiedenen Mausmutanten mit Keimzelldefekten}

Für die Untersuchung zur Expression des HASH-Gens bei verschiedenen Mutanten der Maus wurden jeweils $20 \mu \mathrm{g}$ Gesamt-RNA aus Testes der Mausmutanten W/W ${ }^{\mathrm{v}}$, Tfm/Y, olt/olt und qk/qk elektrophoretisch aufgetrennt, auf eine Nitrocellulosemembran transferriert und mit der radioaktiv markierten H-800 cDNA-Sonde (Abb. 7) hybridisiert.

Nach etwa zweitägiger Exposition konnten positive Hybridisierungssignale bei allen untersuchten RNAs nachgewiesen werden. Bei W/Wv- und Tfm/Y-Mutanten konnte nur das 2.9 Kb große Transkript gefunden werden. Das Fehlen der $2.3 \mathrm{~Kb}$ und $1.5 \mathrm{~Kb}$ großen Transkripte bei diesen Mutanten korreliert mit dem Fehlen von haploiden Keimzellen. In der Tfm/Y-Maus werden die Spermatogonien bis zur meiotischen Prophase differenziert, während die W/W ${ }^{\mathrm{v}}$-Maus keine Spermatogonien besitzt. Bei olt/olt- und qk/qk-Mutanten sind alle drei HASH-Transkripte zu identifizieren. In diesen Mutanten erfolgt die Spermatogenese bis zu haploiden Spermatiden. Das heißt, daß die zwei kleineren Transkripte $(2.3 \mathrm{~Kb}$ und 1.5 $\mathrm{Kb}$ ) erst in haploiden Keimzellen exprimiert werden (daher werden sie im folgenden als „HASHgerms“ bezeichnet), während das große Transkript (2.9 Kb) nur in somatischen Geweben nachweisbar ist (daher als „HASHsoma“ bezeichnet).

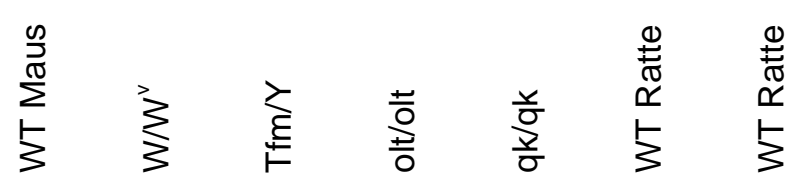

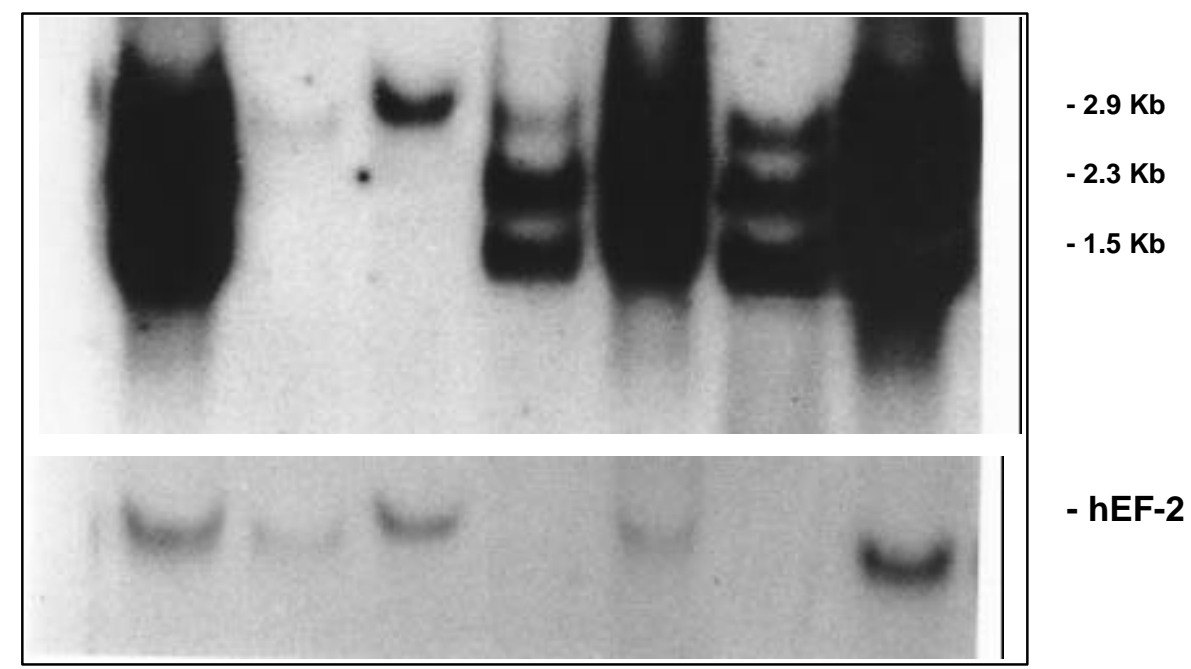


Abb. 3: Northern-Blot-Analyse zur Expression des HASH-Gens im Testis von verschiedenen Mutanten mit Keimzelldefekten.

Jeweils $20 \mu \mathrm{g}$ Gesamt-RNA aus dem Testis verschiedener Mutanten (W/W-, Tfm/Y, olt/olt, qk/qkMaus) sowie von Wildtyp-Maus und-Ratte (WT) wurde mit der HASH-cDNA-Sonde H-800 (Abb. 7) hybridisiert. Die Kontrolle der verwendeten RNAs wurde durch eine Nachhybridisierung der Membran mit der cDNA für den humanen Elongationsfaktor hEF-2 durchgeführt.

\subsubsection{Embryonale Expression des HASH-Gens der Maus}

Wie im Abschnitt 2.1. erwähnt wurde, wird HASHsoma in verschiedenen adulten Geweben einschließlich Testis, Ovar, Thymus und Gehirn exprimiert. Durch die Northern-Blot-Analyse wurde nachgewiesen, daß die $2.9 \mathrm{~Kb}$ große HASH-mRNA in kultivierten ES-Zellen transkribiert ist (Daten nicht gezeigt). Außerdem zeigte der Vergleich der HASH-cDNASequenz der Maus mit den cDNA-Sequenzen in Datenbanken, daß eine große Anzahl der embryonalen EST-Klone mit der HASH-cDNA-Sequenz identisch sind. Daher wurde die Expression des HASH-Gens während der embryonalen Entwicklung untersucht.

\subsubsection{Untersuchung der Expression des HASH-Gens während der Embryonalenentwicklung mittels RT-PCR}

Um Information über die Expression des HASH-Gens während der embryonalen Entwicklung zu erhalten, wurde zunächst die RT-PCR mit Gesamt-RNA aus Blastocysten, 8.5-, 9.5-, 10.5-, 11.5-, 12.5-, 13.5- und 14.5-Tage alten Embryonen durchgeführt. Es wurde $5 \mu \mathrm{g}$ der isolierten RNA revers transkribiert und $200 \mathrm{ng}$ der cDNA für die PCR unter Verwendung der genspezifischen Forward-Primer HA25 und ReversePrimer HA42R (s. Anhang), deren Sequenzen in Exon 11 und 13 lokalisiert sind, eingesetzt. Die 210 Bp großen Amplifikate ließen sich in Blastocysten, 8.5-, 9.5-, 10.5-, 11.5- und 12.5- 
Tage alten Embryonen nachweisen (Abb. 4). Bei 13.5-Tage alten Embryonen wurde ein schwaches Signal detektiert, während bei 14.5-Tage alten Embryonen kein Signal erhalten wurde. Die Integrität der verwendeten RNAs wurde nachfolgend durch die Amplifikation der mRNA für das Gen der Hypoxanthin-Phosphoribosyltransferase (HPRT) mit den Primern HPRT-F und HPRT-R überprüft.

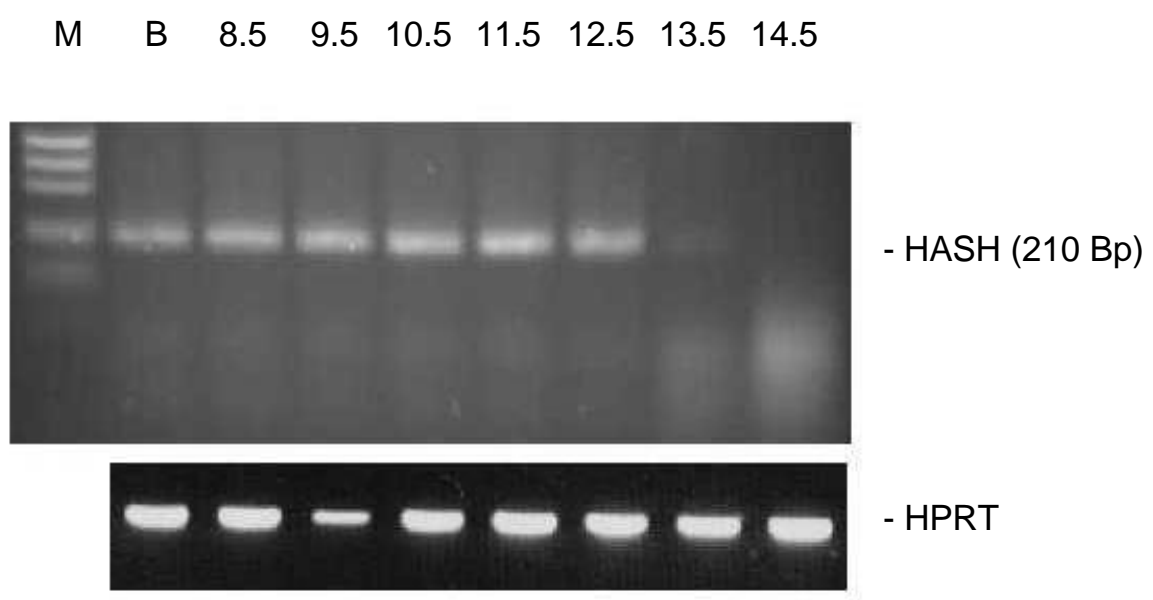

Abb. 4: Expressionsanalyse des HASH-Gens der Maus während der Embryonalentwicklung mittels RT-

PCR.

Gelektrophoretische Auftrennung der PCR-Produkte (210 Bp), die durch RT-PCR unter Verwendung der HASH-spezifischen Forward-Primer HA25 und Reverse-Primer HA42R amplifiziert wurden. Die 210 Bp großen Amplifikate wurden in Blastocysten (B), 8.5-, 9.5-, 10.5-, 11.5-, 12.5- und 13.5-Tage alten Embryonen nachgewiesen. Die Integrität der verwendeten RNAs wurde nachfolgend durch die Amplifikation der mRNA für das Gen der Hypoxanthin-Phosphoribosyltransferase (HPRT) mit den Primern HPRT-F und HPRT-R überprüft. 


\subsubsection{Identifizierung des Expressionsmusters des HASH-Gens während der Embryonalenentwicklung mittels 'whole mount'-in situ-Hybridisierung}

Aus dem Ergebnis der Expressionsuntersuchung durch RT-PCR während der embryonalen Entwicklung stellte sich folgende Frage: wo exprimiert das HASHGen im Embryo? Um diese Frage zu beantworten, wurde die 'whole mount'- in situHybridisierung durchgeführt. Dazu wurden 9.5- und 10.5-Tage alte Embryonen präpariert und mit einer Digoxigenin-markierten 'antisense' und 'sense' cDNA-Sonde H1.2, die die Nukleotidsequenz von 648 bis 1880 der HASH-cDNA enthält (Abb. 16), hybridisiert. Dabei zeigte die Hybridisierung mit sowohl 'antisense'- als auch 'sense'-markierter Sonde einen hohen Hintergrund (Daten nicht gezeigt). Daher wurde eine neue Digoxigeninmarkierte 'antisense' und 'sense' cDNA-Sonde H-800 (Abb. 7), die die Nukleotidsequenz von 1881 bis 2678 der HASH-cDNA enthält (Abb. 16), synthetisiert und für die 'whole mount'- in situ-Hybridisierung eingesetzt (Abb. 5). Hierbei wurden Hybridisierungssignale hauptsächlich im Neuralrohr und in den Somiten bei 9.5- und 10.5-Tage alten Embryonen beobachtet (A, B, C und D in Abb. 5). Bei 10.5-Tage alten Embryonen wurde ein spezifisches Signal nur in der distalen Region der Beinknospe detektiert (Abb. 5A, I). Für die weitere Differenzierung der Expressionstopografie wurden die Embryonen im 2.5\%igen Agarosegel eingebettet und dann transversal (E-I in Abb. 5) bzw. sagital (C und D) geschnitten.

In Sagitalschnitten bei 9.5 (C)- und 10.5 (D)-Tage alten Embryonen wurde die Hybridisierung im gesamten Neuralrohr von kaudal bis rostral beobachtet. In den Transversalschnitten sieht man nach Vergrößerung ein deutliches Hybridisierungssignal im dorsalen Bereich des Neuralrohres (F, G und $H$ ). In Abbildung $F$ wird das Hybridisierungssignal im Notochord gezeigt. In Abbildung 5I ist das auf dem distalen Bereich der Beinknospe eingeschänkte Hybridisierungssignal mit Pfeil gekennzeichnet. 


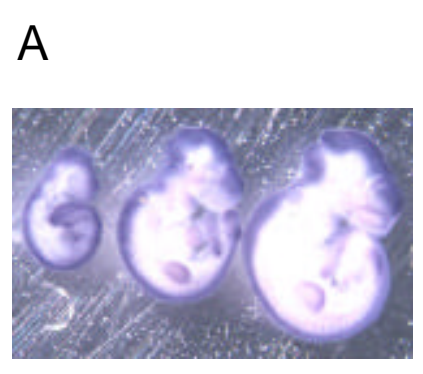

B

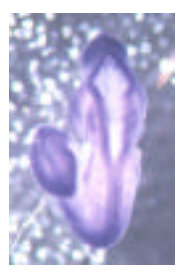

C

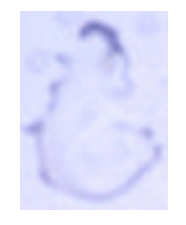

D

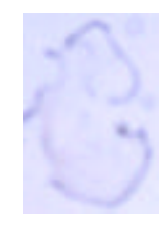

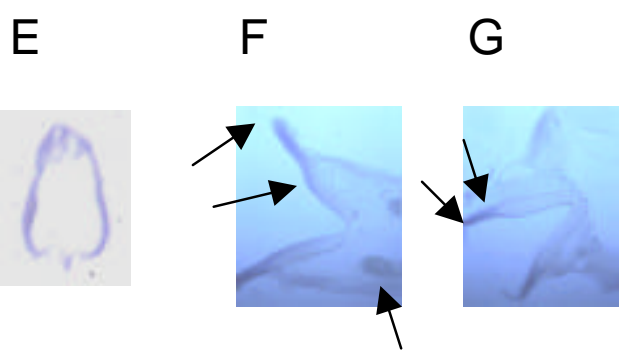

$\mathrm{N}$

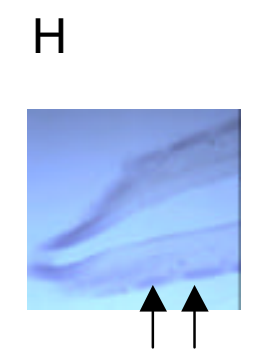

S

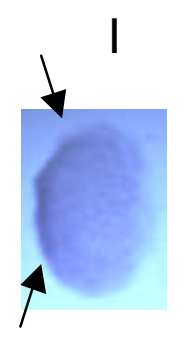

Abb. 5: 'Whole mount' -in situ-Hybridisierung.

Für die 'whole mount'-in situ-Hybridisierung wurden 9.5- und 10.5-Tage alte Embryonen präpariert und und mit einer Digoxigenin-markierten 'antisense' und 'sense' CDNA-Sonde H-800 (Abb. 7), die die Nukleotidsequenz von 1881 bis 2678 der HASH-cDNA enthält, hybridisiert.

A. Rechte Seite der etwa 9-, 9,5- und 10.5-Tage alten Embryonen, die mit einer Digoxigeninmarkierten 'antisense' cDNA-Sonde $\mathrm{H}-800$ hybridisiert wurden.

B. Dorsale Ansicht des 10.5-Tage alten Embryos aus A.

C und D. Sagitalschnitte von 9.5 (C)- und 10.5 (D)-Tage alten Embryonen.

E - I. Transversalschnitte eines 10.5-Tage-alten Embryos.

$N=$ Notochord

$S=$ Somit 


\subsection{Untersuchung zum alternativen Spleißen}

Southern-Blot-Analyse haben ergeben, daß das HASH-Gen im Rattengenom als 'single copy' Gen vorliegt (Aho, 1997). Um die drei unterschiedlich langen HASH-mRNAs zu erklären, kommen verschiedene Möglichkeiten in Betracht: 1. unterschiedlich lange Poly(A)Schwänze; 2. das 3'-alternative Spleißen; 3. das intern-alternative Spleißen; 4. die Anwesenheit von drei verschiedenen Promotoren. Um diese Möglichkeiten zu prüfen, wurden verschiedene Experimente durchgeführt.

\subsubsection{Identifizierung der Länge der Poly(A)-Schwänze der drei HASH-Transkripte}

Nach Beobachtungen von Gold und Hecht (1981) kann ein ungewöhlich langer Poly(A)Schwanz für die Translationsregulation haploid exprimierter Transkripte im Testis wichtig sein. Daher wurde untersucht, ob der Unterschied in der Länge der drei HASH-Transkripte auf unterschiedlich lange Poly(A)-Schwänze zurückzuführen ist. Dazu war es notwendig, die exakten Längen der Poly(A)-Schwänze der drei HASH-cDNAs, insbesondere der HASHgerms, zu bestimmen.

Für diese Zwecke wurde Gesamt-RNA aus Testis mit RNaseH verdaut und anschließend eine Northern-Blot-Hybridisierung durchgeführt. Dazu wurden drei getrennte Ansätze von $10 \mu \mathrm{g}$ Maustestis Gesamt-RNA mit $2 \mu \mathrm{g}$ Oligo $(\mathrm{dT})_{12-18}$ versetzt und für $3 \mathrm{~min}$ bei $65^{\circ} \mathrm{C}$ inkubiert. Anschließend wurde den Reaktionsansätzen 0.2 Vol. 5x Ribonukleasepuffer $\mathrm{H}$ zugegeben und für 15 min auf Eis gestellt. Die Proben wurden durch Zugabe von 1 $\mu \mathrm{l}$ RaseH (BRL, $12 \mathrm{U} / \mu \mathrm{l}$ ) bei $37^{\circ} \mathrm{C}$ verdaut (Reaktionszeit 0-, 30- und $60 \mathrm{~min}$ ) und danach sofort einer Phenol/Chloroform-Extraktion unterworfen. Die Überstände wurden mit 0.1 Vol. $3 \mathrm{M} \mathrm{NaAc}(\mathrm{pH} 4.8)$ und $2.5 \mathrm{Vol}$. Ethanol für $20 \mathrm{~min}$ bei $-70^{\circ} \mathrm{C}$ präzipitiert und die verdauten RNA-Moleküle durch Zentrifugation (13000x g, $15 \mathrm{~min}, 4^{\circ} \mathrm{C}$ ) sedimentiert. Danach wurden die Reaktionsansätze mit 70\%igem Ethanol gewaschen, behandelt und gelelektrophoretisch aufgetrennt. Nach dem Transfer auf eine Nitrocellulosemembran wurde die RNA mit der radioaktiv markierten HASH-cDNA-Sonde H-800 (Abb. 7) hybridisiert (Abb. 6). Dieses Northern-Blot-Experiment, nach jeweils 30min (Bahn 3) und 60min (Bahn 4) Inkubation mit RNaseH, ergab, daß die Länge der Poly(A)-Schwänze der drei HASH- 
Transkripte maximal 100 Bp beträgt. Die Unterschiede der drei HASH-Transkripte ist nicht auf die Länge der Poly(A)-Schwänze zurückzuführen. Im Vergleich mit dem RNA-Marker konnte festgestellt werden, daß die drei HASH Transkripte nach dem RNase H-Verdau eine Länge von 2.6 Kb („HASHsoma“ oder „HASHsoma2.6“), 1.8 Kb („HASHgerm1.8“) und $1.2 \mathrm{~Kb}($,HASHgerm1.2“) haben.
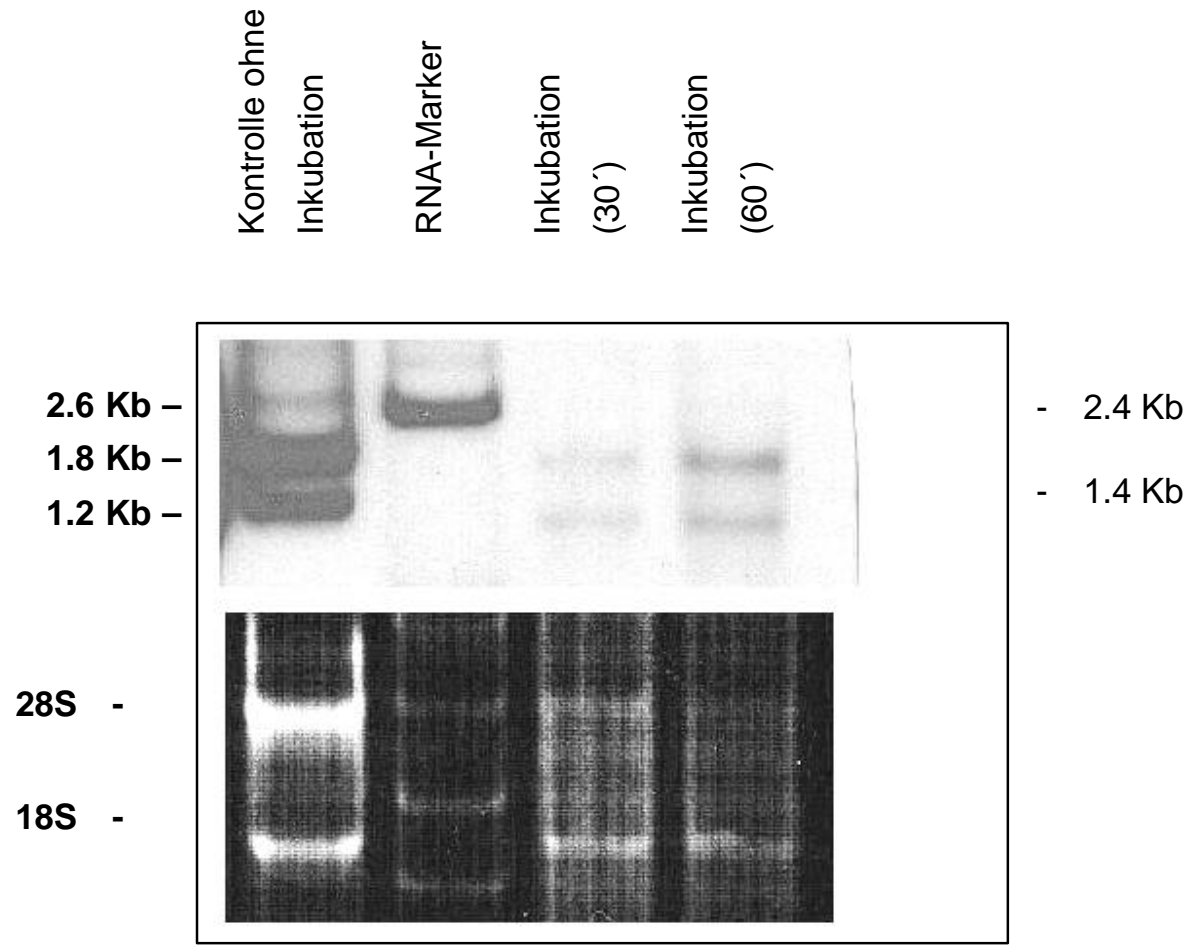

Abb. 6: Northern-Blot-Hybridisierung zur Identifizierung der Größe bzw. der Länge des Poly(A)Schwanzes der drei HASH-Transkripte der Maus.

$10 \mu \mathrm{g}$ Maustestis Gesamt-RNA wurde mit $2 \mu \mathrm{g}$ Oligo $(d T)_{12-18}$ versetzt und für 3 min bei $65^{\circ} \mathrm{C}$ inkubiert. Anschließend wurde den Reaktionsansätzen 0.2 Vol. $5 x$ Ribonukleasepuffer $H$ zugegeben und für 15 min auf Eis gestellt. Die Proben wurden durch Zugabe von $1 \mu$ RNaseH (BRL, $12 \mathrm{U} / \mu \mathrm{l}$ ) bei $37^{\circ} \mathrm{C}$ für $0 \mathrm{~min}$ (Kontrolle), $30 \mathrm{~min}$ (Bahn 3) und $60 \mathrm{~min}$ (Bahn 4) verdaut und anschließend nach denaturierender Gelelektrophorese auf eine Nitrocellulosemembran transferriert und mit der HASH cDNA Sonde H-800 (Abb. 7) hybridisiert. Die Expositionszeit des Autoradiogramms betrug ca. $24 \mathrm{~h}$. Zur Kontrolle der RNA-Proben wurde das Gel mit Ethidiumbromid angefärbt, um die 28S- und 18S-RNAs sichtbar zu machen. 


\subsection{2. $3^{\prime}$-alternatives Spleißen}

In der 3'-flankierenden Region des HASH-Gens der Ratte wurde ein zweites Polyadenylierungssignal (AATAAA) identifiziert, das vom ersten Polyadenylierungssignal (ATGAAA) 705 Bp entfernt ist. Das Vorhandensein von zwei Polyadenylierungssignalen führte zur Annahme, daß die Unterschiede der HASH-mRNAs auf der Benutzung verschiedener Polyadenylierungssignale beruhen könnte. Es wurde diskutiert, ob die zwei Poly(A)-Signale mit dem alternativen Spleißen und der gewebespezifischen Expression des HASH-Gens im Zusammenhang stehen könnten. Um diese Annahme zu überprüfen, wurde zunächst für die Maus das cDNA-Fragment zwischen den Poly(A)-Signalen durch RTPCR amplifiziert und anschließend für die Northern-Blot-Analyse verwendet (Abb. 8).

Für die Amplifikation des 3'-Fragmentes wurden der Forward-Primer HA42 (s. Anhang), der vor dem ersten Polyadenylierungssignal lokalisiert ist und Poly(dT) als Reverse-Primer eingesetzt. Um die spezifische Sonde zwischen den zwei Poly(A)-Signalen herzustellen, wurde dann die Nested-PCR mit den Primern H3F1 und H3R1 (s. Anhang), die jeweils nach dem ersten bzw. vor dem zweiten Poly(A)-Signal lokalisiert sind, durchgeführt (Abb. 7). Um eine Kontamination zu vermeiden, wurden die PCR-Amplifikate (E13B) in den pGEM-T Vektor kloniert, sequenziert, dann wieder mit Enzymen herausgeschnitten und anschließend nach einer Elektrophorese aus dem Gel extrahiert. Das aufgereinigte cDNA-Fragment E13B zwischen den zwei Poly(A)-Signalen wurde radioaktiv markiert und für die Northern-BlotHybridisierung als Sonde verwendet (Bahn 8 in Abb. 8). Hierbei zeigte sich kein Hybridisierungsignal nach einwöchiger Exposition. Aus diesem Ergebnis konnte gefolgert werden, daß die Sequenz zwischen den zwei Polyadenylierungssignalen nicht transkribiert wird, also altenatives Spleißen in diesem Bereich der HASH-mRNA nicht realisiert ist. 


\subsubsection{Amplifikation der verschiedenen Exon-spezifischen cDNA-Fragmente mittels PCR bzw. RT-PCR}

Um zu überprüfen, ob die drei HASH-Transkripte durch internes alternatives Spleißen entstehen, wurden RT-PCR Experimente mit verschiedenen Exon-spezifischen Primern durchgeführt. Trotz mehrmaligen Versuchen wurde kein alternatives Spleißprodukt gefunden (nicht dokumentiert). Das könnte darauf hinweisen, daß die Gewebespezifität und Phasenspezifität der HASH-Transkripte auf die Nutzung verschiedener Promotoren zurückzuführen ist. Es wurden daher verschiedene Exon-spezifische Fragmente durch PCR amplifiziert (Abb. 7), um die cDNA Struktur der drei HASH-Transkripten weiter zu analysieren.

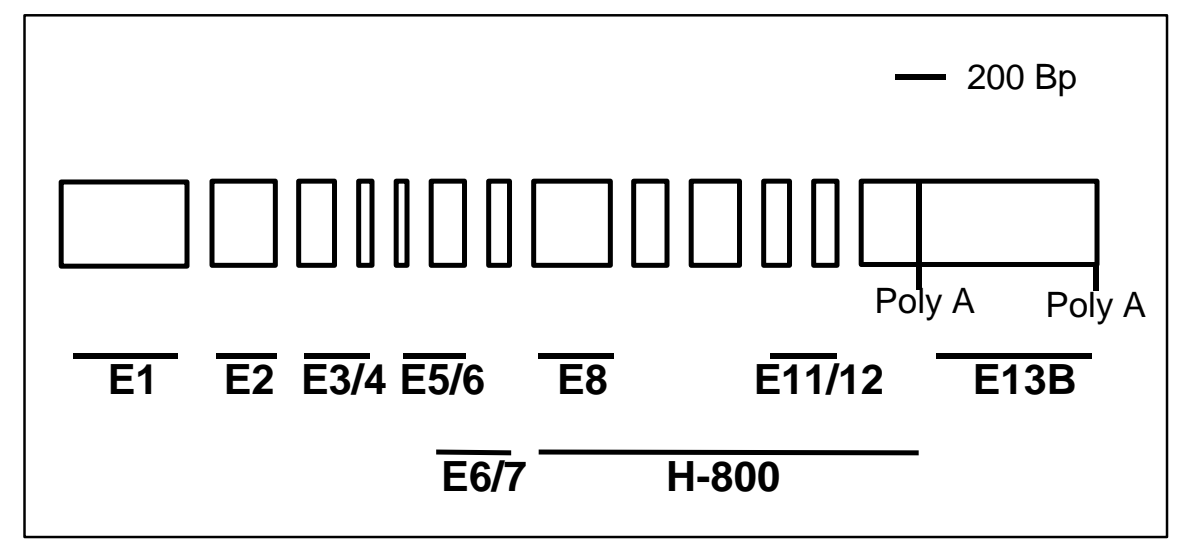

Abb. 7: Schematische Darstellung der durch PCR amplifizierten, Exon-spezifischen Fragmente.

Für die Exon-spezifische Amplifikation wurden folgende Primer (s. Anhang) eingesetzt: HA15 und HO10 für E1, HO7 und HO9 für E2, HO5 und HA71 für E3/4, HO3 und HA7 für E5/6, HA9 und H5R1 für E6/7, H5F1 und H5R2 für E8, HA25 und HA42R für E11/12, H3F1 und H3R1 für E13B. 


\subsubsection{Northern-Blot-Analysen mit den verschiedenen Exon-spezifischen cDNA- Fragmenten}

Um eine Kontamination zu vermeiden, wurden die PCR-Amplifikate in pGEM-T Vektor kloniert, sequenziert, dann wieder mit Enzymen herausgeschnitten und anschließend nach Elektrophorese aus dem Gel extrahiert. Die aufgereinigten Exon-spezifischen Fragmente wurden radioaktiv markiert und für Northern-Blot-Hybridisierungen als Sonden verwendet. Dabei wurde die cDNA-Sonde H-800 (Abb. 7), die mit allen drei HASHTranskripten hybridisiert, als Kontrolle benutzt.

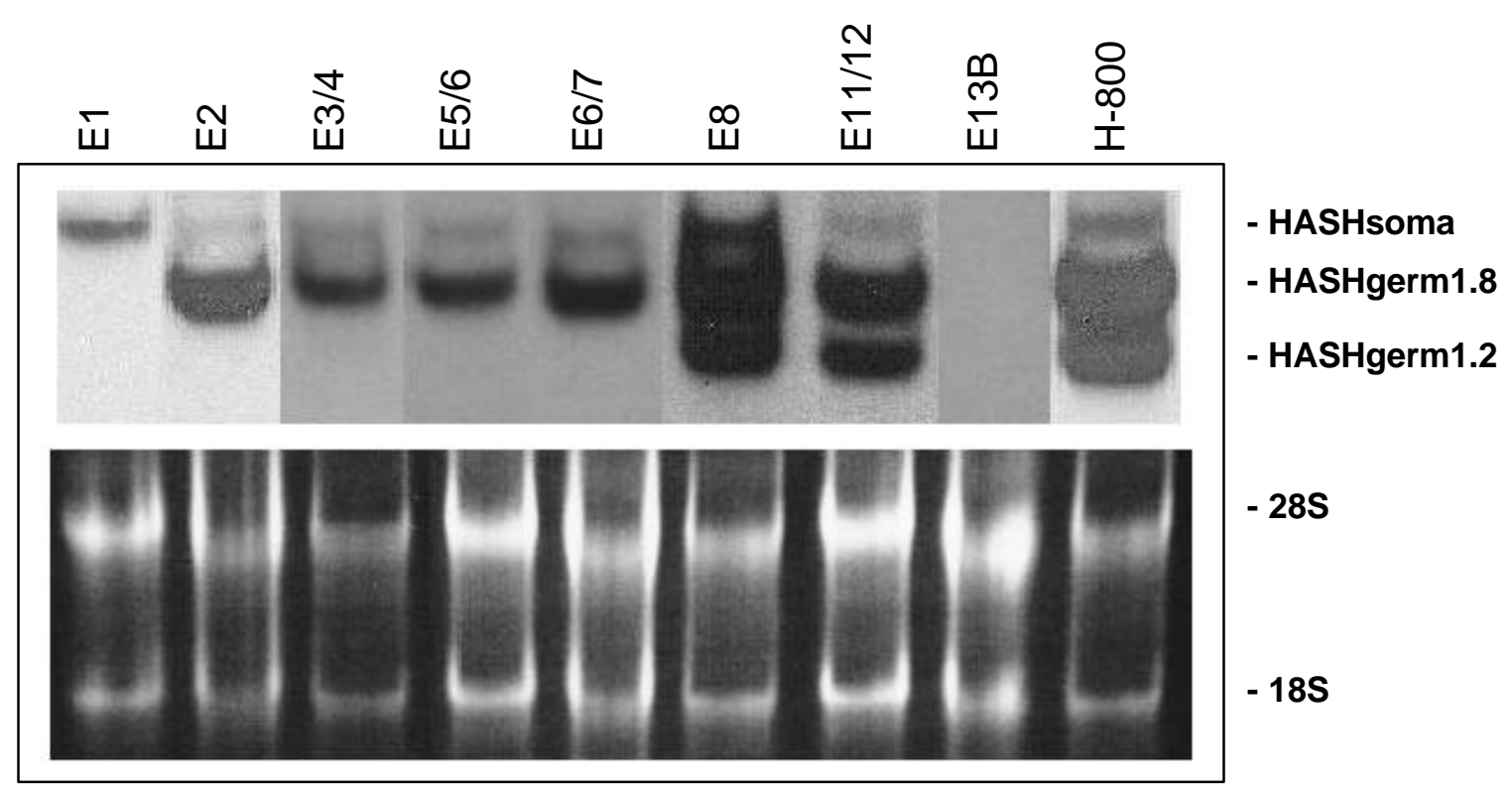

Abb. 8: Northern-Blot-Analyse zur Erklärung des alternativen Spleißen.

Gesamt-RNA (je $20 \mu \mathrm{g}$ ) aus Testes der adulten Maus wurde nach denaturierender Gelelektrophorese auf eine Nitrocellulosemembran transferriert und mit verschiedenen $\mathrm{HASH}$ Sonden (Abb. 7) hybridisiert. Die Expositionszeit des Autoradiogramms betrug etwa 16 bis $36 \mathrm{~h}$. Zur Kontrolle der RNA-Proben wurde das Gel mit Ethidiumbromid angefärbt, um die 28S- und 18S-RNAs sichtbar zu machen. 
Aus den Ergebnissen der Northern-Blot-Hybridisierungen mit verschiedenen Exonspezifischen Fragmenten kann gefolgert werden, daß Exon 8 bis Exon 12 in allen drei HASH-mRNAs vorhanden ist, während Exon 2 bis Exon 7 in HASHsoma und HASHgerm1.8, aber nicht in HASHgerm1.2 vorhanden ist. Weiterhin konnte Exon 1 nur in HASHsoma gefunden werden. Aufgrund der Analysen kann angenommen werden, daß die drei HASH-Transkripte nur im 5'-Ende unterschiedlich sind.

Aus den Ergebnissen der Experimente in III.2.2.2.-2.2.4. konnten folgende Informationen erhalten werden:

1. Die drei HASH-mRNAs haben ein gemeinsames Poly(A)-Signal.

2. Es gibt kein internes Spleißen in der HASH-mRNA.

3. Die drei HASH-Transkripte können durch drei verschiedene Promotoren zustandekommen.

4. Für HASHsoma fehlt cDNA Information von ca. 400 Bp in 5'-Richtung. 


\subsection{Versuche zur Identifizierung des $5^{\prime}$-Endes der drei HASH-mRNAs mit Hilfe der Marathon-RACE-PCR}

Für die Identifizierung des Transkriptionsstartpunktes der drei HASH-Transkripte wurde eine Primer-Extension durchgeführt. Dabei konnte kein gemeinsamer Transkriptionsstartpunkt für die drei HASH-mRNAs identifiziert werden (Daten nicht dokumentiert). Um weitere Informationen über den 5'-Bereich der drei HASH-cDNAs zu erhalten, wurde eine Marathon-RACE-PCR mit Testis-RNA durchgeführt. Für die Konstruktion der Maustestis cDNA-Bank unter Verwendung des Marathon RACE Kits (Clontech) wurde $1 \mu$ g Poly(A)angereicherte RNA aus adultem Testis der Maus eingesetzt und mit dem Poly(dT)-Primer revers transkribiert. Nach Ligation der partiell einzelsträngigen Linker (Adapter) an die Enden der cDNAs wurden $2 \mu$ Aliquots dieser Bank mit je einem genspezifischen und dem im Kit enthaltenen Adapter-Primer gescreent. Nach der Erst-Runden PCR wurde für die Amplifikation des 5'-Endes aus dem ersten Ansatz $1 \mu \mathrm{l}$ als Template für eine NestedPCR mit den genspezifischen, internen Primern eingesetzt.

\subsubsection{Versuch zur Isolierung des 5'-Endes der HASHsoma}

Für die Identifizierung des 5'-Endes der HASHsoma wurden der Adapter-Primer 1 (AP1) als Forward-Primer und e1_2fl (s. Anhang) als genspezifischer Reverse-Primer (Abb. 9) eingesetzt. Nach der Erst-Runden PCR wurde von den Reaktionsprodukten ein Aliquot von 5 $\mu \mathrm{l}$ gelelektrophoretisch über ein 1.5\%iges Agarosegel aufgetrennt. In einer Zweit-Runden PCR wurde für die Amplifikation des 5'-Endes aus dem ersten Ansatz $1 \mu$ als Template für eine Nested-PCR mit den Primern e1_1fl (Abb. 9; s. Anhang) und AP2 eingesetzt. Nach der Zweit-Runden PCR wurde von den Reaktionsprodukten ein Aliquot von $5 \mu \mathrm{l}$ gelelektrophoretisch über ein 1.5\%iges Agarosegel aufgetrennt (Abb. 10A). Nach dem Transfer der PCR-Produkte auf eine Nitrocellulosemembran wurde die DNA mit der radioaktiv makierten HASH-cDNA-Sonde E1 (Abb. 7) hybridisiert (Abb. 10B). 


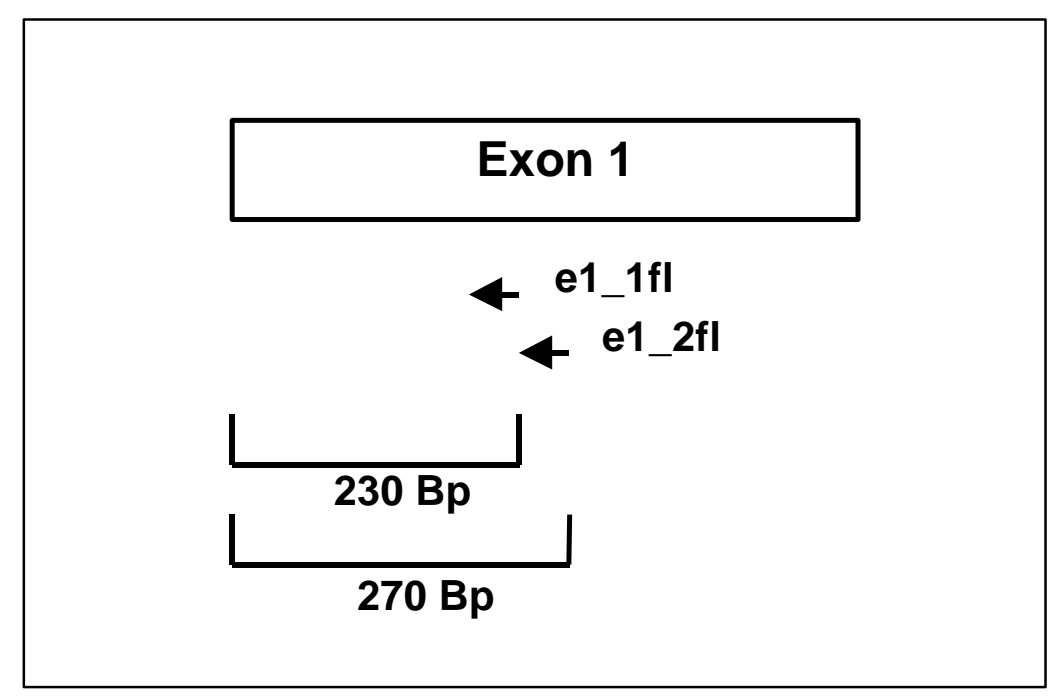

Abb. 9: Schematische Darstellung der zur Amplifikation des 5'-Endes der HASHsoma verwendeten Primer.

Die für die RACE-PCR des 5'-Endes der HASHsoma eingesetzten Primer e1_1fl und e1_2fl (s. Anhang), befinden sich 230 Bp bzw. 270 Bp downstream vom bekannten 5'-Ende des Exons 1 (502 Bp).

Wie Abbildung 10B zeigt, ergaben die Erst-Runden PCR und die Nested-PCR einen Pool (ca. $0.2-0.8 \mathrm{~Kb})$ der spezifischen Amplifikation. Um die längste cDNA-Information von HASHsoma zu erhalten, wurden die Amplifikate aus dem oberen Bereich (>600 Bp, mit Box markiert in Bahn 1 der Abbildung 10A) aus einem 1.0\%igen Agarosegel extrahiert und in den pGEM-T Vektor ligiert. Nach der Transformation wurden die Kolonien gescreent, um das längste Fragment zu erhalten. 


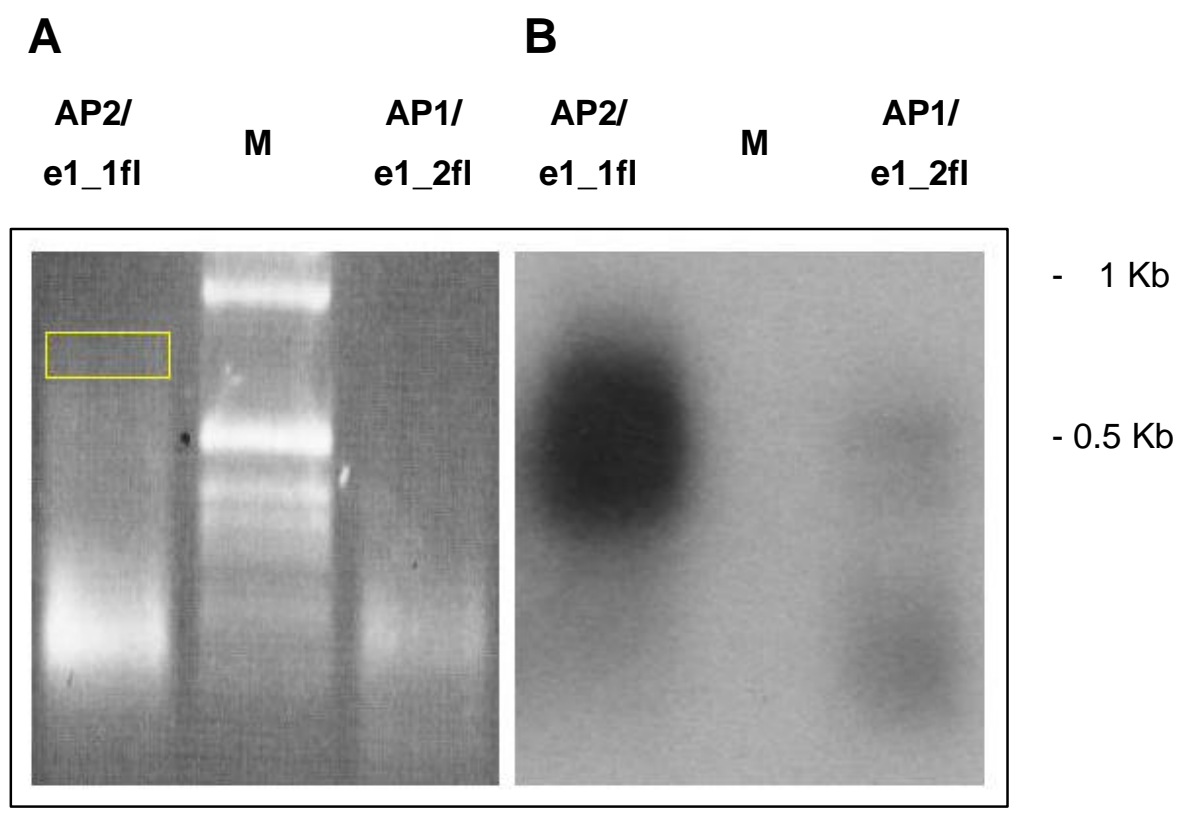

Abb. 10: Amplifikation des 5'-Endes der HASHsoma mit Hilfe der Marathon-PCR.

A. Elektrophoretische Auftrennung im 1.0\%igen Agarosegel nach der Erst (Bahn 3)- und Zweit (Bahn 1)-Runden Marathon-RACE-PCR. Um die längste cDNA-Information von HASHsoma zu erhalten, wurden die Amplifikate aus dem oberen Bereich (>600 Bp, markiert mit Box in Bahn 1) aus einem 1.0\%igen Agarosegel extrahiert.

B. Southern-Blot-Hybridisierung von Blot (A). Nach dem Transfer der PCR-Produkte auf eine Nitrocellulosemembran wurde die Amplifikations-DNA mit der radioaktiv makierten HASH-cDNASonde E1 (Abb. 7) hybridisiert. Die Expositionszeit des Autoradiogramms betrug etwa 30min.

In Abbildung 11A ist die neue cDNA Information von 5'-Upstream des Exons 1 schematisch dargestellt. Um zu üerprüfen, ob die neu erhaltene cDNA-Information tatsächlich in den HASH-Transkripten vorhanden ist, wurde eine Northern-Blot-Hybridisierung durchgeführt. Wie Abbildung 11 zeigt, hybridisierte die durch die 5'-Marathon-RACE-PCR erhaltene, neue cDNA E1A nur mit HASHsoma. Durch Sequenzierung des genomischen Klons wurde festgestellt, daß diese neue cDNA Information zum Exon 1 gehört. 
A

B

H-800 E1A

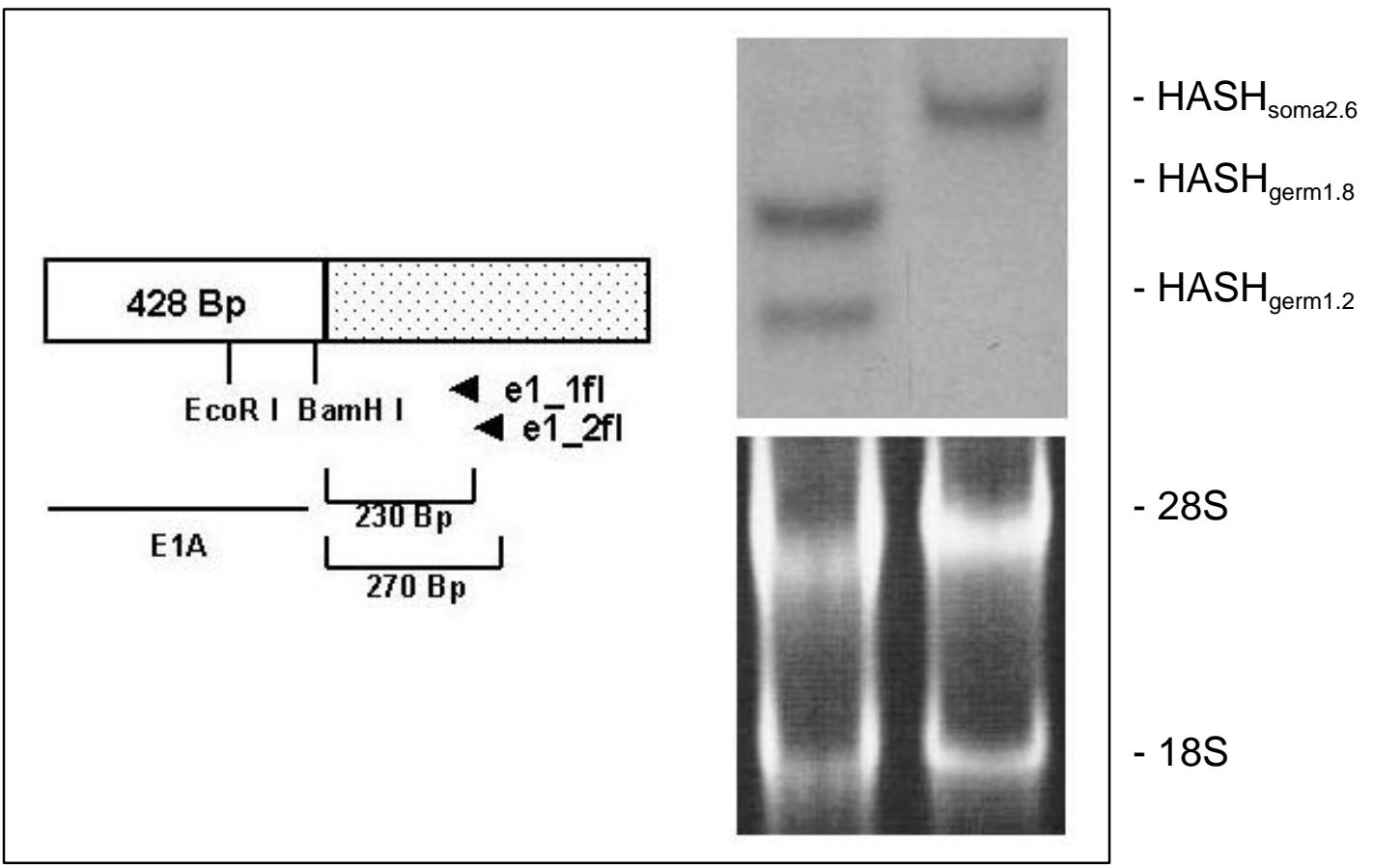

Abb. 11: Neue cDNA Information von 5'-Upstream des Exons 1 und Northern-Blot-Analyse

A. Schematische Darstellung der durch 5'-Marathon-RACE-PCR erhaltene, neue cDNA E1A.

B. Gesamt-RNA (je 10 mg) aus Testes der adulten Maus wurde nach denaturierender Gelelektrophorese auf eine Nitrocellulosemembran transferriert und mit der HASH-cDNASonde E1A (Abb.11A) hybridisiert. Hier wurde die cDNA-Sonde H-800 (Abb. 7), die mit allen drei HASH-Transkripten hybridisiert, als Kontrolle benutzt. Die Expositionszeit des Autoradiogramms betrug jeweils 16 bis $36 \mathrm{~h}$. Zur Kontrolle der RNA-Proben wurde das Gel mit Ethidiumbromid angefärbt, um die 28S- und 18S-RNAs sichtbar zu machen. 


\subsubsection{Versuch zur Isolierung des $5^{\prime}$-Endes der HASHgerm1.8}

Zur Identifizierung des 5'-Endes der HASHgerm1.8 wurde eine Marathon-RACE-PCR mit dem Adapter-Primer 1 (AP1) als Forward-Primer und HO6 als genspezifischem ReversePrimer (Abb. 12) eingesetzt. Nach der Erst-Runden PCR wurde von den Reaktionsprodukten ein Aliquot von $5 \mu \mathrm{l}$ gelelektrophoretisch über ein 1.5\%iges Agarosegel aufgetrennt. In einer Zweit-Runden PCR wurde für die Amplifikation des 5'-Endes aus dem ersten Ansatz $1 \mu \mathrm{l}$ als Template für eine Nested-PCR mit den Primern HO9 (Abb. 12) und AP2 eingesetzt. Nach der Zweit-Runden PCR wurde auch von den Reaktionsprodukten ein Aliquot von $5 \mu \mathrm{l}$ gelelektrophoretisch über ein 1.5\%iges Agarosegel aufgetrennt. Nach dem Transfer der PCRProdukte auf eine Nitrocellulosemembran wurde die DNA mit der radioaktiv makierten HASH-cDNA-Sonde E2 (Abb. 7) hybridisiert. Obwohl das Hybridisierungssignal kleiner als die erwartete Länge war, wurden die Amplifikate aus dem oberen Bereich (>200 Bp) aus einem 1.5\%igen Agarosegel extrahiert und in pGEM-T Vektor ligiert. Nach Transformation, Minipräparation und Sequenzierungsanalyse der Plasmid-DNA wurde festgestellt, daß alle Amplifikate innerhalb von Exon 2 abgebrochen waren. Aus den Ergebnissen dieses Experimentes konnte daher nicht ausgeschlossen werden, daß sich das 5'-Ende der HASHgerm1.8 doch innerhalb von Exon 2 befindet. Der Abbruch der PCRAmplifikate innerhalb von Exon 2 könnte aus dem hohem GC-Gehalt (87\%) in Exon 2 resultieren. 


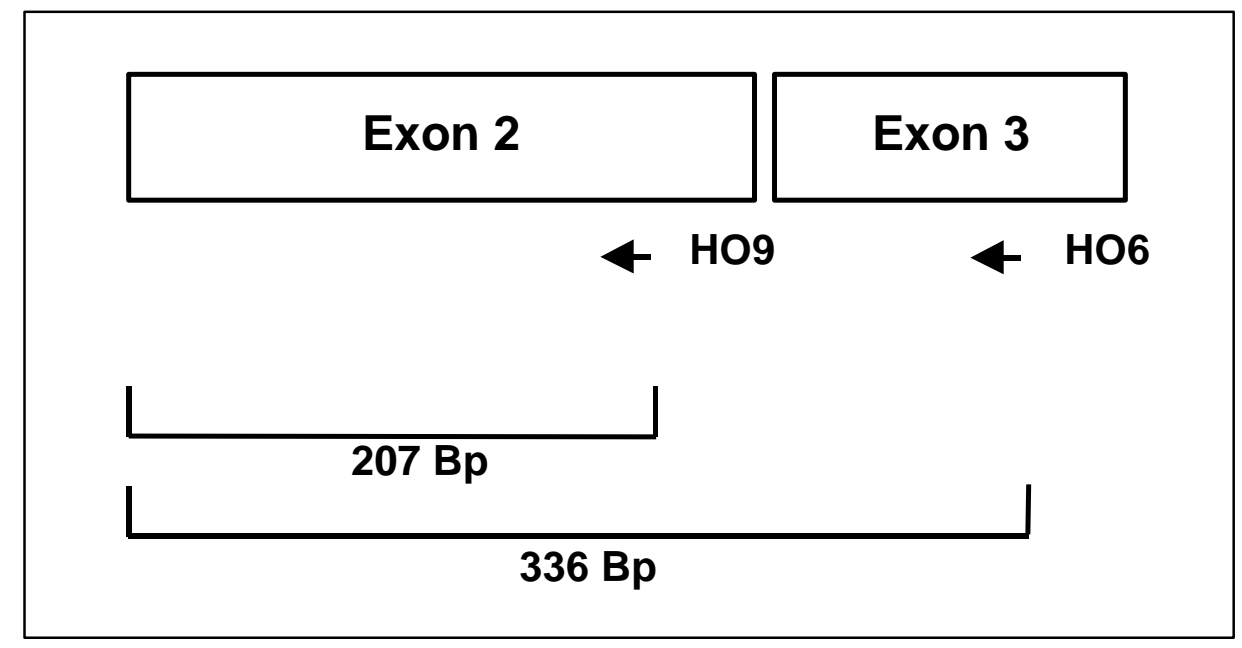

Abb. 12: Schematische Darstellung der zur Amplifikation des 5'-Endes der HASHgerm1.8 verwendeten Primern.

Die für die RACE-PCR des 5'-Endes der HASHgerm1.8 eingesetzten Primer, HO9 und HO6, befinden sich jeweils 207 Bp und 336 Bp downstream vom 5'-Ende des Exons 2. 


\subsubsection{Versuch zur Isolierung des $5^{\prime}$-Endes der HASHgerm1.2}

Zur Identifizierung des 5'-Endes der HASHgerm1.8 wurde eine Marathon-RACE-PCR mit dem Adapter-Primer 1 (AP1) als Forward-Primer und H5R2 als genspezifischem ReversePrimer (Abb. 13) eingesetzt. Nach der Erst-Runden PCR wurde von den Reaktionsprodukten ein Aliquot von $5 \mu$ gelelektrophoretisch über ein 1.5\%iges Agarosegel aufgetrennt. In einer Zweit-Runden PCR wurde für die Amplifikation des 5'-Endes aus dem ersten Ansatz $1 \mu$ als Template für eine Nested-PCR mit den Primern HO4 (Abb. 13) und AP2 eingesetzt. Nach der Zweit-Runden PCR wurde auch von den Reaktionsprodukten ein Aliquot von $5 \mu$ l gelelektrophoretisch über ein 1.5\%iges Agarosegel aufgetrennt. Nach dem Transfer der PCRProdukte auf eine Nitrocellulosemembran wurde die DNA mit der radioaktiv makierten HASH-cDNA-Sonde E8 (Abb. 7) hybridisiert.

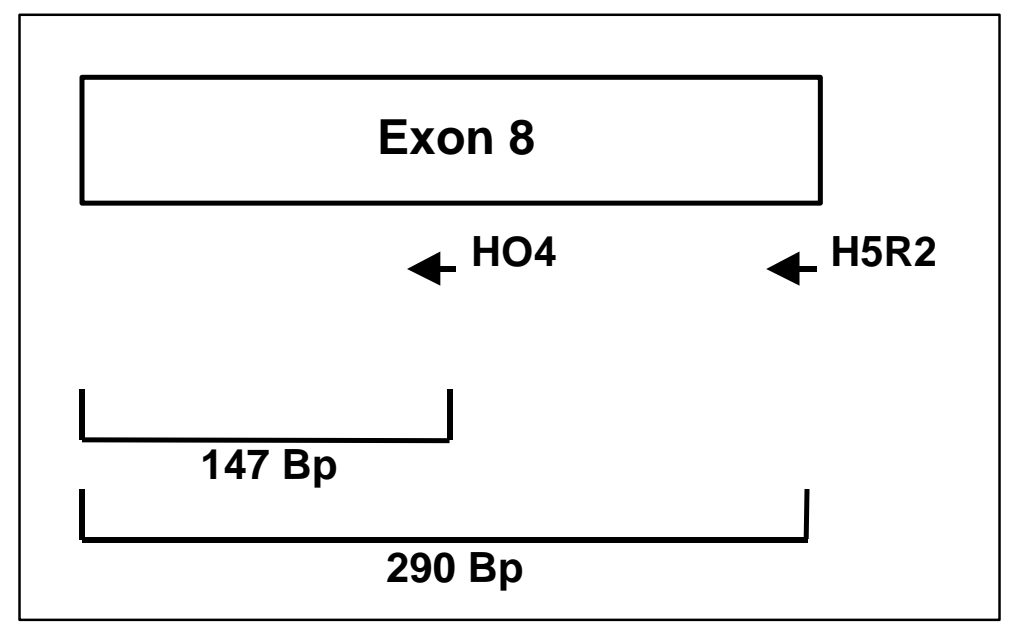

Abb. 13: Schematische Darstellung der zur Amplifikation des 5'-Endes der HASHgerm1.2 verwendeten Primern.

Die für die RACE-PCR des 5'-Endes der HASHgerm1.2 eingesetzten Primer, HO4 und H5R2, befinden sich jeweils $147 \mathrm{Bp}$ und 290 Bp downstream vom 5'-Ende des Exons 8. 
Um die längste cDNA-Information von HASHgerm1.2 zu erhalten, wurden die Amplifikate aus dem oberen Bereich (>150 Bp) aus einem 1.5\%igen Agarosegel extrahiert und in den pGEM-T Vektor ligiert. Nach der Transformation wurden Kolonien gescreent, um den Klon mit dem längsten Fragment zu isolieren. In Abbildung 14A ist die neue cDNA Information des Exons 8A schematisch dargestellt.

Um zu üerprüfen, ob die neu erhaltene cDNA-Information tatsächlich in den HASHTranskripten vorhanden ist, wurde eine Northern-Blot-Hybridisierung durchgeführt. Wie Abbildung 14B zeigt, hybridisiert die durch 5'-Marathon-RACE-PCR erhaltene neue $51 \mathrm{Bp}$ cDNA nur mit HASHgerm1.2. Durch Sequenzierung und Sourthern-Blot-Anaylse des genomischen Klons wurde festgestellt, daß diese neue 51 Bp cDNA Information ein neues Exon zwischen Exon 7 und Exon 8 ist und nur zur HASHgerm1.2 gehört.

A

B

\section{$\mathrm{H}-800 \quad 51 \mathrm{Bp}$}

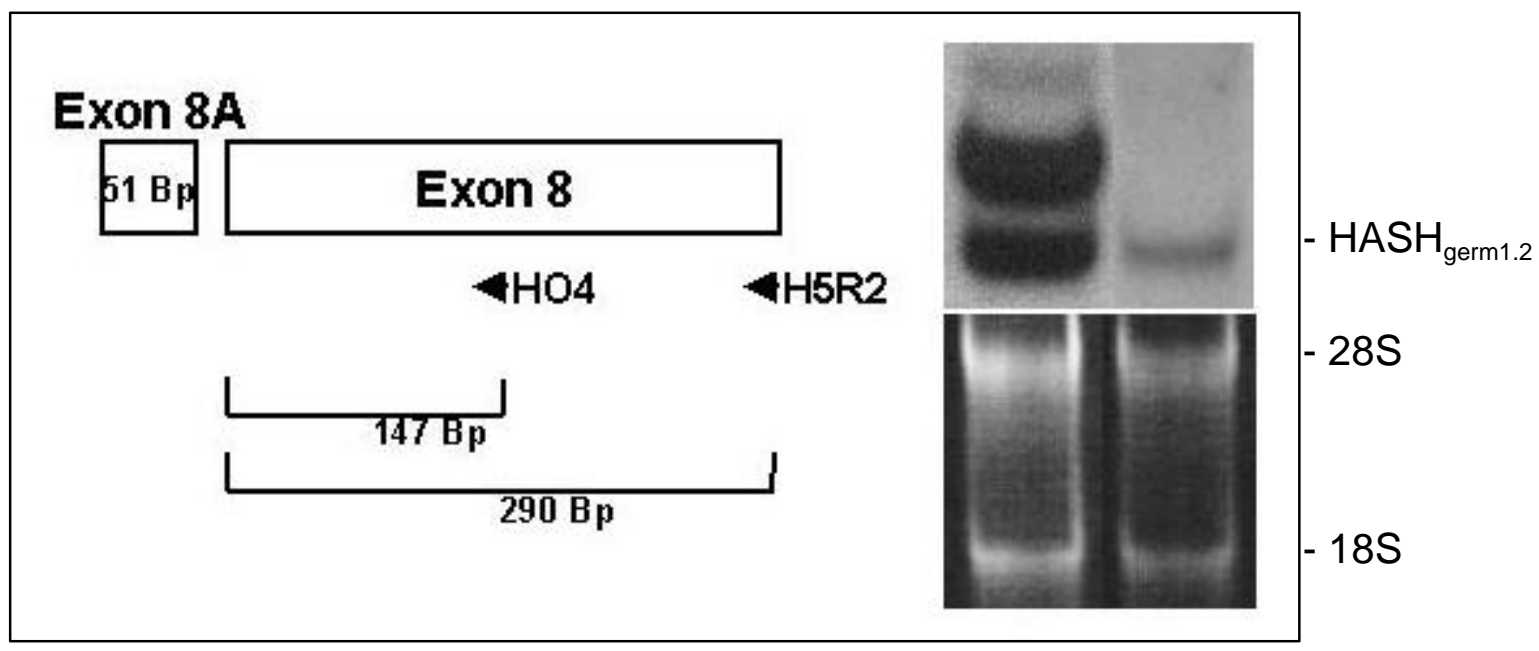

Abb. 14: Neue cDNA Information von 5'-Upstream des Exons 8 und Northern-Blot-Analyse.

A. Schematische Darstellung der durch 5'-Marathon-RACE-PCR erhaltenen neuen cDNA E8A.

B. Gesamt-RNA (je $10 \mu \mathrm{g}$ ) aus Testes der adulten Maus wurde nach denaturierender Gelelektrophorese auf eine Nitrocellulosemembran transferriert und mit der HASH-cDNASonde E8A (51 Bp) hybridisiert. Die Expositionszeit des Autoradiogramms betrug jeweils 24 bis 48 h. Zur Kontrolle der RNA-Proben wurde das Gel mit Ethidiumbromid angefärbt, um die 28S- und 18S-RNAs sichtbar zu machen. 


\section{4. cDNA Struktur der drei HASH-Transkripte}

Aus den in den Abschnitten III.2.2. und 2.3. dargestellten Ergebnissen wurde die cDNA Struktur der drei HASH-Transkripte bestimmt und ist in Abbildung 15 schematisch dargestellt. Das Exon 1 mit einer Länge von 948 Bp wird nur in HASHsoma und das Exon 8A mit einer Länge von 51 Bp nur in HASHgerm1.2 exprimiert. Der Unterschied zwischen den drei HASH-Transkripten beruht im wesentlichen auf dem 5'-Ende, was darauf hinweisen kann, daß jedes HASH-Transkript unter der Expressionsregulation eines eigenen Promoters steht.
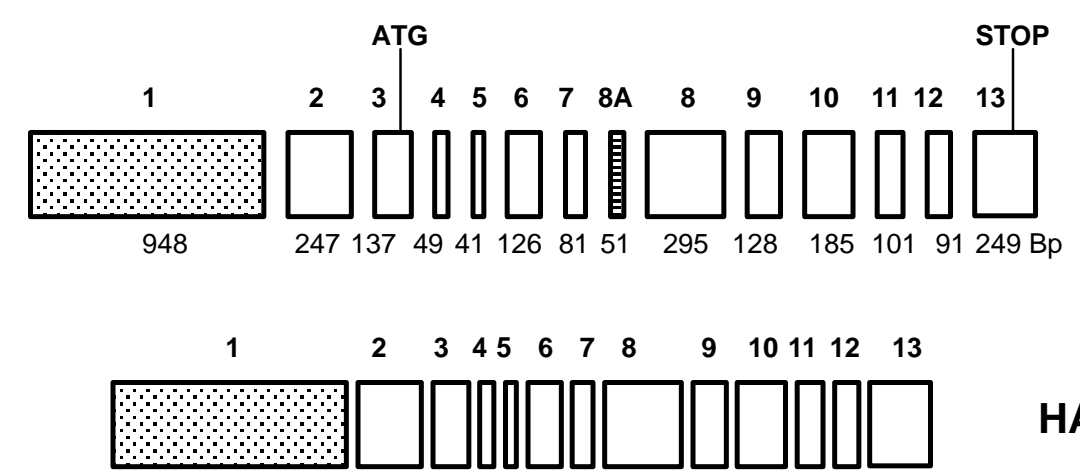

HASHsoma2.6

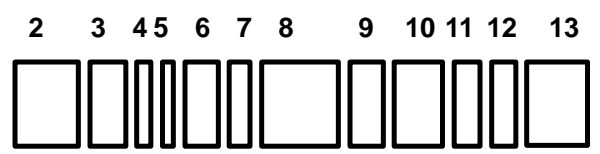

HASHgerm1.8

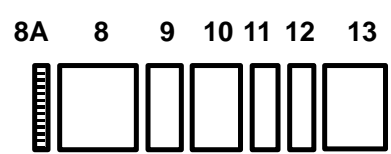

HASHgerm1.2

Abb. 15: Schematische Darstellung der cDNA Struktur der drei HASH-Transkripte. 


\subsection{Nukleotid- und Aminosäuresequenz der HASH-cDNA der Maus}

Unter Einsatz der automatischen Sequenzierung der HASH-cDNA-Klone wurde die gesamte Nukleotidsequenz der drei HASH-Transkripte bestimmt. Mit Hilfe des Computerprogrammes „GCG-Paket“ (Genetics Computer Group, Wisconsin, USA) wurde aus den Sequenzen der cDNA-Klone die gesamte HASH-cDNA-Sequenz erstellt, der offene Leserahmen in der Sequenz ermittelt und die daraus ableitbare Aminosäuresequenz bestimmt (Abb. 16). Die cDNA-Sequenz des $2.6 \mathrm{~Kb}$ HASH-Transkripts hat eine Länge von $2678 \mathrm{Bp}$. Die kodierende Region beginnt an Position 1318 mit dem Initiationsstartkodon ATG (mit Box in Abb. 16 gekennzeichnet), welches sich innerhalb der Konsensus-Sequenz für die Initiation der Translation bei Eukaryoten (Kozak, 1989) befindet. Sie beinhaltet möglicherweise einen offene Leserahmen von 1290 Bp für HASHsoma und HASHgerm1.8 und ein anderen offenen Leserahmen von 789 Bp für HASHgerm1.2. Aber es ist noch unklar, ob die HASHsoma und HASHgerm1.8 dasselbe ATG als Translationsstartpunkt benutzen. Ein anderes ATG-Kodon ist an der Nukleotidposition 1144 (fett in Abb. 16) und ermöglicht einen offenen Leserahmen von 1464 Bp. Der 3'-nichttranslatierte Bereich erstreckt sich über 68 Bp. Der 3'-nichttranslatierte Bereich enthält ein Polyadenylierungssignal AATGAAA, das 18 Bp weit vom Poly(A)-Schwanz entfernt ist.

Der Vergleich der HASH-cDNA- und der daraus abgeleiteten Aminosäure-Sequenz mit den Nukleotid- bzw. Aminosäuresequenz in den Datenbanken EMBL und GenBank ergab keine signifikante Homologien zu bekannten Sequenzen. 


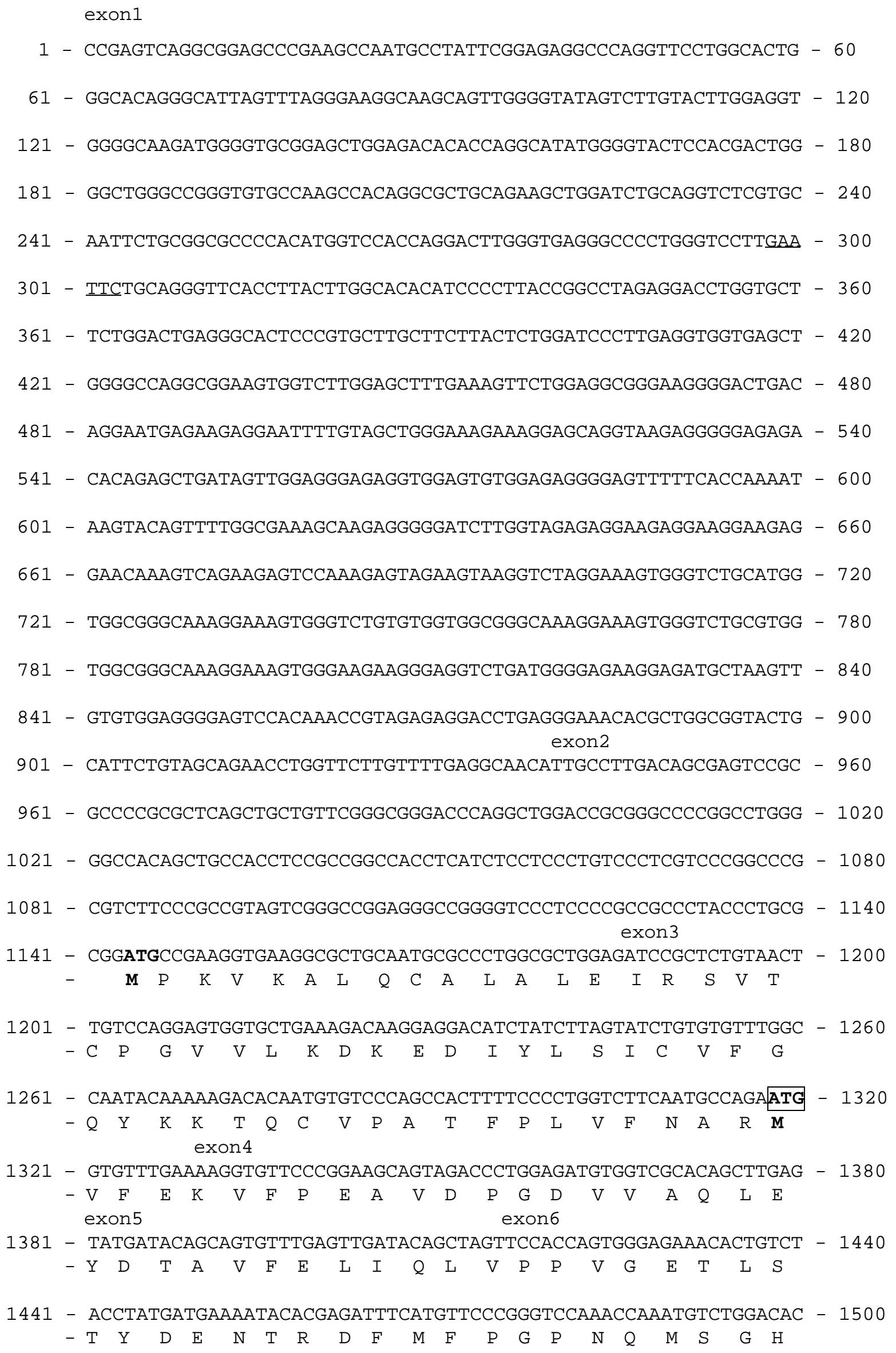




\footnotetext{
exon 7

1501 - CATGATtCAAACCGCCAGGTTACCATGAGGAGGATtTCTGGCCTAAGAGGAATtGCTCCA - 1560

$\begin{array}{lllllllllllllllllllllll}- & H & D & S & N & R & Q & V & T & M & R & R & I & S & G & L & R & G & I & A & P\end{array}$

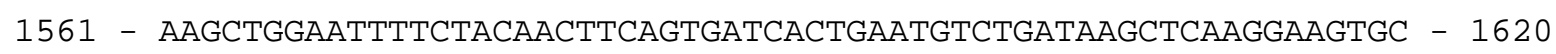

$\begin{array}{llllllllllllllllllllll}- & K & L & E & F & S & T & T & S & V & I & T & E & C & L & I & S & S & R & K & C\end{array}$

1621 - CGCACTCAG

$\begin{array}{lll}-R & T & Q\end{array}$

exon8a

GACCAACGTGGGAGAAGGTCCTGGAGCACACCAAGAAGAAAATGACCTGAT

exon8

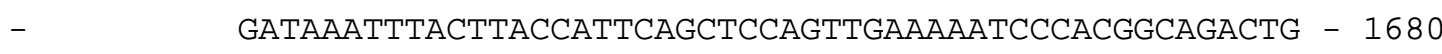

$\begin{array}{llllllllllllllllllll}- & \text { D } & K & F & T & Y & H & \text { S } & \text { A } & \text { P } & \text { V } & \text { E } & \text { K } & \text { S } & \text { H } & \text { G } & \text { R } & \text { L }\end{array}$

1681 - CAATGCAGAACATCAAGATCACAGAAGAAAAAGTCCAAGTCACCCGAGAGGAGTAAATAT - 1740

$\begin{array}{llllllllllllllllllllll}- & Q & C & R & T & S & R & S & Q & K & K & K & S & K & S & P & E & R & S & K & Y\end{array}$

1741 - TGCATAAACACCAAGAACTACGAACAGCCTACGATTTCCTCAAAGTCACACTCTCCATCT - 1800

$\begin{array}{llllllllllllllllllllll}- & C & I & N & T & K & N & Y & E & Q & P & T & I & S & S & K & S & H & S & P & S\end{array}$

1801 - CCCTACACAAAAAGACGGATGTGTGAGCTTTCCGAAGACACTCGGCGGCGGCTGGCCCAT - 1860

$\begin{array}{llllllllllllllllllllll}- & P & Y & T & K & R & R & M & C & E & L & S & E & D & T & R & R & R & L & A & H\end{array}$

1861 - TTAAATCTGGGACCCTATGAATTCAAAAAGGAAACAGATAAGCCTCCATtTGTGATTAGA - 1920

$\begin{array}{lllllllllllllllllll}- & L & N & L & G & P & Y & E & F & K & K & E & T & D & K & P & P & F & V\end{array}$ exon9

1921 - CATGTTGATCCCCCGAGTCCCAGAACTGACAAtTtTtTtGGATCACCTGGCAGAGACTGT - 1980

$\begin{array}{llllllllllllllllllllll}- & H & V & D & P & P & S & P & R & T & D & N & F & F & G & S & P & G & R & D & C\end{array}$

1981 - GAACGAGATGGATGGGTCAGGATGCACAGCGATCATCCTCATATTGGCTGCTGCAGATCC - 2040

$\begin{array}{lllllllllllllllllllll}- & E & R & D & G & W & V & R & M & H & S & D & H & P & H & I & G & C & C & R & S\end{array}$ exon 10

2041 - AAGGACTACAAGGTTATCAGGTCACCACATGGGAGAGACTTTGAGGATCCCTTTGAAAGG - 2100

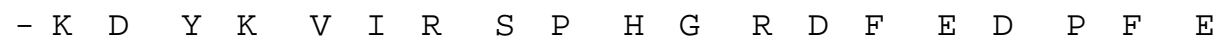

2101 - TGTGAGGAATATTTGAGCCCAAGGACATGTAGCAAGCCCCAGCATTCTGCAAGGACCTTA - 2160

$\begin{array}{llllllllllllllllllllll}- & C & E & E & Y & L & S & P & R & T & C & S & K & P & Q & H & S & A & R & T & L\end{array}$

2161 - CTAGTCCATTCAGCACCTTCAACAACACCAAAGCATtGTGCAAGCCCTGTGCTAAATAGA - 2220

$\begin{array}{lllllllllllllllllllll}- & \text { L } & \text { V } & \text { H } & \text { S } & \text { A } & \text { P } & \text { S } & \text { T } & \text { T } & \text { P } & \text { K } & \text { H } & \text { C } & \text { A } & \text { S } & \text { P } & \text { V } & \text { L } & N\end{array}$ exon11

2221 - GCCTCtCtCAgGGAAAGATtCCACtCtGAtTGGTGTtCACCTCCAAACTGTGATGAGATC - 2280

$\begin{array}{llllllllllllllllllll}- & \text { A } & \text { S } & \text { L } & R & \text { E } & R & \text { F } & \text { H } & \text { S } & \text { D } & \text { W } & \text { C } & \text { S } & \text { P } & \text { P } & \text { N } & \text { C } & \text { D } & \text { E }\end{array}$

2281 - CATGACCGGGTAAAAGATGTCTTGAAATCACATCAAGCTCATGCAAGACATtTATGTGAT - 2340

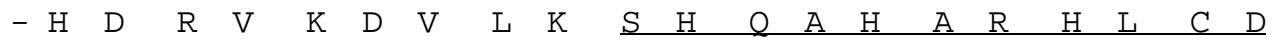

2341 - GAGAGAGACCCAGAGAGAGAAGACGAACTGGAACTGAAAAGAAGTCTTTTATATAGAGAC - 2400

$\begin{array}{lllllllllllllllllllll}- & \underline{E} & R & D & P & E & R & E & D & E & L & E & L & K & R & S & L & L & Y & R & D\end{array}$ exon13

2401 - TCCGCCTATGACAgTGACCCTGAATATAGCTCCTTTCAGCGGCCGCGTGGCTCtTTCCAT - 2460

$\begin{array}{llllllllllllllllllllll}- & S & A & Y & D & S & D & P & E & Y & S & S & F & Q & R & P & R & G & S & F & H\end{array}$

2461 - TTGGATGATGGTGAATGCTGGTCCAACAGAGCAGCCTCTTGTAAAGGGAAATCCCACCGA - 2520

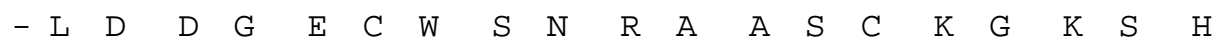




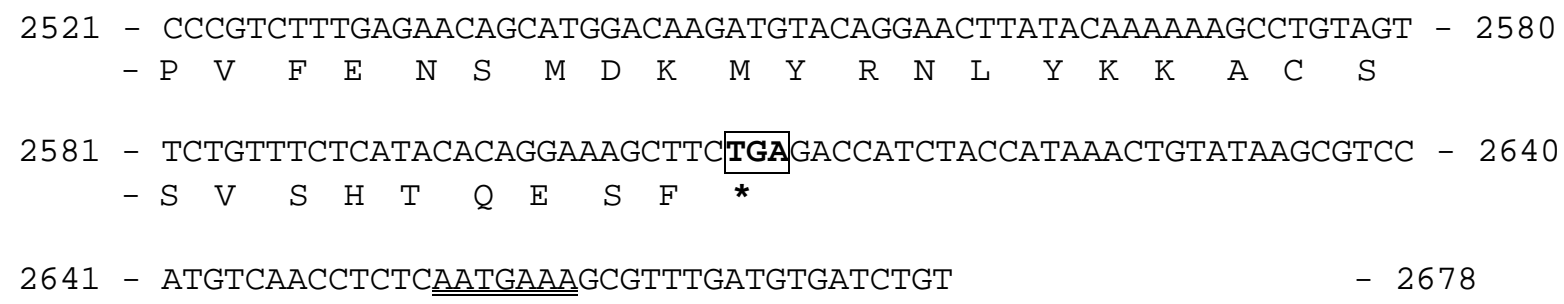

Abb. 16: Nukleotidsequenz der HASH-cDNA und die daraus abgeleitete Aminosäuresequenz für das HASH-Protein der Maus.

Sie besteht aus 2678 Bp und der offene Leserahmen beginnt mit dem der Kozak's KonsensusSequenz entsprechenden Startkodon ATG (mit Box gekennzeichnet) an Nukleotidposition 1318 für HASHsoma und HASHgerm1.8 bzw. an Nukleotidposition 1819 für HASHgerm1.2 und endet mit dem Stopkodon TGA (mit * und Box gekennzeichnet) an Nukleotidposition 2607. Ein anderes ATG-Kodon ist an der Nukleotidposition 1144 (fett) und ermöglicht einen offenen Leserahmen von 1464 Bp. Die Aminosäuresequenz ist im Einbuchstaben-Kode dargestellt. Das Polyadenylierungssignal AATGAAA an Nukleotidposition 2653 ist doppel unterstrichen.

\subsection{Identifizierung des Translationsproduktes der HASH-mRNAs}

In der Nukleotid-Sequenz der HASH-cDNA befinden sich drei ATG-Kodons im selben Leserahmen an den Positionen 1144, 1318 und 1819 (Abb.16). Nur das zweite der drei ATGKodons entspricht der Konsensus-Sequenz für die Initiation der Translation bei Eukaryonten (Kozak, 1984). Aus diesen Befunden entstand in Bezug auf die drei HASH-Transkripte die folgende Frage: Für wieviele Proteine kodiert das HASH-Gen? Welche ATGs werden als Initiationskodons genutzt? Um diese Fragen $\mathrm{zu}$ bearbeiten, wurde ein polyklonaler Antikörper mit einem aus der cDNA abgeleiteten HASH-Peptid (unterstrichen in Abb. 16) hergestellt (s. II.25).

Durch Western-Blot-Analyse wurde das Serum nach der dritten 'Boost'-Immunisierung überprüft. Frisches Gewebe wurde in ein 15 ml Falcon-Gefäß mit 1 Vol. SEM-Puffer gegeben. Das Gewebe wurde mit einem Dispergierwerkzeug (Ultraturrax T25, Schütt, Göttingen) homogenisiert, und die groben Gewebetrümmer wurden abzentrifugiert (4000x g, 10 min, 
$4^{\circ} \mathrm{C}$ ). Der Proteinüberstand wurde nach Zugabe von 1 Vol. 2x SDS-Auftragspuffer zur Denaturierung $10 \mathrm{~min}$ im Wasserbad gekocht und danach auf Eis abgekühlt. $10 \mu \mathrm{l}$ des Überstandes in SDS-Auftragspuffer wurden im 10\%igen SDS-Gel aufgetrennt. Nach eletrophoretischer Auftrennung wurde das gesamte Protein auf eine PVDF-Membran transferriert und mit dem gegen Leber-Proteinextrakt absorbierten Antiserum umgesetzt (Abb. 17).

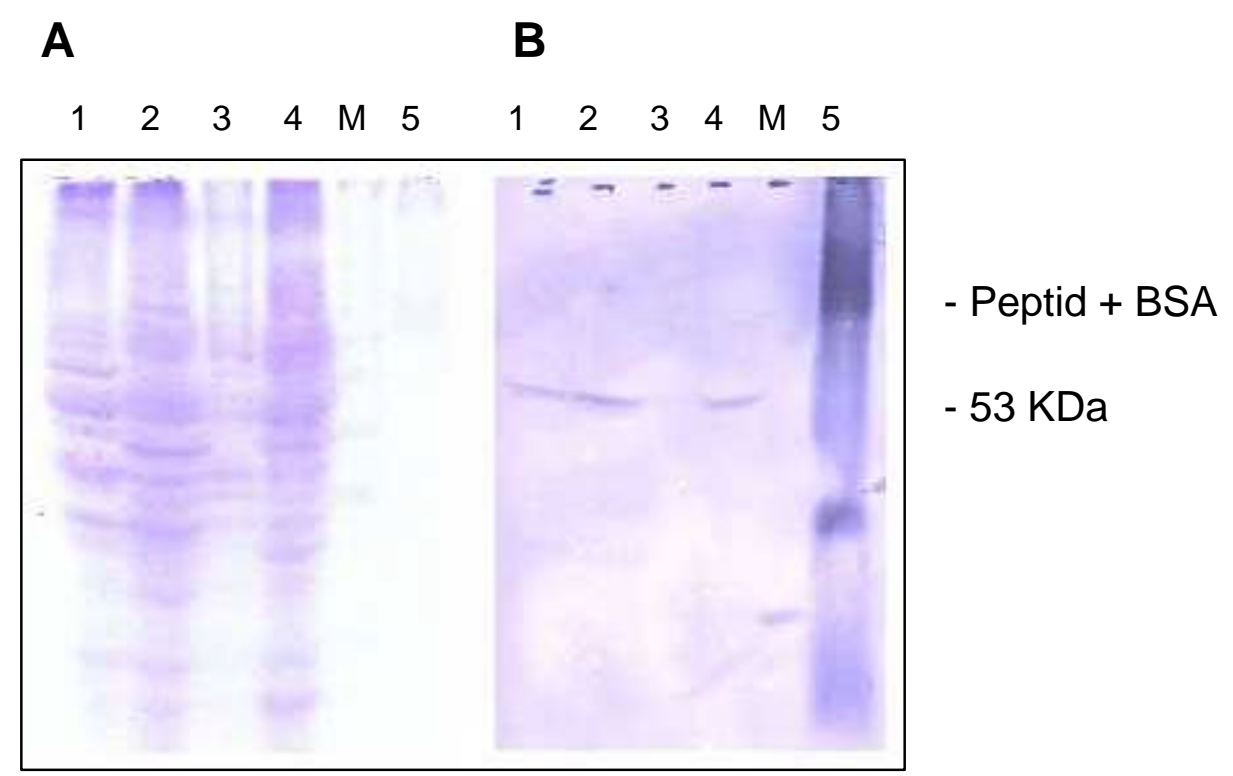

Abb. 17: Western-Blot-Analyse mit dem polyklonalen HASH-Antiserum.

A. Proteinextrakte aus Tymus (1), Gehirn (2), Ovar (3) und Testis (4) wurden im 10\%igen SDSPAGE-Gel elektrophoretisch aufgetrennt. In Bahn 5 ist das mit dem BSA gekoppelte Peptid geladen. $M=10 \mathrm{kDa}$ Protein-Marker (Gibco/BRL).

B. Das Gel (A) wurde auf eine PVDF-Membran geblottet und mit dem gegen Leber-Proteinextrakt adsorbierten Antiserum umgesetzt. In Thymus (1), Gehirn (2) Ovar (3) und Testis (4) wurde eine Bande von etwa 53 KDa detektiert. 
Wie in Abbildung 17 gezeigt, kann in Thymus, Gehirn und Ovar, in denen nur HASHsoma exprimiert ist (s. III.2.1.1), eine Bande von etwa $53 \mathrm{KDa}$ detektiert werden. Überraschenderweise wurde auch in Testisextrakt nur eine $53 \mathrm{KDa}$ große Bande detektiert, obwohl drei HASH-Transkripte in Testis nachweisbar sind (s. III 2.1). Aus diesen Ergebnissen könnte gefolgert werden, daß die Transkripte für HASHgerm1.2 nicht translatiert werden. Es ist noch unklar, ob das andere keimzellspezifisch exprimierte Transkript HASHgerm1.8 zum Protein translatiert wird. Die Berechnung des Molekulargewichtes eines HASH-Proteins unter Berücksichtigung des ersten bzw. des zweiten ATG-Kodons beträgt $56.2 \mathrm{KDa}$ bzw. $49.7 \mathrm{KDa}$. Unter Berücksichtigung einer postranslationalen Modifikation, z.B. durch Phosphorylierung, kann angenommen werden, daß das $53 \mathrm{KDa}$ große HASH-Protein durch das zweite ATG-Kodon, das der KonsensusSequenz für die Initiation der Translation bei Eukaryonten entspricht, entsteht. 


\section{Isolierung und Charakterisierung der genomischen HASH-Klone der Maus}

\subsection{Screenen der Phagen-Bibliothek mit dem cDNA-Fragment für Exon 3 und 4}

In der Dissertation von Aho (1997) wurden 8 genomische HASH-Klone der Ratte isoliert, die insgesamt 12 Exons des HASH-Gens enthalten. Das HASH-Gen der Ratte hat eine Größe von über $100 \mathrm{~Kb}$, und es liegt im Rattengenom als 'single copy'-Gen vor. Für die Isolierung der genomischen Klone für das HASH-Gen der Maus wurde eine Lamda FIX II genomische Bibliothek (Clontech) gescreent. Als Sonde für das Screenen der genomischen Bank diente das durch RT-PCR (723P2F/HA71) generierte partielle cDNA-Fragment E3/4 (Abb. 7), welches das putative Initiationskodon für die Translation des HASH-Proteins enthält. Dieses Screenen mit dem cDNA-Fragment E3/4 wurde in erster Linie durchgeführt, um einen genomischen Klon des HASH-Gens für 'Knock out'-Experimente zu erhalten.

Nach zweimaligem Rescreenen wurde ein Phagenklon isoliert und aufgereinigt. Der Klon wurde mit hgmATG bezeichnet. Das genomische DNA-Insert von hgmATG wurde mit den Enzymen Apa I, Not I, Sst I, Xba I, Xho I, Apa I/ Not I, Apa I/ Sst I, Xho I/ Not I und Xho I/ Sal I verdaut, gelelektrophoretisch aufgetrennt, auf eine Nitrocellulosemembran geblottet und mit der HASH-cDNA-Sonde ATG-E hybridisiert (Abb. 18A, B). Daraus konnte festgestellt werden, daß die Größe des einklonierten genomischen Fragmentes etwa $12.5 \mathrm{~Kb}$ betrug. Das $12.5 \mathrm{~Kb}$ große genomische Fragment des Phagen-Klons wurde mit dem Restriktionsenzym Not I geschnitten, in den pZErO-Vektor (Invitrogen) umkloniert (pZErO-hgmATG) und für die weitere Analyse eingesetzt. 
A B

$\begin{array}{lllllllllllllllllllll}M & 1 & 2 & 3 & 4 & 5 & 6 & 7 & 8 & 9 & 10 & 1 & 2 & 3 & 4 & 5 & 6 & 7 & 8 & 9 & 10\end{array}$

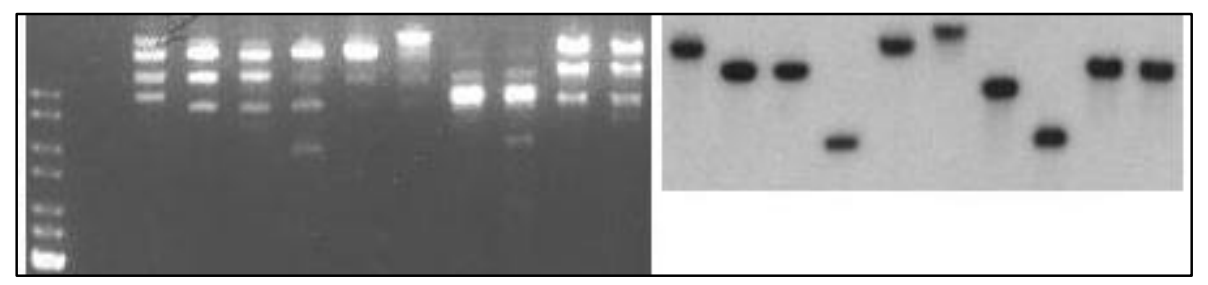

C D

$\begin{array}{lllllllllllllllllll}1 & 2 & 3 & 4 & 5 & 6 & 7 & 8 & 9 & \mathrm{M} & 1 & 2 & 3 & 4 & 5 & 6 & 7 & 8 & 9\end{array}$

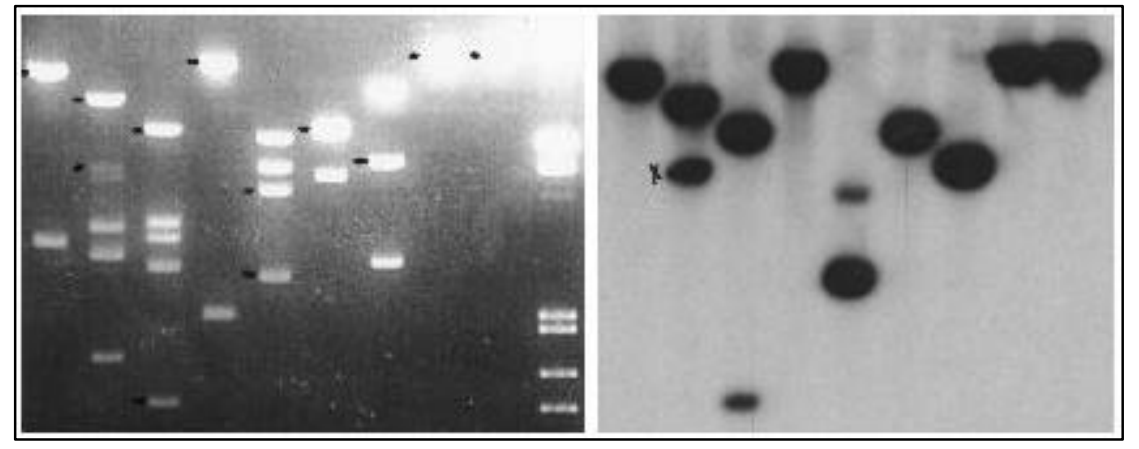

Abb. 18: Hybridisierungen der Restriktionsfragmente des genomischen Phagenklon hgmATG (A, B) und des Plasmidklons pZErO-hgmATG (C, D).

A. Restriktionsenzymatische Spaltung des Phagenklons hgmATG mit den Enzymen Apa I (1), Not I (2), Sst I (3), Xba I (4), Xho I (5), Apa I/ Not I (6), Apa I/ Sst I (7), Xho I/ Not I (8) und Xho I/ Sal I (9).

C. Restriktionsenzymatische Spaltung des Plasmidklons pZErO-hgmATG mit den Enzymen Apa I (1), BamH I (2), Hind III (3), Kpn I (4), Pst I (5), Sst I (6), Spe I (7), Xba I (8) und Xho I (9).

$B$ und D. Hybridisierung mit der partiellen HASH-cDNA-Sonde E3/4 (Abb. 7). Nach der Gelelektrophorese (je A, C) wurde die DNA auf eine Nitrocellulosemembran geblottet und mit der HASH-cDNA-Sonde E3/4 hybridisiert. Die Expositionszeit betrug ca. $2 h(B)$ bzw. $1 h(D)$.

$M=I$ Kb Ladder-DNA (Gibco) in A und LamdaDNA (EcoR I / Hind III) in C als Marker 
Das genomische DNA-Insert von pZErO-hgmATG wurde mit den Enzymen Apa I, BamH I, Hind III, Kpn I, Pst I, Sst I, Spe I, Xba I und Xho I verdaut, gelelektrophoretisch aufgetrennt, auf eine Nitrocellulosemembran geblottet und mit der HASH cDNA-Sonde ATG-E hybridisiert (Abb. 18C, D). Weitere Southern-Blot-Hybridisierungen mit den partiellen HASH-cDNA-Sonden E2 (Abb. 7) bzw. E5/6 (Abb. 7), die die cDNA-Sequenzen von Exon 2 bzw. Exon 5 und 6 des HASH Gens enthalten, zeigten keine Hybridisierung (Daten nicht gezeigt). Damit konnte festgestellt werden, daß das $12.5 \mathrm{~Kb}$ lange, genomische Insert nur Exon 3 und Exon 4 des HASH-Gens enthält.

Um eine noch genauere Restriktionskarte von pZErO-hgmATG zu erhalten, wurde das genomische DNA-Insert mit folgenden Kombinationen von Enzymen doppelverdaut: BamH I/ Apa I, BamH I/ Kpn I, BamH I/ Xho I, Spe I/ Kpn I Spe I/ Xho I, Sst I/ Kpn I, Sst I/ Xho I, Pst I/ Kpn I, Pst I/ Xho I und Xba I/ Xho I (Daten nicht gezeigt). Hierbei hybridisierte ein 3.2 Kb großes Sst I/ Spe I-Fragment. Das 3.2 Kb große Sst I/ Spe I-Fragment wurde isoliert und in den Vektor pZErO (pZ-H-K) umkloniert. Weiterhin wurden ein $6.2 \mathrm{~Kb}$ Sst I-, ein 2.7 Kb Spe I/ Not I- und ein $1 \mathrm{~Kb}$ Not I/ Sst I- Fragment isoliert und jeweils in den Vektor pUC18 (pUC-H-5) und pBluescript (pBS-H-3' und pBSH5P) kloniert. Die Organisation des Plasmidklons pZErO-hgmATG und die Lokalisation aller subklonierten Fragmente sind in Abbildung 19A wiedergegeben. Anschließend wurden die genomischen Klone pZErO-hgmATG und pZ-H-K mit mehreren sequenzspezifischen Primern ansequenziert und mit Hilfe des Computerprogrammes 'GCG-Paket' mit der Nukleotidsequenz der cDNA verglichen. Diese sequenzanalytische Auswertung ergab, daß der Subklon pZErO-K die beiden Exons 3 und 4 des HASH-Gens enthält. Die Position der Exons 3 und 4 im Subklon pZ-H-K wird in Abbildung 19B dargestellt. 


\section{A}
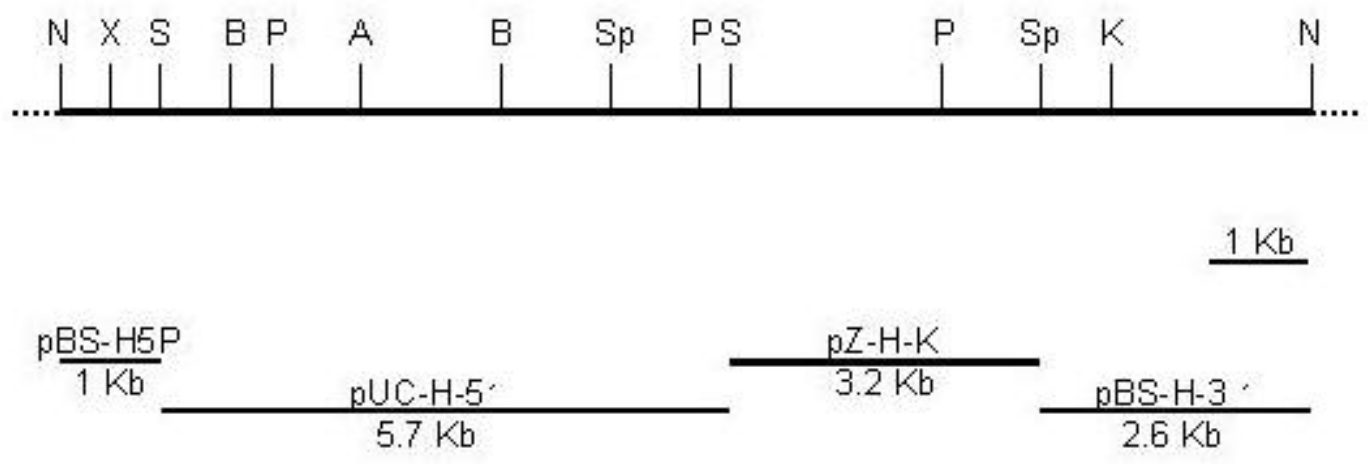

B

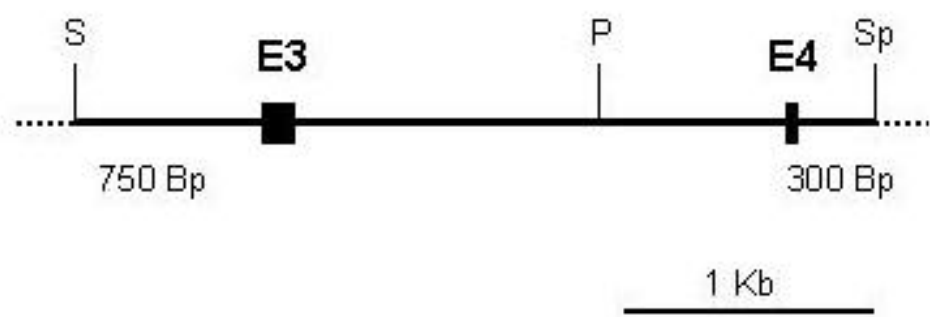

Abb. 19: Restrktionskarte und genomische Organisation des genomischen Klons pZErO-hgmATG und pZErO-K.

A. Die Restriktionskarte des genomischen Klons pZErO-hgmATG. Darunter befindet sich eine Längenangabe der entsprechenden DNA-Fragmente, die für die weitere Analyse subkloniert wurden. Die jeweiligen Subklone sind durch ihre Bezeichnung und Längenangabe der klonierten Fragmente wiedergegeben.

B. Die schematische Darstellung des genomischen Subklons pZErO-K zeigt die genaue Lokalisation der beiden Exons (E3 und E4). 


\subsection{Versuche zur Isolierung der Promotorregionen des HASH-Gens der Maus}

Wie in Abschnitt 3.1. gezeigt, beinhaltet der genomische HASH-Klon hgmATG nur Exon 3 und Exon 4. Die Ergebnisse der RT-PCR und der Northern-Blot-Hybridisierung mit verschiedenen Exon-spezifischen Fragmenten (Abschnitt III.2.2.) weisen darauf hin, daß jedes HASH-Transkript durch einen eigenen Promotor reguliert wird. Daher wurden für das folgende Screenen die HASH-cDNA-Sonden E1, E2 und E8 eingesetzt. Das Screenen der verschiedenen genomischen Banken der Maus (Phagenbank von Clontech, P1- und BACBank des RZPD) mit den cDNA-Sonden E1 und E8 brachte keine Erfolge. Die Sonde E2 ergab eine Reihe unspezifischer Signale, die auf den sehr hohen GC-Gehalt (87\%) in der Sequenz des E2-Fragmentes zurückzuführen sind.

\subsubsection{Screenen der Cosmid-Bibliothek mit Exon 1}

Durch das Screenen einer genomischen Cosmid-Bibliothek der Maus des RZPD (Berlin) mit der HASH-cDNA-Sonde E1 (Abb. 7) wurden zwei Cosmidklone isoliert und jeweils mit Hcos-A, Hcos-B bezeichnet. Um einen spezifischen Klon zu erhalten, wurden die Klone Hcos-A und -B auf LB-Agarplatten mit Kanamycin $(50 \mu \mathrm{g} / \mathrm{ml})$ wieder ausplattiert. Aus je 6 Kolonien wurde die genomische DNA isoliert, mit dem Enzym EcoR I verdaut und gelektrophoretisch aufgetrennt. Es zeigte sich, daß die Restriktionsmuster für alle Kolonien für Hcos-A bzw. für Hcos-B identisch waren. Die beiden Cosmidklone unterscheiden sich lediglich in einem Fragment: ein $1.4 \mathrm{~Kb}$-Fragment im Klon Hcos-A und ein $4 \mathrm{~Kb}-$ Fragment im Klon Hcos-B (Abb. 20A).

Nach der gelelektrophoretischen Auftrennung aller Fragmente wurden diese auf eine Membran transferriert und mit der HASH-cDNA-Sonde E1 hybridisiert (Abb. 20B). Hierbei hybridisierten ein 1.4 Kb großes EcoR I-Fragment aus Hcos-A und ein 4 Kb großes EcoR IFragment aus Hcos-B. Diese Restriktionsanalyse wies darauf hin, daß das Exon 1 enthaltende EcoR I- Fragment am 5'- oder 3'-Ende des klonierten Inserts lokalisiert ist. Zudem betrug die Größe der einklonierten genomischen Fragmente ca. 33 Kb bzw. 36 Kb. Deshalb wurde im folgenden lediglich der Cosmidklon Hcos-B für weitergehende Untersuchungen berücksichtigt. In der weiteren Southern-Blot-Analyse mit der durch RACE- 
PCR erhaltenen cDNA-Sonde E1A (Abb. 11) wurde ein $5.5 \mathrm{~Kb}$ großes EcoR I-Fragment hybridisiert (Abb. 20C, D). Tatsächlich wurde durch die Ansequenzierung eine Schnittstelle für EcoR I im Exon 1 gefunden. Dieses $5.5 \mathrm{~Kb}$ EcoR I-Fragment sollte eine putative Promotorregion für HASHsoma enthalten.

A B

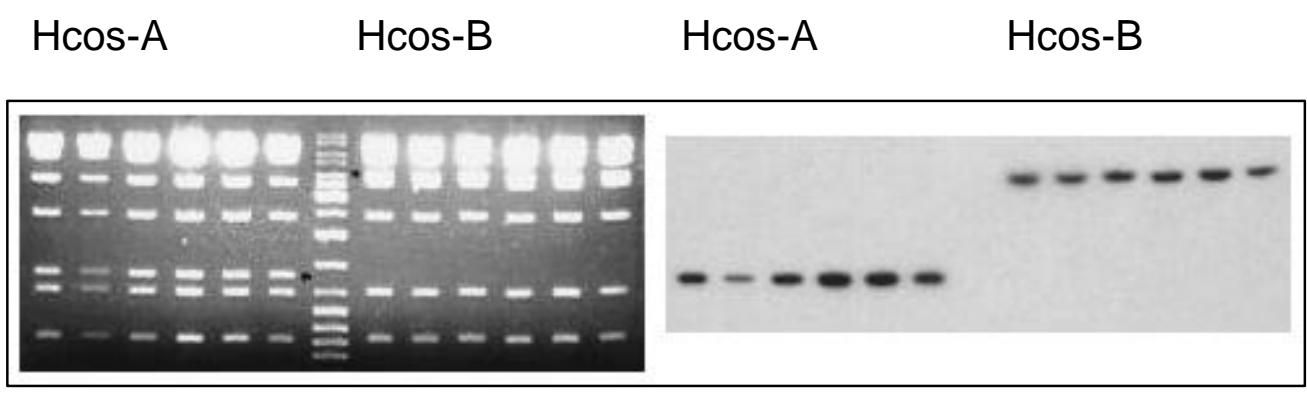

C D

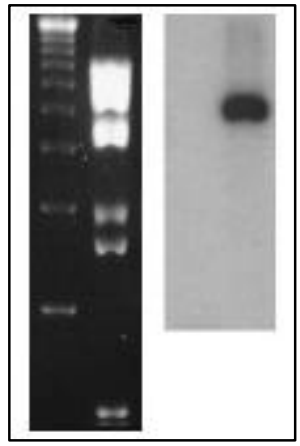

Abb. 20: Hybridisierung der Restriktionsfragmente der genomischen Cosmidklone Hcos-A und -B.

A. Restriktionsenzymatische Spaltung der Cosmidklone Hcos-A und -B mit dem Enzym EcoR I.

B. Hybridisierung mit der partiellen HASH cDNA-Sonde E1 (Abb. 7). Die Expositionszeit betrug ca. $1 h$.

$M=$ Marker $-D N A$ (Gibco)

C. Enzymatischer Verdau des Cosmidklons Hcos-B mit EcoR I.

$D$. Nach der Gelelektrophorese $(C)$ wurde die DNA auf eine Nitrocellulosemembran geblottet und mit der HASH cDNA-Sonde E1A (Abb. 11) hybridisiert. Die Expositionszeit betrug ca. $2 h$. 


\subsubsection{Screenen der Cosmid-Bibliothek mit dem cDNA-Fragment E8}

Durch das Screenen einer genomischen Cosmid-Bibliothek der Maus des RZPD (Berlin) mit der HASH-cDNA-Sonde E8 (Abb. 7) wurde ein Cosmidklon isoliert und mit Hcos-D bezeichnet. Um einen spezifischen Klon zu erhalten, wurde der Klon Hcos-D auf LBAgarplatten mit Kanamycin $(50 \mu \mathrm{g} / \mathrm{ml})$ wieder ausplattiert. Aus 6 Kolonien wurde die genomische DNA isoliert, mit dem Enzym EcoR I verdaut und gelektrophoretisch aufgetrennt. Es zeigte sich, daß das Restriktionsmuster bei allen Kolonien identisch war.

Die DNA des Cosmidklons wurde mit den Enzymen BamH I, EcoR I, EcoR V und Xho I verdaut, gelelektrophoretisch aufgetrennt, auf eine Membran transferriert und mit der HASH-cDNA-Sonde E8 hybridisiert (Abb. 21A, B). Hierbei hybridisierte ein $3.4 \mathrm{~Kb}$ großes EcoR I-Fragment. Die Größe des einklonierten genomischen Fragmentes wurde mit ca. $35 \mathrm{~Kb}$ bestimmt. In der weiteren Southern-Blot-Analyse mit der durch RACEPCR erhaltenen 51Bp langen cDNA-Sonde E8A (Abb. 14) wurde ein $1.4 \mathrm{~Kb}$ großes EcoR IFragment hybridisiert (Abb. 21C, D). Weitere Southern-Blot-Hybridisierungen mit der partiellen HASH-cDNA-Sonde E6/7 (Abb. 7) und der E9 (Abb. 7) zeigten keine Hybridisierung (Daten nicht gezeigt). Daraus konnte festgestellt werden, daß das ca. $35 \mathrm{~Kb}$ lange genomische Insert nur Exon 8A und Exon 8 des HASH-Gens enthält. 


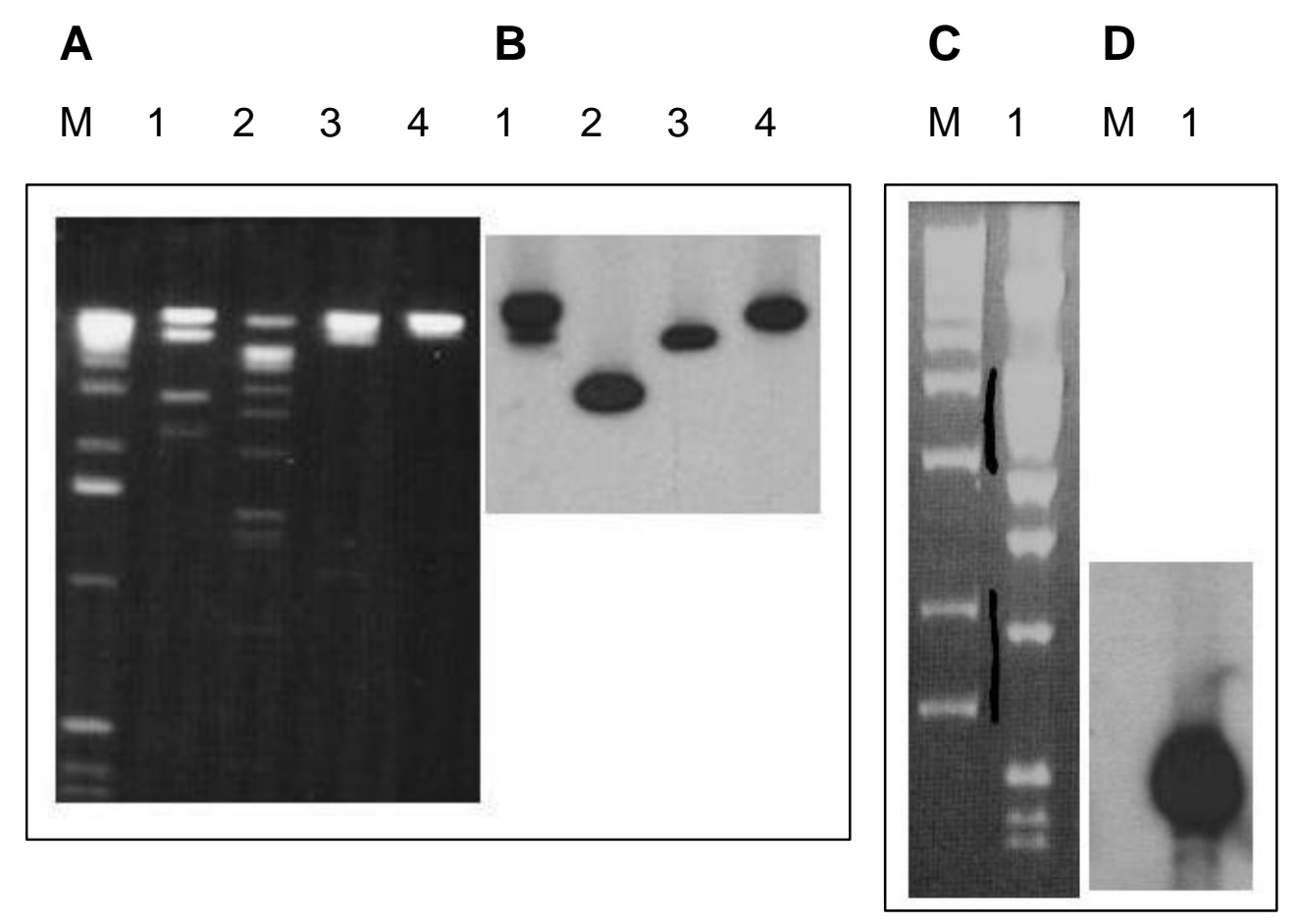

Abb. 21: Southern-Blot-Analyse des genomischen Cosmidklons Hcos-D.
A. Restriktionsenzymatische Spaltung des Cosmidklons Hcos-D mit den Enzymen BamH I (1), EcoR I (2), EcoR V (3) und Xho I (4).

B. Hybridisierung mit der partiellen HASH-cDNA-Sonde E8 (Abb. 7). Die Expositionszeit betrug ca. $2 h$.

C. Enyzmatischer Verdau des Cosmidklons Hcos-D mit EcoR I (Bahn 1).

$D$. Nach der Gelelektrophorese (C) wurde die DNA auf eine Nitrocellulosemembran geblottet und mit der HASH-cDNA-Sonde E8A (Abb. 14) hybridisiert. Die Expositionszeit betrug ca. $1 \mathrm{~h}$. $M=1 \mathrm{~Kb}$ Ladder DNA-Marker (Gibco) 


\subsection{Isolierung eines genomischen HASH Klons aus einer RZPD-Human-P1- Bibliothek}

In der Dissertation von Aho (1997) wurde durch Zoo-Blot-Hybridisierung bestätigt, daß das HASH-Gen bei Säugern hochkonserviert ist. Der Vergleich der HASH-cDNA-Sequenz der Maus mit humanen EST-Klonen (AI240133, AA769927, AI139608 und AA758994) ergab eine ca. 88\% Homologie. Um das HASH-Gen des Menschen zu isolieren, wurde eine Human-P1-Bibliothek mit der cDNA-Sonde H-800 (Abb. 7) der Maus unter niedrig stringenten Bedingungen $\left(60^{\circ} \mathrm{C}\right)$ gescreent. Dabei wurde ein P1-Klon isoliert und mit $\mathrm{hH} 1$ bezeichnet. Die DNA des P1-Klons wurde ohne Verdau auf das Gel aufgetragen, auf eine Nitrocelluosemembran geblottet und mit der HASH-cDNA-Sonde H-800 nochmals hybridisiert (Abb. 22).

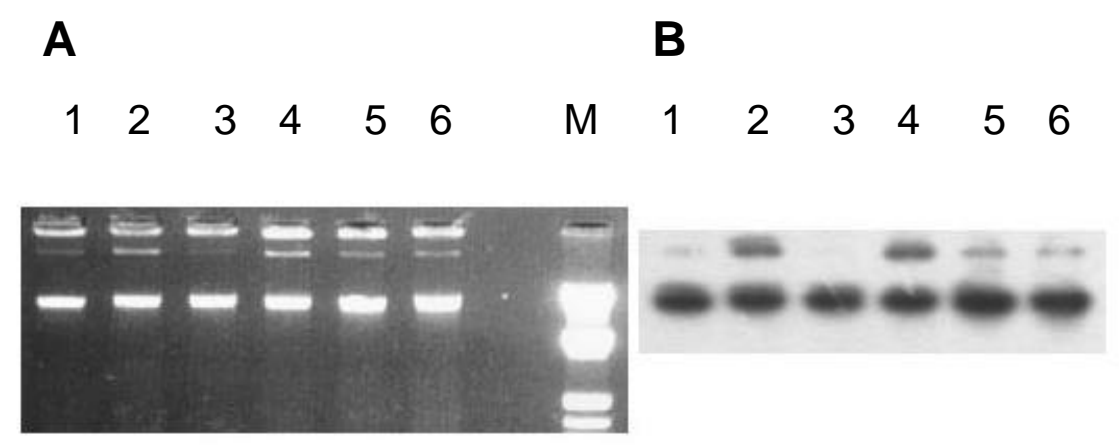

Abb. 22: Hybridisierung des humanen genomischen P1-Klons hH1.

A. Die DNA des hH1-Klons aus 6 verschiedenen Kolonien wurde ohne Verdau auf ein $0.8 \%$ iges Agarosegel aufgetragen.

B. Hybridisierung mit der partiellen HASH cDNA-Sonde H-800 (Abb. 7) der Maus. $M=$ LamdaDNA (EcoR I/ Hind III) als Marker 


\subsection{Chromosomale Lokalisation des HASH-Gens des Menschen}

In der Dissertation von Aho (1997) wurde die chromosomale Lokalisation des HASH-Gens der Ratte identifiziert. Fluoreszenz-in situ-Hybridisierung (FISH) auf Metaphasenchromosomen der Ratte mit einem 7 Kb genomischen HASH-Fragment ergab, daß das HASH-Gen auf Chromosom 5 der Ratte in der Region q34-q35 lokalisiert ist. Einige bekannte Gene auf Chromosom 5 der Ratte wurden auf Chromosom 4 der Maus und Chromosom 1 des Menschen lokalisiert. Um diese chromosomale Lokalisation des HASH-Gens des Menschen zu bestätigen, wurde die FISH mit dem menschlichen HASH-P1Klon hH1 an Metaphasenchromosomen des Menschen durchgeführt (Abb. 23). Die Kartierung zeigt, daß das HASH-Gen tatsächlich auf dem Chromosom 1 (Region p32-35) lokalisiert ist (Abb. 23).

\section{A}

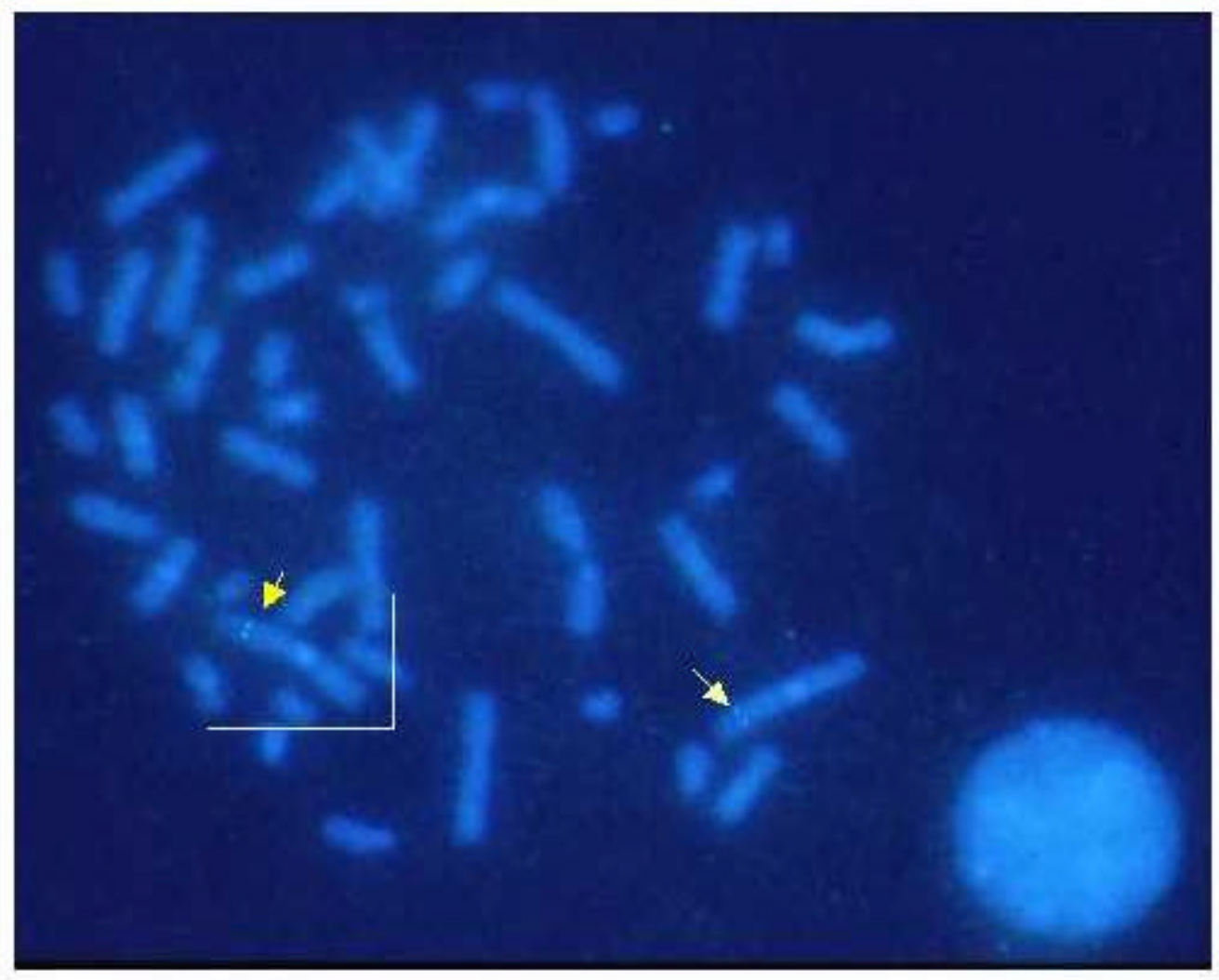


B
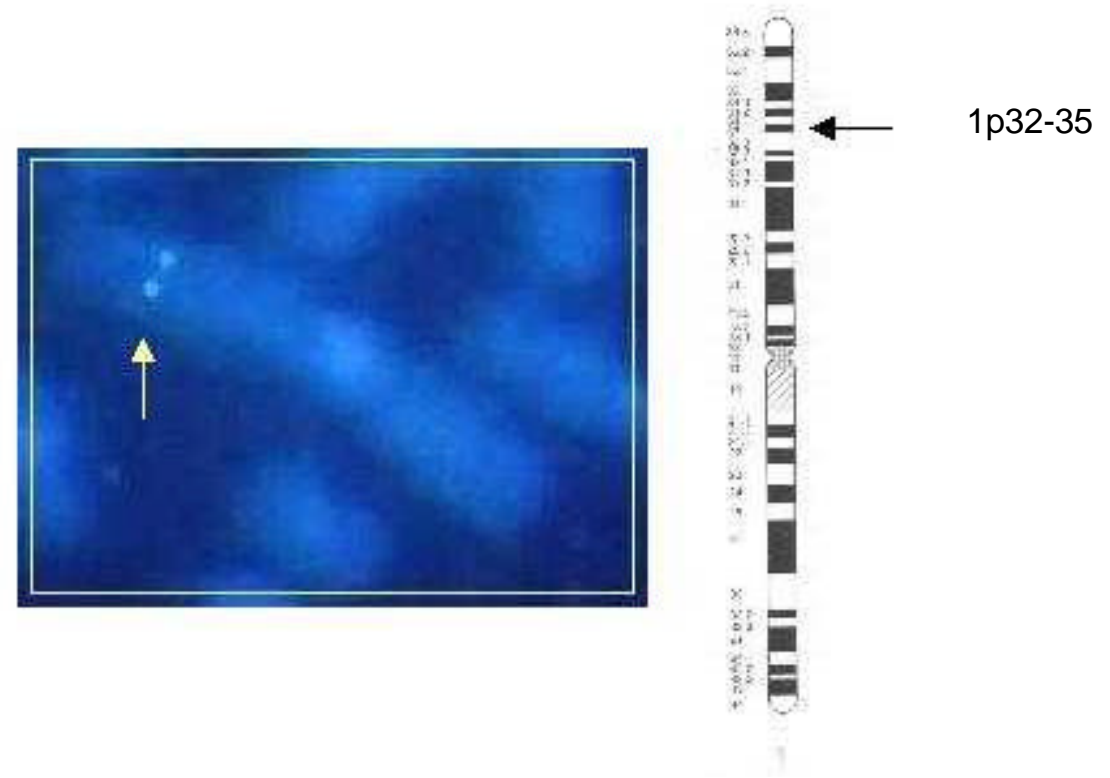

Abb. 23: Chromosomale Lokalisation des HASH-Gens des Menschen.

A. Die Fluoreszenz-in situ-Hybridisierung wurde an Metaphasenchromosomen des Menschen durchgeführt. Als Sonde diente der menschliche HASH-P1-Klon hH1, der mit Hilfe des HASHcDNA-Fragments $\mathrm{H}-800$ (Abb. 7) der Maus isoliert wurde. Die Hybridisierungssignale sind mit Pfeilen gekennzeichnet.

B. Die Box in Bild $A$ ist in größerem Maßstab wiedergegeben. Rechts ist das menschliche Chromosom 1 dargestellt. Das HASH-Gen des Menschen lokalisiert in der Region p32-35 des Chromosoms 1. 


\section{Herstellung HASH-defizienter Mäuse}

Das Hauptziel dieser Arbeit war es, die Funktion des HASH-Gens der Maus zu identifizieren. $\mathrm{Zu}$ diesem Zweck sollte das Gen durch die Methode der homologen Rekombination in embryonalen Stammzellen inaktiviert werden. Für die homologe Rekombination in embryonalen Stamm (ES)-Zellen der Maus werden flankierende, genomische Fragmente einer Größe von 2-5 Kb benötigt. Durch die Verwendung isogener, d.h. aus dem selben Mausstamm stammender DNA, wird die Rekombinationsfrequenz erheblich gesteigert (Melton, 1994). Aus diesem Grund wurde der genomische Phagenklon hgmATG, der ca. 12.5 Kb des HASH-Gens enthält, aus einer 129er genomischen Bibliothek isoliert (s. II.16.). Die homologe Rekombination wurde in RI-ES-Zellen durchgeführt, die ihrerseits aus Blastocysten des Mausstammes 129/SvJ isoliert worden sind.

\subsection{Die Strategie zur Deletion des HASH-Gens der Maus}

Zum Zweck der Konstruktion des Targeting-Vektors und der Subklonierung geeigneter 5'und 3'-flankierender Fragmente wurde im Vorfeld eine detaillierte Restriktionskarte der entsprechenden Subklone pUC-H-5' und pBS-H-3' (Abb. 19) angefertigt. Durch Sequenzund Hybridisierungsexperimente zeigte sich, daß der Phagenklon hgmATG neben der $3.2 \mathrm{~Kb}$ großen Kernregion die beiden Exons E3 und E4 enthält, auch 6.7 Kb der 5'- und 2.7 Kb der 3'-flankierende Sequenz (Abb. 24). Im Exon 3 befindet sich ein ATG-Kodon als Translationsstartpunkt, das der Kozak's Consensus-Sequenz entspricht. Die Deletion des HASH-Gens sollte den dieses ATG-Kodon enthaltenden Bereich betreffen, so daß sichergestellt ist, daß nach erfolgter Rekombination kein funktionelles HASH-Protein mehr entsteht. Die Inaktivierung in embryonalen Stammzellen sollte mit Hilfe eines TargetingVektors vom Replacement-Typ erfolgen, d.h. endogene Sequenzen im nativen Allel werden gegen speziesfremde DNA-Segmente durch 'crossing over' in homologen Sequenzen ausgetauscht. Hierbei handelt es sich um die PGK-Neomycin-Kassette mit einer Größe von ca. 1.8 Kb, die für die positive Selektion der rekombinierten ES-Zellen essentiell ist. Die isolierten 5'- und 3'-flankierenden Segmente sollten in richtiger Anordnung in die 
entsprechenden Klonierungsstellen des pPNT-Vektors (Tybulewicz, et al., 1991) eingefügt werden und die richtige Orientierung durch nachfolgende Restriktionsanalysen überprüft werden. Dadurch können die Rekombinationsereignisse in ES-Zellen aufgezeigt werden. Die vorgesehene Strategie für die Inaktivierung des HASH-Gens der Maus ist in Abbildung 24 dargestellt.
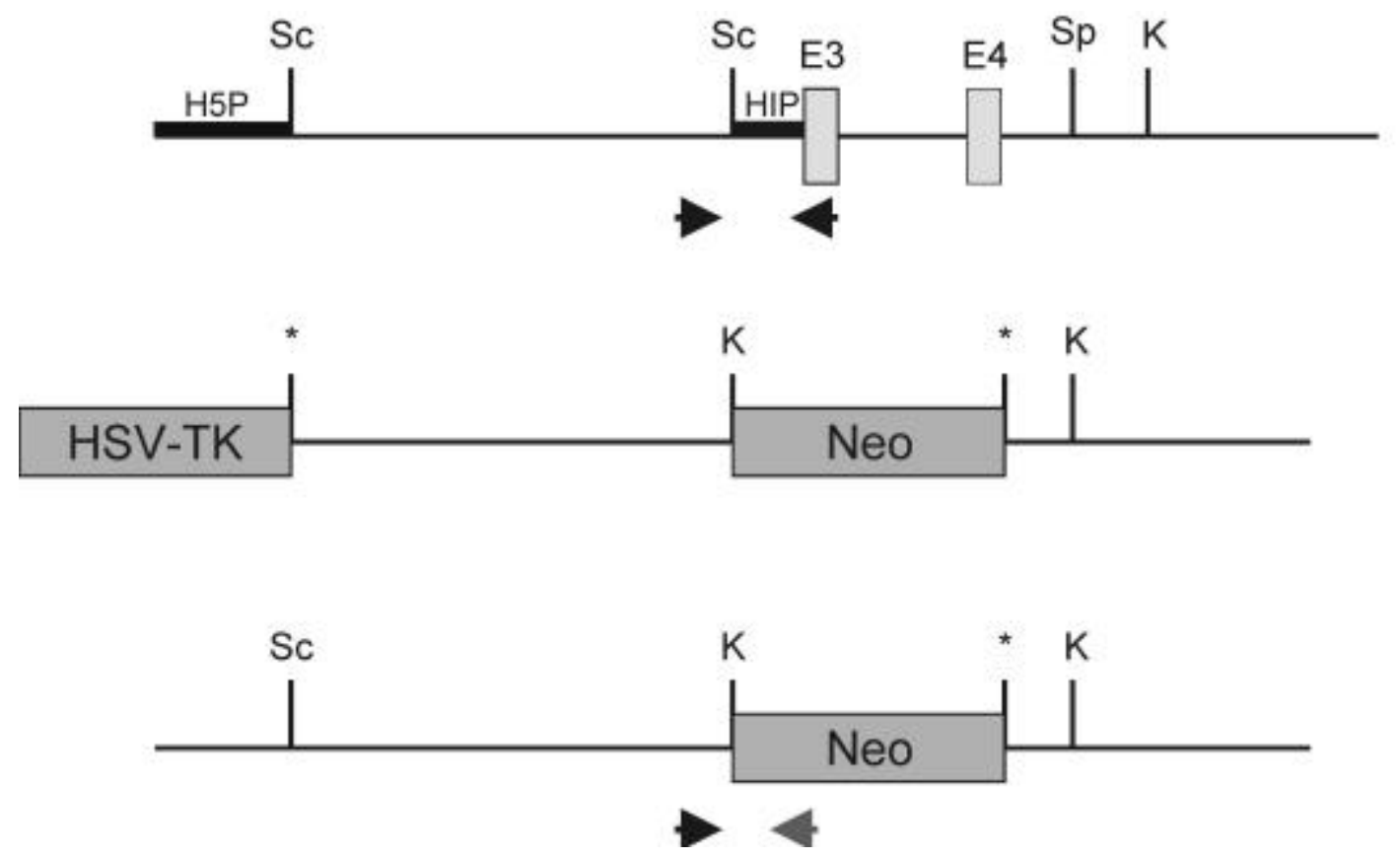

Abb. 24: Strategie zur Deletion des HASH-Gens der Maus.

Die schematische Darstellung zeigt den Vorgang der homologen Rekombination zur Deletion des HASH-Gens. Im oberen Teil findet sich das Wildtyp-Allel mit Exon 3 und Exon 4. In der Mitte ist der Targeting-Vektor dargestellt. Im unteren Teil ist das rekombinierte Allel mit der PGKNeomycin-Kassette zwischen den Sst I- und Spe I-Schnittstellen abgebildet.

HSV-TK: Thymidinkinase Kassette von Herpes Simpex Virus

Neo: Neomycin-Kassette 


\subsection{Isolierung und Klonierung des $5^{\prime}$-flankierenden Fragments}

Für die Klonierung des 5'-flankierenden Bereichs des Targeting-Vektors wurde das gesamte $5.7 \mathrm{~Kb}$ große Sst I-Fragment des Plasmids pZErO-hgmATG in dem Plasmidvektor pUC18 umkloniert (pUC-H-5'; s. Abb. 19). Aus dem Subklon pUC-H-5' wurde die 5'flankierende Region mit dem Restriktionsenzym Xba I herausgeschnitten und über ein 0.8\%iges Agarosegel isoliert. Für die Klonierung dieses 5'-Xba I-Fragments wurde der Plasmidvektor pPNT auch mit dem Enzym Xba I verdaut und mit dem 5'-flankierenden Fragment ligiert. Nach der Transformation des Ligationsansatzes wurden die Kolonien mit der gesamten 2.7 Kb Not I/ Xho I-Sonde des Subklons pBS-H-3' gescreeent. Die PlasmidDNA positiver Klone wurden isoliert und mit dem Enzym Kpn I verdaut und gelelektrophoretisch aufgetrennt. Dabei sollte die richtige Orientierung des 5'-Fragments verifiziert werden. Die richtige Orientierung des 5'-Bereichs im pPNT-Vektor zeigte sich durch die Anwesenheit einer $8 \mathrm{~Kb}$ und einer $5 \mathrm{~Kb}$ großen Bande (pPNT-H-5; Bahn 5 und 6 in Abb. 25). Ein falsch orientiertes Fragment ergab eine $11.5 \mathrm{~Kb}$ und eine $1.5 \mathrm{~Kb}$ große Bande im Agarosegel (Bahn 2 in Abb. 25).

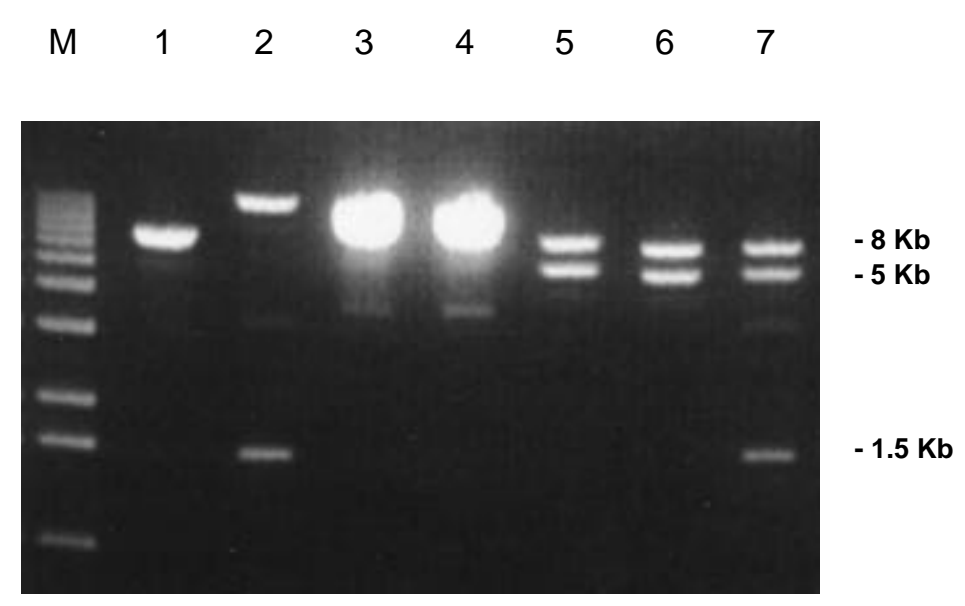


Abb. 25: Restriktionsenzymatischer Nachweis der Orientierung des 5'-flankierenden Fragments im pPNT-Vektor.

Nach gelelektrophoretischer Auftrennung von Kpn I verdauter DNA positiver Klone zeigte sich die richtige Orientierung des $5.7 \mathrm{~Kb}$ großen $5^{\prime}$-flankierenden Fragments durch eine $8 \mathrm{~Kb}$ und eine 5 $K b$ große Bande im Gel (Bahn 5 und 6). Die falsche Anordnung wurde ersichtlich durch eine 11.5 $\mathrm{Kb}$ und $1.5 \mathrm{~Kb}$ große Bande (Bahn 2). In Bahn 7 ist ein Klon mit Doppelintegration des 5'flankierenden Fragments in umgekehrten Richtung zu sehen.

$M=I K b$ DNA-Ladder (Gibco/BRL)

\subsection{Isolierung und Klonierung des $3^{\prime}$-flankierenden Fragments}

Für die Klonierung des 3'-flankierenden Bereichs des Targeting-Vektors wurde das gesamte 2.7 $\mathrm{Kb}$ große Spe I/ Not I-Fragment des Plasmidklons pZErO-hgmATG in einen Plasmidvektor pBluescript umkloniert (pBS-H-3'; s. Abb. 19). Aus dem Subklon pBS-H-3' wurde das 3'-flankierende Fragment mit den Restriktionsenzymen Not I/ Xho I wieder herausgeschnitten und über ein 0.8\%iges Agarosegel extrahiert. Für die Klonierung dieses 3'Fragments wurde der Plasmidvektor pPNT-H-5' ebenfalls mit den Enzymen Not I/ Xho I verdaut und mit dem 3'-flankierenden Not I/ Xho I-Fragment ligiert. Nach der Transformation des Ligationsansatzes wurden die Kolonien mit der gesamten $2.7 \mathrm{~Kb}$ Not I/ Xho I-Sonde des Subklon pBS-H-3' gescreeent. Die Plasmid-DNA positiver Klone wurde isoliert und mit dem Enzym Kpn I verdaut und gelelektrophoretisch aufgetrennt. Der richtige Klon pPNT- $\triangle$ HASH beim Verdau mit dem Enzym Kpn I zeigte sich durch die Anwesenheit einer $8.3 \mathrm{~Kb}, 5 \mathrm{~Kb}$ und $2.4 \mathrm{~Kb}$ großen Bande (Abb. 26). 


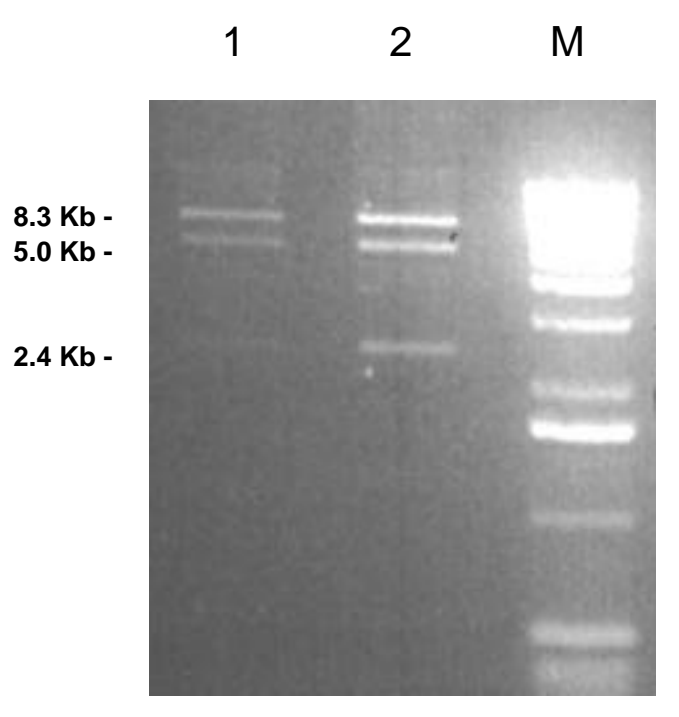

Abb. 26: Restriktionsenzymatischer Nachweis der Umklonierung des $3^{\prime}$-flankierenden Fragments im pPNT-H-5'.

Nach gelelektrophoretischer Auftrennung von Kpn I verdauter DNA positiver Klone zeigte sich die richtige Orientierung des 2.7 Kb großen 3'-flankierenden Fragments durch eine 8.3 Kb, 5 Kb und $2.4 \mathrm{~Kb}$ große Bande im Gel (Bahn 1 und 2).

$M=1 \mathrm{~Kb} D N A-L a d d e r(G i b c o / B R L)$.

Nach Insertion der 5'- und 3'-flankierenden Regionen des HASH-Gens der Maus in den Transfer-Vektor pPNT wurden die Orientierung und die Vollständigkeit der genomischen Fragmente durch den Verdau mit verschiedenen Restriktionsenzymen verifiziert. Dabei zeigten sich keine Abweichungen von den theoretischen Anforderungen an das 'Knockout'Konstrukt (Daten nicht gezeigt). Zudem wurde durch enzymatischen Verdau festgestellt, daß sich der Targeting-Vektor pPNT- $\Delta$ HASH mit dem Enzym Not I linearisieren läßt (Daten nicht gezeigt). 


\subsection{Isolierung und Klonierung der externen $5^{\prime}$-Sonde}

Für die Analyse korrekter Rekombinationsereignisse in den ES-Zellen war die Isolierung einer außerhalb des Konstrukts gelegenen Sonde notwendig. Deshalb wurde das Not I/Sst IFragment $(1 \mathrm{~Kb})$ des Phagenklons hgmATG herausgeschnitten, über ein 1\%iges Agarosegel elektrophoretisch aufgetrennt, aus dem Gel isoliert und dann in den Plasmidvektor pBluescript umkloniert (pBS-H5P). Diese 5'-Sonde H5P (Abb. 24) zeigte nach Hybridisierung mit genomischer DNA der Maus keine repetitiven Sequezen und wurde für die Southern-Blot-Analyse transfizierter ES-Zellen eingesetzt.

\subsection{Analyse der selektierten ES-Zellen nach Elektroporation}

Die RI-ES-Zellen wurden auf einem konfluenten 'Layer' von kultivierten, mit Mitomycin C behandelten primären embryonalen Fibroblasten (EmFi) ausplattiert. Exponentiell wachsende ES-Zellen der Passage 12 wurden auf einer $90 \mathrm{~mm}$ Kulturschale (Nunc) bis zu einer Zahl von 7 x $10^{6}$ Zellen kultiviert, durch Trypsinisierung geerntet und mit $40 \mu \mathrm{g}$ des durch Not I-Verdau linearisierten Targeting-Vektors pPNT- $\Delta$ HASH elektroporiert. Die Zellen wurden nach dem DNA-Transfer für $20 \mathrm{~min}$ auf Eis inkubiert und anschließend in fünf 60 mm Kulturschalen mit EmFi-Zellen ausplattiert. Die Selektion in G418 (Positiv-Selektion) und Gancyclovir (Negativ-Selektion) begann nach 12 bis 16 h. Die Gancyclovir-Selektion wurde nach 5 Tagen beendet, während die G418-Selektion bis zur Isolierung resistenter Klone am Tag 8-9 aufrechterhalten wurde.

Nach Selektion wurden insgesamt 72 positive Klone isoliert. Zunächst wurde die Hälfte der Zellen jedes Klons bei $-80^{\circ} \mathrm{C}$ kryokonserviert, während die zweite Hälfte der Zellen bis zur Konfluenz kultiviert und für die Genotypisierung herangezogen wurde. Die isolierte DNA aller ES-Zellklone wurde mit dem Enzym Kpn I verdaut und nach einer gelelektrophoretischen Auftrennung einer Southern-Blot-Analyse mit der externen 5'-Sonde unterzogen. Hierbei sollte das endogene Allel des HASH-Gens der Maus durch eine ca. 17 $\mathrm{Kb}$ Bande charakterisiert werden, während das mutierte Allel durch die Insertion der Kpn ISchnittstelle im 3'-Ende der Neomycin-Kassette ein Fragment von ca. 14 Kb ergibt (Abb. 
27A). Um die richtige Integration und homologe Rekombination zu überprüfen, wurde die DNA aus den ES-Zellen auch mit der internen Neomycin-Sonde hybridisiert. Hierbei sollte eine unspezifische Integration der Neomycin-Kassette beim nicht richtig homolog rekombinierten Allel beliebig auftritt, während das homolog rekombinierte Allel durch die Insertion der Kpn I-Schnittstelle im 3'-Ende der Neomycin-Kassette ein Fragment von $2.4 \mathrm{~Kb}$ anzeigt (Abb. 27B).

Durch die Hybridisierung mit der externen 5'-Sonde wurden von 72 ES-Zellklonen 4 ESZellklone als positiv identifiziert (Abb. 27A). Homolog rekombinierte Klone lassen sich durch die Anwesenheit der zusätzlichen kleineren DNA-Bande (14 Kb) identifizierten. Die Hybridisierung mit der Neomycin-Sonde zeigte bei den ES-Zellklonen \#31 und \#71 ein erwartetes Signal mit einer Größe von $2.4 \mathrm{~Kb}$, während sie beim ES-Zellklon \#9 ein unerwartetes Hybridisierungssignal mit einer Größe von ca. $1.8 \mathrm{~Kb}$ zeigte (Abb. 27B). Interessanterweise zeigte die ES-Zellinie \#67 sowohl ein erwartetes Signal mit einer Größe von $2.4 \mathrm{~Kb}$ als auch ein unerwartetes Signal mit einer Größe von ca. $1.8 \mathrm{~Kb}$. Für die Erklärung zum unerwarteten Signal wurden zwei Möglichkeiten diskutiert: 1. 'RandomIntegration' und 2. die sog. 'Star-Aktivität' des Restriktionsenzyms Kpn I wegen der langen Inkubation mit höherer Konzentration. 


\section{$M \quad \# 9 \quad \# 31 \quad \# 67 \quad \# 71$}

A

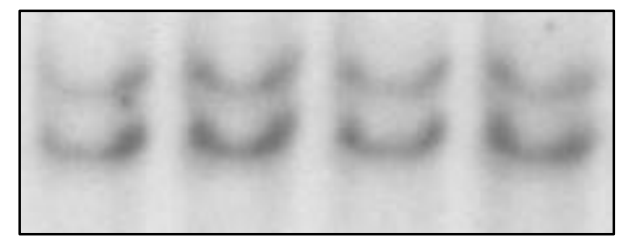

- W (17 Kb)

- M (14 Kb)

B

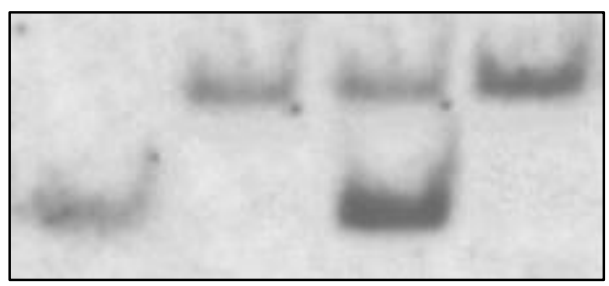

$-2.4 \mathrm{~Kb}$

$-1.8 \mathrm{~Kb}$

C

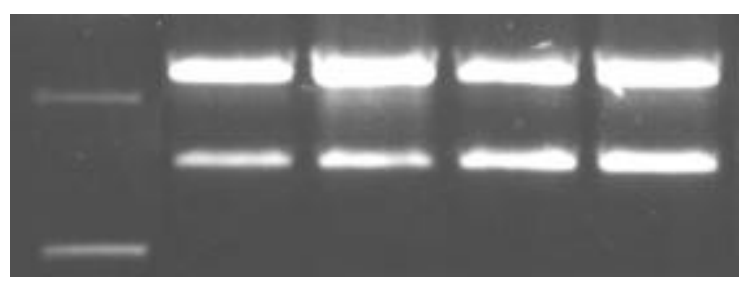

- W (1.1 Kb)

- M (0.8 Kb)

Abb. 27: Southern-Blot-Analyse mit DNA positiver ES-Zellklone nach Elektroporation mit dem Targeting-Vektor pPNT- $\triangle$ HASH.

A. Genomische DNA aus isolierten ES-Zellkolonien wurde mit Kpn I verdaut, gelelektrophoretisch aufgetrennt, auf eine Nitrocellulosemembran transferriert und mit der externen 5'-Sonde H5P (Abb. 24) hybridisiert. Das $17 \mathrm{~Kb}$ große Fragment repräsentiert das native Allel des HASH-Locus, während die $14 \mathrm{~Kb}$ Bande durch die Addition der Kpn I-Schnittstelle das rekombinante Allel anzeigt. Die Linien \#9, \#31, \#67 und \#71 sind heterozygot für die eingefügte Mutation.

B. Hybridisierung der selben Membran mit der internen Neomycin-Sonde. Die ES-Zellen \#31 und \#71 zeigen ein erwartetes Signal mit einer Größe von $2.4 \mathrm{~Kb}$, während mit der DNA aus den ESZellen \#9 ein zusätzliches Fragment mit ca. $1.8 \mathrm{~Kb}$ gefunden wurde.

C. Gelelektrophoretische Auftrennung der PCR-Produkte zur Analyse positiver ES-Zellen. $200 \mathrm{ng}$ der genomischen DNA wurden einer PCR mit den HASH-Allel-spezifischen Primern und dem Neomycin-Kassette-spezifischen Primer (s. Abb. 24) unterzogen. Dabei wurde eine WildtypAmplifikat mit einer Größe von $1.1 \mathrm{~Kb}$ und eine Amplifikat des mutierten Allels mit einer Größe von $0.8 \mathrm{~Kb}$ festgestellt.

$M=I K b$ DNA-Ladder (Gibco/BRL) 


\subsection{Aggregation bzw. Blastocysteninjektion von ES-Zellen}

Nach genomischer Charakterisierung der isolierten ES-Zellklone wurden die Zellen in flüssigem Stickstoff kryokonserviert. Für die Aggregation bzw. Blastocysteninjektion mit 2.5 Tage alten Mausembryonen des Mausstammes CD-1 wurden die Zellen vier Tage vor der Aggregation bzw. Blastocysteninjektion aufgetaut, auf Feederzellen ausgesäht und nach zwei Tagen im subkonfluenten Zustand erneut trypsinisiert und auf zwei $30 \mathrm{~mm}$ Kulturschalen verteilt. Für die Aggregation bzw. Blastocysteninjektion wurden zunächst die homolog rekombinierten ES-Zellklone \#31 und \#71 und später \#67 verwendet. Die Aggregate bzw. injizierten Blastocysten wurden in Ammenmäuse retransferriert, die geborenen Chimären anhand des Agouti-Fellmarkers identifiziert und durch Rückkreuzung mit Mäusen des Stammes NMRI auf Keimbahn-Transmission getestet. In Tabelle 1 sind die Ergebnisse aus den Aggregationen bzw. aus den Blastocysteninjektionen zusammengefaßt.

Tab. 1: Zusammenfassung der Ergebnisse aus den Aggregationen bzw. aus den Blastocysteninjektionen.

\begin{tabular}{c|c|c|c|c}
\hline \hline ES-Zellinie & $\begin{array}{c}\text { männliche } \\
\text { Chimären }\end{array}$ & $\begin{array}{c}\text { weibliche } \\
\text { Chimären }\end{array}$ & Agouti-Färbung & $\begin{array}{c}\text { Keimbahn- } \\
\text { Transmission }\end{array}$ \\
\hline \hline$\# 31$ & 5 & 1 & $5-30 \%$ & - \\
\hline$\# 67$ & 9 & - & $50-100 \%$ & ja \\
\hline$\# 71$ & 1 & 5 & $10-50 \%$ & - \\
\hline \hline
\end{tabular}

Die Genotypisierung der Nachkommen nach der Rückkreuzung zeigte, daß zwei männliche Chimären, die nach Blastocysteninjektion mit der Zellinie \#67 generiert werden waren, eine Keimbahn-Transmission des mutierten HASH-Allels realisierten. Bei den übrigen Chimären beteiligten sich die ES-Zellen mit dem rekombinierten Allel nicht an der 
Keimbahn. Nachkommen der transmittierenden Chimären, erkennbar an der braunen Fellfarbe, wurden durch eine PCR-Analyse genotypisiert (Abb. 28). Dabei war etwa die Hälfte der analysierten Mäuse heterozygot für die HASH Deletion. Heterozygote Mäuse zeigten keinerlei Auffälligkeiten. Um die Einflüsse des genetischen Hintergrunds auf die Auswirkung der HASH-Deletion zu verringern, wurden die männlichen Chimären \#18 und \#27 auch mit weiblichen Mäusen der Mäusestämme 129/SvJ und C57BL/6 verpaart.

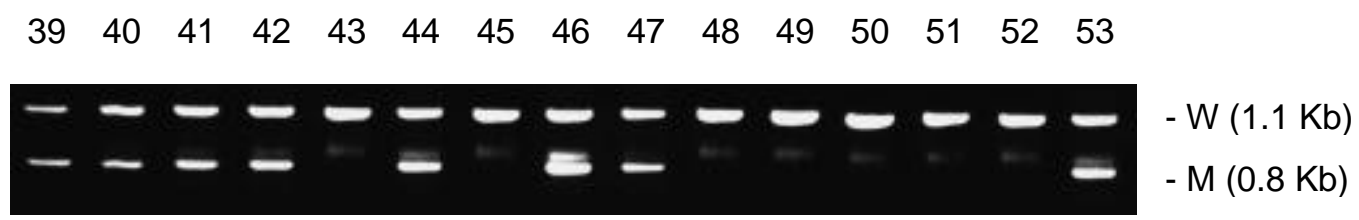

Abb. 28: Genotypisierung der Nachkommen der Chimäre \#18 durch PCR (Hintergrund NMRI).

Gelelektrophoretische Auftrennung der PCR-Produkte im 1\%igen Agarosegel zur Genotypisierung der Nachkommen aus der Verpaarung der Chimäre \#18 mit weiblichen Mäusen des Mausstammes NMRI. 200 ng genomische DNA wurden einer PCR mit den HASH-Allelspezifischen Primern und dem Neomycin-Kassette-spezifischen Primer (s. Abb. 24) unterzogen. Dabei wurden eine Wildtyp-Amplifikat mit einer Größe von $1.1 \mathrm{~Kb}$ und eine Amplifikat vom mutierten Allel mit einer Größe von 0.8 Kb erhalten. 


\subsection{Statistische Analyse der Nachkommen mittels PCR}

Durch Verpaarung der männlichen Chimären, die das mutierte HASH-Allel durch die Keimbahn transmittierten, mit weiblichen Mäusen der Stämme NMRI, 129/SvJ und C57BL/6 wurden in der F1-Generation heterozygote und Wildtyp-Nachkommen generiert.

Für die Genotypisierung der Nachkommen wurde bei drei Wochen alten Mäusen etwa $1 \mathrm{~cm}$ der Schwanzspitze abgeschnitten und die genomische DNA extrahiert. 200 ng der genomischen DNA wurden einer PCR mit den HASH-Allel-spezifischen Primern und dem Neomycin-Kassette-spezifischen Primer (s. Abb. 24) unterzogen. Dabei wurden ein WildtypAmplifikat mit einer Größe von $1.1 \mathrm{~Kb}$ und ein Amplifikat vom mutierten Allel mit einer Größe von $0.8 \mathrm{~Kb}$ erhalten.

Bei NMRI (Verpaarung der Chimäre \#18 mit weiblichen NMRI-Mäusen) betrug die Zahl der heterozygoten Mäuse 36 (50.7\%) bei einer Gesamtzahl von 71 in fünf Würfen. Bei 129/SvJ (Verpaarung der Chimäre \#18 mit weiblichen 129/SvJ-Mäusen) betrung der Anteil heterozygoter Nachkommen bei 3 Würfen mit insgesamt 30 Nachkommen 16 Tiere (53.3\%). Die Zahl der heterozygoten Mäuse war 10 (43.5\%) bei einer Gesamtzahl von 23 in drei Würfen auf C57BL/6 Hintergrund (Verpaarung der Chimäre \#27 mit weiblichen C57BL/6Mäusen). Diese Zahlen aus drei separaten Linien entsprechen den Erwartungen nach den Mendel'schen Vererbungsgesetzen. In Tabelle 2 sind die Ergebnisse aus den Verpaarungen für die F1-Generation zusammengefaßt.

Tab. 2: Quantitative Verteilung von Wildtyp- und heterozygoten Mäusen in der F1-Generation.

\begin{tabular}{l|c|c|c|c}
\hline \hline Hintergrund & $\begin{array}{c}\text { Anzahl der } \\
\text { Würfe }\end{array}$ & Gesamtzahl & Wildtyp & Heterozygot \\
\hline \hline NMRI & 5 & 71 & $35(49.3 \%)$ & $36(50.7 \%)$ \\
\hline $129 / \mathrm{SvJ}$ & 3 & 30 & $14(46.7 \%)$ & $16(53.3 \%)$ \\
\hline $\mathrm{C} 57 \mathrm{BL} / 6$ & 3 & 23 & $13(56.5 \%)$ & $10(43.5 \%)$ \\
\hline \hline
\end{tabular}


Männliche und weibliche heterozygote Mäuse auf jedem der drei Hintergründe wurden zum Zweck der Generierung homozygoter Mäuse miteinander verpaart. Nach der Verpaarung heterozygoter Eltern konnten keine homozygoten Mäuse durch PCRGenotypisierung identifiziert werden. In Tabelle 3 ist der Vergleich der Verteilung der genotypisierten Nachkommen zwischen F1- und F2-Generation auf NMRI-Hintergrund dargestellt.

Tab. 3: Vergleich der Verteilung von Wildtyp- heterozygoten und homozygoten Mäusen in der F1und F2-Generation auf NMRI-Hintergrund.

\begin{tabular}{c|c|c|c|c|c}
\hline \hline Generation & $\begin{array}{c}\text { Anzahl der Würfe } \\
\text { (Wurfgröße) }\end{array}$ & Gesamtzahl & Wildtyp & Heterozygot & Homozygot \\
\hline F1 & $5(14.2)$ & 71 & $35(49.3 \%)$ & $36(49.7 \%)$ & - \\
\hline F2 & $9(10.7)$ & 97 & $31(32.0 \%)$ & $66(68.0 \%)$ & $-(0 \%)$ \\
\hline \hline
\end{tabular}

Aus neun Verpaarung heterozygoter Tiere (auf NMRI-Hintergrund) wurden insgesamt 97 Nachkommen mit einer durchschnitlichen Wurfgröße von 10.7 geboren. Die Zahl der heterozygoten betrug 66 (68\%), während unter den 97 Nachkommen keine homozygote Maus gefunden werden konnte. Die signifikante Reduktion der Wurfgröße in der F2-Generation im Vergleich mit der F1-Generation ist erkennbar. Dieses Ergebnis führte zu der Annahme, daß HASH-defiziente Mäuse während der embryonalen Entwicklung absterben. 
Für die weitere Charakterisierung der HASH-defizienten Mäuse wurden embryonale Stadien untersucht. Nach der Verpaarung heteroyzgoter NMRI-Mäuse wurden die Embryonen am Tag 10.5 und 11.5 präpariert. Bei drei Embryonen von insgesamt 12 wurden Abnormalitäten des Kopfes (Reduktion der Kopfgröße) unter dem Binokular beobachtet. Insbesondere war der Bereich des Mesencephalons stark reduziert, das Mittelhirn stark abgeflacht. Um festzustellen, ob diese Abnormalität des Kopfes als Phänotyp der Deletion des HASH-Gens gewertet werden kann, wurde die Genotypisierung der Embryonen durch PCR durchgeführt. Überraschenderweise wurden die Embryonen mit Kopfabnormalität als heterozygote identifiziert. Um das Ergebnis der Genotypisierung durch PCR zu überprüfen, wurde dann die Southern-Blot-Analyse mit der DNA der oben genannten 12 Embryonen durchgeführt. Die Hybridisierung mit der externen Probe H5P (Abb. 24) zeigte, daß vier der 12 Embryonen homozygot waren (Abb. 29). Die Embryonen in Bahn 1, 2 und 3, die eine Abnormalität im Kopf hatten und als heterozygot mittels PCR identifiziert worden waren, wurden damit als homozygot nach Southern-Blot-Hybridisierung identifiziert. Außerdem wurde der Embryo in Bahn 8 der Abbildung 29, der morphologisch keine Abnormalität zeigte, ebenfalls als homozygot identifiziert.

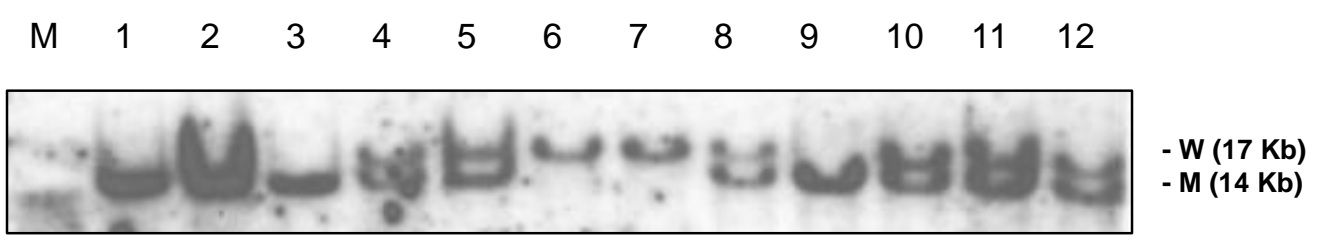

Abb. 29: Genotypisierung der 10.5 Tage alten Embryonen eines Wurfes der F2-Generation durch Southern-Blot-Analyse.

Genomische DNA aus 10.5-Tage alten Embryonen wurde mit Kpn I verdaut, gelelektrophoretisch aufgetrennt, auf eine Nitrocellulosemembran transferriert und mit der externen $5^{\prime}$-Sonde H5P hybridisiert. Das $17 \mathrm{~Kb}$ große Fragment repräsentiert das normale Allel des HASH-Locus, während die $14 \mathrm{~Kb}$ Bande durch die Addition der Kpn I-Schnittstelle das rekombinante Allel anzeigt. $M=1 \mathrm{~Kb}$ Ladder-DNA (GibcoBRL) 


\subsection{Genotypisierung von Nachkommen durch Southern-Blot-Analyse}

Um die unterschiedlichen Ergebnisse zwischen PCR- und Southern-Genotypisierung klar zu machen, wurde bei allen Mäusen der F2-Generation die Genotypisierung durch SouthernBlot-Hybridisierung mit der externen Probe H5P (Abb. 24) durchgeführt. In Abbildung 30 ist exemplarisch das Autoradiogramm einer Hybridisierung der DNA von Tieren aus der F2Generation (NMRI-Hintergrund) dargestellt. Dabei wurden die Mäuse 68, 86, 92, 93 und 94 in Abb. 30, die durch PCR als heterozygot typisiert worden waren, nun als homozygot identifiziert.

$\begin{array}{lllllllllllllll}68 & 72 & 85 & 86 & 92 & 93 & 94 & 96 & 6 & 9 & 10 & 11 & 37 & 42 & 98\end{array}$

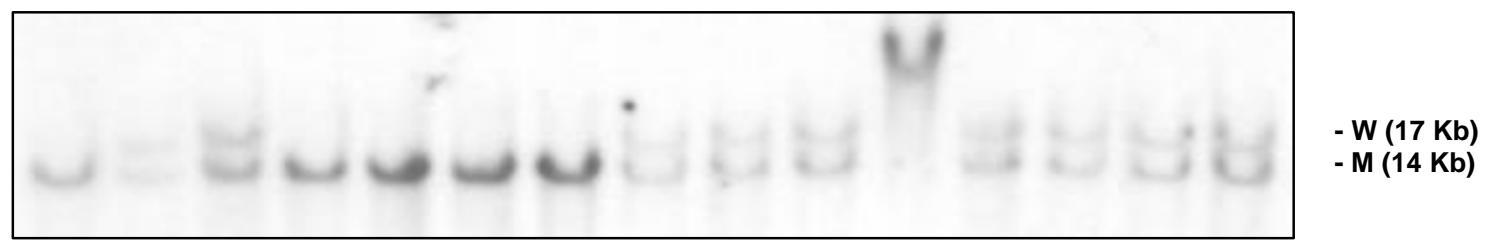

Abb. 30: Southern-Blot-Analyse zur Genotypisierung der F2-Generation (Hintergrund NMRI).

Hybridisierung genomischer DNA von Mäusen der F2-Generation, die durch PCR als heterozygot typisiert worden waren, mit der 5'-Sonde des HASH-Gens. Das Wildtyp-Allel zeigt ein Signal bei $17 \mathrm{~Kb}$, das mutierte Allel bei $14 \mathrm{~Kb}$. Die Mäuse 68, 86, 92, 93 und 94 sind homozygot für die eingefügte Mutation. 
In Tabelle 4 ist die quantitative Verteilung der durch die Southern-Blot-Hybridisierung genotypisierten Nachkommen der F2-Generation (auf NMRI-Hintergrund) im Vergleich mit den Ergebnissen nach PCR-Genotypisierung dargestellt. Der Anteil homozygoter Nachkommen belief sich bei 9 Würfen mit insgesamt 97 Nachkommen auf 17 Tiere (17.5\%), während die Zahl der Wildtyp-Mäuse 31 (32.0\%) betrug. Hier findet man eine geringe Reduktion sowohl bei heterozygoten als auch homozygoten Tieren.

Tab. 4: Quantitative Verteilung von Wildtyp-, heterozygoten und homozygoten Mäusen in der F2Generation (Hintergrund NMRI).

\begin{tabular}{c|c|c|c|c}
\hline \hline Analysemethode & Gesamtzahl & Wildtyp & Heterozygot & Homozygot \\
\hline \hline PCR & 97 & $31(32.0 \%)$ & $66(68.0 \%)$ & $-(0 \%)$ \\
\hline $\begin{array}{c}\text { Southern- } \\
\text { Hybridisierung }\end{array}$ & 97 & $31(32.0 \%)$ & $49(50.5 \%)$ & $17(17.5 \%)$ \\
\hline \hline
\end{tabular}

Homozygote Nachkommen unterscheiden sich nach einer äußeren, makroskopischen Analyse in keiner Weise von ihren heterozygoten bzw. Wildtyp-Geschwistern und zeigen keine Auffälligkeiten. Durch die Verpaarung von sechs mutanten Männchen mit WildtypWeibchen und von acht mutanten Weibchen mit Wildtyp-Männchen wurde es festgestellt, daß alle homozygoten Mäuse fertil sind. 


\subsection{Erklärung des Ereignisses in Genom der Versuchsmäuse}

Das HASH-Allel bei diesen Mäusen sollte wegen der unterschiedlichen Ergebnisse bei der PCR- und bei der Southern-Genotypisierung genauer charakterisiert werden. Es soll darauf hingewiesen werden, daß die homologe Rekombination durch 'crossing over' in den ursprünglichen ES-Zellen mit der externen Probe H5P festgestellt worden war. Für die weitere Charakterisierung wurden eine externe Probe in der 3'-flankierenden Region bzw. eine interne Probe, die im deletierten Bereich lokalisiert, benötigt. Wegen repetitiver Sequenzen war die Herstellung einer externen Probe im 3'-flankierenden Bereich des Konstrukts nicht möglich.

\subsubsection{Southern-Blot-Hybridisierung mit der internen Probe}

Zunächst wurde überprüft, ob bei den Mäusen das putative Translationsstartkodon in Exon 3 tatsächlich deletiert ist. Dazu wurde die interne Probe HIP (Abb. 24), die in der 5'-Region des Exons 3 lokalisiert, mit PCR amplifiziert, sequenziert und auf den Blot in Abbildung 30 hybridisiert. Damit sollte nur das Wildtyp-Allel des HASH-Gens mit einer Größe von 17 Kb detektiert werden. Wie die Abbildung 31 zeigt, wurde eine unerwartete, zusätzliche Bande mit einer Größe von $11 \mathrm{~Kb}$ sichtbar, was bedeutet, daß bei diesen Mäusen die Deletion der beiden Exons durch homologe Rekombination nicht stattgefunden hat. 
A
$\begin{array}{lllllllllllllll}68 & 72 & 85 & 86 & 92 & 93 & 94 & 96 & 6 & 9 & 10 & 11 & 37 & 42 & 98\end{array}$

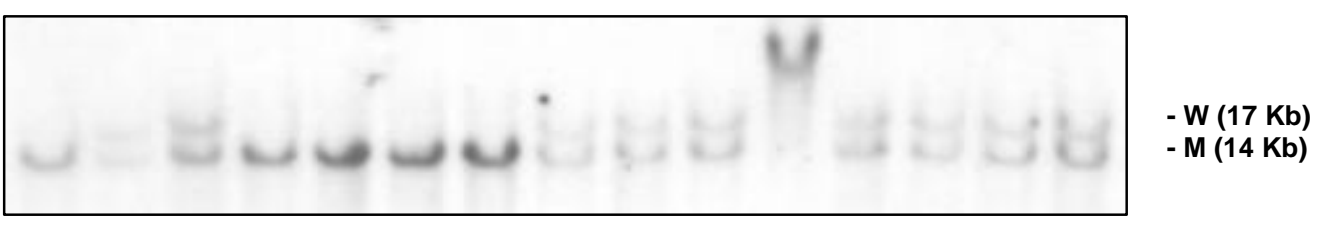

B

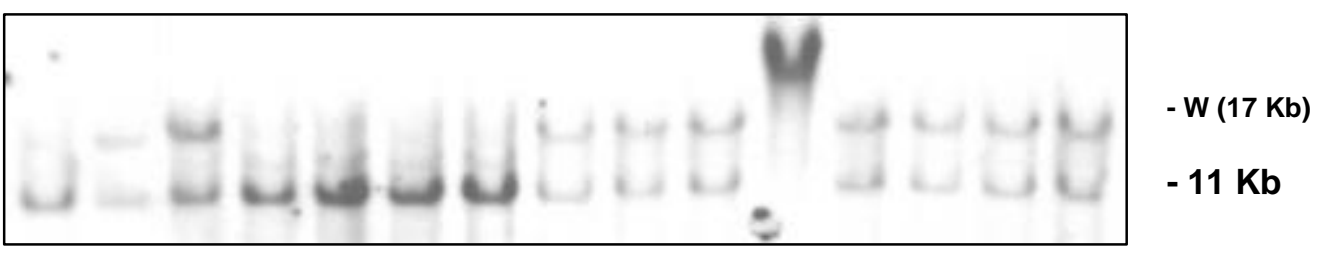

Abb. 31: Southern-Blot-Hybridisierung mit der internen Probe HIP.

A. Hybridisierung genomischer DNA von Mäusen der F2-Generation, die durch PCR als heterozygot identifiziert wurden, mit der 5'-Sonde des HASH-Gens. Das Wildtyp-Allel zeigt ein Signal bei $17 \mathrm{~Kb}$, das mutierte Allel bei $14 \mathrm{~Kb}$. Die Mäuse 68, 86, 92, 93 und 94 sind homozygot für die eingefügte Mutation.

B. Nachhybridisierung der selben Membran mit der internen Sonde HIP (Abb. 24). Damit sollte nur das Wildtyp-Allel des HASH-Gens mit einer Größe von $17 \mathrm{~Kb}$ detektiert werden. Hierbei wurde jedoch eine unerwartete, zusätzliche Bande mit einer Größe von $11 \mathrm{~Kb}$ hybridisiert.

\subsubsection{Integration des Konstrukts innerhalb des $5^{\prime}$-flankierenden Bereichs : HASH $^{\text {neo/neo }}$-Insertion- statt HASH ${ }^{-/}$-Knock out-Mäuse}

Aus allen Daten einschließlich der Ergebnisse der Southern-Blot-Hybridisierung wurde eine mögliche Erklärung für die Ereignisse in Genom der Versuchsmäuse herausgefunden werden. Normalerweise findet der Genaustausch zur Inaktivierung durch die homologe Rekombination statt, die durch 'crossing over' in beiden 5'- und 3'-flankierenden Bereichen vermittelt wird. Statt homologer Rekombination in den 5'- und 3'-flankierenden Bereichen erfolgte bei uns die Integration des vollständigen oder partiellen Konstrukts innerhalb der 5'-flankierenden Region. Das könnte passiert sein durch 
ein 'crossing over' nur in einem flankierenden Fragment, in diesem Fall im 5'-flankierenden Fragment, und anschließender Integration des freihängenden 3'-Endes im 5'-flankierenden Bereich. Dadurch wurde die Neomycin-Kassette als Selektionsmarker innerhalb von Introns 2 zwischen Exon 2 und Exon 3 des HASH-Gens der Maus inseriert (HASH ${ }^{\text {neo/neo }}-$ Insertion).

\subsection{Weitere Versuche zur Herstellung der homozygoten HASH $^{-/}$-Mäuse}

Wie in Tabelle 1 erwähnt wurde, haben bei mehreren Verpaarungen Chimären, die aus den ES-Zellen \#31 und \#71 generiert wurden, keine Keimbahn-Transmission gezeigt. Um neue Chimären $\mathrm{zu}$ erzeugen, wurden die Aggregationen und die Blastocysten-Injektionen erneut mit den ES-Zellen \#31 und \#71 durchgeführt. Trotz mehrmaliger Versuche ist es nicht gelungen, eine Chimäre zu produzieren. Ein Grund dafür könnte die Alterung der ES-Zellen sein. Daher wurde die Elektroporation in RI-ES-Zellen mit dem Targeting-Vektor pPNT$\triangle \mathrm{HASH}$ erneut durchgeführt. Durch Southern-Blot-Hybridisierung mit der externen 5'-Sonde H5P (Abb. 24) und der internen Sonde HIP (Abb. 24) bzw. Neo wurden die zwei ES-ZellKlone, \#72 und \#96 (von insgesamt 97 Neo-positiven ES-Zellen) als heterozygot für die eingefügte Mutation identifiziert (Daten nicht gezeigt). 


\section{DISKUSSION}

\section{Analyse der HASH-cDNAs der Maus}

Mit Hilfe einer partiellen HASH-cDNA der Ratte (800 Bp; Aho, 1997) konnten drei überlappende cDNA-Klone aus einer Maustestis-cDNA-Bibliothek isoliert werden. Die Vervollständigung der HASH-cDNA der Maus erfolgte über die Amplifikation des 5'- bzw. 3'-Bereiches mit Hilfe der Marathon-RACE-PCR (s. III.2.3). Aus den Sequenzen der cDNAKlone und der RACE-PCR-Produkte konnte die gesamte HASH-cDNA-Sequenz mit Hilfe des Computerprogrammes „GCG-Paket“ (Genetics Computer Group, Wisconsin, USA) erstellt werden. Die HASH-cDNA-Sequenz hat eine Länge von 2678 Bp. Das erste ATGKodon befindet sich an Position 1144 (Abb. 16), und das zweite ATG liegt an Position 1318 (Abb. 16). Die flankierende Sequenz des zweiten ATG ist CCAGAATGG und korreliert mit

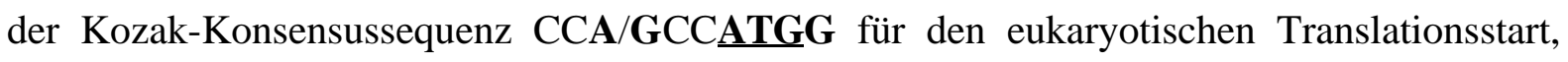
wobei ein Purin in der Position -3 und ein Guanin in der Position +4 in allen eukaryotischen mRNAs konserviert sind (Kozak, 1989). Der putative, offene Leserahmen beginnt mit dem zweiten Translationsstartkodon an Position 1318 und hat eine Länge von 1290 Bp (kodiert für 430 Aminosäuren). Der 3'-nichttranslatierte Bereich erstreckt sich über $68 \mathrm{Bp}$ und enthält ein modifiziertes Polyadenylierungssignal AATGAAA (Sheets et al., 1990), das 18 Bp vom Poly(A)-Schwanz entfernt ist. Solche modifizierten Polyadenylierungssignale wurden u. a. für das Transitionsprotein 2 (ATTAAA; Kleene und Flynn, 1987; Luerssen et al., 1989) und für Untereinheiten von cAMP-abhängigen Proteinkinasen in männlichen Keimzellen (Oyen et al., 1990) beschrieben.

Die mehrmaligen Versuche zur Identifizierung des Transkriptionsstartpunktes des HASHGens mittels der Primer-Extension-Analyse ergaben keine eindeutigen, sondern multiple Signale für den Transkriptionsstartpunkt. Auch die Ergebnisse der Amplifikation mit Hilfe der Marathon-RACE-PCR im 5'-Bereich und die anschließende Hybridisierung des PCRProduktes (Abb. 11) lassen die Annahme $\mathrm{zu}$, daß beim HASH-Gen multiple Transkriptionsstartpunkte genutzt werden. Es sind zahlreiche Gene mit multiplen Transkriptionsstartpunkten bekannt. Bei dem Gen für die Thymidylat-Synthase startet z.B. 
die Transkription an verschiedenen Stellen über einen Bereich von 90 Basen des sog. 'initiation window' (Geng und Johnson, 1993).

Im 5'-nichttranslatierten Bereich an Position 948 bis 1143 (ca. 200 Bp) der HASH-cDNASequenz von Maus und Ratte befindet sich eine GC-reiche Region (87\%). Es ist bekannt, daß eine GC-reiche Region im 5'-nichttranslatierten Bereich sowohl bei der transkriptionellen als auch bei der translationellen Regulation eine Rolle spielt. Das Gen für die Dipeptidylpeptidase IV (DPP IV), als ein Beispiel für eine transkriptionelle Regulation über eine GC-reiche Region im 5'-nichttranslatierten Bereich, hat einen 89 Bp langen, in beiden Richtungen vollfunktionellen Promotor vor dem ATG (Qvist et al., 1998). Die humane Basonuklin-mRNA, als ein Beispiel für eine translationelle Regulation über eine GCreiche Region im 5'-nichttranslatierten Bereich, bildet infolge des hohen GC-Gehaltes eine stabile Sekundärstruktur und dadurch wird ihre Translation inhibiert (Tang und Tseng, 1999). Es ist also vorstellbar, daß die GC-reiche Region im 5'-nichttranslatierten Bereich des HASH-cDNA eine ähnliche Rolle wie die des DPP IV- bzw. des Basonuklin-Gens spielt, nämlich bei der transkriptionellen bzw. translationellen Regulation.

Auffällig ist, daß die 5'-UTR (5'-untranslated region) der HASH-cDNA eine Wiederholungssequenz von 30 Bp enthält. Die dreifache Wiederholung der 30 Bp-Nukleotide befindet sich an Position 701 (617 Bp vor dem ATG-Kodon); dieser Anteil des Gens ist nur in der 2.6 Kb HASH-mRNA vorhanden. In der Literatur wurden Repeats für Trinukleotide (z. B. für CAG, CTG oder TTA usw.) beschrieben. Die Expansion dieser Trinukleotidsequenzen ('expansion mutation') ist als Ursache bei genetisch bedingten Erkrankungen bekannt, etwa bei der Chorea Huntington, beim Martin-Bell-Syndrom und bei der Mytonendystrophie (Margolis et al., 1999). Bislang gibt es keine Hinweise in der Literatur, daß auch Repeats von 30 oder mehr Basenpaaren in der 5'-nichttranslatierten Region tatsächlich für erblich bedingte Erkrankungen in Frage kommen. Die Repeats könnten wichtig sein als cisständige Elemente, oder sie könnten über die Beeinflußung der Sekundärstruktur der mRNA die Transkriptstabilität verändern. 
Nach den Ergebnissen von Gold und Hecht (1981) kann ein ungewöhlich langer Poly(A)Schwanz für die Translationsregulation haploid exprimierter Transkripte im Testis wichtig sein. Lange Zeit wurde davon ausgegangen, daß das haploide Genom in der Spermiogenese inaktiv ist und die gesamte Spermatogenese der Kontrolle des diploiden Genoms unterliegt. Durch Isolierung von mRNAs aus fraktionierten Pachytänspermatozyten, frühen runden Spermatiden und sich elongierenden Spermatiden wurde gezeigt, daß nur 50\% der mRNA in den frühen runden Spermatiden mit Polysomen assoziiert vorliegt, d.h. translatiert wird (Stern et al., 1983). Es wurde angenommen, daß im Spermatidenzytoplasma ein Vorrat an mRNA vorhanden ist, der aus der diploiden Phase der Spermatogenese stammt und in den sich elongierenden Spermatiden translatiert wird (Eddy et al., 1993; Hecht, 1993). Zwischenzeitlich konnte jedoch eindeutig gezeigt werden, daß es Genexpression in den haploiden Spermatiden gibt, die Transkripte über mehrere Tage konserviert und dann im Verlauf der Spermiogenese translatiert werden. Als Beispiele seien an dieser Stelle die mRNAs für die Gene Transitionsprotein 1 und 2 (TP 1 und TP2), Protamin 1 und 2 (P1 und P2) und MCS ('selenoprotein in the mitochondrial capsule') genannt (Schäfer et al., 1995). Die Verzögerung der Translation der haploid exprimierten Gene kann auf den ungewöhnlich langen Poly(A)-Schwanz der mRNAs zurückgeführt werden (Kleene, 1989). Um zu überprüfen, ob dieser Kontrollmechanismus für die Translation der haploidspezifischen HASH-Transkripte gilt, wurde die Länge des Poly(A)-Schwanzes der HASH-mRNAs durch Verdau mit RNaseH analysiert. Sie beträgt maximal 100 Bp (Abb. 6). Dieser Befund läßt die Annahme zu, daß keine Translationsregulation der HASH-mRNAs in der Spermatogenese aufgrund eines ungewöhnlich langen Poly(A)-Schwanzes stattfindet.

Der Vergleich der HASH-cDNA-Sequenz mit den Nukleotidsequenzen in den Datenbanken EMBL sowie GenBank zeigte keine signifikante Homologie zu bekannten Sequenzen, während der Vergleich mit den EST-Datenbanken Homologien zu einer Vielzahl von EST-Klonen von Maus, Ratte und Mensch ergab. In Tabelle 5 sind die zur HASH-cDNA homologen Klone aus den EST-Datenbanken zusammengefaßt. Die Homologie auf Nukleotidebene zwischen der HASH-cDNA von Ratte und Maus beträgt ca. 97\%. Dabei beschränken sich die hochkonservierten Bereiche bei den HASH-Genen von Maus und Ratte nicht nur auf den kodogenen Bereich, sondern weisen einen ebenso hohen Homologiegrad in der 5'- und 3'-nichttranslatierten Region auf. Die Homologie zwischen der HASH-cDNA von Maus und der vier EST-Sequenzen des Menschen beträgt ca. $88 \%$. 
Tab. 5: Zusammenstellung der homologen EST-Klone der HASH-cDNA (Maus, Ratte und Mensch); es wurden die Originaleinträge in den EST-Datenbanken übernommen.

\begin{tabular}{|c|c|c|}
\hline ID & Beschreibung & Homologie \\
\hline $\mathrm{AF} 032967$ & $\begin{array}{l}\text { Mus musculus strain C3H/HeN mRNA preferentially } \\
\text { expressed in LPS-normoresponsive macrophages }\end{array}$ & $948 / 975 \quad(97 \%)$ \\
\hline AA839623 & vw97e07.r1 Soares 2NbMT Mus musculus cDNA clone & $679 / 719 \quad(94 \%)$ \\
\hline AI747975 & $\begin{array}{l}\text { ul04f09.y1 Sugano mouse kidney mkia Mus } \\
\text { musculus cDNA clone }\end{array}$ & $559 / 568 \quad(98 \%)$ \\
\hline AA387131 & $\begin{array}{l}\text { vc22a04.r1 Ko mouse embryo } 11 \text { 5dpc Mus musculus } \\
\text { cDNA clone }\end{array}$ & $512 / 514 \quad(99 \%)$ \\
\hline AI046732 & $\begin{array}{l}\text { uh54d12.r1 Soares mouse embryonic stem cell } \\
\text { NMES Mus musculus cDNA clone }\end{array}$ & $479 / 488 \quad(98 \%)$ \\
\hline W34515 & $\begin{array}{l}\text { mc57c11.r1 Soares mouse embryo NbME13.5 } 14.5 \\
\text { Mus musculus cDNA clone }\end{array}$ & $536 / 560 \quad(95 \%)$ \\
\hline AI046560 & $\begin{array}{l}\text { uh27b01.r1 Barstead mouse testis MPLRB11 Mus } \\
\text { musculus cDNA clone }\end{array}$ & $500 / 515 \quad(97 \%)$ \\
\hline AA790543 & $\begin{array}{l}\text { vw17g06.r1 Soares mouse mammary gland NbMMG Mus } \\
\text { musculus cDNA clone }\end{array}$ & $455 / 462 \quad(98 \%)$ \\
\hline AI 412950 & $\begin{array}{l}\text { EST241250 Normalized rat brain, Bento } \\
\text { Soares Rattus sp. cDNA clone }\end{array}$ & $424 / 450 \quad(94 \%)$ \\
\hline AA615706 & $\begin{array}{l}\text { vo79h08.r1 Barstead mouse myotubes MPLRB5 Mus } \\
\text { musculus cDNA clone }\end{array}$ & $420 / 436 \quad(96 \%)$ \\
\hline AA273873 & $\begin{array}{l}\text { vb96a08.r1 Soares mouse lymph node NbMLN Mus } \\
\text { musculus cDNA clone }\end{array}$ & $299 / 301 \quad(99 \%)$ \\
\hline AI240133 & $\begin{array}{l}\text { qh34c10.x1 Soares_NFL_T_GBC_S1 Homo } \\
\text { cDNA clone }\end{array}$ & $413 / 456 \quad(90 \%)$ \\
\hline AA769927 & $\begin{array}{l}\text { ah95d05.s1 Soares NFL T GBC S1 Homo sapiens } \\
\text { cDNA clone }\end{array}$ & $275 / 310(88 \%)$ \\
\hline AI139608 & $\begin{array}{l}\text { qd79e09.x1 Soares_testis_NHT Homo sapiens cDNA } \\
\text { clone }\end{array}$ & $273 / 309 \quad(88 \%)$ \\
\hline AA758994 & $\begin{array}{l}\text { ai29d03.s1 Soares testis NHT Homo sapiens cDNA } \\
\text { clone }\end{array}$ & $272 / 309 \quad(88 \%)$ \\
\hline
\end{tabular}




\section{Analyse der Primärstruktur des HASH-Proteins der Maus}

Mit Hilfe des Computerprogramms (ORF finder, NCBI) wurde für die HASH-cDNA ein offener Leserahmen ermittelt, der sich von Position 1144 bis 2607 der HASH-cDNASequenz erstreckt. Das daraus abgeleitete Translationsprodukt hat ein Molekulargewicht von ca. 56.2 KDa. An Position 1318 der cDNA befindet sich ein mit der KozakKonsensussequenz kompatibles zweites ATG-Kodon. Legt man dieses ATG zugrunde, dann kann ein Polypeptid mit ca. 49.7 KDa abgeleitet werden. Die Western-Blot-Analyse mit dem gegen ein HASH-Oligopeptid hergestellten HASH-Antiserum (Abb. 17) ergab, daß ein HASH-Protein mit einer Größe von ca. $53 \mathrm{KDa}$ in Testis, Ovar, Thymus und Gehirn vorhanden ist. Unter Berücksichtigung einer posttranslationellen Modifikation, z.B. durch Phosphorylierung (Cruzalegui et al., 1999) oder die Bindung von ATP/GTP (Husain et al., 1995), ist der Schluß zulässig, daß das 53 KDa große HASH-Protein das tatsächlich entstehende HASH-Protein ist und durch das zweite ATG-Kodon an Position 1318 der cDNA, das der Konsensus-Sequenz für die Initiation der Translation bei Eukaryonten entspricht, entsteht.

Die Aminosäurezusammensetzung des HASH-Proteins ist in Tabelle 6 dargestellt, wobei die basischen Aminosäuren Arginin (9.5\%), Lysin (6.3\%) und Histidin (5.1\%) häufig vorkommen und damit das HASH-Protein als basisch (isoelektrischer Punkt: $\mathrm{pI}=8.57$ ) einzustufen ist. Die Aminosäure Serin, die eine als Phosphorylierungsstelle fungierende Hydroxyl(-OH)-Gruppe besitzt, ist am häufigsten (11.6\%) vertreten. Mit Hilfe des Computerprogramms (,MotifFinder“ und „PPSEARCH“) wurden einige Serin enthaltende Sequenzmotive als putative Phosphorylierungstellen identifiziert (Tab. 7). 
Tab. 6: Aminosäurezusammensetzung des HASH-Proteins der Maus.

Die Aminosäurezusammensetzung ist aus der entsprechenden HASH-cDNA abgeleitet. Die Anzahl der Aminosäuren und ihr prozentualer Anteil im Gesamtprotein sind angegeben. Relativ häufig vorkommende Aminosäuren ( $H, R$ und $S$ ) sind fett markiert.

\begin{tabular}{|c|c|c||c|c|c|}
\hline Aminosäure & Anzahl & Anteil (\%) & Aminosäure & Anzahl & Anteil (\%) \\
\hline A & 16 & 3.7 & M & 8 & 1.9 \\
\hline C & 17 & 4.0 & N & 12 & 2.8 \\
\hline D & 30 & 7.0 & P & 33 & 7.7 \\
\hline E & 31 & 7.2 & Q & 13 & 3.0 \\
\hline F & 18 & 4.2 & R & 41 & 9.5 \\
\hline G & 16 & 3.7 & S & 50 & 11.6 \\
\hline H & 22 & 5.1 & T & 22 & 5.1 \\
\hline I & 11 & 2.6 & V & 21 & 4.9 \\
\hline K & 27 & 6.3 & W & 3 & 0.7 \\
\hline L & 25 & 5.8 & Y & 14 & 3.3 \\
\hline
\end{tabular}

Aufgrund der Analysen mit den Computerprogrammen „SOSUI“ (Prediction of Transmembrane Segments; Hirokawa et al., 1998) und „TSEG“ (Prediction of Membrane Proteins; Kihara et al., 1998), bei denen keine Transmembranmotive gefunden werden konnten, wurde das HASH-Protein als ein lösliches Protein eingestuft. Durch eine weitere Computeranalyse mit dem Programm „PSORT“ (Prediction of Protein Sorting Signals; Nakai and Horton, 1999) wird die zelluäre Lokalisation des HASH-Proteins wie folgt vorhergesagt: im Kern mit einer Wahrscheinlichkeit von 47.8\%, im Cytoplasma von $30.4 \%$, in den Mitochondrien von 8.7\% und als cytoskelettales Protein von 13.0\%.

Mit Hilfe der Computerprogramme „MotifFinder“ (http://motif.genome.ad.jp/MOTIF.html) und „PPSEARCH“ (http://www2.ebi.ac.uk/ppsearch/) wurden in der Protein-Datenbank „Prosite“ einige Motive der HASH-Proteinsequenz ermittelt. Dabei wurden mehrere konservierte Sequenzen für Phosphorylierungsstellen (Tab. 7) und eine hochkonservierte ATP/GTP-Bindungsstelle (AASCKGKS) an Position 392-399 identifiziert. 
Tab. 7: Zusammenstellung der putativen Phosphorylierungsstellen des HASH-Proteins.

\begin{tabular}{|c|c|c|c|}
\hline Gefundenes Motiv & Positon & $\begin{array}{l}\text { Aminosäure- } \\
\text { Sequenz }\end{array}$ & Phosphorylierungsstelle der \\
\hline CAMP_phospho_site & $\begin{array}{l}71-74 \\
130-133 \\
190-193\end{array}$ & $\begin{array}{l}\text { RRIS } \\
\text { KKKS } \\
\text { KKET }\end{array}$ & $\begin{array}{l}\text { CAMP- und CGMP-abhängigen } \\
\text { Proteinkinase }\end{array}$ \\
\hline CK2_phospho_site & $\begin{array}{l}41-44 \\
303-307 \\
366-369\end{array}$ & $\begin{array}{l}\text { STYD } \\
\text { SLRER } \\
\text { SDPE }\end{array}$ & Caseinkinase II \\
\hline TYR_phospho_site & $\begin{array}{l}102-108 \\
134-142\end{array}$ & $\begin{array}{l}\text { RTQDKFT } \\
\text { KSPERSKYC }\end{array}$ & Tyrosinkinase \\
\hline
\end{tabular}

Die Sequenzhomologie zwischen Maus und Ratte beträgt 97.9\% in 430 Aminosäuren (Abb. 32). Die Aminosäuresequenz des humanen HASH-Proteins wurde aus vier humanen ESTKlonen (AI240133, AA769927, AI139608 und AA758994 in Tab. 5) abgeleitet und zeigt $\mathrm{zu}$ der der HASH-Aminosäuresequenz der Maus eine Identität von $88.7 \% \quad(90.3 \%$ Ähnlichkeit) über einen Abschnitt von 231 Aminosäuren (Abb. 32). Dieser hohe Homologiegrad zwischen den drei Spezies läßt die Annahme zu, daß das HASH-Gen bzw.Protein bei diesen drei Spezies hoch konserviert ist.

Abb. 32: Vergleich der aus den cDNA-Sequenzen des HASH-Gens von Maus, Ratte und des Menschen abgeleiteten Aminosäuresequenzen.

M=Maus; $R=$ Ratte; $H=$ Mensch.

: = Identität; . = Ähnlichkeit 


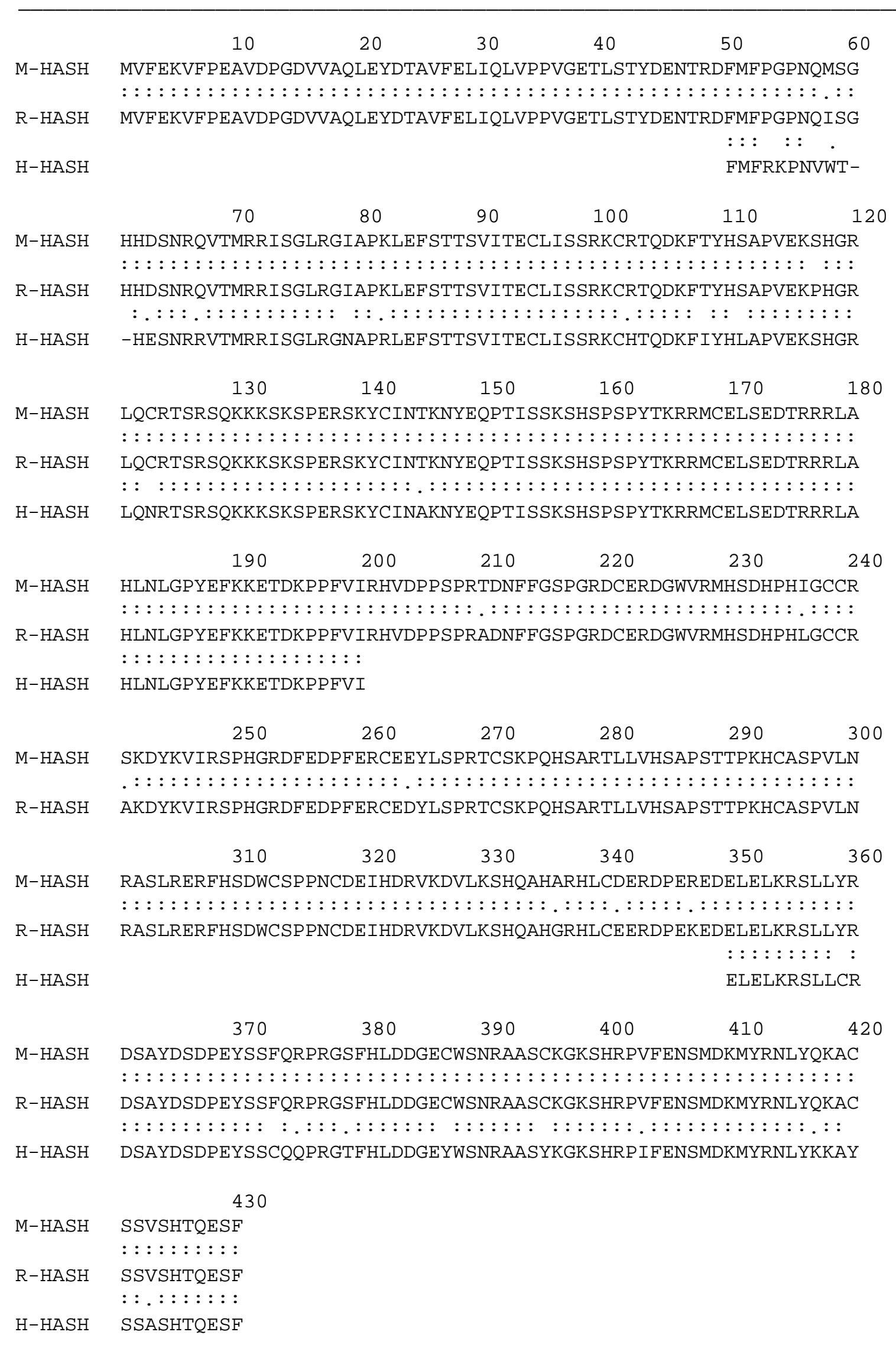




\section{Expressionsanalyse des HASH-Gens in der Maus}

Für die Untersuchung der Expression des HASH-Gens in der Maus wurde die Hybridisierung von Gesamt-RNA aus verschiedenen Geweben der Maus mit der HASH-cDNA H-800 durchgeführt (Abb. 1). Dabei wurden drei Transkripte für das HASH-Gen im Testis mit einer Größe von $2.6 \mathrm{~Kb}, 1.8 \mathrm{~Kb}$ und $1.2 \mathrm{~Kb}$ identifiziert, während in der RNA aus Ovar, Thymus, Placenta und Gehirn nur ein Transkript von $2.6 \mathrm{~Kb}$ nachweisbar war. Dieses Expressionsmuster in der Maus entspricht dem des HASH-Gens in der Ratte (Aho, 1997). Es wurde allerdings ein Unterschied zwischen Maus und Ratte in der Intensität der einzelnen Transkripte beobachtet. In der Maus ist im Testis das $1.8 \mathrm{~Kb}$ Transkript prominent, während im Testis der Ratte das 1.2 Kb Transkript bevorzugt darstellbar ist. Eine Erklärung dafür könnte sein, daß das HASH-Gen verschiedene Promotoren besitzt, die die Transkription der verschiedenen mRNAs in verschiedenen Spezies unterschiedlich regulieren.

Um zu klären, welches der drei HASH-Transkripte in welcher Phase der Spermatogenese nachweisbar ist, wurde die Gesamt-RNA aus Testes von 5- bis 50-Tage alten Mäusen mit der HASH-cDNA H-800 hybridisiert (Abb. 2). Das größte Transkript von $2.6 \mathrm{~Kb}$ konnte in der RNA aus Maustestes aller Enwicklungsstadien identifiziert werden, während die $1.8 \mathrm{~Kb}$ und 1.2 Kb-Transkripte erst in der RNA aus 25-Tage altem Testis detektiert werden konnten. Bei der Maus beginnt am Tag 15 der postnatalen Testisentwicklung die Meiose. Die ersten haploiden Stadien werden am Tag 20 gefunden (Clermont et al., 1992). Unter Berücksichtigung dieser Angaben kann gefolgert werden, daß das $2.6 \mathrm{~Kb}$ HASHTranskript in allen Spermatogenesestadien exprimiert ist, während die $1.8 \mathrm{~Kb}$ und $1.2 \mathrm{~Kb}$ HASH-mRNAs nur in haploiden Keimzellen exprimiert sind. Um diese haploide Expression weiter zu bestätigen, wurde ein Northern-Blot mit Gesamt-RNA aus Testis von W/W ${ }^{\mathrm{V}}$-, $\mathrm{Tfm} / \mathrm{Y}-$, olt/olt, qk/qk-Mausmutanten, bei denen die Spermatogenese in unterschiedlichen Stadien unterbrochen ist, mit der HASH-cDNA H-800 hybridisiert (Abb. 3). Die Hybridisierungen zeigten, daß in den Testes der $\mathrm{W} / \mathrm{W}^{\mathrm{V}}$ - und $\mathrm{Tfm} / \mathrm{Y}-\mathrm{Mausmutanten}$ nur ein Transkript von $2.6 \mathrm{~Kb}$ vorhanden ist, während bei den olt/olt- und qk/qk-Mausmutanten alle drei HASH-Transkripte detektiert werden können. Bei den Testes von $\mathrm{W} / \mathrm{W}^{\mathrm{V}}$ - und $\mathrm{Tfm} / \mathrm{Y}$ Mausmutanten fehlen die haploiden Zellen (Koshimizu et al., 1992; Gaspar et al., 1991), was mit dem Fehlen der zwei HASH-Transkripte von $1.8 \mathrm{~Kb}$ und $1.2 \mathrm{~Kb}$ korreliert. Da bei der 
$\mathrm{W} / \mathrm{W}^{\mathrm{V}}$-Mutante keine Keimzellen im Testis vorhanden sind, muß das Signal des $2.6 \mathrm{~Kb}$ HASH-Transkriptes aus somatischen Zellen (Leydig- und Sertolizellen) stammen. Bei den Mausmutanten olt/olt und qk/qk ist die Spermatogenese nach der Phase der frühen, runden Spermatiden bzw. mittleren bis elongierten Spermatiden blockiert (Moutier, 1976; Sidman et al. 1964). Die Detektion der HASH-Transkripte von $1.8 \mathrm{~Kb}$ und $1.2 \mathrm{~Kb}$ bei der olt/olt- und qk/qk-Mausmutanten kann daher auf das Vorhandensein der haploiden Keimzellen zurückgeführt werden. Diese Experimente bestätigen, daß die 1.8 und $1.2 \mathrm{~Kb}$ HASHTranskripte nur in haploiden Keimzellen exprimiert werden.

Obwohl die drei HASH-Transkripte im Testis der Maus exprimiert sind, zeigte die WesternBlot-Analyse mit dem gegen ein HASH-Oligopeptid gerichteten polyklonalen HASHAntikörper, daß nur ein $53 \mathrm{KDa}$ großes HASH-Protein im Testisextrakt vorhanden ist. Aus diesem Ergebnis kann gefolgert werden, daß das keimzellspezifisch exprimierte $1.2 \mathrm{~Kb}$ HASH-Transkript nicht translatiert wird. Es ist noch unklar, ob das zweite keimzellspezifisch exprimierte $1.8 \mathrm{~Kb}$ HASH-Transkript translatiert wird. Mit der in situ-immunhistochemischen Färbung von Testisschnitten mit dem HASH-Antiserum könnte diese Frage beantwortet werden. Diese Arbeiten werden derzeit durchgeführt.

Außer in Ovar, Placenta, Thymus und Gehirn wird das HASH-Transkript von $2.6 \mathrm{~Kb}$ auch in Lymphknoten und in der Milchdrüse der adulten Maus und in embryonalen Muskelzellen detektiert. Die Expression in Lymphknoten, Milchdrüsen und Muskelzellen ergibt sich aus dem Nachweis von EST-Klonen in der Datenbank. Diese Befunde führen zur Annahmme, daß das HASH-Protein nicht nur eine Funktion in der Spermatogenese, sondern auch in der Entwicklung anderer Organe besitzt. In einer weiteren Northern-Blot-Analyse wurde untersucht, in welchen anderen Zelltypen von Testis das große Transkript von $2.6 \mathrm{~Kb}$ exprimiert wird. Es wurde Gesamt-RNA aus kultivierten Sertoli- und Leydigzellen mit der HASH-cDNA H-800 hybridisiert (Daten nicht gezeigt). Nur das große Transkript von $2.6 \mathrm{~Kb}$ wurde in beiden getesteten Zelltypen nachgewiesen. Ein bekanntes Gen, welches ein ähnliches Expressionsmuster wie das HASH-Gen zeigt, ist das c-kit-Proto-Onkogen, das für einen Transmembranprotein-Rezeptor kodiert (Sorrentino et al., 1991). Im Northern-Blot erhält man drei Transkripte der Größen von 5.5 Kb, 3.5 Kb und 2.3 Kb. Das 5.5 Kb große Transkript (c-kit) wird in ES-Zellen (embryonale Stammzellen) und in Sertolizellen wie auch in den prämeiotischen Stadien der Spermatogenese exprimiert. Die $3.5 \mathrm{~Kb}$ und $2.3 \mathrm{~Kb}$ c-kit Transkripte konnten nur in haploiden Keimzellen nachgewiesen werden. Dieses Gen 
spielt also eine wichtige Rolle nicht nur in der embryonalen, sondern auch in der postnatalen Testisentwicklung (Yoshinaga et al., 1991).

Der Vergleich der HASH-cDNA-Sequenz der Maus mit den in der Datenbank vorhandenen EST-Sequenzen aus embryonalen Stadien ergab eine beachtliche Übereinstimmung (Tab. 5). Daher wurde die Expression des HASH-Gens während der embryonalen Entwicklung der Maus untersucht. Mittels RT-PCR ließ sich die Expression des HASH-Gens in Blastocysten, 8.5-, 9.5-, 10.5-, 11.5- und 12.5-Tage alten Embryonen nachweisen (Abb. 4). Bei 13.5-Tage alten Embryonen wurde noch ein schwaches Signal detektiert, während bei 14.5-Tage alten Embryonen kein Signal mehr zu erhalten war. Um $\mathrm{zu}$ analysieren, wo genau das HASH-Gen im Embryo exprimiert wird, wurde die 'whole mount'- in situ-Hybridisierung mit 9.5- und 10.5-Tage alten Embryonen durchgeführt (Abb. 5). Hierbei wurden Hybridisierungssignale hauptsächlich im Neuralrohr und in Somiten bei 9.5- und 10.5-Tage alten Embryonalstadien beobachtet. Bei 10.5-Tage alten Embryonen war das Signal spezifisch nur in der distalen Region der Beinknospe zu beobachten. Im Sagitalschnitt von 9.5- und 10.5-Tage alten Embryonen wurde das ganze Neuralrohr von kaudal bis rostral hybridisiert. Mit einer Vergrößerung in Querschnitt wurde beobachtet, daß sich das Hybridisierungssignal deutlich auf den dorsalen Bereich des Neuralrohrs und auf den distalen Bereich der Beinknospe beschränkt. Weiterhin zeigte sich ein schwaches Hybridisierungssignal im Notochord.

Die Segregation von Zellen in ganz unterschiedliche Differenzierungswege ist essentiell für die Morphogenese in der frühen embryonalen Entwicklung (Übersicht bei Le Douarin und Kalcheim, 1999). Ein Beispiel für einen solchen morphologischen Differenzierungsprozess ist die Segregation der Neuralleistenzellen vom Neuralrohr. Die Vorläufer der Neuralleistenzellen entstehen aus dem Neuroepithel (Ektoderm), das die Spitze der Neuralfalte bildet. Während und nach Schließen der Neuralfalte entstehen die Neuralleistenzellen aus der sog. 'roof plate'-Region des Neuralrohrs. Aus Neuralleistenzellen differenzieren sich eine Vielzahl von verschiedenen Zelltypen, z. B. Nervenzellen des peripheren Nervensystems, Zellen des Binde- und Fettgewebes, Hautzellen, Melanozyten, endokrine Zellen (Le Douarin und Kalcheim, 1999). Einige Gene, z.B. Pax3 (Tremblay, et al., 1995), slug (Nieto et al., 1994), AP-2 (Zhang et al., 1996; Schorle et al., 1996), Wnt-1/3a (Ikeya et al., 1997), N-Cadherin (Hatta und Takeichi, 1986) und cad-7 (Nakagawa and Takeichi, 1995) sind spezifisch im dorsalen Bereich des Neuralrohrs exprimiert und ihre 
Translationsprodukte sind in die Generierung der Neuralleistenzellen involviert. Das Expressionsmuster des HASH-Gens in 9.5- und 10.5-Tagen alten Embryonen könnte darauf hinweisen, daß das HASH-Gen der Maus eine Rolle bei der Spezifizierung und Differenzierung der Neuralleistenzellen des dorsalen Neuralrohrs spielen könnte.

\section{Charakterisierung putativer Promotoren im HASH-Gen}

Bei der Ratte wurden insgesamt acht genomische Phagen-Klone des HASH-Gens, die 12 Exons enthalten, isoliert und charakterisiert (Aho, 1997). Die Restriktionskartierung der genomischen Fragmente der Phagen-Klone ergab, daß das HASH-Gen der Ratte sich über eine Länge von mehr als $100 \mathrm{~Kb}$ erstreckt. Durch Sequenzierung wurden alle Exon-IntronÜbergänge identifiziert. Dabei folgen alle Exon-Intron-Übergänge des HASH-Gens der Ratte der „GT-AG“-Regel (Breathnach und Chambon, 1981). Alle Introns beginnen mit den Nukleotiden GT in der 'splicing donor'-Sequenz und enden mit den Nukleotiden AG in der 'splicing acceptor'-Sequenz. Außerdem haben alle Spleißstellen eine hohe Homologie $\mathrm{zu}$ den von Breathnach und Chambon für Spleißstellen der proteinkodierenden Gene der Eukaryonten ermittelten Konsensussequenz.

Bei der Maus wurden im Rahmen dieser Arbeit ein genomischer Phagen-Klon und zwei genomische Cosmidklone isoliert und charakterisiert (Abschnitt III.3). Die Ergebnisse der RT-PCR-Experimente und der Northern-Blot-Hybridisierungen mit verschiedenen Exonspezifischen Fragmenten (Abschnitt III.2.2.) weisen darauf hin, daß jedes der drei HASHTranskripte durch einen eigenen Promotor charakterisiert ist (Abb. 15 und 33). Um die einen putativen Promotor für jedes Transkript des HASH-Gens enthaltenden genomischen Klone $\mathrm{zu}$ isolieren, wurde eine genomische Cosmidbank mit den cDNA-Fragmenten E1, E2 und E8 gescreent. Mit E1 und E8 wurde jeweils ein genomischer Cosmid-Klon (Hcos-B und HcosD) isoliert, während die Hybridisierung mit der Sonde E2 zu unspezifischen Signalen führte, die auf den sehr hohen GC-Gehalt (87\%) in der Sequenz des E2-Fragmentes zurückzuführen sind. Durch die Restriktionskartierung und Southern-Blot-Analyse wurde festgestellt, daß der genomische Cosmidklon Hcos-B nur Exon 1 enthält, während Hcos-D zwei Exons (Exon 8A und Exon 8) enthält. Das HASH-Gen der Maus in den drei genomischen Klonen, die nur 
5 Exons von 14 enthalten, erstreckt sich über eine Länge von $70 \mathrm{~Kb}$. Alle Exon-IntronÜbergänge des HASH-Gens in den drei genomischen Klonen folgen der „GT-AG“-Regel (Breathnach und Chambon, 1981).

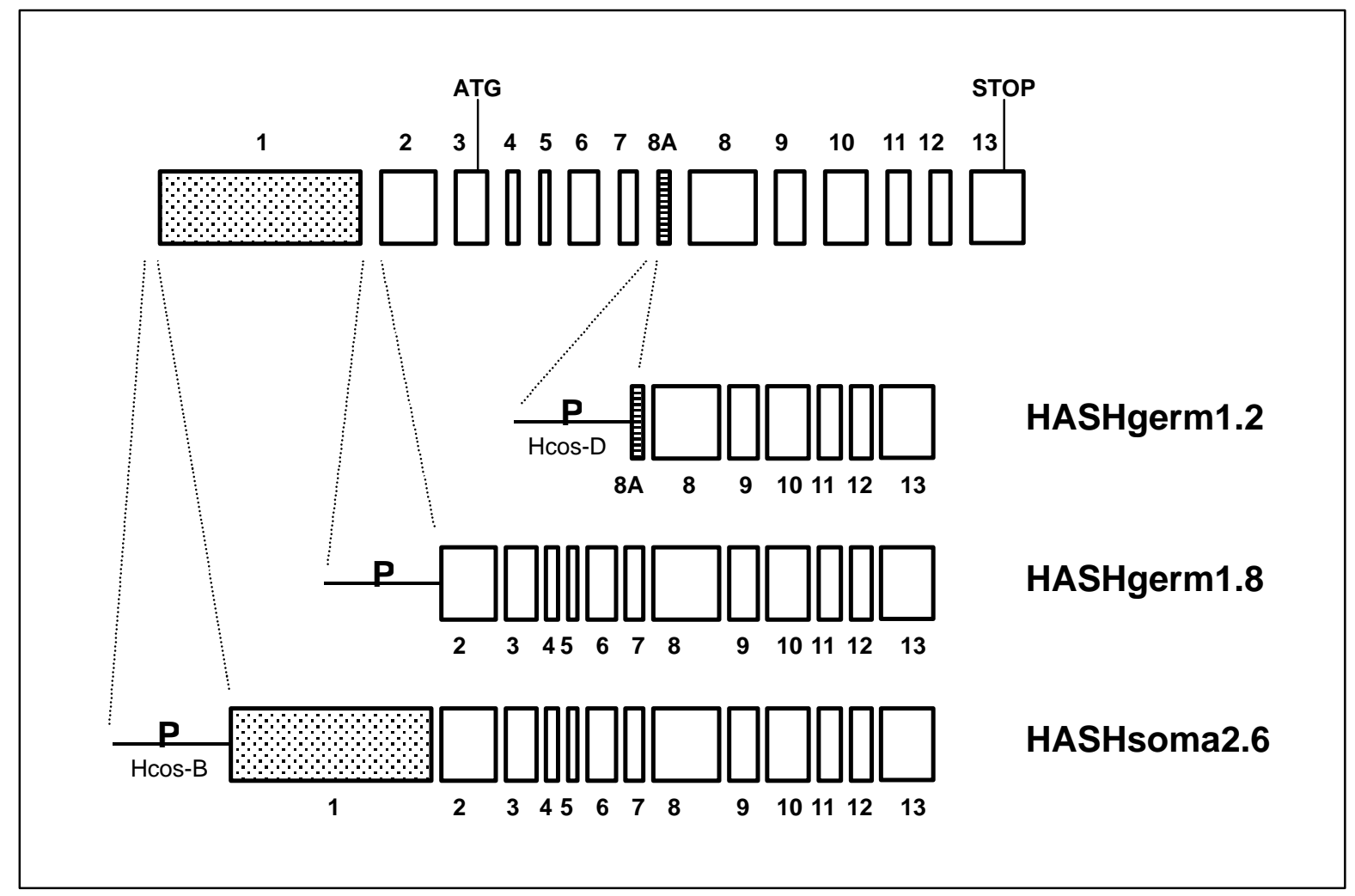

Abb. 33: Schematische Darstellung der Lokalisierung der putativen Promoterregionen der drei HASHTranskripte.

Die Ergebnisse der RT-PCR-Experimente und der Northern-Blot-Hybridisierungen mit verschiedenen Exon-spezifischen Fragmenten weisen darauf hin, daß jedes der drei HASHTranskripte durch einen eigenen Promotor charakterisiert ist. $P=$ putative Promotorregion. 
Konstitutive Promotorelemente, die die Initiation und Aktivierung der Trankription vermitteln, sind bei vielen eukaryotischen Genen in einem Bereich 5'-wärts des Transkriptionsstartpunktes zu finden (Lewin, 1990). Zur Charakterisierung der cisständigen Elemente, die an der Regulation der Expression des HASH-Gens beteiligt sein können, wurde ein ca. 800 Bp großer 5'-flankierender Bereich der beiden genomischen Cosmidklone (Hcos-B, Hcos-D) ab dem 5'-Ende des Exons 1 bzw. des Exons 8A (Abb. 7) sequenziert und hinsichtlich putativer cis-ständiger Sequenzen mit Hilfe des Computerprogramms „MatInspector“ (Quandt et al. 1995) untersucht. In beiden Sequenzen wurde keine TATA-Box im konventionellen Abstand von -25 bis -35 Nukleotiden gefunden. TATA-Box-lose Promotoren sind für viele eukaryotische Gene beschrieben worden (Goodrich et al., 1996). Ein weiteres ubiquitär vorkommendes Promotorelement stellt die CCAAT-Box dar, die sich in der Regel ca. -75 Nukleotiden vom Transkriptionsstartpunkt befindet (Maity and de Crombrugghe, 1998). Es konnte in beiden Sequenzen keine CCAATBox gefunden werden.

In der 5'-flankierenden Sequenz des HASH-Gens im Cosmidklon Hcos-B wurden mehrere cis-ständige Elemente für die zwei trans-Faktoren (Transkriptionsfaktoren) Nkx 2.5 und GATA gefunden. An den Positionen -281, -371, -596 und -608 kann eine Sequenz für die Bindung des Transkriptionsfaktors Nkx2.5 gefunden werden (Abb. 34, A). Nkx2.5 wurde ursprünglich bei Drosophila isoliert und als tinman bezeichnet (Bodmer, 1993). Nkx2 Gene in Wirbeltieren kodieren eine Subfamilie der Homeodomäne-enthaltenden Transkriptionsfaktoren, die für die Morphogenese und die Zelldifferenzierung während der Embryogenese (Evans et al., 1995; Newman and Krieg, 1998; Tanaka et al., 1998; Tonissen et al., 1994) eine wichtige Rolle spielen. In Embryonen der Maus sind einige Nkx2 Gene im ventralen Bereich des Neuroektoderms und im Neuralrohr exprimiert, während andere Nkx2 Gene vor allem im Mesendoderm und in den sich daraus entwickelnden Organen wie Herz und Darm exprimiert sind (Harvey, 1996; Pabst et al., 2000). An den Positionen -543 und -683 liegt eine homologe Sequenz für die Bindung des Transkriptionsfaktor GATA (Abb. 34, B). Die GATA-Familie kodiert einen Zinkfingerenthaltenden Transkriptionsfaktor, der die Zelltyp-spezifische Transkription reguliert (Jiang and Evans, 1996; Kelly et al., 1993). In der letzten Zeit wurde bekannt, daß GATA-2 und GATA-3 in den sehr frühen Stadien der Embryonalentwicklung im Zentralnervensystem exprimiert sind (George et al., 1994; Nardelli et al., 1999). Es wurde auch gezeigt, daß bei GATA-2 ${ }^{-/}$-Mäusen die embryonale Neurogenese stark gestört ist (Tsai et al., 1994). Die 
anderen Mitglieder der GATA-Familie, GATA-4/5/6 sind an der Herz-Organogenese (Laverriere et al., 1994) beteiligt.

A. cis-Elemente für den Nkx2.5-Transkriptionsfaktor

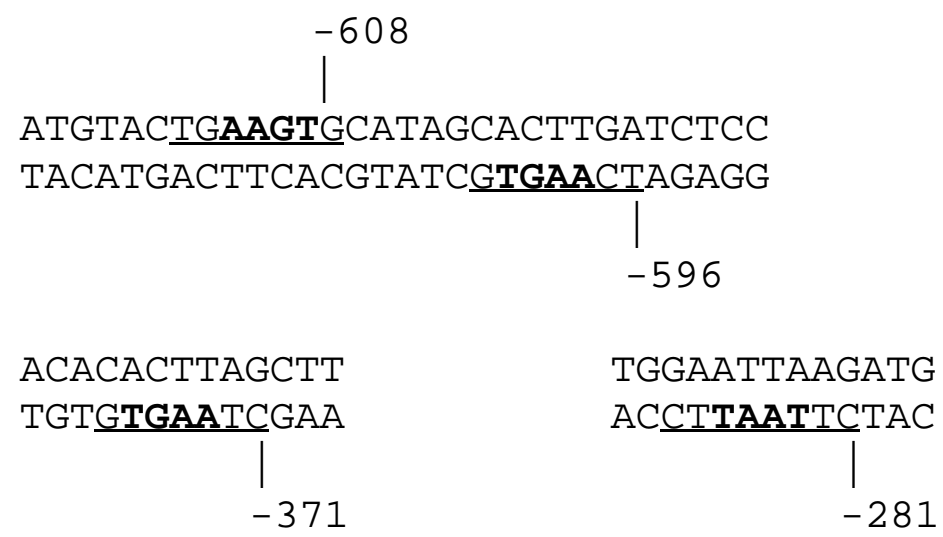

B. cis-Elemente für den GATA-Transkriptionsfaktor
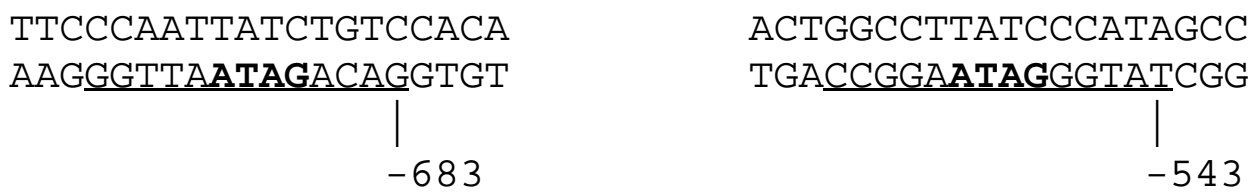

Abb. 34: Putative cis-ständige Elemente für den Transkriptionsfaktor Nkx2.5 (A) und GATA (B) in der Promotorregion für das 2.6 Kb HASH-Transkript.

cis-Elemente sind unterstrichen und 'core'-Sequenzen sind fett geschrieben.

Interessanterweise wurde von Jiang et al. (1996) beschrieben, daß durch die Interaktion zwischen GATA-4/5/6- und Nkx2.5-Transkriptionsfaktoren die Differenzierung des Myokards reguliert wird. Aufgrund dieses Befundes könnte vermutet werden, daß beim HASH-Gen der Maus ähnliche regulatorische Interaktionen zwischen GATA- und Nkx2Transkriptionsfaktoren in den cis-Elementen stattfinden. Die spezifische Expression des HASH-Gens im dorsalen Bereich des Neuralrohrs bei der embryonalen Entwicklung (Abb. 5) könnte durch das Zusammenspiel mit den GATA- und Nkx-Transkriptionsfaktoren reguliert werden. 
Aus Untersuchungen bei einigen testisspezifisch exprimierten Genen wurde vermutet, daß die Transkriptionskontrolle für die Regulation der testisspezifischen Expression eine wichtige Rolle spielen muß (Hecht, 1998). Für die Regulation der Genexpression spielen Interaktionen zwischen Transkriptionfaktoren (trans-Elemente) und Sequenzen im Promotorbereich der Gene (cis-Elemente) eine entscheidende Rolle (Engel et al., 1992). Die 5'-flankierende Region des HASH-Gens im Cosmidklon Hcos-D, das den testisspezifischen Promotor für das kleine, testisspezifisch exprimierte HASH-Transkript von $1.2 \mathrm{~Kb}$ besitzen sollte, sollten Informationen bezüglich der Transkriptionsfaktoren und möglichen Kofaktoren geben, die an der Modulation und Regulation der Expression des 1.2 Kb HASH-Transkriptes beteiligt sind. In der 5'-flankierenden Sequenz des HASH-Gens im Cosmidklon Hcos-D sind mehrere putative cis-ständige Elemente für den Transkriptionsfaktor AP-1 nachweisbar. An den Positionen -102, -178, und -454 liegt eine homologe Sequenz für die Bindung des Transkriptionsfaktor AP-1 (Abb. 35). Nach Cohen et al. (1993) könnte der Transkriptionsfaktor-Komplex AP1, der aus mehreren Komponenten, z.B. c-fos, fra-1, fra-2 c-jun und junB besteht, eine Rolle bei der transkriptionellen Regulation in verschiedenen Stadien der Spermatogenese spielen.
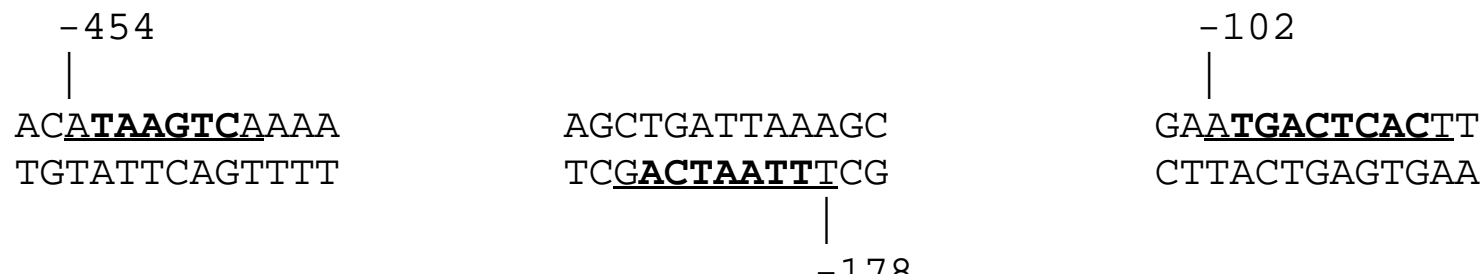

$-178$

Abb. 35: Putative cis-ständige Elemente für den Transkriptionsfaktor AP-1 in der Promotorregion für das 1.2 Kb HASH-Transkript.

cis-Elemente sind unterstrichen und 'core'-Sequenzen sind fett geschrieben. 


\section{Chromosomale Lokalisation des HASH-Gens des Menschen}

Mit Hilfe der FISH (Fluoreszenz-in situ-Hybridisierung)-Methode wurde das HASH-Gen der Ratte auf Chromosom 5q34-35 lokalisiert (Aho, 1997). Auf Chromosom 5 der Ratte sind bislang 14 Gene lokalisiert worden (http://www.il-st-acad-sci.org/genecats/rno05.html; Truett et al., 1995). Die meisten Gene in dieser Region sind als Kopplungsgruppe auf Chromosom 4 der Maus lokalisiert. Es wird angenommen, daß die Gene auf Chromosom 5 der Ratte eine syntäne Gruppe auf Chromosom 4 der Maus darstellen. Diese Gene wurden beim Mensch während der Evolution auf drei Chromosomenabschnitte verteilt: 1p32, 8q11 und 9p22-q32 (Yamada et al., 1994). In der Nähe des HASH-Lokus (5q34-35) bei der Ratte ist das Gen für einen Glukosetransporter (GLUT1) lokalisiert. Beim Menschen ist das GLUT1 Gen auf Chromosom 1p32 lokalisiert. Daher vermutet, daß das HASH-Gen beim Menschen ebenfalls auf Chromosom 1p32 lokalisiert ist. Um diese Vermutung zu bestätigen, wurde eine FISH-Analyse mit einem genomischen humanen P1-Klon durchgeführt, der mit Hilfe der HASH-cDNA der Maus aus einer humanen P1-Bibliothek isoliert wurde. Die Kartierung mittels FISH zeigte, daß das menschliche HASH-Gen auf Chromosom 1 (Region p31-35) lokalisiert ist (Abb. 22). In dieser Region beim Menschen sind bislang etwa 200 Gene lokalisiert worden (OMIM; Online Mendelian Inheritance in Man).

\section{Alternatives Spleißen der HASH-mRNAs}

In Testis-RNA der Maus konnten in Northern-Blot-Analysen drei HASH-Transkripte von 2.6 $\mathrm{Kb}, 1.8 \mathrm{~Kb}$ und $1.2 \mathrm{~Kb}$ nachgewiesen werden (Abb. 1). Anhand von Southern-Blot-Analysen wurde festgestellt, daß nur eine Kopie des HASH-Gens im Genom der Maus vorhanden ist (Aho, 1997). Daher wurde davon ausgegangen, daß die drei Transkripte des HASH-Gens durch alternatives Spleißen zustandekommen.

Bei der Gewebedifferenzierung ist die Synthese verschiedener Proteine in unterschiedlichen Zelltypen zu definierten Zeitpunkten der Entwicklung wichtig. In Bakterien kann die differentielle Genexpression auf den Ebenen der Transkription und der Translation beeinflußt 
werden. Bei Eukaryonten gibt es zusätzlich die Möglichkeit der Regulation auf der Ebene des RNA-'processing'. Alternatives Spleißen spielt dabei eine wichtige Rolle für die Synthese verschiedener Proteine (Breitbart und Nadal-Ginard, 1987; Shen et al., 1991; Mettus et al., 1994). Es wurden mehrere Möglichkeiten für alternatives Spleißen genannt (Smith et al., 1989), z.B. alternative Promotoren, alternative Poly(A)-Signale oder alternatives Exon-Spleißen. Um zu klären, wie drei HASH-Transkripte entstehen, wurden RT-PCR- und Northern-Blot-Analysen bei der Maus durchgeführt.

In der 3'-flankierenden Region des HASH-Gens der Ratte wurde ein zweites Polyadenylierungssignal (AATAAA), das vom ersten Polyadenylierungssignal (ATGAAA) $705 \mathrm{Bp}$ entfernt ist, identifiziert. Das Vorhandensein der zwei Polyadenylierungssignale führte zur Annahme, daß die unterschiedlichen HASH-mRNAs auf die Nutzung der beiden Polyadenylierungssignale zurückzuführen sind. In der Literatur gibt es Beispiele für Gene, die mehrere Polyadenylierungssignale besitzen. Als Beispiele für solche Gene können die Gene für alpha- und beta-Tropomyosin genannt werden (Medford et al., 1984; Helfman et al., 1986). Um unsere Annahme zu überprüfen, wurde zuerst das cDNA-Fragment zwischen den beiden Poly(A)-Signalen durch RT-PCR amplifiziert und anschließend für die Northern-BlotAnalyse verwendet. Dabei konnte kein Signal detektiert werden, so daß davon auszugehen war, daß die Sequenz zwischen den zwei Polyadenylierungssignalen der Maus nicht transkribiert wird und in keinem Zusammenhang mit einem alternativen Spleißen der HASHmRNA steht. Um zu überprüfen, ob die drei HASH-Transkripte durch ein internes, alternatives Spleißen entstehen, wurden RT-PCR-Experimente mit verschiedenen Exonspezifischen Primern durchgeführt. Trotz mehrmaliger Versuche wurde kein alternatives Spleißprodukt gefunden. Diese Ergebnisse weisen darauf hin, daß die Gewebespezifität und Phasenspezifität der HASH-Transkripte mit unterschiedlichen Promotoren im Zusammenhang stehen können.

Aus den Ergebnissen der Northern-Blot-Hybridisierung mit verschiedenen Exon-spezifischen Fragmenten konnte festgestellt werden, daß die drei HASH-Transkripte sich nur im 5'Bereich unterscheiden. Dieser Befund führte $\mathrm{zu}$ der Annahme, daß das HASH-Gen verschiedene Promotoren besitzt, die die Transkription der verschiedenen mRNAs spezifisch in den unterschiedlichen Zellen regulieren. Die Funktion multipler Promotoren liegt darin, daß sie in verschiedenen Zellen aktiviert werden. Bei anderen Genen wurden bereits multiple Promotoren beschrieben. Für das homöotische Gen Antennapedia, das in der 
frühen Entwicklung bei Drosophila eine wichtige Rolle spielt, konnten zwei Promotoren und zwei Transkriptionsstartpunkte identifiziert werden (Frischer et al., 1986; Kaufmann et al., 1990). Das Transkript vom ersten Promotor ist in diesem Fall wichtig für die Entwicklung des dorsalen Thorax, während das Transkript vom zweiten Promotor für die Entwicklung des ventralen Thorax entscheidend ist (Frischer et al., 1986).

Zusammenfassend führen die Ergebnisse zu der Schlußfolgerung, daß sich die drei HASHmRNAs im 5'-Bereich voneinander unterscheiden und im HASH-Gen mehrere Promotoren und Transkriptionsstartpunkte realisiert sind.

\section{Versuch zur Herstellung von HASH ${ }^{-/}$-Knock out-Mäusen}

Die moderne Mausgenetik verfügt über eine potente Methode für die funktionelle Analyse von Genen, die sogenannt „Knock out“-Methode (Capecchi, 1989). Unter „Knock out“ versteht man die funktionelle Deletion (Nullmutation) eines Gens, die durch die homologe Rekombination in ES-Zellen ermöglicht werden kann. Um die Funktion des HASH-Gens der Maus zu studieren, wurde in der vorliegenden Arbeit versucht, das HASHGen der Maus mit Hilfe der homologen Rekombination zu inaktivieren. Die partielle Deletion im HASH-Gen sollte den ATG-Kodon enthaltenden Bereich betreffen, so daß sichergestellt wird, daß nach erfolgter Rekombination kein funktionelles HASH-Protein mehr entstehen kann. Die Inaktivierung des Gens in den ES-Zellen sollte mit Hilfe eines TargetingVektors vom Replacement-Typ erfolgen, d.h. die endogenen Sequenzen im nativen Allel werden gegen speziesfremde DNA-Segmente durch 'crossing over' in homologen Sequenzen ausgetauscht (Abb. 24). Nach Elektroporation des Targeting-Vektors in ES-Zellen und nach entsprechender Selektion wurden vier ES-Zell Klone (\#9, \#31, \#67 und \#71) durch die Hybridisierung mit der 5'-externen Sonde als homologe Rekombinanten identifiziert (Abb. 26A). Die Rehybridisierung mit der Neomycin-Sonde zeigte bei den ES-Zellklonen \#31 und \#71 ein erwartetes Signal mit einer Größe von $2.4 \mathrm{~Kb}$, während sich bei dem ES-Zellklon \#9 ein unerwartetes Hybridisierungssignal mit einer Größe von $1.8 \mathrm{~Kb}$ zeigte (Abb. 26B). Dieses $1.8 \mathrm{~Kb}$ große Hybridisierungsfragment mit der Neomycin-Sonde kann nicht als „RandomIntegration“ betrachtet werden, weil die Hybridisierung mit der 5'-externen Sonde zeigte, daß 
der ES-Zell Klon \#9 im Lokus des HASH-Gens homolog rekombiniert ist. Eine externe Probe außerhalb des Konstruktes diente zur Bestätigung der homologen Rekombination. Der ES-Zellklon \#67 zeigte sowohl ein erwartetes Signal mit einer Größe von $2.4 \mathrm{~Kb}$ als auch ein unerwartetes Signal mit einer Größe von 1.8 Kb. Zur Herstellung der Chimären wurden die ES-Zellklone \#31 und \#71 für die Aggregation bzw. Blastocysten-Injektion verwendet. Trotz mehrmaliger Versuche wurden keine Chimären erhalten. Daher wurde dann der ESZellklon \#67 für die Blastocysten-Injektion eingesetzt. Es wurde davon ausgegangen, daß die zusätzliche Integration des Neomycin-Gens im ES-Zellklon \#67 durch die Verpaarung der Mäuse segregiert werden kann. Von den insgesamt neun erzeugten Chimären mit dem ESZellklon \#67 transmittierten zwei männliche Tiere die Mutation durch die Keimbahn (Tab. 1). Bei +/- heterozygoten Mäusen der F1-Generation wurden keinerlei Auffälligkeit gefunden. Bei der Genotypisierung der F2-NMRI-Mäuse mit Hilfe der PCR wurde keine einzige -/homozygote Maus gefunden (Tab. 2). Daraus wurde gefolgert, daß HASH-defiziente Mäuse während der embryonalen Entwicklung absterben. Die embryonale Lethalität der $\mathrm{HASH}^{-{ }^{-}}$Mäuse schien mit dem Expressionsmuster des HASH-Gens in der embryonalen Entwicklung gut korreliert zu sein. Bei der weiteren Untersuchung embryonaler Stadien wurde eine Abnormalität im Kopf bei drei von zwölf Embryonen beobachtet. Besonders der Bereich des Prosencephalons war stark reduziert. Um zu bestätigen, daß diese Abnormalität des Kopfes als Folge der Deletion des HASH-Allels anzusehen ist, wurde die Genotypisierung der betroffenen Embryonen mit Hilfe der PCR durchgeführt. Überraschendeweise wurden die Embryonen mit dieser Kopfabnormalität als Heterozygote identifiziert. Um das Ergebnis der Genotypisierung durch PCR zu überprüfen, wurde dann eine Southern-Blot-Analyse mit den oben genannten 12 Embryonen durchgeführt. Die Hybridisierung mit der externen Probe (5H-P) zeigte, daß vier der 12 Embryonen Homozygote waren (Abb. 28). Die Embryonen, die eine Abnormalität im Bereich des Kopfes zeigten und mittels PCR als heterozygot identifiziert worden waren, wurden jedoch nach Southern-Blot-Hybridisierung als homozygot klassifiziert. Ferner wurde ein Embryo, der morphologisch keine Abnormalität zeigte, auch als homozygot identifiziert. 


\subsection{Insertion des Konstruktes innerhalb des $5^{\prime}$-flankierenden Bereiches}

Zur Erklärung der unterschiedlichen Ergebnisse der Genotypisierung mittels PCR und Southern-Blot-Hybridisierung wurden weitere Untersuchungen durchgeführt. Für die genaue Charakterisierung war eine Rehybridisierung mit einer internen Sonde notwendig, obwohl die homologe Rekombination durch 'crossing over' in den ursprünglichen ES-Zellen mit der externen Sonde bestätigt worden war. Bei der Rehybridisierung mit der internen Sonde wurde das Wildtyp-Allel des HASH-Gens mit einer Größe von $17 \mathrm{~Kb}$ und das Mutante-Allel mit einer Größe von $10 \mathrm{~Kb}$ detektiert, obwohl mit dem mutierten Allel keine Hybridisierung vorkommen darf. Dieses Ergebnis weist darauf hin, daß bei diesen Mäusen keine partielle Deletion des HASH-Gens durch die homologe Rekombination vorhanden ist. Aus allen Daten der Southern-BlotHybridisierungen wurde eine mögliche Erklärung für die unterschiedlichen Ergebnisse bei der PCR und bei der Southern-Blot-Hybridisierung abgeleitet. Normalerweise findet der Genaustausch zur Inaktivierung des betreffenden Gens durch die homologe Rekombination statt, die durch 'crossing over' in den 5'- und 3'-flankierenden Bereichen vermittelt wird. Es kann angenommen werden, daß statt der homologen Rekombination in den 5'- und 3'flankierenden Bereichen eine Integration des vollständigen oder partiellen Konstruktes innerhalb der 5'-flankierenden Region stattgefunden hat (Abb. 36). 


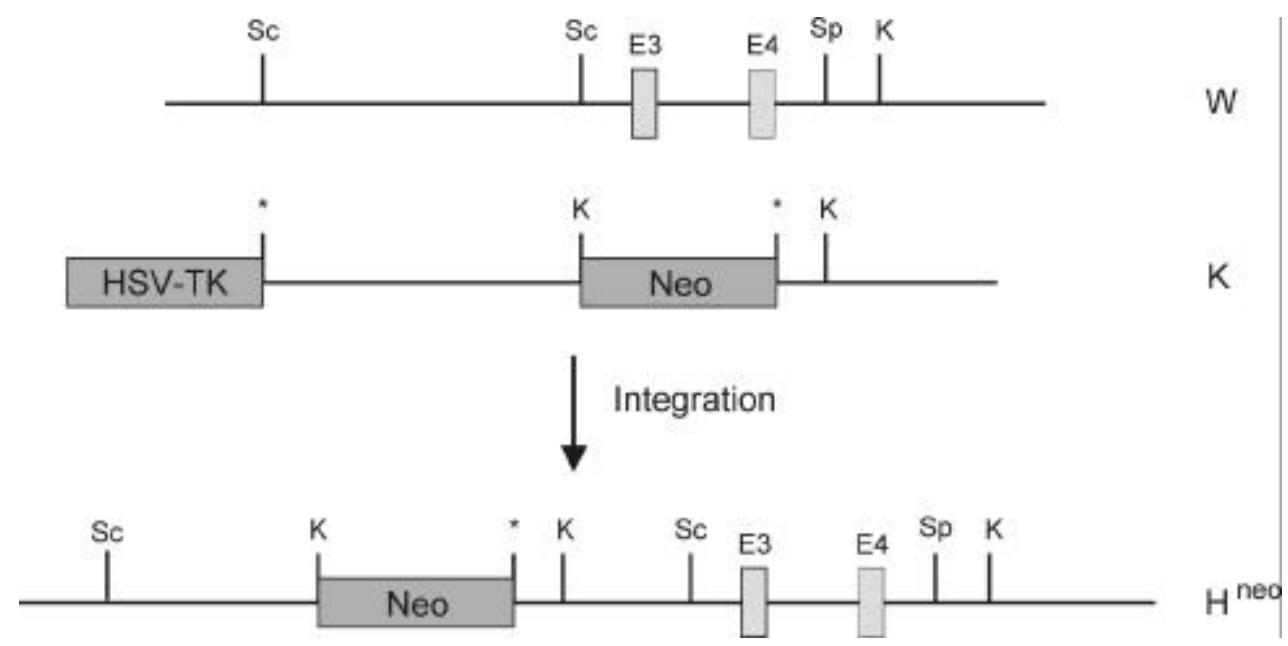

Abb. 36: Schematische Darstellung der Insertion des Konstruktes.

Durch eine Integration des vollständigen oder partiellen Konstruktes innerhalb der 5'flankierenden Region statt der homologen Rekombination in den 5'- und 3'-flankierenden Bereichen ergibt sich das $\mathrm{HASH}^{\text {neo }}$-Insertionsallel.

$W=$ Wildtyp-Allel; $K=$ Konstrukt; $H^{\text {neo }}=H A S H^{\text {neo }}$-Insertionsallel

Eine ähnliche Beobachtung wurde von einer Gruppe in Kanada im Jahr 1992 beschrieben (Moens et al., 1992). Für die funktionelle Analyse des N-myc Gens versuchte diese Gruppe ein Allel des Gens N-myc durch die homologe Rekombination in ES-Zellen zu inaktivieren. Dabei wurden 4 homolog-rekombinierte ES-Zellen durch Southern-Blot-Hybridisierung mit der 5'-externen Sonde und mit der Neomycin-Sonde und durch PCR-Analyse identifiziert. Von diesen ES-Zellklonen zeigte nur ein ES-Zellklon mit dem rekombinierten Allel eine Keimbahntransmission. Durch die nachfolgende Southern-Blot-Hybridisierung mit einer internen Sonde wurde jedoch festgestellt, daß das N-myc Gen in diesem ES-Zellklon nicht deletiert war. Weitere Southern-Blot-Hybridisierungen ergaben, daß wie in unserem ESZellklon \#67 der größte Teil des Targeting-Vektors im Intron der 5'flankierenden Region inseriert war. 
Eine Erklärungsmöglichkeit für diese Insertionsrekombination ist, daß der linearisierte Targeting-Vektor nach der Elektroporation teilweise degradiert, in ES-Zellen wieder rezirkularisiert und durch die 'single insertion-type recombination' zwischen dem endogenen Bereich und der homologen Region des Targeting-Vektors integriert wird (Abb. 37, B). Es ist auch möglich, daß der Targeting-Vektor vor der Integration in die ES-Zellen concatamerisiert wird und ein Concatamer entsteht, das an beiden Enden die 5'-flankierende Region enthält. Dann findet die homologe Rekombination zwischen dem endogenen Bereich und der flankierenden Region des Concatamers statt (Abb. 37, A). Die Southern-Blot-Hybridisierung der DNA des ES-Zellklons \#67 mit der Neomycin-Sonde zeigt (Abb. 24B), daß das unerwartete Signal von $1.8 \mathrm{~Kb}$ als Ergebnis der Concatamerisierung anzusehen ist. Ohne Rücksicht auf den möglichen Mechanismen, ist die Insertionsrekombination sehr selten (Hasty et al. 1991).

\section{A. Concatamerisierung $\quad$ B. Rezirkularisierung}

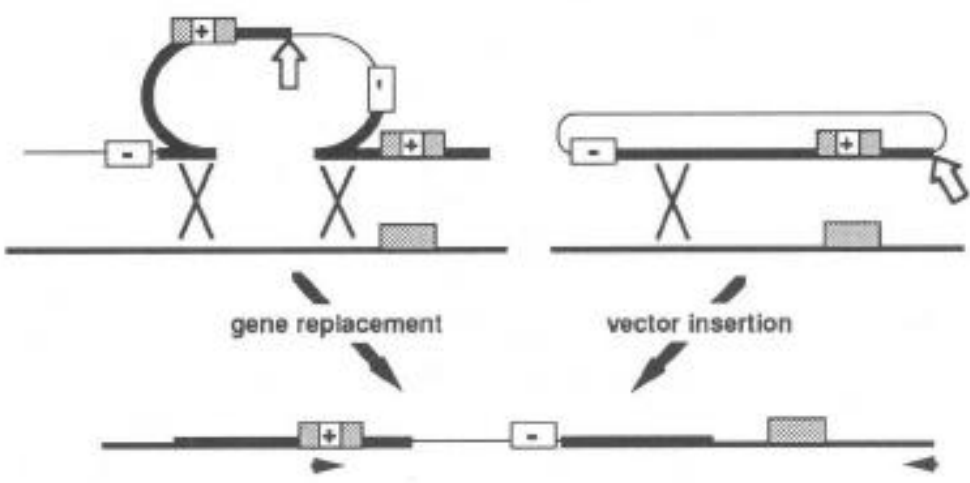

Abb. 37: Schematische Darstellung von Integrationsmöglichkeit des Targeting-Vektors.

A. Der Targeting-Vektor wird vor der Integration in die ES-Zellen concatamerisiert, und es entsteht ein Concatamer, das an beiden Enden die 5'-flankierende Region enthält. Dann findet die homologe Rekombination zwischen dem endogenen Bereich und der flankierenden Region des Concatamers statt.

B. Der linearisierte Targeting-Vektor wird in ES-Zellen wieder rezirkularisiert und durch die 'single insertion-type recombination' zwischen dem endogenen Bereich und der homologen Region des Targeting-Vektors integriert. 


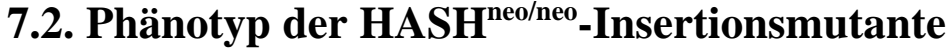

Alle geborene $\mathrm{HASH}^{\text {neo/neo }}-$ Nachkommen waren nach der Geburt lebensfähig und zeigten keine äußerlich erkennbaren Abnormalitäten oder Veränderung in Kopf- und Körpergröße. Ebenso zeigten alle Tiere ein normales Paarungsverhalten. In Tabelle 8 ist die quantitative Verteilung der durch die Southern-Blot-Hybridisierung genotypisierten Nachkommen der F2-Generation (Hintergrund 129/SvJ und NMRI) dargestellt. Aus dem Vergleich der genotypisierten Nachkommen auf dem Hintergrund 129/SvJ mit denen auf dem Hintergrund NMRI (Tab. 8) ergibt sich; 1. daß die Lethalität bei 129/SvJ-Hintergrund viel größer ist als bei NMRI-Hintergrund, und 2. daß nicht alle $\mathrm{HASH}^{\text {neo/neo }}$-Mäuse während der embryonalen Entwicklung absterben. Diese Ergebnisse deuten darauf hin, daß im Bezug auf die embryonale Lethalität der genetische Hintergrund wichtig ist.

Tab. 8: Quantitative Verteilung von Wildtyp-, heterozygoten und homozygoten Mäusen in der F2Generation auf dem Hintergrund 129/SvJ (A) und auf dem Hintergrund NMRI (B).

A. Hintergrund $129 / \mathrm{SvJ}$

\begin{tabular}{c|c|c|c|c|c}
\hline \hline \multicolumn{2}{c|}{$+/+$} & \multicolumn{2}{|c|}{$+/-$} & \multicolumn{2}{c}{$-/-$} \\
\hline \multicolumn{2}{c|}{$12(34.3 \%)$} & \multicolumn{2}{|c|}{$20(57.1 \%)$} & \multicolumn{2}{|c}{$3(8.6 \%)$} \\
\hline Männchen & Weibchen & Männchen & Weibchen & Männchen & Weibchen \\
\hline 7 & 5 & 7 & 13 & 1 & 2 \\
\hline \hline
\end{tabular}

B. Hintergrund NMRI

\begin{tabular}{c|c|c|c|c|c}
\hline \hline \multicolumn{2}{c|}{$+/+$} & \multicolumn{2}{c|}{$+/-$} & \multicolumn{2}{c}{$-/-$} \\
\hline \multicolumn{2}{c|}{$31(32.0 \%)$} & \multicolumn{2}{c|}{$49(50.5 \%)$} & \multicolumn{2}{c}{$17(17.5 \%)$} \\
\hline Männchen & Weibchen & Männchen & Weibchen & Männchen & Weibchen \\
\hline $\mathrm{n}$ & $\mathrm{n}$ & 14 & 35 & 5 & 12 \\
\hline \hline
\end{tabular}

$\mathrm{n}=$ nicht analysiert 
Bei 10-Tage alten HASH ${ }^{\text {neo/neo }}$-Embryonen wurden Abnormalitäten des Kopfes (Öffnung des Neuralrohrs, Reduktion der Kopfgröße) beobachtet (Abb. 38). Besonders der Bereich des Prosencephalon war stark reduziert, wodurch das Vorderhirn abgeflacht erschien. Nach dem Schließen des Neuralrohrs ist die intensive Expansion des Prosencephalon-Ventrikels sehr charakteristisch für diese Stadien (Lee und Jessell, 1999; Rubenstein und Shimamura, 1998). Es kann daher vermutet werden, daß das HASH-Protein beim Verschluß oder bei der Proliferation des Neuralrohrs eine Rolle spielt. Kürzlich wurde ein den $\mathrm{HASH}^{\text {neo/neo }}$ Embryonen sehr ähnlicher Phänotyp bei den flat-top'-Embryonen beschrieben (Hentges et al. 1999). Bei der 'flat-top'-Mutation handelt es sich um eine chemisch induzierte Mutation. Bei den homozygoten Embryonen findet sich eine deutliche Reduktion des Prosencephalons, ebenfalls mit abgeflachten Vorderhirn. Interessanterweise wurde das 'flat-top'-Gen bei der Maus auf Chromosom 4 (ca. $76 \mathrm{cM}$ ) und beim Menschen auf Chromosom 1p35-36 lokalisiert. In dieser Region liegt aush das HASH-Gen. Es ist denkbar, daß das 'flat-top'-Gen und das HASH-Gen identisch sind.

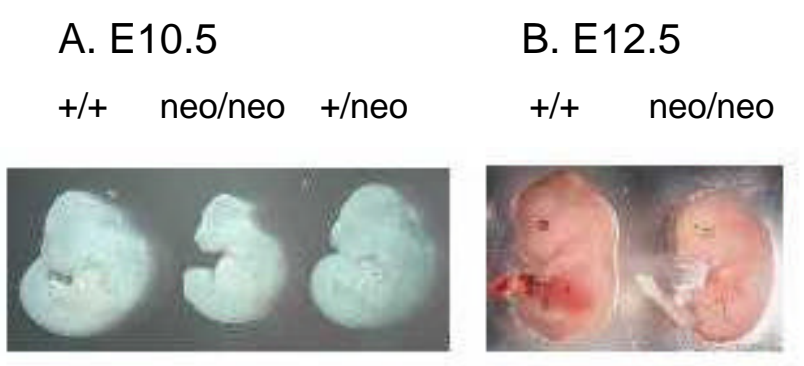

Abb. 38: Abnormalität des Kopfes der 10.5 (A)- und 12.5 (B)-Tage alten HASH ${ }^{\text {neo/neo }}$-Embryonen.

Besonders der Bereich des Prosencephalon ist stark reduziert, wodurch das Vorderhirn abgeflacht erscheint.

$+/+=$ Wildtyp; neo/neo $=H A S H^{\text {neo/neo }}$-Insertionsembryonen 


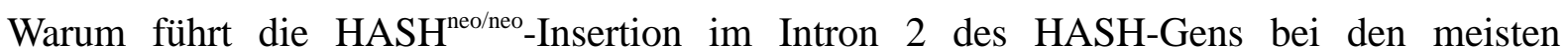
homozygoten auf dem Hintergrund 129/SvJ zu embryonaler Lethalität? Das Signalmolekül Sonic hedgehog (Shh) reguliert die verschiedene Differenzierungsprozesse während der Entwicklung bei Vertebraten (Echelard et al., 1993; Ekker et al., 1995). Die Ergebnisse vieler Experimente weisen darauf hin, daß die räumliche und zeitliche Expressionsregulation des Shh-Gens essentiell für das 'patterning' eines Embryos ist (Krauss et al., 1993; Johnson et al., 1994; Barth und Wilson, 1995). Kürzlich identifizierte die Gruppe von Strähle zwei Enhancer-Elemente (ar-A und ar-C) in Intron 1 und Intron 2 des Shh-Gens (Müller et al, 1999). Es wurde auch festgestellt, daß das Enhancer-Element ar-A in Intron1 bzw. das Enhancer-Element ar-C in Intron 2 die Expression von Shh im Notochord bzw. im 'floor plate' vermittelt, woraus geschlossen werden kann, daß die Enhancer-Elemente in den Intronen bei der zeitlichen und räumlichen Genexpression eine wichtige Rolle spielen. Daraus könnte die Spekulation ausgehen, daß das Intron 2 des HASH-Gens ein EnhancerElement für seine eigene Expression während der embryonalen Entwicklung enthält. 


\section{ZUSAMMENFASSUNG}

1. Mit Hilfe der Marathon-RACE-PCR konnte die gesamte HASH-cDNA der Maus ermittelt werden. Sie besteht aus 2678 Bp und beinhaltet einen offenen Leserahmen von 1290 Bp. Der 3'-nichttranslatierte Bereich enthält ein modifiziertes Polyadenylierungssignal, das $18 \mathrm{Bp}$ weit vom Poly(A)-Schwanz, der eine Länge von ca. 100 Nukleotiden besitzt, entfernt ist. Die Homologie der isolierten HASH-cDNA der Maus beträgt zu der der Ratte 97\% und zu den EST-Klonen des Menschen 88\%. Der Vergleich der HASH-cDNA und der daraus abgeleiteten Aminosäuresequenz mit den Nukleotid- bzw. Aminosäuresequenzen in den Datenbanken EMBL und GenBank ergibt keine signifikante Homologien zu bekannten Sequenzen.

2. Durch Northern-Blot-Analysen konnte nachgewiesen werden, daß das HASH-Gen im Testis der Maus exprimiert ist, und zwar mit drei Transkripten $(2.6 \mathrm{~Kb}, 1.8 \mathrm{~Kb}$ und 1.2 $\mathrm{Kb}$ ). Es konnte auch eine schwache Expression des 2.6 Kb Transkripts in Ovar, Placenta, Thymus und Gehirn nachgewiesen werden. Bei weiteren Expressionsuntersuchungen während der postnatalen Testisentwicklung konnte gezeigt werden, daß das 2.6 Kb HASHTranskript in der RNA von 5- bis 60-Tage alten Testes vorhanden ist, während die zwei kleineren HASH-Transkripte $(1.8 \mathrm{~Kb}$ und $1.2 \mathrm{~Kb})$ zum Zeitpunkt der ersten haploiden Differenzierungsstadien (Spermatiden) im Testis nachweisbar werden. Untersuchungen an Testis-RNA von verschiedenen Mausmutanten mit Keimzelldefekten ergaben, daß die zwei kleineren HASH-Transkripte $(1.8 \mathrm{~Kb}$ und $1.2 \mathrm{~Kb})$ erst in haploiden Keimzellen exprimiert werden, während das große Transkript $(2.6 \mathrm{~Kb})$ nur in somatischen Geweben nachweisbar ist.

3. Die Expression während der embryonalen Entwicklung wurde mithilfe der RT-PCRAnalyse an Gesamt-RNA aus Blastocysten, 8.5-, 9.5-, 10.5-, 11.5-, 12.5-, 13.5- und 14.5Tagen alten Embryonen analysiert. Transkripte des HASH-Gens ließen sich in Blastocysten, 8.5-, 9.5-, 10.5-, 11.5- und 12.5-Tagen alten Embryonen nachweisen. Bei 13.5-Tage alten Embryonen wurde ein schwaches Signal detektiert, während bei 14.5-Tage alten Embryonen kein Signal mehr erhalten wurde. Mit Hilfe der 'whole mount'- in situHybridisierung konnte nachgewiesen werden, daß das HASH-Gen hauptsächlich im Neuralrohr und in den Somiten bei 9.5- und 10.5-Tage alten Embryonen exprimiert ist. In 
Sagitalschnitten wurde die Expression nur im dorsalen Neuralrohr von kaudal bis rostral beobachtet.

4. Aus den Ergebnissen der RT-PCR-Experimente mit verschiedenen Exon-spezifischen Primern und der Northern-Blot-Hybridisierungen mit verschiedenen Exon-spezifischen Fragmenten konnte gezeigt werden, daß die drei HASH-Transkripte durch drei verschiedene Promotoren zustandekommen.

5. Ein polyklonaler Antikörper wurde mit einem aus der cDNA abgeleiteten HASH-Peptid hergestellt. In der Western-Blot-Analyse konnte in Thymus, Gehirn und Ovar, in denen nur HASHsoma $(2.6 \mathrm{~Kb})$ exprimiert ist, eine Bande von $53 \mathrm{KDa}$ detektiert werden. Im Testisextrakt wurde ebenfalls nur eine 53 KDa große Bande detektiert, obwohl drei HASHTranskripte in Testis nachweisbar sind.

6. Durch Screenen einer Human-P1-Bibliothek mit der cDNA-Sonde (H-800) der Maus wurde ein humaner HASH-Klon isoliert. Mit Hilfe der Fluoreszenz-in situ-Hybridisierung (FISH) wurde das HASH-Gen des Menschen auf Chromosom 1p32-35 kartiert.

7. Es wurde im Rahmen sehr zeitaufwendiger Experimente versucht, eine Knock-out Maus für das HASH-Gen zu erzeugen. Es konnten zwar Chimären erhalten werden, aber keine, die das mutierte HASH-Allel über die Keimbahn weitergeben. Hingegen trat der äußerst seltene Fall der Insertionsmaus auf: $\mathrm{HASH}^{\text {neo/neo }}$-Insertionsmäuse, die durch die Integration des Konstrukts innerhalb der 5'-flankierenden Region des Exons 3 entstanden sind, zeigten eine partielle Lethalität während der embryonalen Entwicklung. Bei den Embryonen mit der $\mathrm{HASH}^{\text {neo/neo }}$-Insertion war die Entwicklung des Kopfes stark gestört. Insbesondere war der Bereich des Prosencephalons stark reduziert. Alle geborenen $\mathrm{HASH}^{\text {neo/neo }}-\mathrm{Nachkommen}$ waren jedoch nach der Geburt lebensfähig und zeigten keine äußerlich erkennbaren Abnormalitäten oder Veränderungen in Kopf- und Körpergröße. Ebenso zeigten alle Tiere ein normales Paarungsverhalten. Der variable Phänotyp der embryonalen Lethalität bei der $\mathrm{HASH}^{\text {neo/neo }}$-Insertionsmutation hängt vom genetischen Hintergrund ab. 


\section{LITERATUR}

Adham, I. M., Klemm, U., Maier, W. M., Hoyer-Fender, S., Tsaousidou, S. and Engel, W. (1989). Molecular cloning of preproacrosin and analysis of its expression pattern in spermatogenesis. Eur J Biochem. 182(3), 563-568.

Adham, I. M., Nayernia, K. and Engel. W. (1997). Spermatozoa lacking acrosin protein show delayed fertilization. Mol. Reprod. Dev. 46, 370-376.

Aho, H. (1997). Zur Struktur und Expression zweier keimzellspezifischer Gene: MCS und HASH. Dissertation, Universität Göttingen.

Ausubel, F. M. (1992). Current protocols in molecular biology. Wiley \& Sons Inc, New York, USA.

Barth, A. K. and Wilson, S. W. (1995). Expression of zebrafish nk2.2 is influenced by sonic hedgehog/vertebrate hedgehog-1 and demarcates a zone of neuronal differentiation in the embryonic forebrain. Development. 121, 1755-1768.

Beato, M. (1989). Gene regulation by steroid hormones. Cell 56, 335-344.

Benton, W. D. and Davis, R. W. (1977). Screening lamdagt recombinant clones by hybridization to single plaques in situ. Science 196, 180-182.

Birnboim, F. and Doly, J. (1979). A rapid alkaline extraction procedure for screening recombinant plasmid DNA. Nuc. Acids Res. 7, 1512-1523.

Bodmer, R. (1993). The gene tinman is required for specification of the heart and visceral muscles in Drosophila. Development. 118, 719-729.

Boer, P. H., Adra, C. N., Lau, Y. F. and McBurney, M. W. (1987). The testis-specific phosphoglycerate kinase gene pgk-2 is a recruited retroposon. Mol Cell Biol. 7(9), 3107-3112. 
Bolivar, F. and Beckmann, K. (1979). Plasmids of Escherichia coli as cloing vectors. Methods Enzymol. 68, 245-260.

Bradley, A., Evans, M. J. Kaufman, M. H. and Robertson, E. (1984). Formation of germline chimeras from embryo-derived teratocarcinoma cell lines. Nature. 309, 255-256.

Breathnach, R. and Chambon, P. (1981). Organisation and expression of eukaryotic split genes coding for proteins. Ann. Rev. Biochem. 50, 349-383.

Breitbart, R. E. and Nadal-Ginard, B. (1987). Developmentally induced muscle-specific transfactors control the differential splicing of alternative and constitutive Troponin $\mathrm{T}$ exons. Cell. 49, 793-803.

Capecchi, M. R. (1989). Altering the genome by homologous recombination. Science. 244, 1288-1292.

Chien, A., Edgar, D. B. and Trela, J. M. (1976). Desoxyribonucleic acid polymerase from the extremely thermophile Thermus aquaticus. J. Bacteriol. 127, 1550.

Chomczynski, P. and Sacchi, N. (1987). Single-step method of RNA isolation by acid guanidinium thiocyanate-phenol-chloroform extraction. Analytical Biochemistry 162, 156159.

Chubb, C. Genetic Control of Spermatogenesis and Steroidgenesis; in „Cell and Molecular Biology of the Testis“, Hrsg. v. Desjardins, C. and Ewing, L. R.; Oxford Univ. Press, Oxford 1993, pp. 90-107.

Clermont, Y., Oko., R. and Hermo, L. (1992). Cell biology of mammalian spermatogenesis. In „Cell and molecular biology of the Testis“ Hrsg.: Ewing, L. and Desjardins, C., Oxford University Press, New York, 332-376.

Cohen, D. R., Vandermark, S. E., McGovern, J. D. and Bradley, M. P. (1993). Transcriptional regulation in the testis: a role for transcription factor AP-1 complexes at various stages of 
spermatogenesis. Oncogene 8, 443-455.

Cruzalegui, F. H., Cano, E. and Treisman, R. (1999). ERK activation induces phosphorylation of Elk-1 at multiple S/T-P motifs to high stoichiometry. Oncogene 18, 79487957.

Dagert, M. and Ehrlich, S.D. (1979). Prolonged incubation in calcium chloride improves the competence of Escherichia coli cells. Gene 6, 23-28.

Doetschman, T., Gregg, R. G., Maeda, N. Hooper, M. L., Melton, D. W., Thompson, S. and Smithies, O. (1987). Targeted correction of a mutant HPRT gene in mouse embryonic stem cells. Nature. 330, 576-578.

Domenjoud, L., Nussbaum, G., Adham, I. M., Greeske, G. and Engel, W. (1990). Genomic sequences of human protamines whose genes, PRM1 and PRM2, are clustered. Genomics 8, 127-133.

Echelard, Y., Epstein, D. J., St-Jacqes, B., Shen, L., Mohler, J., McMahon, J. A. and McMahon, A. P. (1993). Sonic hedgehog, amember of a family of putative signaling molecules, is implicated in the regulation of CNS polarity. Cell. 75, 1417-1430.

Eddy, E. M., Welch, J. E. and O’Brien, D. A. (1993). Gene expression during spermatogenesis. In „Molecular Biology of the Male Reproductive System“ (D. de Kretser. Ed.). Academic Press, San Diego, CA. pp. 181-232.

Ehlers, M. R., Fox, E. A., Strydom, D. J. and Riordan, J. F. (1989). Molecular cloning of human testicular angiotensin-converting enzyme: the testis isozyme is identical to the Cterminal half of endothelial angiotensin-converting enzyme. Proc Natl Acad Sci 86(20), 7741-7745.

Ekker, S. C., Ungar, A. R., Greenstein, P., von Kessler, D. P., Porter, J. A., Moon, R. T. and Beachy, P. A. (1995). Patterning activity of vertebrate hedgehog proteins in the developing eye and brain. Curr. Biol. 5, 944-955. 
Engel, U., Beug, H., LaVail, J. H., Zenke, M. W., Mayo, K., Leonard, M. W., Foley, K. P., Yanag, Z., Kornhauser, J. M., Ko L. J., Lim, K.-C., George, K. M. and Breigel, K. (1992). Cis and trans regulation of tissue-specific transcription. J. Cell Sci. 16(Suppl.), 21-31.

Evans, M. J., and Kaufman, M. H. (1981). Establishment in culture of pluripotential cells from mouse embryos. Nature 292, 154-156.

Evans, S. M., Yan, W., Murillo, M. P., Ponce, J., and Papalopulu, N. (1995). tinman, a Drosophila homeobox gene required for heart and visceral mesoderm specification, may be represented by a family of genes in vertebrates: XNkx-2.3, a second vertebrate homologue of tinman. Development. 121, 3889-3899.

Fawcett, D. W. (1979). The cell biology of gametogenesis in the male. Perspect Biol Med. 22, $56-73$.

Feinberg, A. P., and Vogelstein, B. (1983). A technique for radiolabeling DNA restriction endonuclease fragments to high specific activity. Anal. Biochem. 132, 6-13.

Frischauf, A. M., Lehrach, H., Poutska, A. and Murray, N. (1983). Lamda replacement vectors carrying polylinker sequences. J. Mol. Biol. 170, 827-842.

Frischer, L. E., Hagen, F. S. and Garber, R. L. (1986). An inversion that disrupt the Antennapedia gene causes abnormal structure and localization of RNAs. Cell. 47, 1017-1023.

Gaspar, M. L., Meo, T., Bourgarel, P., Guenet, J. L. and Tosi, M. (1991). A single base deletion in the Tfm androgen receptor gene creates a short-lived messenger RNA that directs internal translation initiation. Proc Natl Acad Sci. 88, 8606-8610.

Geng, Y. and Johnson L. F. (1993). Lack of an initiator element is responsible for multiple transcriptional initiation sites of the TATA-less mouse thymidylate synthase promoter. Mol Cell Biol. 13, 4894-4903.

George, K. M., Leonard, M. W., Roth, M. E., Lieuw, K. H., Kioussis, D., Grosveld, F., and Engel, J. D. (1994). Embryonic expression and cloning of the murine GATA-3 gene. 
Development. 120, 2673-2686.

Gold, B. and Hecht, N. B. (1981). Differential compartimentalization of messenger ribonucleic acid in murine testis. Biochemistry. 20, 4871-4877.

Goodrich, J. A., Cutler, G. and Tjian, R. (1996). Contacts in context: promoter specificity and macromolecular interactions in transcription. Cell. 84, 825-830.

Gossler, A., Doetschman, T., Korn, R., Serfling, E. and Kemler, R. (1986). Transgenesis by means of blastocyst-derived embryonic stem cell lines. Proc. Natl. Acad. Sci. USA. 83, 90659069.

Gubler, U. and Hoffman, B. J. (1983). A simple and very efficient method for generating complimentary DNA libraries. Gene. 25, 263-269.

Hanahan, D., and Meselson, M. (1980). Plasmid screening at high colony density. Gene. 10, 63-67.

Hanahan, D. (1985). Techniques for transformation of E. coli. In: DNA cloning a practical approach. Glover, D. M. (Hrsg.), IRL Press, Oxford-Washington D. C.

Harvey, R. (1996). Nkx-2 homeobox genes and heart development. Dev Biol. 178, 203-216.

Hasty, P., Rivera-Perez, C., Chang, N. and Bradley, A. (1991). Target frequency and integration pattern for insertion and replacement vectors in embryonic stemm cells. Mol. Cell Biol. 11, 4509-4517.

Hatta, K. and Takeichi, M. (1986). Expression of N-cadherin adhesion molecules associated with early morphogenetic events in chick development. Nature. 320, 447-449.

Hecht, N. B. (1990). Regulation of „haploid expressed genes“ in male germ cells. J. Reprod. Fert. 88, 679-693.

Hecht, N. B. (1993) Gene expression during male germ cell development. In „Cell and 
Molecular Biology of the Testis“ (C. Desjardins and L. L. Ewing, Eds.). Oxford Univ. Press, New York, NY. pp400-432.

Hecht, N. B. (1998). Molecular mechanisms of male germ cell differentiation. BioEssays. 20, $555-561$.

Helfman, D. M., Cheley, S., Kuismanen, E., Finn, L. A. and Yamawaki-Kataoka, Y. (1986). Nonmuscle and muscle tropomyosin isoforms are expressed from a single gene by alternative RNA splicing and polyadenylation. Mol. Cell Biol. 6, 3582-3595.

Hentges, K., Thompson, K. and Peterson, A. (1999). The flat-top gene is required for the expansion and regionalization of the telencephalic primordium. Development. 126(8), 16011609.

Hirokawa, T., Boon-Chieng, S. and Mitaku, S. (1998). SOSUI: Classification and Secondary Structure Prediction System for Membrane Proteins. Bioinformatics. 14, 378-379.

Hogan, B., Constantini, F. and Lacy, E. (1994). Manipulating the mouse embryo. A Laboratory manual. $2^{\text {nd }}$ ed. Cold Spring Harbor Laboratory, Cold Spring Harbor, New York, USA.

Howard, T. E., Shai, S. Y., Langford, K. G., Martin, B. M. and Bernstein, K. E. (1990). Transcription of testicular angiotensin-converting enzyme (ACE) is initiated within the 12th intron of the somatic ACE gene. Mol Cell Biol. 10(8), 4294-4302.

Husain, I., Tomkinson, A. E., Burkhart, W. A., Moyer, M. B., Ramos, W., Mackey, Z. B., Besterman, J. M. and Chen J. (1995) Purification and characterization of DNA ligase III from bovine testes. Homology with DNA ligase II and vaccinia DNA ligase. J Biol Chem. 270, 9683-9690.

Ikeya, M., Lee, S. M. K., Johnson, J. E., McMahon, A. P. and Takada, S. (1997). Wnt signaling required for expansion of neural crest and CNS progenitors. Nature 389, 966-970.

Jiang, Y. and Evans, T. (1996). The Xenopus GATA-4/5/6 genes are associated with cardiac 
specification and can regulate cardiac-specific transcription during embryogenesis. Dev. Biol. $174,258-270$.

Johnson, P. A., Bunick, D. and Hecht, N. B. (1991). Protein binding regions in the mouse and rat protamine-2 genes. Biol. Reprod. 44, 127-134.

Johnson, R. L., Laufer, L., Riddle, R. D. and Tabin, C. (1994). Ectopic expresseion of sonic hedgehog alters dorsal-ventral patterning of somites. Cell. 79, 1165-1173.

Jones, N. C., Rigby, P. W. J. and Ziff, E. B. (1988). Trans-acting protein factors and the regulation of eukaryotic transcription: lessons from studies of DNA tumor viruses. Genes. Dev. 2, 267-281.

Joyner, A. (1993). Gene Targeting: A practical Approach. Oxford University Press, New York.

Kashiwabara, S., Baba, T., Takada, M., Watanabe, K., Yano, Y. and Arai, Y. (1990). Primary structure of mouse proacrosin deduced from the cDNA sequence and its gene expression during spermatogenesis. J Biochem 108(5), 785-791.

Kaufmann, T. C., Seeger, M. A. and Olsen, G. (1990). Molecular and genetic organization of the Antennapedia gene complex of Drosophila melanogaster. Adv. Genet. 27, 309-362.

Keime, S. (1993). Die 5'-nichttranslatierte Region des Proakrosingens der Ratte: DNAProtein-Interaktionen und partielle cDNA Klone für zwei potentielle DNA-bindende Proteine. Dissertation, Universität Göttingen.

Kelley, C., Blumberg, H., Zon, L. I. and Evans, T. (1993). GATA-4 is a novel transcription factor expressed in endocardium of the developing heart. Development. 118, 817-827.

Kihara, D., Shimizu, T. and Kanehisa, M. (1998). Prediction of Membrane Proteins Based on Classification of Transmembrane Segments. Protein Engineering. 11, 961-970.

Kim, Y., Kremling, H., Tessmann, D. and Engel, W. (1992). Nucleotide sequence and exon- 
intron structure of the bovine transition protein 1 gene. DNA Seq. 3(2), 123-125.

Kleene, K. C., Distel, R. J. and Hecht, N. B. (1984). Translational regulation and deadenylation of a protamine mRNA during spermatogenesis in the mouse. Dev. Biol. 105, 71-79.

Kleene, K. C. and Flynn, J. F. (1987). Characterization of a cDNA clone encoding a basic protein, TP2, involved in chromatin condensation during spermiogenesis in the mouse. J. Biol. Chem. 262, 17272-17277.

Kleene, K. C. (1989). Poly(A) shortening accompanies the activation of translation of five mRNAs during spermiogenesis in the mouse. Development. 106, 367-373.

Kleene, K. C. (1993). Multiple controls over the efficiency of translation of the mRNAs encoding transition proteins, protamines, and the mitochondrial capsule selenoprotein in late spermatids in mice. Dev Biol. 159(2), 720-731.

Kogan, S. C., Doherty, M. and Gitschier, J. (1987). An improved method for prenatal diagnosis of genetic diseases by analysis of amplified DNA sequences. N. Engl. J. Med. 317, 985-990.

Koshimizu, U., Watanabe, D., Tajima, Y and Nishimune, Y. (1992). Effects of W (c-kit) gene mutation on gametogenesis in male mice: agametic tubular segments in $\mathrm{W}^{\mathrm{f}} / \mathrm{W}^{\mathrm{f}}$ testes. Development. 114, 861-867.

Kozak, M. (1984). Compilation and analysis of sequences upstream from the translational start site in eukaryotic mRNAs. Nucleic Acids Res. 12, 857-872.

Kozak, M. (1989). The scanning model for translation: An update. J. Cell Biol. 108, 229-241.

Krauss, S., Concordet, J. P. and Ingham, P. W. (1993). A functionally conserved homolog of the Drosophila segment polarity gene hedgehog is expressed in tissues with polarizing activity in zebrafish embryos. Cell. 75, 1431-1444. 
Kremling, H., Luerssen, H., Adham, I. M., Klemm, U., Tsaousidou, S. and Engel, W. (1989). Nucleotide sequences and expression of cDNA clones for boar and bull transition protein 1 and its evolutionary conservation in mammals. Differentiation. 40(3), 184-190.

Kremling, H., Keime, S., Wilhelm, K., Adham, I. M., Hameister, H. and Engel, W. (1991). Mouse proacrosin gene: nucleotide sequence, diploid expression, and chromosomal localization. Genomics. 11(4), 828-834.

Laird, P. W., Zijderwald, A., Linders, K., Rudnicki, M. A., Jaenisch, R. and Berns, A. (1991). Simplified mammalian DNA isolation procedure. Nuc. Acids Res. 19, 4293.

Laverriere, A. C., NacNeill, C., Mueller, C., Poelmann, R. E., Burch, J. B. E. and Evans, T. (1994). GATA-4/5/6: A subfamily of three transcription factors expressed in developing heart and gut. J. Biol. Chem. 269, 23177-23184.

Le Douarin, N. M. and Kalcheim, C. (1999). The Neural Crest. New York. Cambridg Univ. Press. Second Edition.

Lee, K. J. and Jessell, T. M. (1999). The specification of dorsal cell fates in the vertebrate central nervous system. Ann. Rev. Neurosci. 22, 261-294.

Lewin, B. (1990). Gene IV. Cell Press, Cambridge.

Locker, J. and Buzard, G. (1990). A dictionary of transcription control sequences. DNA Seq. $1,3-11$.

Luerssen, H., Maier, W. M., Hoyer-Fender, S. and Engel, W. (1989). The nucleotide sequence of rat transition protein 2 (TP2) cDNA. Nucleic Acids Res. 17, 3585.

Maity, S. N. and de Crombrugghe, B. (1998). Role of the CCAAT-binding protein CBF/NF$\mathrm{Y}$ in transcription. Trends Biochem Sci. 23, 174-178.

Maniatis, T., Fritsch, E. F. and Sambrook, J. (1982). Molecular Cloning: A Laboratory Manual, Cold Spring Harbour, New York, USA. 
Maniatis, T., Goodbourn, S. and Fisher, J. A. (1987). Regulation of inducible and tissue specific gene expression. Science 236, 1237-1245.

Margolis, R. L., McInnis, M. G., Rosenblatt, A. and Ross, C. A. (1999). Trinucleotide repeat expansion and neuropsychiatric disease. Arch Gen Psychiatry. 56, 1019-1031.

Martin, G. R. (1981). Isolation of a pluripotent cell line from early embryos cultured in medium conditioned by teratocarcinoma stem cells. Proc. Natl. Acad. Sci. USA. 78, 76347638.

Medford, R. M., Nguyen, H. T., Destree, A. T., Summers, E. and Nadal-Ginard, B. (1984). A novel mechanism of alternative RNA splicing for the developmentally regulated generation of troponin T isoforms from a single gene. Cell. 38, 409-421.

Melton, D. W. (1994). Gene targeting in the mouse.Bioessays 16(9), 633-638.

Mettus, R. V., Litvin, J., Wali, A., Toscani, A. Latham, K., Hatton, K. and Reddy, E. P. (1994). Murine A-myb: evidence for differential splicing and tissue-specific expression. Oncogene. 9, 3077-3086.

Mitchell, P. J. and Tijian, R. (1989). Transcriptional regulation in mammalian cells by sequence-specific DNA binding proteins. Science 245, 371-378.

Moens, C. B., Auerbach, A. B., Conlon, R. A., Joyner, A. L. and Rossant, J. (1992). A targeted mutation reveals a role for $\mathrm{N}$-myc in branching morphogenesis in the embryonic mouse lung. Genes Dev. 6, 691-704.

Moutier, R. (1976). New mutations causing sterility restricted to the male in rats and mice. In: The Laboratory Animal in the Study of Reproduction (Antikatziedes, T. H., Erichsen, S. and Spiegel, A. Eds.). Gustav Fischer Verlag, Stuttgart, 115-117.

Müller, F., Chang, B. E. Albert, S., Fischer, N., Tora, L. and Strähle, U. (1999). Intronic enhancers control expression of zebrafish sonic hedgehogin floor plate and notochord. 
Development. 126, 2103-2116.

Murray, N. E., Brammer, W. J. and Murray, K. (1977). Lambda phages that simplify the recovery of in vitro recombinants. Mol. Gen. Genet. 150, 53-56.

Nakagawa, S. and Takeichi, M. (1995). Neural crest cell-cell adhesion controlled by sequential and subpopulation-specific expression of novel cadherins. Development. 121, $1321-1332$.

Nakai, K. and Horton, P. (1999). PSORT: a program for detecting sorting signals in proteins and predicting their subcellular localization. Trends Biochem Sci. 24, 34-36.

Nardelli, J., Thiesson, D., Fujiwara, Y., Tsai, F. Y. and Orkin, S. H. (1999) Expression and genetic interaction of transcription factors GATA-2 and GATA-3 during development of the mouse central nervous system. Dev Biol. 210, 305-321.

Newman, C. S., and Krieg, P. A. (1998). Tinman-related genes expressed during heart development in Xenopus. Dev. Genet. 22, 230-238.

Nieto, M. A., Sargent, M. G., Wilkinson, D. G. and Cooke, J. (1994). Control of cell behavior during vertebrate development by slug, a zinc finger gene. Science. 264, 835-839.

Norander, J. Kempe, T., and Messing, J. (1983). Constuction of improved M13 vectors using oligonucleotide-directed mutagenesis. Gene 26, 101-161.

Oppi, C., Shore, S. K. and Reddy, E. P. (1987). Nucleotide sequence of testis-derived c-abl cDNAs: implications for testis-specific transcription and abl oncogene activation. Proc Natl Acad Sci. 84(23), 8200-8204.

Oyen. O., Myklebust, F., Scott, J. D., Cadd, G. G., McKnigt, G. S., Hansson, V. and Jahnsen, T. (1990). Subunits of cAMP proteinkinase show differential and distinct expression patterns during germ cell line differentiation: Alternative polyadenylation in germ cells gives rise to unique smaller-sized mRNA species. Biol. Reprod. 43, 46-54. 
Pabst, O., Herbrand, H., Takuma, N. and Arnold, H. H. (2000). Nkx2 gene expression in neuroectoderm but not in mesendodermally derived structures depends on sonic hedgehog in mouse embryos. Dev Genes Evol. 210, 47-50.

Pryor, I. L., Xu, W. and Hamilton, D. W. (1992). Immunodetection after complete destaning of coomassie blue-stained proteins on Immobilon-PVDF. Analy. Bioch. 202, 100104.

Ptashne, M. and Gann, A. A. F. (1990). Activators and targets. Nature 346, 329-331.

Quandt, K., Frech, K., Karas, H., Wingender, E. and Werner, T. (1995). MatInd and MatInspector - New fast and versatile tools for detection of consensus matches in nucleotide sequence data. Nucleic Acids Research. 23, 4878-4884.

Qvist, H., Sjostrom, H. and Noren, O. (1998). The TATA-less, GC-rich porcine dipeptidylpeptidase IV (DPPIV) promoter shows bidirectional activity. Biol Chem. 379, 7581

Rapp, G., Klaudiny, J., Hagendorff, G., Luck, M. R. and Scheit, K. H. (1989). Complete sequence of the coding region of human elongation factor 2 (EF-2) by enzymatic amplification of cDNA from human ovarian granulosa cells. Biol. Chem. Hoppe-Seyler. 370, 1071-1075.

Robertson, E., Bradley, A. Kuehn, M. and Evans, M. (1986). Germline transmission of genes introduced into cultured pluripotential cells by retroviral vectors. Nature. 323, 445-448.

Rubenstein, J. L. R. and Shimamura, K. (1998). Regionalization of the prosencephalic neural plate. Ann. Rev. Neurosci. 21, 445-477.

Russell, L. D. Barriers to Entry of Substances into Seminiferous Tubules: Compatibility of Morphological and Physiological Evidence. In „, Banbury Report 34: Biology of Mammalian Germ Cell Mutagenesis“, Hrsg. v. Allen, J. W., Bridges, B. A., Lyon, M. F., Moses M. J. and Russell L. D.; Cold Spring Harbor Laboratory, New York 1990, pp. 3-17. 
Saiki, R. K., Scharf, S., Faloona, F., Mullis., K. B., Horn., G. T. Erlich, H. A. and Arnheim, N. (1885). Enzymatic Amplification of beta-globin genomic sequences and restriction site analysis for diagnosis of sickle cell anemia. Science 230, 1350-1354.

Sambrook, J., Fritsch, E. F. and Maniatis, T. (1989). In "Molecular cloning: A Laboratory manual". $2^{\text {nd }}$ ed. Cold Spring Harbor, New York, USA.

Sanger, F., Nicklen, S. and Coulson, A. R. (1977). DNA sequencing with chainterminating inhibitors. Proc. Natl. Acad. Sci. USA. 74, 5463-5467.

Schäfer, M., Nayernia, K., Engel, W. and Schäfer, U. (1995). Translational control in spermatogenesis. Devel. Biol. 172, 344-352.

Schorle, H., Meier, P., Buchert, M., Jaenisch, R. and Mitchell, P. J. (1996). Transcription factor AP-2 essential for cranial closure and craniofacial development. Nature. 381, 235-238.

Schlüter, G., Kremling, H. and Engel, W. (1992). The gene for human transition protein 2: nucleotide sequence, assignment to the protamine gene cluster, and evidence for its low expression. Genomics. 14(2), 377-383.

Shamsadin, A. R. (1995). Zur Struktur eines Gens, dessen Produkt an der Regulation des Proakrosingens beteiligt ist. Diplomarbeit, Universität Göttingen.

Sheets, M. D., Ogg, S. C. and Wickens, M. P. (1990). point mutations in AAUAAA and the poly(A) addition site: effects on the accuracy and efficiency of cleavage and polyadenylation in vitro. Nucleic Acids Res. 18, 5799-5805.

Shen, W.-F., Detmer, K., Simonitch-Eason, T. A., Lawrence, H. J. and Largman, C. (1991). Alternative splicing of the HOX 2.2 homeobox gene in human hematopoietic cells and murine embryonic and adult tissues. Nucleic Acids Res. 19, 539-545.

Sidman, R. L., Dickie, M. M. and Apple, S. H. (1964). Mutant mice (quaking and jimpy) with deficient myelination in the central nervous system. Science. 144, 309-312. 
Smith, C. W. J., Patton, J. G. and Nadal-Ginard, B. (1989). Alternative splicing in the control of gene expression. Annu. Rev. Genet. 23, 527-577.

Sorrentino, V., Giorgi, M., Geremia, R., Besmer, P. and Rossi, P. (1991). Expression of the ckit proto-oncogene in the murine male germ cells. Oncogene. 6, 149-151.

Southern, E. M. (1975). Determination of specific sequences among DNA fragments seperated by gel electrophoresis. J. Mol. Biol. 98, 503-517.

Stern, L., Gold, B. and Hecht, N. B. (1983). Gene expression during mammalian spermatogenesis. I. Evidence for stage-specific synthesis of polypeptides in vivo. Biol Reprod. 28, 483-496.

Tanaka, M., Kasahara, H., Bartunkova, S., Schinke, M., Komuro, I., Inagaki, H., Lee, Y., Lyons, G. E. and Izumo, S. (1998). Vertebrate homologs of tinman and bagpipe: Roles of the homeobox genes in cardiovascular development. Dev. Genet. 22, 239-249.

Tang. W and Tseng, H. (1999). A GC-rich sequence within the 5'-untranslated region of human basonuclin mRNA inhibits its translation. Gene. 237, 35-44.

Thomas, K. R. and Cappechi, M. R. (1987). Site-directed mutagenesis by gene targeting in mouse embryo-derived stem cells. Cell. 51, 503-512.

Tonissen, K. F., Drysdale, T. A., Lints, T., Harvey, R. P. and Krieg, P. A. (1994). Xnkx-2.5, a Xenopus gene related to $\mathrm{Nkx}-2.5$ and tinman: Evidence for a conserved role in cardiac development. Dev. Biol. 162, 325-328.

Tremblay, P., Kessel, M. and Gruss, P. (1995). A transgenic neuroanatomical marker identifies cranial neural crest deficiencies associated with the Pax3 mutant splotch. Dev. Biol. 171, 317-329.

Truett, G. E., Jacob, H. J., Miller, J., Drouin, N., Smoller, J. W., Lander, E. S. and Leibel R. L. (1995). Genetic map of rat chromosome 5 including the fatty (fa ) locus. Mammal Genome. 6, 25-30. 
Tsai, F.-Y., Keller, G., Kuo, F. C., Weiss, M., Chen, J., Rosenblatt, M., Alt, F. W., and Orkin, S. H. (1994). An early hematopoietic defect in mice lacking the transcription factor GATA-2. Nature 371, 221-226.

Tybulewicz, V. L. J., Crawford. C. E., Jackson, P. K. Bronson, R. T. and Mulligan, R. C. (1991). Neonatal lethality and lymphopenia in mice with a homozygous disruption of the cabl proto-oncogene. Cell. 65, 1153-1163.

Wilkinson, D. and Nieto, A. M. (1993). In „Guide to techniques in mouse development“, Academic Press, New York, pp 361-372.

Wilson, K. and Ashworth, A. (1987). Mammalian spermatogenic gene expression. Trends in Genet. 3, 351-355.

Wirth, T., Staudt, L. and Baltimore, D. (1987). An octamer oligonucleotide upstream of TATA-motif is sufficient for lymphoid-specific promoter activity. Nature 329, 174-178.

Yamada, J., Kuramoto, T. and Serikawa, T. (1994). A rat genetic linkage map and comparative maps for mouse or human homologous rat genes. Mamm. Genome. 5, 63-83.

Yoshinaga, K., Nishikawa, S., Ogawa, M., Hayashi, S., Kunisada, T., Fujimoto, T. and Nishikawa, S. (1991). Role of c-kit in mouse spermatogenesis: identification of spermatogonia as a specific site of c-kit expression and function. Development. 113, 689-699.

Young, R. A. and Davis, R. W. (1983). Efficient isolation of genes by using antibody probes. Proc. Natl. Acad. Sci. USA 80, 1194-1198.

Zhang, J., Hagopian-Donaldson, S., Serbedzija, G., Elsemore, J., Plehn-Dujowich, D., McMahon, A. P., Flavell, R. A. and Williams, T. (1996). Neural tube, skeletal and body wall defects in mice lacking transcription factor AP-2. Nature. 381, 238-241. 


\section{ANHANG}

\section{Sequenzen der verwendeten Oligonukleotide}

\begin{tabular}{|c|c|c|c|c|c|c|c|}
\hline $\mathrm{HA} 7$ & $\mathrm{CTT}$ & AGA & $\mathrm{CCA}$ & GAA & ATC & CTC & CTC \\
\hline HA 15 & GGA & $\mathrm{GCT}$ & TTG & $\mathrm{AAA}$ & $\mathrm{GTT}$ & CTG & GAG \\
\hline HA 25 & GTG & TTC & $\mathrm{ACC}$ & $\mathrm{TCC}$ & AAA & CTG & TGA \\
\hline $\mathrm{HA} 42 \mathrm{R}$ & $\mathrm{CAA}$ & ATG & GAA & AGA & GCC & $\mathrm{ACG}$ & CGG \\
\hline HA 71 & $\mathrm{ACC}$ & $\mathrm{ACA}$ & $\mathrm{TCT}$ & $\mathrm{CCA}$ & GGG & $\mathrm{TCT}$ & CAC \\
\hline $\mathrm{HA} 723 \mathrm{P} 2$ & ATG & $\mathrm{CCG}$ & AAG & TGA & AGG & CGC & TGC \\
\hline $\mathrm{HO} 1$ & AGG & $\mathrm{AGA}$ & TGC & TAA & $\mathrm{GTT}$ & GTG & TGG \\
\hline $\mathrm{HO} 2$ & AGG & GAC & AGG & GAG & GAG & $\mathrm{ATG}$ & AGG \\
\hline HO3 & GCA & CAG & $\mathrm{CTT}$ & GAG & $\mathrm{TAT}$ & GAT & $\mathrm{ACA}$ \\
\hline $\mathrm{HO} 4$ & GAG & GAA & $\mathrm{ATC}$ & GTA & GGC & TGT & TCG \\
\hline HO5 & GTA & $\mathrm{TCT}$ & GTG & $\mathrm{TGT}$ & TTG & GCC & \\
\hline HO 6 & GTG & $\mathrm{GCT}$ & GGG & $\mathrm{ACA}$ & $\mathrm{CAT}$ & TGT & GTC \\
\hline $5 \mathrm{H} 1$ & GCA & $\mathrm{TTT}$ & $\mathrm{TAA}$ & GGG & GTA & TGG & TTG \\
\hline $5 \mathrm{H} 2$ & GGA & AGG & $\mathrm{GCT}$ & GAT & TGG & TTT & TAG \\
\hline HO 7 & CGC & $\mathrm{GCT}$ & CAG & CTG & $\mathrm{CTG}$ & TTC & \\
\hline HO8 & GGA & GGG & $\mathrm{ACC}$ & $\mathrm{CCG}$ & $\mathrm{GCC}$ & CTC & \\
\hline HO9 & GCC & $\mathrm{TTC}$ & $\mathrm{ACC}$ & TTC & GGC & ATC & \\
\hline HO1O & TCC & $\mathrm{TCT}$ & $\mathrm{CTA}$ & CGG & $\mathrm{TTT}$ & GTG & G \\
\hline HO11 & GAG & $\mathrm{ACA}$ & CAG & AGC & TGA & TAG & \\
\hline HO12 & $\mathrm{CTT}$ & $\mathrm{CTT}$ & $\mathrm{CCC}$ & $\mathrm{ACT}$ & $\mathrm{TTC}$ & $\mathrm{CTT}$ & TGC \\
\hline H5F 1 & $\mathrm{CTT}$ & $\mathrm{ACC}$ & $\mathrm{ATT}$ & CAG & $\mathrm{CTC}$ & CAG & TTG \\
\hline H5R1 & CTG & AGT & GCG & $\mathrm{GCA}$ & CTT & $\mathrm{CCT}$ & TGA \\
\hline H5R2 & GTC & TAA & $\mathrm{TCA}$ & $\mathrm{CAA}$ & ATG & GAG & $\mathrm{GCT}$ \\
\hline $\mathrm{H} 3 \mathrm{~F} 1$ & $\mathrm{CAG}$ & ATG & $\mathrm{TTC}$ & $\mathrm{ACT}$ & GAG & TAA & CAG \\
\hline H3R1 & $\mathrm{CAT}$ & $\mathrm{TCA}$ & TGG & $\mathrm{TCT}$ & CTC & CTA & GTG \\
\hline $\mathrm{HE} 11 \mathrm{R} 1$ & CAC & ATA & $\mathrm{AAT}$ & GTC & TTG & $\mathrm{CAT}$ & GAG \\
\hline $\mathrm{HE} 12 \mathrm{~F} 1$ & GAG & AGA & GAC & $\mathrm{CCA}$ & GAG & AGA & GAA \\
\hline $\mathrm{HE} 12 \mathrm{R} 1$ & CTA & TAT & TCA & GGG & $\mathrm{TCA}$ & CTG & $\mathrm{TCA}$ \\
\hline
\end{tabular}




\begin{tabular}{|c|c|c|c|c|c|c|c|c|}
\hline H5R1 & CGA ATA & GGC & ATT & I GGC & $\mathrm{TTC}$ & $\therefore$ GG & & \\
\hline $5 \mathrm{H} 3$ & $\mathrm{CAT} \mathrm{CCA}$ & $\mathrm{CCT}$ & GTG & $\mathrm{G} T \mathrm{TC}$ & $A G C$ & $\mathrm{G} \mathrm{GA}$ & $A C$ & \\
\hline $\mathrm{H} 1$ & $\mathrm{GCA} \quad \mathrm{CCA}$ & AGC & TTA & $A \mathrm{AAI}$ & [ CTI & $\Gamma \mathrm{AG}$ & GG & \\
\hline $3 \mathrm{HR}$ & CAG GGA & $A A T$ & CAA & $A \mathrm{GAC}$ & $\therefore \mathrm{ACI}$ & $\Gamma \mathrm{TT}^{\prime}$ & IT $\mathrm{C}$ & \\
\hline $3 \mathrm{H} 5 \mathrm{f} 1$ & $\mathrm{GAC} C A A$ & CGT & GGG & $\mathrm{G} A \mathrm{AG}$ & $A$ AGC & & & \\
\hline H $5 r 1$ & $\mathrm{CAT} \mathrm{CAG}$ & GTC & ATT & $\Gamma \mathrm{TTC}$ & $\mathrm{TTC}$ & & & \\
\hline eo3 & $\mathrm{CCT} \mathrm{TCT}$ & ATC & GCC & $\mathrm{C} \mathrm{TTC}$ & $\mathrm{TTC}$ & $\mathrm{A} \mathrm{AC}$ & $\mathrm{CG} \quad \mathrm{AG}$ & \\
\hline $1-1 F L$ & $(\mathrm{FL}) \mathrm{CT}$ & СTT & $\mathrm{CCT}$ & $\mathrm{TCC}$ & $\mathrm{TCT}$ & TCC & $\mathrm{C} \mathrm{TCT}$ & $\mathrm{C}$ \\
\hline $1-2 \mathrm{FL}$ & $(F L) G A$ & $\mathrm{CCT}$ & TAC & TTC & TAC & $\mathrm{TCT}$ & T TTG & G \\
\hline $3-1 F L$ & $(\mathrm{FL}) \mathrm{CT}$ & TGT & $\mathrm{CTT}$ & TCA & GCA & $\mathrm{CCA}$ & A CTC & $\mathrm{C}$ \\
\hline E3-2FL & $(\mathrm{FL}) \mathrm{GT}$ & GGC & TGG & GAC & $\mathrm{ACA}$ & $\mathrm{TTG}$ & $\mathrm{G}$ TGT & $\mathrm{C}$ \\
\hline E8-1FL & $(F \perp) G A$ & $\mathrm{AAT}$ & CGT & AGG & CTG & TTC & C GTA & G \\
\hline $\mathrm{E} 8-2 \mathrm{FL}$ & $(\mathrm{FL}) \mathrm{CT}$ & TCG & GAA & AGC & $\mathrm{TCA}$ & CAC & $\mathrm{C}$ ATC & $\mathrm{C}$ \\
\hline pe1 & $(\mathrm{FL}) \mathrm{CC}$ & $\mathrm{CAG}$ & CTA & $\mathrm{CAA}$ & $\mathrm{AAT}$ & $\mathrm{TCC}$ & $\mathrm{C} \mathrm{TCT}$ & $\mathrm{TCT} \mathrm{C}$ \\
\hline pe 2 & $(F L) C C$ & TGC & $\mathrm{TCC}$ & $\mathrm{TTT}$ & CTT & $\mathrm{TCC}$ & C $C A G$ & CTA C \\
\hline pe 3 & $(\mathrm{FL}) \mathrm{CG}$ & AGG & GAC & AGG & GAG & GAG & $\mathrm{G}$ ATG & AGG $\mathrm{I}$ \\
\hline pe 4 & $(F L) A A$ & GAC & GCG & GGC & CGG & GAC & C $\mathrm{GAG}$ & GGA $C$ \\
\hline
\end{tabular}

\section{Abkürzungen}

A

Abb.

APS

ATP

Bp

BSA

bzw.

cDNA

C

ca.

$\mathrm{Ci}$

cpm
Purinbase Adenin; Ampere

Abbildung

Ammoniumpersulfat

Adenosin-5-triphosphat

Basenpaare

Rinderserumalbumin

beziehungsweise

komplementäre DNA

Pyrimidinbase Cytosin

circa

Curie

"counts per minute"(Zählrate) 


\begin{tabular}{|c|c|}
\hline $\mathrm{Da}$ & Dalton \\
\hline dATP & Desoxyadenosintriphosphat \\
\hline $\mathrm{dCTP}$ & Desoxycytosintriphosphat \\
\hline $\mathrm{ddH}_{2} \mathrm{O}$ & bidestilliertes Wasser \\
\hline ddNTPs & Didesoxynucleotidtriphosphate \\
\hline DEAE & Diethylaminoethan \\
\hline DEPC & Diethylpyrocarbonat \\
\hline dGTP & Desoxyguanosintriphosphat \\
\hline DMSO & Dimethlsulfoxyd \\
\hline DNA & Desoxyribonukleinsäure \\
\hline DNase & Desoxyribonuklease \\
\hline dNTPs & Desoxynukleosidtriphosphate \\
\hline DTT & Dithiothreitol \\
\hline dTTP & Desoxythymidintriphosphate \\
\hline EDTA & Ethylendiamintetraessigsäure \\
\hline $\mathrm{g}$ & Erdbeschleunigung $\left(9,80665 \mathrm{~m} / \mathrm{sec}^{2}\right)$; Gramm \\
\hline $\mathrm{G}$ & Purinbase Guanin \\
\hline GET & Glukose EDTA Tris \\
\hline h & Stunde(n) \\
\hline HAc & Essigsäure \\
\hline hsv-tk & Herpes Simplex Virus Thymidin-Kinase \\
\hline IPTG & Isopropyl-ß-thiogalactopyranosid \\
\hline $\mathrm{kb}$ & Kilobasenpaare \\
\hline $\mathrm{kDa}$ & Kilodalton \\
\hline 1 & Liter \\
\hline LB & Luria Bertani \\
\hline LMP-Agarose & low melting point-Agarose \\
\hline Lsg. & Lösung \\
\hline $\mathrm{m}$ & milli \\
\hline M & Molar \\
\hline $\mathrm{mCi}$ & Millicurie \\
\hline MG & Molekulargewicht \\
\hline$\mu$ & mikro \\
\hline
\end{tabular}


$\mathrm{mM}$

mRNA

n

$\mathrm{N}$

OD

$\mathrm{p}$

PAGE

PCR

PEG

pfu

RNA

RNase

RNAsin

rRNA

RT

SDS

SSC

sec

$\mathrm{T}$

Tab.

TEMED

Tfm

TNP

Tris

t-RNA

$\mathrm{U}$

Upm

UV

V

Vol.

WT

X-Gal

z. B.
Millimolar

messenger RNA

nano

Normal

Optische Dichte

pico

Polyacrylamidgelelektrophorese

"Polymerase chain reaction"

Polyethylenglycoll

"plaque forming unit"

Ribonukleinsäure

Ribonuklease

Ribonukleaseinhibitor

ribosomale Ribonukleinsäure

Raumtemperatur

Natriumdodecylsulfat

Standard saline citrat

Sekunde

Pyrimidinbase Thymidin

Tabelle

Tetramethylethylendiamin

testikuläre Feminisierung

Transitionsprotein

Tris- (hydroxymethyl) aminomethan

transfer Ribonukleinsäure

Units (Einheit der Enzymaktivität)

Umdrehung pro Minute

ultraviolettes Licht

Volt

Volumen

Wildtyp

5-Brom-4-Chlor-3-Indolyl-ß-Galactosid

zum Beispiel 


\section{Symbole für Aminosäuren}

\begin{tabular}{|c|c|c|}
\hline$A$ & Ala & Alanin \\
\hline B & Asx & Aspargin oder Asparaginsäure \\
\hline $\mathrm{C}$ & Cys & Cystein \\
\hline $\mathrm{D}$ & Asp & Asparaginsäure \\
\hline $\mathrm{E}$ & Glu & Glutaminsäure \\
\hline $\mathrm{F}$ & Phe & Phenylalanin \\
\hline G & Gly & Glycin \\
\hline $\mathrm{H}$ & His & Histidin \\
\hline I & Ile & Isoleucin \\
\hline $\mathrm{K}$ & Lys & Lysin \\
\hline $\mathrm{L}$ & Leu & leucin \\
\hline $\mathrm{M}$ & Met & Methionin \\
\hline $\mathrm{N}$ & Asn & Asparagin \\
\hline $\mathrm{P}$ & Pro & Prolin \\
\hline$Q$ & Gln & Glutamin \\
\hline $\mathrm{R}$ & Arg & Arginin \\
\hline $\mathrm{S}$ & Ser & Serin \\
\hline $\mathrm{T}$ & Thr & Threonin \\
\hline $\mathrm{V}$ & Val & Valin \\
\hline W & $\operatorname{Trp}$ & Tryptophan \\
\hline $\mathrm{Y}$ & Tyr & Tyrosin \\
\hline $\mathrm{Z}$ & Glx & Glutamin oder Glutaminsäure \\
\hline
\end{tabular}




\section{Danksagung}

Als erstes danke ich Herrn Professor Dr. W. Engel für die Überlassung des interessanten Dissertationsthemas und seiner ständigen Bereitschaft zur ideellen und finanziellen Unterstützung. Ferner möchte ich Herrn Prof. Dr. W. Engel für die mühsame Durchsicht des Manuskriptes danken.

Besonders danke ich Dr. I. M. Adham für die hilfreichen Tips und anregenden Diskussionen, stete Unterstüzung und kompetente Betreuung dieser Arbeit.

Bei Rahman Shamsadin, Mahmoud Sallam und Radu Niculai möchte ich mich für die freundschaftliche Zusammenarbeit und Diskussionsbereitschaft herzlich bedanken.

Bei allen Mitarbeitern des Instituts für Humangenetik möchte ich mich für die freundliche Atmosphäre und die Hilfsbereitschaft bedanken.

Dem Graduiertenkolleg „Molekularegenetik der Entwicklung“ möchte ich für die finanzielle Unterstützng danken.

Abschließend möchte ich meiner Frau, meinem Sohn und meinen Eltern danken, die mir das Studium der Biologie in Deutschland ermöglichten und mich auch während dieser Arbeit bedingungslos und mannigfaltig unterstützt haben.

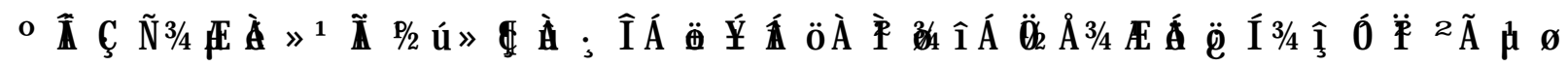

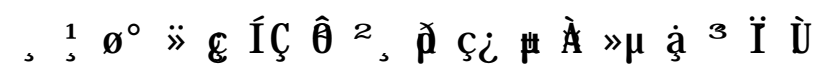

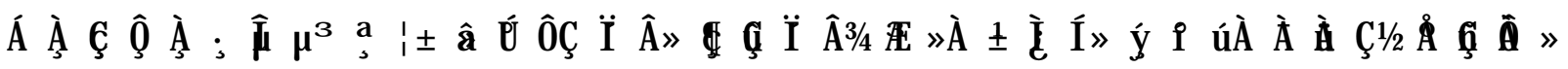

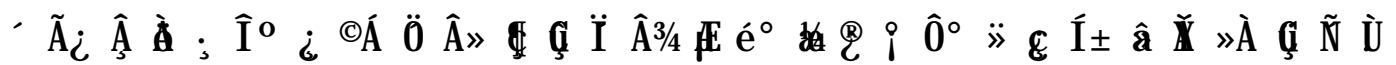




\section{Lebenslauf}

Persönliche Daten:

Name: $\quad$ Oh

Vorname: Changkyu

Geburtsdatum: 23. Sep. 1967

Geburtsort: Honsung, Korea

Familienstand: $\quad$ verheiratet seit April 1992, ein Sohn

Staatsangehörigkeit: koreanisch

03. 1995 - 09. 1996 Zivildienst anstelle des Wehrdienstes

Ausbildungsdaten:

03. 1973 - 02. $1979 \quad$ Besuch der Grundschule, Korea

03. 1979 - 02. $1985 \quad$ Besuch der Hauptschule (Gymnasium), Korea

03. 1985 - 02. 1989 Studium (Biologie) an der Universität Yonsei, Korea

10. 1989 - 09. 1990 Deutschkurs für ausländische Studenten an der GeorgAugust-Universität in Göttingen

11. 1990 - 10. $1994 \quad$ Hauptdiplom (Biologie) an der Friedrich-Alexander-Universität in Erlangen (Hauptfach: Biochemie)

10. 1993 - 10. $1994 \quad$ Diplomarbeit in der Gruppe von Prof. Dr. E. Schweizer am Institut für Biochemie, Erlangen

ab Dezember. 1996 Beginn der experimentellen Arbeiten zur vorliegenden Dissertation unter der Leitung von Prof. Dr. W. Engel im Rahmen des Graduiertenkollegs "Molekulare Genetik der Entwicklung" 